Prepared for the U.S. Department of Energy under Contract DE-AC05-76RL01830

\title{
Integrated Modeling and Decision- Support System for Water Management in the Puget Sound Basin: Snow Caps to White Caps
}

AE Copping
Z Yang
N Voisin
R Taira
M Wigmosta

${ }^{1}$ University of Washington

\footnotetext{
University of Washington
}

J Richey $^{1}$

T Wang

M Constans ${ }^{1}$

B Van Cleve

T Tesfa

December 2013

Pacific Northwest

NATIONAL LABORATORY

Proudly Operated by Battelle Since 1965 


\title{
DISCLAIMER
}

This report was prepared as an account of work sponsored by an agency of the United States Government. Neither the United States Government nor any agency thereof, nor Battelle Memorial Institute, nor any of their employees, makes any warranty, express or implied, or assumes any legal liability or responsibility for the accuracy, completeness, or usefulness of any information, apparatus, product, or process disclosed, or represents that its use would not infringe privately owned rights. Reference herein to any specific commercial product, process, or service by trade name, trademark, manufacturer, or otherwise does not necessarily constitute or imply its endorsement, recommendation, or favoring by the United States Government or any agency thereof, or Battelle Memorial Institute. The views and opinions of authors expressed herein do not necessarily state or reflect those of the United States Government or any agency thereof.

\author{
PACIFIC NORTHWEST NATIONAL LABORATORY \\ operated by \\ BATTELLE \\ for the \\ UNITED STATES DEPARTMENT OF ENERGY \\ under Contract DE-AC05-76RL01830
}

Printed in the United States of America
Available to DOE and DOE contractors from the
Office of Scientific and Technical Information,
P.O. Box 62, Oak Ridge, TN 37831-0062;
ph: (865) 576-8401
fax: $(865) 576-5728$
email: reports@adonis.osti.gov

Available to the public from the National Technical Information Service

5301 Shawnee Rd., Alexandria, VA 22312

ph: (800) 553-NTIS (6847)

email: orders@ntis.gov <http://www.ntis.gov/about/form.aspx>

Online ordering: http://www.ntis.gov

This document was printed on recycled paper. 


\section{Integrated Modeling and Decision- Support System for Water Management in the Puget Sound Basin: Snow Caps to White Caps}

$\begin{array}{ll}\text { AE Copping } & \text { J Richey }^{1} \\ \text { Z Yang } & \text { T Wang } \\ \text { N Voisin } & \text { M Constans }{ }^{1} \\ \text { R Taira } & \text { B Van Cleve } \\ \text { M Wigmosta } & \text { T Tesfa }\end{array}$

December 2013

Prepared for

the U.S. Department of Energy

under Contract DE-AC05-76RL01830

Pacific Northwest National Laboratory

Richland, Washington 99352

${ }^{1}$ University of Washington 



\section{Summary}

The Puget Sound basin and its complex bathymetry, topography, soils, rivers and climate support a rich array of life in the marine waters, the watersheds, and tributaries, and provides a prosperous and appealing home for millions of people. However, the integrity of the ecosystem, the viability of iconic species like salmon and orca, and the livelihood of the human residents are threatened by the twin forces of climate change and ever increasing pressure from human development.

The purpose of the Snow Caps to White Caps project is to provide data products and insight for water resource managers to support their predictions and management actions that address future changes in water resources (fresh and marine) in the Puget Sound basin. This report details the efforts of a team of scientists and engineers from Pacific Northwest National Laboratory (PNNL) and the University of Washington (UW) to examine the movement of water in the Snohomish basin, under conditions of future changes in climate and land use/land cover (LULC), using a set of linked numerical models. In consultation with water resource managers the research team developed a set of research and management questions to be tested with the output of an integrated model system that follows water from the top of the mountains through the watershed, across the floodplain, into the river slough, and into Puget Sound via Port Gardner Bay and Possession Sound. The use of an integrated modeling framework allowed the team to carry out model linkages, quality control, display, and archiving of the results in an organized manner.

This project will assist state and federal agencies, local governments, tribes, and other entities to work together effectively on Puget Sound agenda priority actions, filling a critical program implementation need by contributing to the region's understanding of anticipated climate change effects. This project has been made possible through generous support from the Environmental Protection Agency (EPA) Region X's Puget Sound Science and Technical Studies Assistance Program.

Watershed modeling suggests that for the Snohomish basin, future climate changes will have more effect on the waterflow rates at the downstream portion of the watershed that feeds into the floodplain and the estuary, than will changes in LULC. For individual subbasins, the pattern is more complex, with the sensitivity of waterflow tied closely to whether the subbasin is a rain/snow transition basin or a more raindominated subbasin. Changes in forestry practices in upper watershed basins affect subbasins differently, with some experiencing increased annual flow while others show changes in the timing of the hydrograph.

The hydrodynamics of water in the lower estuary and the floodplain are affected by the riverflow entering the Snohomish River mainstem and distributaries, and by ocean forcing of tides and winds. The extent of flooding in the floodplain and intertidal areas are affected by both future LULC and climate changes, as seen by the areal extent of flooding, the depth of flood waters, salinity of the floodwaters, and the furthest extent that tidal waters extend upstream in the river and distributary sloughs. Stormwater carrying fecal coliform bacteria was also examined as it is discharged into Port Gardner Bay by stormwater from the City of Everett.

The specific scenarios and outputs that depict future climate and LULC changes were designed in close coordination with local water resource managers in Snohomish and King counties and the City of 
Everett. The results of the study are being presented to interested parties at the state and local level, and extrapolation of the potential for applying the Snow Caps to White Caps methods beyond the Snohomish to other Puget Sound basins is under way. 


\section{Acknowledgments}

Our project team would like to acknowledge the help and advice we received from a large number of people throughout the region. We could not have carried out this project without the input from staff at Snohomish County Surface Water Management, particularly Tim Walls, Ann Bylin, Kathleen Herrmann, Debbie Terwilliger, David Ojala, Paul Marczin, Sheila Hagen, and Michael Rustay. Similarly staff at King County Department of Natural Resources and Parks were particularly helpful, including Janne Kaje, Randy Shuman, and Tom Georgianna. Jim Miller and Heather Kibbey at the City of Everett Public Works Department provided great input, as did Terry Williams, Joshua Kubo, and Abby Hook (Hook and Knauer, LLP) from the Tulalip Tribes.

This project was made possible thanks to a partnership with King County, supporting development of IWRMS. Significant support for FVCOM development came from the U.S. Department of Energy and Pacific Northwest National Lab, and significant support for DHSVM came from the University of Washington PRISM program. And of course we are very grateful for the financial support from EPA's Puget Sound Science and Technical Studies Assistance Program, and to Chris Castner and his team at EPA Region $\mathrm{X}$ for their assistance and sage advice. 



\section{Acronyms and Abbreviations}

$3 \mathrm{D}$

CSO

DEM

DHSVM

EPA

ERDC

FRAMES

FVCOM

IPCC

IWRMS

LAI

LULC

$\mathrm{m}$

PNNL

PRISM

SSF

USGS

UW three-dimensional

Combined Sewer Overflow

digital elevation model

distributed hydrology-soil-vegetation model

U.S. Environmental Protection Agency

Engineer Research and Development Center

Framework for Risk Analysis in Multimedia Environmental Systems

Finite Volume Coastal Ocean Model

International Panel on Climate Change

Integrated Water Resource Modeling System

leaf area index

Land-Use/Land-Cover

meter(s)

Pacific Northwest National Laboratory

Puget Sound Regional Synthesis Model

Snohomish Sustainable Futures

U.S. Geological Survey

University of Washington 



\section{Contents}

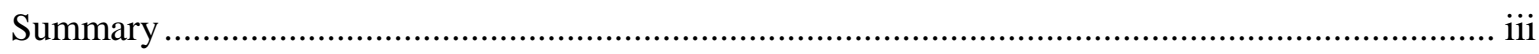

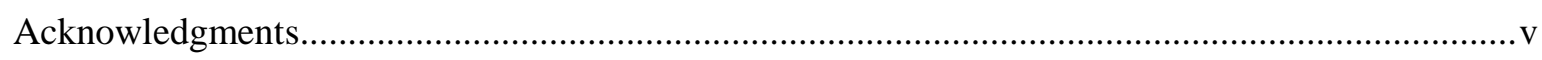

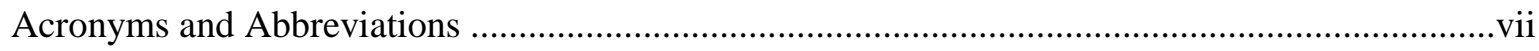

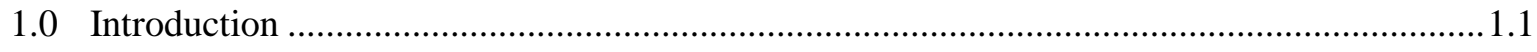

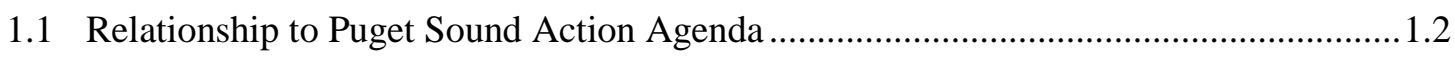

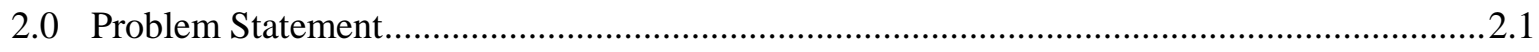

3.0 Using Water as Currency in the Snohomish Basin............................................................ 3.1

4.0 Management Questions Driving Research .................................................................... 4.1

4.1 Importance of Working with Water Resource Managers .............................................. 4.1

4.2 Origins of Snow Caps to White Caps .......................................................................... 4.1

4.3 Specific Input from Water Resource Managers ............................................................ 4.2

4.3.1 Sustainable Snohomish Futures Committee .................................................... 4.2

4.3.2 Input from Project Partners ........................................................................ 4.2

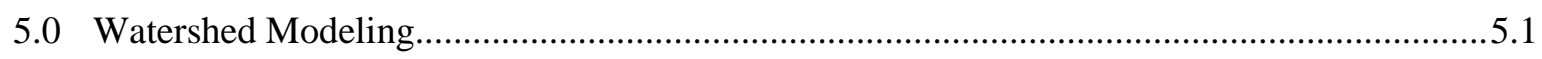

5.1 Distributed Hydrology-Soil-Vegetation Model .......................................................... 5.1

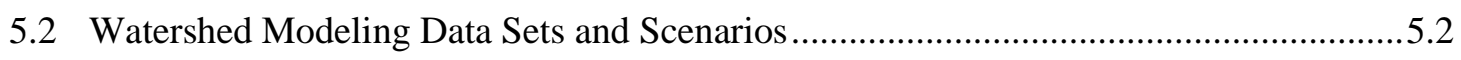

5.3 Changes in the Snohomish Basin under Future Modeling Conditions............................5.3

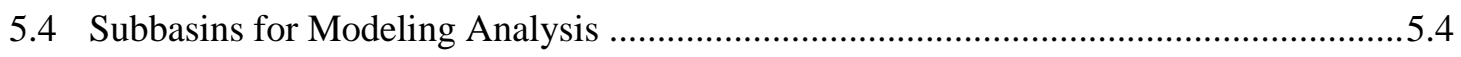

5.4.1 West Wood Creek ....................................................................................5.4

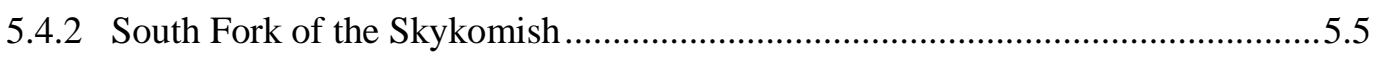

5.4.3 North Fork of the Snoqualmie Basin:..............................................................5.5

5.5 Significance of Climate Change and Land-Use Change in the Snohomish Basin ..........5.5

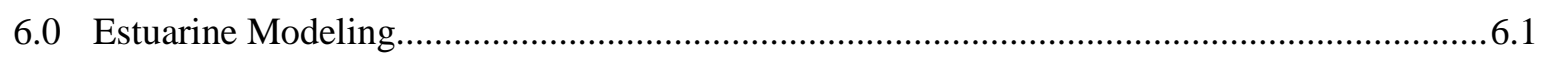

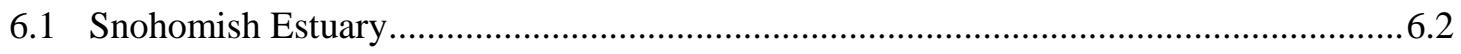

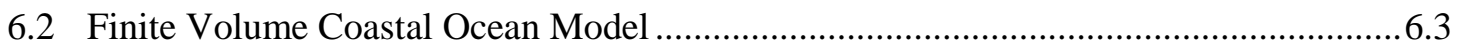

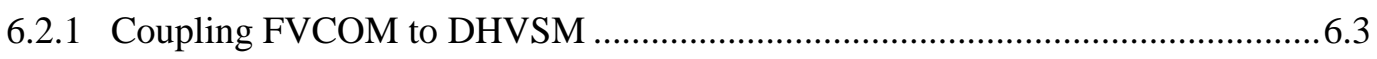

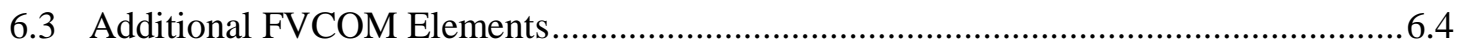

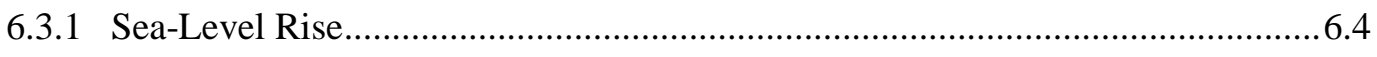

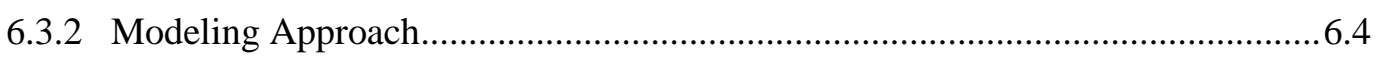

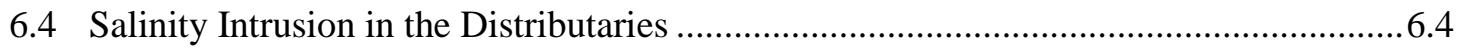

6.5 Inundation and Salinity in the Intertidal Zone and Floodplain....................................... 6.5

6.6 Estuarine Response to Sea-Level Rise Scenarios........................................................6.6

6.7 Simulation of Fecal Coliform Fate and Transport......................................................6.6

7.0 Integrated Water Resource Management System ............................................................ 7.1

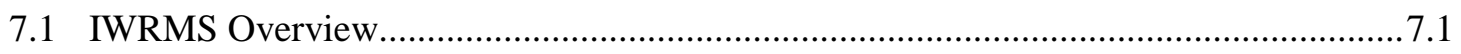

7.2 Benefits of IWRMS for this Project ….................................................................. 7.1 
7.3 Use of IWRMS to Support Snow Caps to White Caps...................................................... 7.2

7.4 Expansion of the Snow Caps to White Caps Concept Beyond the Snohomish Basin.....7.2

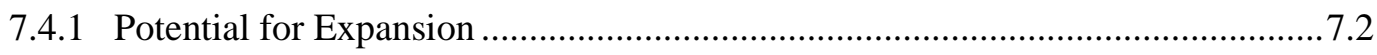

7.4.2 Inclusion of Additional Parameters .................................................................... 7.3

7.4.3 Use of Different Models ................................................................................. 7.3

7.4.4 Expanding the Geographic Extent.................................................................. 7.3

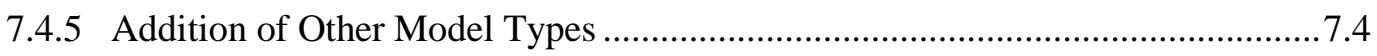

7.4.6 Alternate Modeling Scenarios ...................................................................... 7.4

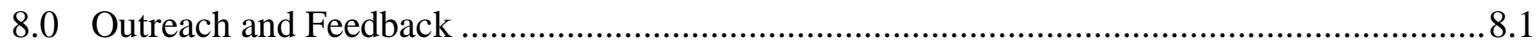

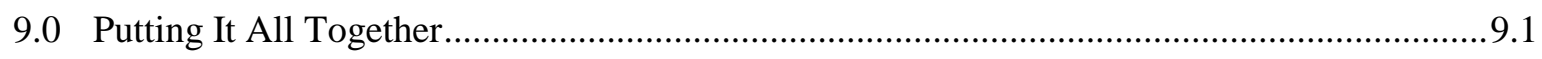

9.1 Application of LULC and Climate Scenarios .......................................................... 9.1

9.2 Questions Addressed by Snow Caps to White Caps......................................................9.2

9.2.1 Pressure Caused by Changes in Climate and LULC on Salmon Viability...........9.2

9.2.2 Extent of Flooding that Will Occur in the Lower Reaches of the Watershed due to Climate Change and Population Growth.......................................................9.4

9.2.3 Effects of Specific Forest Management Practices in the Upper Watershed on the Hydrology of the Basin ..................................................................................9.5

9.2.4 Fate and Effects of Biological Contamination in Marine Waters ........................9.5

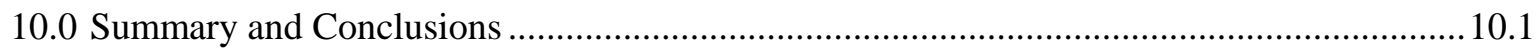

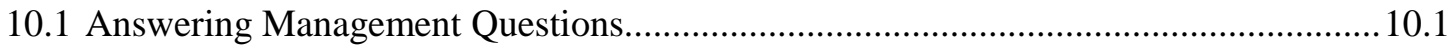

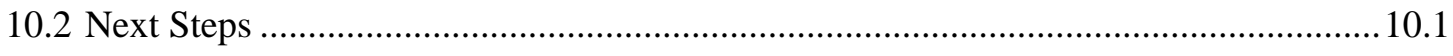

10.2.1 Expansion within Snohomish Basin............................................................. 10.1

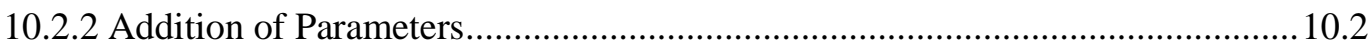

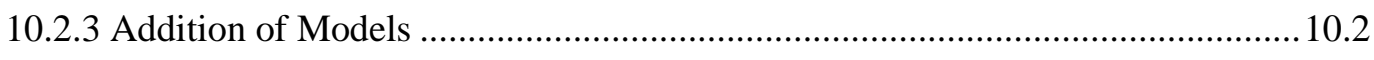

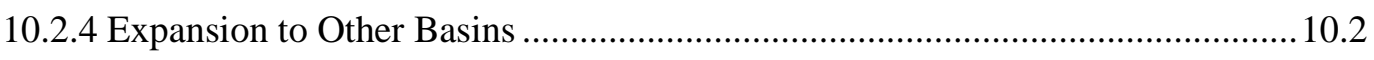

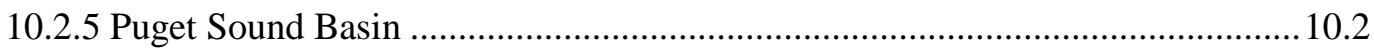

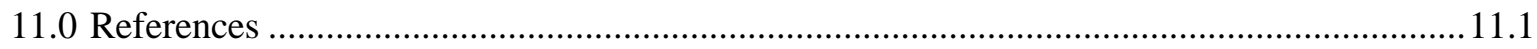

Appendix I. Watershed Hydrology under Climate Change and Land Use Land Cover Scenarios

Appendix II. Estuarine Hydrodynamic Responses to River Flow under Climate Change and Land Use Land Cover Scenarios

Appendix III. Integration of Models for Snohomish Basin: IWRMS 


\section{Figures}

Figure 1-1. The Snohomish basin in north-central Puget Sound, identified as the drainage for the Snohomish River. Just over half the area of the basin is contained within Snohomish County; the balance is in King County. The upper part of the watershed is mountainous and borders on Kittitas County. The lower part of the basin drains into the Snohomish River estuary through a set of sloughs, reaching Possession Sound in Puget Sound at Everett........1.2

Figure 5-1. The Snohomish basin watershed, indicating the location of USGS stream gauges used to drive flow in the DHSVM model. The stream gauge furthest downstream is located in the City of Monroe; flow at this site represents the culmination of changes within the entire watershed.

Figure 5-2. Elevation maps of the Snohomish basin upstream of Monroe (station \#1), with the annual hydrograph shown for each basin. Basin USGS gauges are located for reference. Red dots represent the three subbasins chosen for detailed analysis: (2) West Woods Creek; (3) South Fork Skykomish; (4) North Fork Snoqualmie. Monroe (1) is shown as the further downstream extent of watershed modeling and the start of floodplain and estuarine studies. 5.4

Figure 6-1. Snohomish River estuary in Puget Sound, Washington.

Figure 6-2. Distributary sloughs in the lower Snohomish River estuary.

Figure 6-3. FVCOM unstructured grid for the lower Snohomish River estuary. Water depth is shown for the river, sloughs, and nearshore estuarine area out to Possession Sound.

Figure 6-4 Comparison of salinity intrusion points in the distributaries of Snohomish River estuary. The negative values (distances) denote that the (Note: negative distance means the salinity intrusion point is downstream of the river mouth).

Figure 6-5. Comparisons of inundated areas at low tide for low river flows on left $\left(765 \mathrm{~m}^{3} / \mathrm{s}\right)$ and higher flows on right $\left(810 \mathrm{~m}^{3} / \mathrm{s}\right)$. Both simulations are shown at low tide.

Figure 6-6. Model results showing surface concentrations of fecal coliforms in Port Gardner of the Snohomish River estuary at ebb tide (left) and flood tide (right).

Figure 7-1. Schematic of IWRMS process of passing data from DHSVM to FVCOM, and the potential to pass data to and from other models.....

Figure 8-1. This figure represents an example of how the hydrographic curve will change from historical to future conditions, generated using Tableau. In this panel, the hydrograph is shown for Monroe under conditions of maximum flow (top), minimum flow (middle) and mean flow (bottom), over the water year. The colored lines represent the different land use and climate scenarios. The timing, flows, and location can be altered by the user to view how they will affect the timing and peak of the hydrograph.

Figure 8-2. An example from Tableau that shows the extent of the salinity intrusion point up the Snohomish River and distributaries and the inundated area of the floodplain, under different riverflow conditions, created due to changes in climate and LULC. The user can vary the river flow to investigate the manner in which the intrusion points and inundated areas will differ

Figure 9-1. Schematic of planning and model integration for Snow Caps to White Caps. 


\section{Tables}

Table 5.1. Summary of dominant drivers of change on specific flow characteristics by subbasin type. The change in flow is indicated where available; positive numbers indicate increases in flow, negative numbers are decreases in flow.

Table 5.2. Effects of forest management practices on specific flow characteristics, by subbasin type.

Table 9.1. Scenarios chosen for integration into modeling framework, aimed at examining questions of interest to water resource managers..... 


\subsection{Introduction}

The complex bathymetry and topography of the Puget Sound basin, strong ocean forcing, and complicated atmospheric terrain create a rich and varied ecosystem that supports a wide variety of organisms that call the marine waters, estuaries, and watersheds home. The region also provides a climate, living space, and rich amenities that have encouraged an ever-increasing settlement of humans, encouraging shoreline development, resource exploitation, creation of impervious surfaces, and changes in natural landscapes. With the addition of a global change in climate and specific atmospheric and ocean changes that are magnified in the north Pacific, the Puget Sound region is under stress that threatens to degrade and destroy many of the features that make it a desirable home for humans and other organisms. Research that will support effective management decisions is needed on many aspects of the interaction of natural and anthropogenic activities and populations in Puget Sound, including an understanding of the balance of freshwater and saltwater, as it affects habitats, ecosystem services, and future integrity of the basin.

The purpose of this project Integrated Modeling and Decision-Support System for Water Management in the Puget Sound Basin, familiarly known as Snow Caps to White Caps, is to provide data products and insight for water resource managers to support their predictions and management actions to address future changes in water resources (fresh and marine) in the Puget Sound basin. This project has been made possible through the generous support from the Environmental Protection Agency (EPA) Region X's Puget Sound Science and Technical Studies Assistance Program.

This report details the efforts of a team of scientists and engineers from Pacific Northwest National Laboratory (PNNL) and the University of Washington (UW) to examine the movement of water in the Snohomish basin (Figure 1-1), within the watershed and the estuary, under present and future conditions, using a set of linked numerical models.

The future conditions we have used in the modeling system represent reasonable estimates of conditions that may affect the water balance due to climate change and increasing human development in the basin. The specific scenarios and outputs were designed in close coordination with local water resource managers in Snohomish and King counties and the City of Everett. The results of the study are being presented to interested parties at the state and local level, and extrapolation of the potential for applying the Snow Caps to White Caps methods beyond the Snohomish to other Puget Sound basins is under way.

This report summarizes the work that has been carried out by the PNNL and UW team, describing the modeling efforts and linkages between watershed and estuarine models that create an integrated system to support water resource decisions. Details of the modeling methods and outcomes can be found in the technical appendices that accompany this report. The appendices also provide a description of the integrating system that allows us to look at more than the sum of the parts of the individual models. 


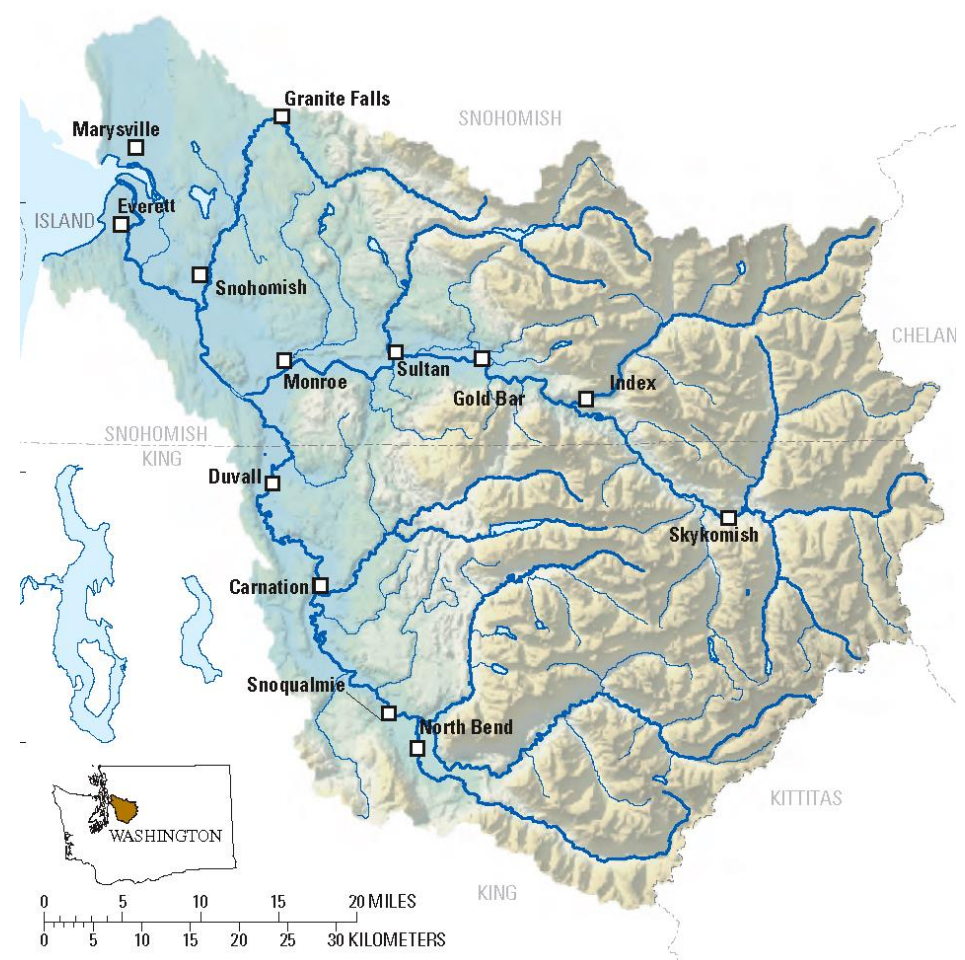

Figure 1-1. The Snohomish basin in north-central Puget Sound, identified as the drainage for the Snohomish River. Just over half the area of the basin is contained within Snohomish County; the balance is in King County. The upper part of the watershed is mountainous and borders on Kittitas County. The lower part of the basin drains into the Snohomish River estuary through a set of sloughs, reaching Possession Sound in Puget Sound at Everett.

\subsection{Relationship to Puget Sound Action Agenda}

This project will assist state and federal agencies, local governments, tribes, and other entities to work together effectively on priority actions (Priority D in PSP 2008), filling a critical program implementation need by contributing to the region's understanding of anticipated climate change effects (Priority D.2 in PSP 2008). Snow Caps to White Caps focuses on the magnitude and timing of streamflow in major rivers as an indicator of water quantity, and will support the PSP's Performance Management System for developing threat reduction objectives for stormwater loading and runoff as well as growth, restoration of rivers, floodplains and marine shorelines, water use, and water pollution from treatment plants and septic systems. This project will complement the development and use of watershed mapping tools to determine where growth, protection, and restoration should occur.

Snow Caps to White Caps supports protection and restoration of Puget Sound ecosystems and water quality; contributing to achievement of the 2006-1011 EPA Region 10 Strategy and several near-term priorities of the Puget Sound Partnership Action Agenda including: 
- Providing technical assistance for local land use management decisions including updating shoreline management plans, setting instream flow rules, updating critical areas ordinances, and watershed plans (Action numbers A.2 (5), A.2(8), A.3(1), A.3(4)).

- Developing comprehensive basin flow protection and enhancement programs called for in the recovery plans for Puget Sound Chinook and Hood Canal/Strait of Juan de Fuca summer chum (A.3(3)).

- Supporting the resolution of conflicts between aquaculture and upland uses with detailed and integrated watershed model and scenarios (A.4(5))

- Contributing technical expertise to the restoration of floodplain and river processes to recreate ecosystem function (B.1(3)).

- Providing technical assistance to cities and counties to implement NPDES permits (C.2(2)).

- Providing technical assistance to support implementation of priority strategies and actions to address low dissolved oxygen in South Sound, Whidbey Basin, and other areas (C.1(9)). 



\subsection{Problem Statement}

Increasing human populations and global climate change are challenges common to coastal areas worldwide. Degradation of Puget Sound has occurred over a period of 150 years; efforts are under way to halt the damage and restore function to the waterbody and surrounding watersheds. However these restoration efforts are complicated by two major forces (development and climate change); effects from both forces appear inevitable and both present major challenges for predicting their timing and extent. While climate change and increased human development will have direct effects on marine and fresh water organisms and habitats, strong impacts will be felt on the fresh and marine waters that support the overall function and health of Puget Sound. The balance and abundance of fresh and marine waters support Pacific salmon and other valued species, and have an effect on the interaction of humans with the land and sea through changes in flooding, use of the watershed for recreation and forestry, management of stormwater, and availability of salmon and other marine resources for harvest. Understanding the flow of water in the streams, rivers, and estuaries is essential to managing water resources under these changing conditions, particularly in basins where development pressures are highest. 



\subsection{Using Water as Currency in the Snohomish Basin}

Management of stormwater, flooding, and temperature stress on salmon are management priorities within the watersheds and estuaries of Puget Sound. Stormwater management in the Puget Sound basin ranks as one of the most serious and difficult challenges to the restoration of the Sound (PSP 2010). This challenge will become greater as increased development pressure in Puget Sound watersheds results in increased impervious surface for runoff, more population pressure brings increased toxic components into surface waters, and climate change radically changes our precipitation patterns and stream-flow configurations. Linkages between climate-induced changes in freshwater flow and resources in the Snohomish basin were projected by UW's Climate Impacts Group, which predicted strong negative impacts on Chinook salmon populations (Palmer et al. 2010). These management challenges depend on accurate estimates of the freshwater flow and water temperature delivered from snowpack and precipitation. With accurate flow estimates and timing, it will be possible to do the following:

- Predict flooding recurrence and flood levels.

- Estimate contaminant loads in stormwater.

- Determine the inundation of critical salmon habitat.

- Evaluate the effects of land-use changes on habitats and ecosystem services.

- Predict challenges to downmigrating juvenile salmon in the estuaries.

- Understand the distribution of chemical and biological contaminants in marine waters.

- Measure water-quality trends in the Salish Sea.

Using the Snohomish basin as our laboratory, our team has examined the flow of water from the top of the basin ("snow caps") through the watershed, to the estuary and Puget Sound ("white caps"), using established numerical models to simulate the timing and quantity of flow and, in the estuary, the temperature and salinity of the water. The models we have used were developed specifically to address water movement in a watershed (the distributed hydrology-soil-vegetation model [DHSVM]) or movement of ocean water (the Finite Volume Coastal Ocean Model [FVCOM]). Each model was adapted to the Snohomish basin, and each was used to simulate scenarios for the effect of changes in land use (using land cover as a proxy), and/or future climate change based on selected International Panel on Climate Change (IPCC) scenarios. To create a linkage and system of models from the top to the bottom of the basin, we adapted the framework of the Integrated Water Resource Modeling System (IWRMS), which was created to support King County Natural Resources and Parks' freshwater modeling efforts. The linkage and integration of the models into a system represents the unique aspects of the Snow Caps to White Caps concept and illustrates the promise of further integration of additional models and model types into the system, as well as the portability of the system to other Puget Sound subbasins, and ultimately to the entire basin. This project must be considered as a proof of concept, rather than a fully built out system. Our team's intent was to show the potential, work out the linkages, and adapt existing models to address water resource questions of interest to local managers. 



\subsection{Management Questions Driving Research}

The impetus for this study was the need to assess the capability of modeling systems to meet the needs of water resource managers by enhancing the way in which individual models can communicate with one another to create value-added outcomes, and to ensure that the results are responsive to the needs of, and made accessible to, the resource managers.

\subsection{Importance of Working with Water Resource Managers}

Many members of the research team from PNNL and UW that undertook this study have close ties with water resource, salmon restoration, and marine resource managers in the Puget Sound basin and have engaged in regional and local discussions of management needs for many years. However, the team recognized the need to engage directly with the resource management community from the start and throughout the project to ensure that the modeling tools created and the future scenarios tested were aimed at realistic and important questions that the managers face in the course of their work. The PNNL and UW team met in large and small groups with resource managers, with a particular emphasis during the first and last years of the project to determine the most important questions to pursue, and to check back with the managers after initial model runs and outcomes were developed to ensure that the work was directed in the most useful manner. The final aspect of the project entailed an outreach campaign that will continue past the formal end of the EPA-funded project to ensure that the results are shared with state and local resource managers who might benefit from the outcomes.

\subsection{Origins of Snow Caps to White Caps}

This study could not have happened without extensive cooperation from a range of water resource managers and other interested parties. The origins of Snow Caps to White Caps goes back well before the inception of the project. Beginning in 2006, a group of Snohomish and King county resource managers, tribal managers, researchers, and elected officials began to discuss potential futures for the Snohomish basin, and to envision the technical tools that might assist with those futures. Two lines of strong interest arose: the use of predictive modeling tools to aid water and salmon resource managers in decisionmaking; and alternative effective methods for compensatory mitigation banking and trading. Based on the expressed level of interest, in 2008 under the leadership of (then) Snohomish County Council members David Somers and John Koster, the Snohomish Sustainable Futures (SSF) Steering Committee was formed. The SSF Steering Committee included Snohomish and King county elected officials and resource managers; municipal organizations and agencies including the City of Everett; tribal representatives from the Tulalip and Stillaguamish tribes; Washington State agencies including the Governor's Office; Snohomish County business interests; and non-governmental economic development and environmental organizations. PNNL assisted in staffing the committee. The committee met several times throughout 2008 and developed a report that recommended that both lines of interest (technical modeling tools and alternative mitigation strategies) be pursued. The alternative mitigation strategies followed a pathway through the state. With EPA support, Snow Caps to White Caps has taken a step in fulfilling the modeling tools pathway. 


\subsection{Specific Input from Water Resource Managers}

Input from resource managers that drove this project was grounded in the work of SSF Steering Committee, and continued with individual and specific groups of resource managers as this project began in 2009-2010.

\subsubsection{Sustainable Snohomish Futures Committee}

Due to PNNL staff involvement with the SSF Steering Committee from 2007 to 2008, the project team was able to engage in discussions around the needs identified by this broad-based group (SSF 2009).

The SSF Steering Committee came together to consider foundational components of performancebased approaches to resource management, as well as applications in areas where there are opportunities for significant improvement, such as mitigation and stormwater management. The committee members understood that current, first-generation environmental management strategies are, in many cases, at a point of diminishing returns - increasingly high-cost and low-benefit; and that conventional regulatory processes and approaches alone are insufficient to achieve a sustainable future. SSF committee members believed that:

Recent advances in our understanding of watershed and estuary function, hydrodynamic modeling, and water management, create an opportunity to bring this information and analysis together in an integrated manner. In addition to a foundation of good science and plans, Snohomish County has challenges associated with rapid growth, and the innovative, collaborative spirit and bi-partisan leadership to demonstrate new and better ways of managing our land, water, economic needs, and quality of life. In fact, the County was selected by the Legislature as one of two Alternative Mitigation Pilot projects in the State. Progress in these areas is being made around the Northwest, but Snohomish County appears to be poised to bring these pieces together in a uniquely beneficial manner.

Excerpted from Snohomish Sustainable Futures Report, 2009

The SSF Steering Committee agreed to identify and promote the use of sustainable tools and strategies that help achieve several objectives, including sustainable development, net benefit mitigation, integrated and efficient permitting, and strategies to sustain farms and working forests. The committee found that Snohomish County could benefit from the application of watershed information and new resource management tools and strategies to achieve a more sustainable future. A prerequisite for performance-based resource management is a foundation that includes integrated watershed and land information and plans; monitoring and analysis (including advanced modeling) to measure and verify performance; and regulatory latitude and guidance to demonstrate this new approach. Applications that should be built on this foundation, the committee felt, included a watershed approach to mitigation, and performance-based stormwater management.

\subsubsection{Input from Project Partners}

As the project team developed the concept for this project, project partners (Snohomish County Surface Water Management; King County Natural Resources and Parks; City of Everett Public Works Department) shared their interests and needs, in the context of the challenges that each manager expects 
to face in 5 to 10 years while managing the natural resources under his/her jurisdiction. Meetings of the PNNL/UW project team with these project partners and others in the region continued periodically throughout the project. While many ideas and needs were discussed and considered, the project team determined that the most effective areas where the Snow Caps to White Caps concept could provide targeted assistance were related to the need to better understand the distribution of water resources throughout the basin, against the backdrop of climate change and Land-Use/Land-Cover (LULC) changes, in particular by examining the following:

- effect of changes in precipitation patterns and stream flows in upper watershed on the estuary

- pressure caused by changes in climate and LULC on salmon viability in the basin

- extent of flooding that will occur in the lower reaches of the watershed due to climate change and population growth

- effects of specific forest management practices in the upper watershed on the hydrology of the basin

- fate and effects of fecal coliform bacteria from City of Everett stormwater on shellfish in Port Gardner Bay.

The integrating theme of these management needs was determined to be the need for an accurate spatial and temporal understanding of freshwater flows throughout the watershed, and the translation of those flows into the estuary. This integration led to the series of modeling studies and integration efforts carried out during this project. 



\subsection{Watershed Modeling}

Understanding the movement of water through the Snohomish basin requires that we examine the highest reaches of the mountain peaks that catch snow seasonally, the many tributaries and wetlands that feed the main stem of the river, the spread of the river across the floodplain, and the channeling down to the deltaic river mouth as it enters Port Gardner Bay at Everett. The movement of water from the mountain tops to the floodplain was simulated in our study using the DHSVM watershed model, which was created during the 1990s specifically for use in Pacific Northwest watersheds. Since its inception, the DHSVM has undergone numerous improvements and expansions and is commonly recognized in the region as an excellent base model for the simulation and prediction of water flow across Pacific Northwest landscapes.

The objectives of the watershed study were as follows:

- Develop an approach to couple the watershed hydrology model to the estuarine model that reconciles the temporal, spatial, and dimensional structures of the models.

- Provide information at seasonal and shorter time scales that describes the effects of climate and landuse changes on freshwater inflow into the estuary model.

- Evaluate the effects of recent land-use changes, in particular forestry practices, in the upstream part of a snow-rain transition basin for application to stream restoration under the effects of climate change.

The Snohomish basin is a snow-rain transition basin located on the western slopes of the Cascade Mountains range in Washington State, discharging into Puget Sound, a deep fjord-type estuary. The Puget Sound basin has been the object of extended studies of the impact of land use and climate change on freshwater (Cuo et al. 2009; Cuo et al. 2011; Elsner et al. 2010). We have leveraged these analyses and modeling approaches, altering initial conditions and using different LULC data, to address the research objectives.

This section of the report provides a brief summary of the watershed modeling effort; the full results are available in Appendix 1.

\subsection{Distributed Hydrology-Soil-Vegetation Model}

The DHSVM was originally designed for mountainous forested watersheds and is primarily a saturation excess model (Wigmosta et al. 1994, 2002). Recently however, Cuo et al. (2008) adapted the model to represent aspects of runoff generation in urban basins, including impervious surfaces, and runoff detention and release in artificial conveyance systems, such as pipes and ponds.

DHSVM represents the physical processes that control runoff, including the land surface energy balance, unsaturated soil moisture movement, saturation overland flow, snow melt and accumulation, and water table recharge and discharge. Using a digital elevation model (DEM) as a base map, DHSVM explicitly accounts for soil and vegetation types, and stream channel network and morphology. Landclass attributes used by DHSVM include soil surface properties such as impervious surface area and infiltration capacity; vegetation morphology parameters such as vegetation height, canopy coverage fraction, and trunk size; and vegetation phenology characteristics such as minimum stomatal resistance, 
leaf area index (LAI), and albedo. These parameters are used for calculating surface-water infiltration, the wind profile through the vegetated canopy, radiation balance through the canopy, and water vapor transport.

DHSVM has been widely used in the Pacific Northwest, with an emphasis on the effects of forest harvest on runoff (Storck et al. 1998; Bowling et al. 2000; Schnorbus et al. 2004). DHSVM was implemented throughout the Puget Sound basin for the effects of changes in land cover (1883 vs. 2002) and climate change from 1915 to 2006 (Cuo et al. 2009). These same model parameters were used to study the effects of future climate and land-cover change on the hydrology of the Puget Sound basins in Cuo et al. (2011). DHSVM has also been used to assess the effect of climate change on water resources for the Sultan Basin (Vano et al. 2010).

DHSVM uses a fine-scale grid of $150 \mathrm{~m}$ by $150 \mathrm{~m}$, and runs with a 3-hourly time step. The model requires hourly meteorological input that includes air temperature, precipitation, relative humidity, incoming solar and longwave radiation, and wind speed.

\subsection{Watershed Modeling Data Sets and Scenarios}

The water flow data driving the DHSVM for this study were derived from U.S. Geological Survey (USGS) stream gauges, as shown in Figure 5-1. The furthest downstream gauge at Monroe represents the location where the flows from the watershed model are handed off to the estuarine model.

The LULC data used in the model were derived from USGS Landsat (Thematic Mapper and Enhanced Thematic Mapper) images of central Puget Sound. Landsat data were registered, intercalibrated, and corrected for atmosphere and topography to ensure the accuracy of the land-cover change assessment. The LULC data were obtained from the Urban Ecology Research Laboratory (Puget Sound Regional Synthesis Model (PRISM), University of Washington, http://urbaneco.washington.edu/wp/resources/data/).

The LULC layers used as the base or historical case were provided by Snohomish County, following surveys completed in 2002. Future LULC layers used in the modeling analyses included the future case projected to 2050, developed collaboratively by PNNL, UW, and Snohomish County. In addition, a new LULC layer was developed for 2007 to study the effects of forestry practices on stream flow (Central Puget Sound 2007 Land Cover Classification. Puget Sound Regional Synthesis Model (PRISM). University of Washington.) The 2007 LULC layer was further processed to create a synthetic data set that assumed that, for the period from 2002 to 2007, no trees were removed from the basin and the remaining trees were allowed to develop into a mature forest with a canopy height of $55 \mathrm{~m}$. The two 2007 LULC layers were designated as 2007 Business as Usual and 2007 Mature, respectively.

Climate change forces were derived from two IPCC climate scenarios, A1B and B1. Scenario A1B is characterized as representing a future world with very rapid economic growth, global population that peaks in mid-century and declines thereafter, and the rapid introduction of new and more efficient technologies. The energy sources under this scenario represent a balance between fossil fuels and nonfossil fuels. Scenario B1 describes a future world with the same global population that peaks in 


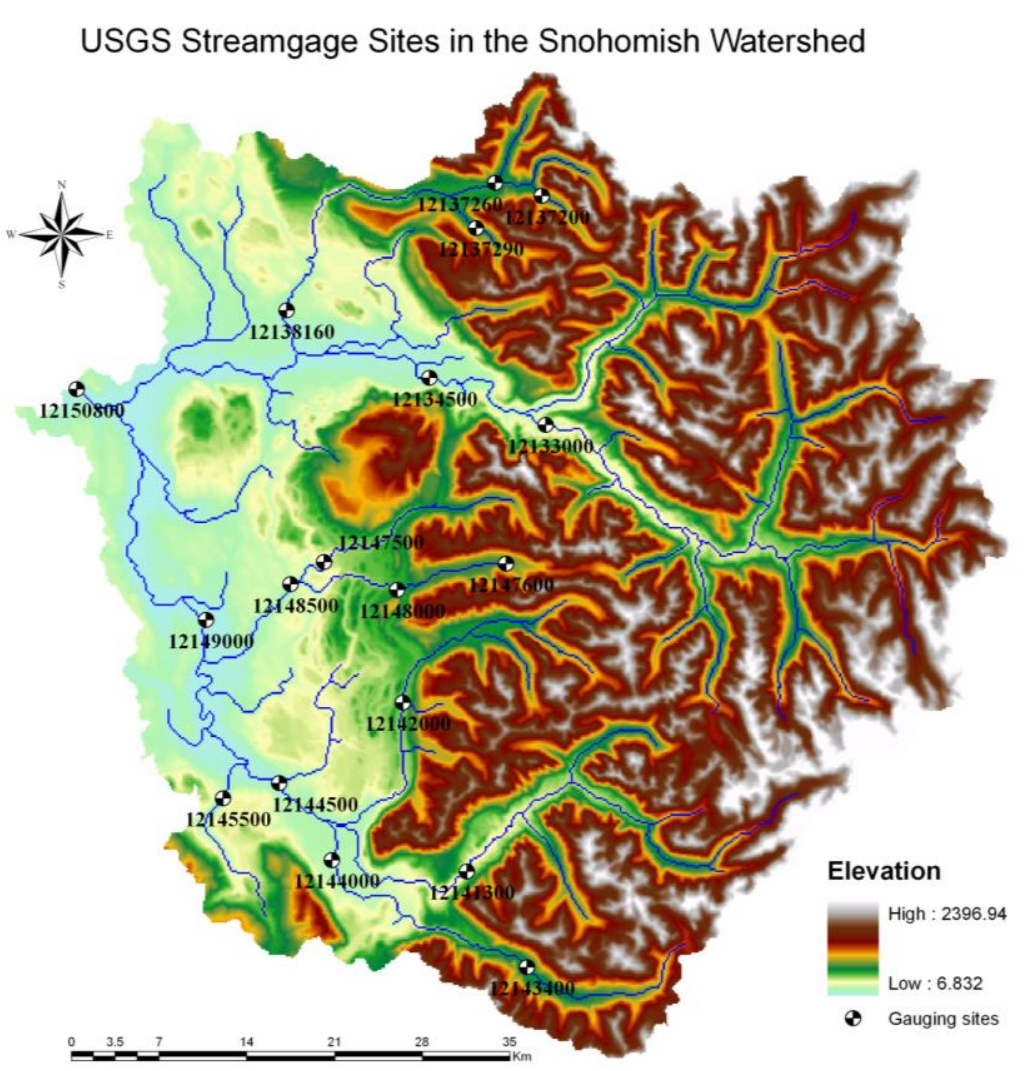

Figure 5-1. The Snohomish basin watershed, indicating the location of USGS stream gauges used to drive flow in the DHSVM model. The stream gauge furthest downstream is located in the City of Monroe; flow at this site represents the culmination of changes within the entire watershed.

mid-century but with rapid changes in economic structures toward a service and information economy, with reductions in material intensity, and the introduction of clean and resource-efficient technologies. Forces driving water flows in the Snohomish basin will be less subject to strong effects of climate change under scenario B1 than scenario A1B.

\subsection{Changes in the Snohomish Basin under Future Modeling Conditions}

Observing changes in flow due to climate and/or LULC changes at Monroe allows us to integrate all changes that occur upstream in the watershed. Overall, our model runs tell us that climate change will affect the hydrology of the basin more than changes in LULC. The overall annual flow in the river will not change significantly under future climate changes, but there will be changes in the timing of flow and thus future flooding and challenges to salmon habitat, outmigration, and survival. The greatest contributions to flow at Monroe are from snowmelt and rain-snow transition areas, which in turn are most highly affected by climate change. Climate change is projected to affect the basin with an increase in total rain rather than snow, particularly increasing the fall flow peak, and a decrease in the snowmelt peak with an earlier snowmelt in spring. 
Considering the effect of forest management practices on the upper reaches of the Snohomish basin, we can expect that allowing trees to reach maturity will decrease the overall flow in the river by about $10 \%$ as the forest canopy, decreased evapotranspiration, and maintenance of slopes and soils retain water higher up in the watershed. Flooding downstream will decrease if mature forests in the upper reaches are maintained.

\subsection{Subbasins for Modeling Analysis}

Three subbasins within the Snohomish basin were chosen to test the effects of LULC and climate changes on the hydrology; each presented a different place and condition in the watershed. The three basins are indicated in Figure 5-2 and described here. The city of Monroe is also noted and represents the location where the tributaries of the Snohomish River converge and flow as a single river through the floodplain. This location also represents the convergence of the watershed and estuarine modeling for this project.

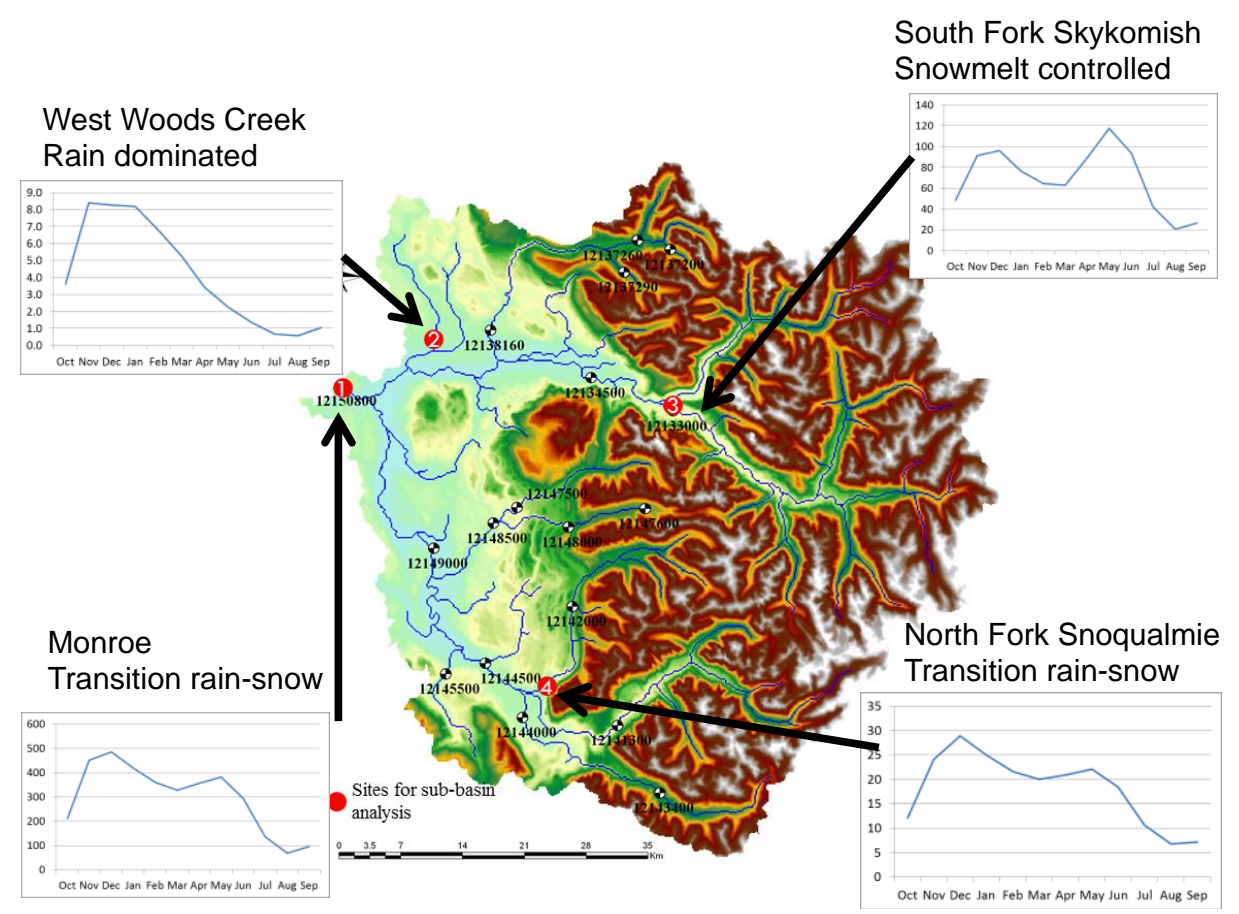

Figure 5-2. Elevation maps of the Snohomish basin upstream of Monroe (station \#1), with the annual hydrograph shown for each basin. Basin USGS gauges are located for reference. Red dots represent the three subbasins chosen for detailed analysis: (2) West Woods Creek; (3) South Fork Skykomish; (4) North Fork Snoqualmie. Monroe (1) is shown as the further downstream extent of watershed modeling and the start of floodplain and estuarine studies.

\subsubsection{West Wood Creek}

West Woods Creek is a rain-dominated basin located just upstream of Monroe with a single peak hydrograph overlapping the fall and winter seasons. The mean monthly flow climatology is more sensitive to changes in LULC than to climate change. With the 2007 Mature forest LULC, the annual 
amount of water flowing in the stream is significantly lower (-29\%); although the summer flow will not change, there will be a much lower fall and winter flow as rain is intercepted by the forest canopy and is lost by higher evapotranspiration due to heating. The effect of climate change on annual daily floods is equivalent for both LULC. It is important to note however that the water flow through this subbasin is very low, so there is a high degree of uncertainty associated with results of the modeling analyses.

\subsubsection{South Fork of the Skykomish}

The South Fork of the Skykomish River is a rain-snow transition basin that is largely controlled by snowmelt at present, with a higher snowmelt peak flow than fall flow. Climate change will be the predominant driver of change in this basin, causing a decrease in the snowmelt peak and an increase in the fall flow peak. Under future climate conditions, this subbasin will move closer to being a rain-snow transition basin more highly controlled by rain, with an earlier snowmelt. While LULC has less effect on the flow in this subbasin, the presence of a mature forest (i.e. the 2007 Mature LULC) will decrease the overall flow from the subbasin by about $65 \%$ but will not alter the seasonality of the hydrograph.

\subsubsection{North Fork of the Snoqualmie Basin:}

The North Fork is a rain-snow transition basin; river flows are expected to be affected significantly by both climate and LULC changes. Climate change is expected to change the seasonality of the flow, decreasing the snowmelt peak as more precipitation falls as rain, and increasing the fall peak, with snowmelt occurring earlier, although the overall total flow (water balance) in the subbasin is expected to stay about the same with climate change. If the 2007 Mature LULC is superimposed on the subbasin, the seasonality of the flow is not expected to change but the overall flow in the river will be decreased by $14 \%$. Extreme floods are projected to increase due to climate change, but will not be affected by forest management practices.

\subsection{Significance of Climate Change and Land-Use Change in the Snohomish Basin}

Focusing on the Snohomish basin in its entirety, our modeling results suggest that future climate changes will have more effect on the flow rates at the downstream portion of the watershed that feeds into the floodplain and the estuary than will changes in LULC. From a management perspective this is useful information but leaves water resource managers with the need to plan for and mitigate these changes. However, examining individual subbasins, it is clear that forces over which managers may have greater control, such as changes in LULC, are also highly important, as shown in West Wood Creek and the south fork of the Skykomish. In addition, changes in the hydrograph involve many more details than simply assessing changes in the annual water budget and the timing of peak runoff. If we look across the subbasin types modeled, we see that different flow characteristics can be controlled by climate change, LULC, both, or neither (Table 5.1). If we were to examine the results of managed forests (those where trees are cut on a rotating basis and the canopy does not rise above $43 \mathrm{~m}$ ), we would see that the effect on specific flow characteristics varies with hydrologic condition (Table 5.2). Based on these outcomes, it is critical that water resource managers determine which characteristics of flow are likely to create the greatest future threats to salmon habitats, slope and wetland stability, and downstream flooding. Details 
on all the flow characteristics, outcomes of modeling runs, and correlations and sensitivity analyses can be found in Appendix I.

Table 5.1. Summary of dominant drivers of change on specific flow characteristics by subbasin type. The change in flow is indicated where available; positive numbers indicate increases in flow, negative numbers are decreases in flow.

\begin{tabular}{|c|c|c|c|}
\hline $\begin{array}{c}\text { Subbasin } \\
\text { Characteristics } \\
\end{array}$ & Rain-Dominated & $\begin{array}{c}\text { Rain/Snow- } \\
\text { Dominated }\end{array}$ & $\begin{array}{l}\text { Snowmelt- } \\
\text { Dominated }\end{array}$ \\
\hline $\begin{array}{l}\text { Mean annual water } \\
\text { balance }\end{array}$ & $\begin{array}{l}\text { Forest Management } \\
(29 \%)\end{array}$ & $\begin{array}{l}\text { Forest Management } \\
(10 \%)\end{array}$ & $\begin{array}{l}\text { Forest Management } \\
(6 \%)\end{array}$ \\
\hline $\begin{array}{l}\text { Extreme annual } \\
\text { daily flood }\end{array}$ & $\begin{array}{l}\text { Forest Management } \\
+ \text { Climate Change }\end{array}$ & Climate Change & Climate Change \\
\hline 7-day low flow & NA & Climate Change & Climate Change \\
\hline $\begin{array}{l}\text { Daily flow } \\
\text { variability }\end{array}$ & $\begin{array}{l}\text { Forest Management } \\
(-17 \%)\end{array}$ & $\begin{array}{l}\text { Climate Change } \\
\text { (14 to } 20 \% \text { ) }\end{array}$ & $\begin{array}{l}\text { Climate Change } \\
8 \text { to } 14 \% \text { ) }\end{array}$ \\
\hline
\end{tabular}

Table 5.2. Effects of forest management practices on specific flow characteristics, by subbasin type.

\begin{tabular}{llll}
\hline \multicolumn{1}{c}{$\begin{array}{c}\text { Subbasin } \\
\text { Characteristics }\end{array}$} & Rain-Dominated & \multicolumn{1}{c}{$\begin{array}{c}\text { Rain/Snow- } \\
\text { Dominated }\end{array}$} & $\begin{array}{c}\text { Snowmelt- } \\
\text { Dominated }\end{array}$ \\
\hline $\begin{array}{l}\text { Mean annual water } \\
\text { balance }\end{array}$ & Increase & Increase & Increase \\
$\begin{array}{l}\text { Extreme annual } \\
\text { daily flood }\end{array}$ & Increase & No effect & No effect \\
7-day low flow & NA & Slight increase & None \\
\hline
\end{tabular}




\subsection{Estuarine Modeling}

Downstream of the watershed in the Snohomish basin lies the dendritic estuary and river mouth where the Snohomish River enters the Puget Sound at Everett. The Snohomish River forms at the confluence of the Skyhomish River and Snoqualmie River at river kilometer 40 near the city of Monroe, and connects to the main basin of Puget Sound through Possession Sound in the west and the Saratoga Passage and Port Susan Bay in the north (Figure 6-1). The Snohomish River is the second largest river in Puget Sound and accounts for about $30 \%$ of the freshwater discharge to Whidbey Basin. The long-term annual average river flow, measured at the USGS stream gauge at the city of Monroe, is approximately $270 \mathrm{~m}^{3} / \mathrm{s}$. The river flow of Snohomish River varies seasonally, with recorded minimum monthly flow of $32 \mathrm{~m}^{3} / \mathrm{s}$ and maximum monthly flow of $838 \mathrm{~m}^{3} / \mathrm{s}$, based on 50 years of records from 1963 to 2012 .

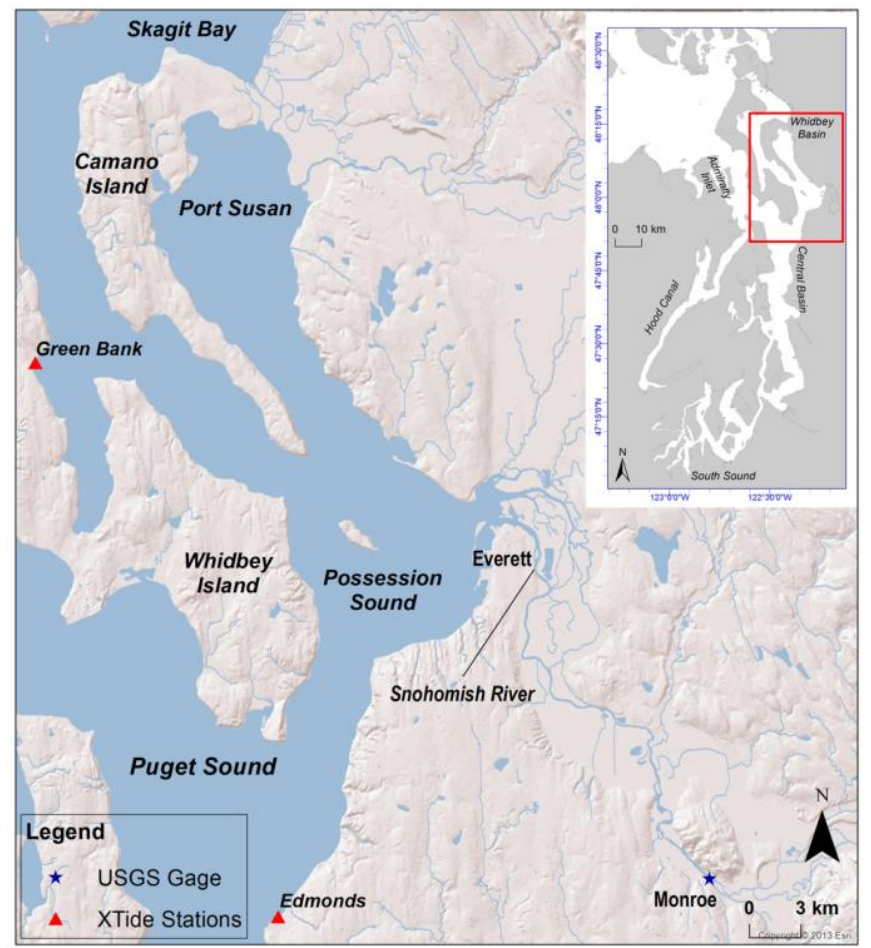

Figure 6-1. Snohomish River estuary in Puget Sound, Washington.

Determining the effects of climate change and LULC change on the estuary and floodplain requires an understanding of the dynamics of tidal circulation, mixing, and salinity intrusion in the estuary. These processes are complicated by the geometry of Puget Sound and its estuaries, and by multiple forcing mechanisms including tides, winds, and river flows. To better understand nearshore hydrodynamics and provide useful information to assist water management in the Snohomish River, we applied a highresolution three-dimensional (3D) coastal model (FVCOM) to the Snohomish River estuary and floodplain that was developed based on a previous study by Yang et al. (2010). In addition to evaluating the effects of LULC and climate changes in the watershed on the downstream estuary and floodplain, our study also looked at the effects of sea-level rise on the estuarine hydrodynamics, based on sea-level rise projections in the Puget Sound region by the end of the century (NRC 2012). An additional modeling study demonstrated the fate and transport of fecal coliform bacteria as it might be discharged in stormwater from combined sewer outfalls from the City of Everett into Port Gardner Bay. 
The objectives of the estuarine study were as follows:

- Determine the extent and salinity of floodwaters in the lower estuary under climate change and LULC scenarios, forced from the watershed and the ocean.

- Determine the extent of salinity intrusion into the sloughs and main stem of the Snohomish River due to changes in flow from the river and sea-level rise.

- Determine the fate and transport of fecal coliforms discharged from the City of Everett into Port Gardner Bay.

\subsection{Snohomish Estuary}

The Snohomish River discharges into Possession Sound through several large distributaries, including Ebey Slough along the north side of Snohomish delta; through Steamboat Slough and Union Slough through the middle of the delta; and the main stem of the Snohomish River along the south side of the delta and Everett Peninsula (Figure 6-2). These distributary sloughs provide important wetland and salmon habitat for juvenile salmon before they migrate from the freshwater to the saltwater environment (Greene and Beechie 2004; Scheuerell et al. 2006).

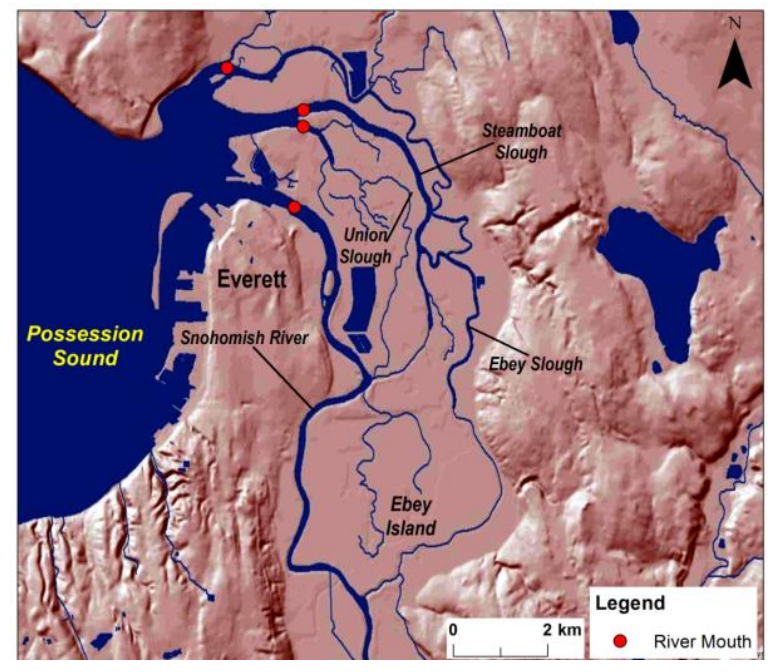

Figure 6-2. Distributary sloughs in the lower Snohomish River estuary.

Circulation in the Snohomish River estuary is dominated by tides from Puget Sound and strongly influenced by river inflow and the complex geometry in the lower estuary. There is a large, shallow, river delta present at the mouth of the Snohomish River as a result of upstream sediment loads and deposition. Many intertidal tide flats and estuarine wetlands exist in the lower Snohomish River estuary. Densityinduced currents are important in the Snohomish River estuary because of salinity stratification and intrusion. Well-defined two-layer estuarine circulation and variation of salinity gradients, in both the vertical and longitudinal directions, are distinct features in the Snohomish River estuary (Yang et al. 2010).

This section of the report provides a brief summary of the estuarine and floodplain modeling effort; the full results are available in Appendix II. 


\subsection{Finite Volume Coastal Ocean Model}

Our estuarine modeling study used the FVCOM, developed at the University of Massachusetts (Chen et al. 2003). FVCOM is a 3D, unstructured-grid, finite volume coastal ocean model that has a robust capability of simulating wetting and drying processes in the intertidal zone. FVCOM solves the 3D momentum, continuity, temperature, salinity, and density equations in an integral form for watersurface elevation and flow fields. Companion modules for sediment transport, water-quality kinetics, and biological models are integrated into FVCOM. The model computes water depths, velocities, salinities, and water-surface elevations based on the geometry and bathymetry of the system, the specified lateral and vertical boundary conditions, and model input parameters. FVCOM has been extensively applied to simulate hydrodynamics and transport processes in many coastal regions and estuaries around the world, including several estuaries and bays in Puget Sound (Zhao et al. 2006; Rego and Li 2010; Dukhovskoy and Morey 2011; Yang and Khangaonkar 2009; Yang et al. 2010, 2012; Xing et al. 2012; Chen et al. 2012; Yang and Wang 2013).

FVCOM was adapted for use in the Snohomish estuary with an unstructured grid that covered the estuary and the floodplain, based on a study by Yang et al. (2010), as seen in Figure 6-3. Additional details of the model set up can be found in Appendix II.

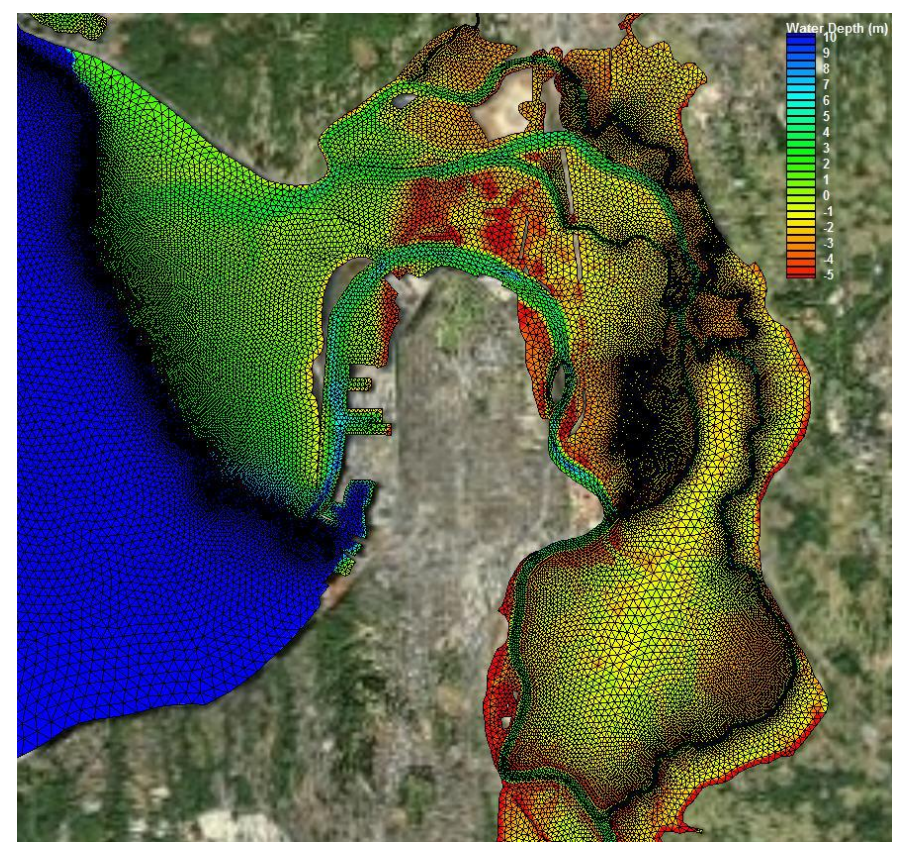

Figure 6-3. FVCOM unstructured grid for the lower Snohomish River estuary. Water depth is shown for the river, sloughs, and nearshore estuarine area out to Possession Sound.

\subsubsection{Coupling FVCOM to DHVSM}

FVCOM receives the output from DHSVM in the form of flow characteristics at the Monroe station; the output includes historic and future conditions for LULC and climate change scenarios. Time scales between the responses of river flow differ between the two systems; the hydrodynamic response time to the river flow in the Snohomish River estuary is shorter, typically on the order of days or less. For this reason it is not necessary to run the estuarine model for long periods covering seasonal variations, but 
rather to use constant river flows (monthly mean flow conditions) to study the estuarine hydrodynamic response to river flows under climate change and LULC scenarios. LULC scenarios from DHSVM included the historical (2002) and projected future (2050) scenarios; the 2007 LULC was not used as input to FVCOM because these layers (2007 Business as Usual and 2007 Mature) were developed specifically to examine the effects of forestry practices high up in the watershed, which are not seen to affect the lower estuary. Additional details on calculating the appropriate statistics for input to FVCOM from DHSVM can be found in Appendix II.

\subsection{Additional FVCOM Elements}

The FVCOM was also used to simulate the effects sea-level rise and the historical hydrodynamics and salinity patterns of the Snohomish estuary.

\subsubsection{Sea-Level Rise}

One of the most distinctive features of climate change in coastal areas is the rise of sea level. Effects of sea-level rise on the estuarine hydrodynamics in Snohomish River were investigated by superimposing the values of sea-level rise on top of the tidal elevation boundary conditions. To separate the effects of sea-level rise and changes in river flow due to future climate change and LULC, sea-level rise scenarios were simulated with river flow under historical monthly lowest, average, and highest flow conditions.

\subsubsection{Modeling Approach}

The historical hydrodynamics and salinity patterns of the Snohomish estuary were simulated using FVCOM over a 30-day cycle to ensure that conditions under neap and spring tides were represented. FVCOM was then modified, using physics to describe the basic processes, and the resulting analytical formulas added to model parameters of interest. FVCOM runs to examine the effects of LULC and climate changes focused on the response of the estuarine hydrodynamics to river flow by quantifying: 1) the salinity intrusion point (or furthest landward extent of saltwater flow) in each of the river distributaries, 2) the area of the intertidal zone and floodplain that is inundated, 3) the average water depth in each distributary and floodplain, and 4) the average salinity in the inundated areas. Responses of these parameters to LULC and climate-change scenarios were then interpreted from the model outputs.

\subsection{Salinity Intrusion in the Distributaries}

Salinity intrusion in a river distributary was defined as the presence of saltwater at $0.5 \mathrm{ppt}$ or more on the river bottom; the intrusion is measured as the distance from the location of the elevated salinity to the mouth of the river. The location of the river mouth for each distributary was based on the definition from the Washington State Department of Ecology (Figure 6-2). Salinity intrusion points in an estuary depend highly on the dynamic balance of tide and river flow and can vary significantly over spatial and temporal scales. The location of salinity intrusion moves upstream and downstream in an estuary during a tidal cycle, and varies considerably over a spring-neap tidal cycle.

The distance of salinity intrusion is a nonlinear function of river flow; a more pronounced increase in salinity intrusion occurs upriver during low river flows. Conversely, during high river flows, salinity 
intrusions are much smaller. In the Snohomish River, under high flow conditions, saline water does not move up into Union Slough and Steamboat Slough. Under low flow conditions (less than $150 \mathrm{~m}^{3} / \mathrm{s}$ for Union Slough and less than $100 \mathrm{~m}^{3} / \mathrm{s}$ for Steamboat Slough), salinity intrusion points in Union and Steamboat sloughs were pushed upstream by tides and joined the salinity intrusion point in the main riverstem (Figure 6.4).

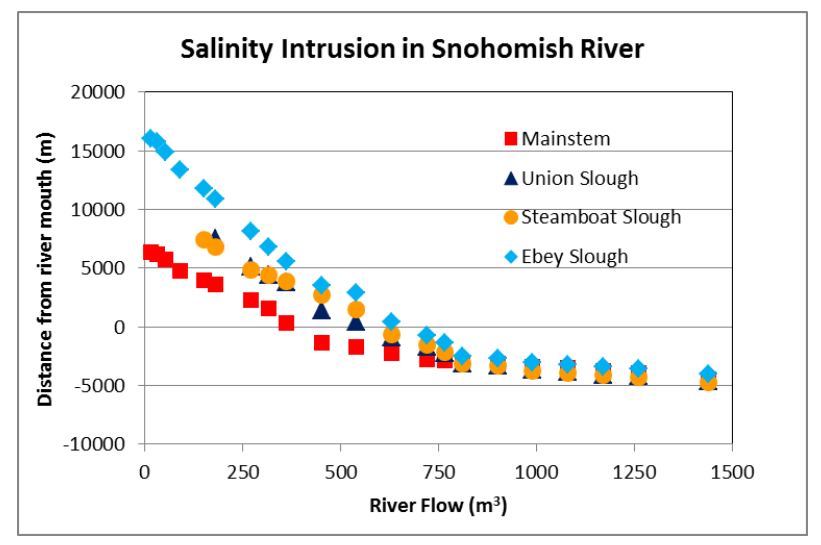

Figure 6-4 Comparison of salinity intrusion points in the distributaries of Snohomish River estuary. The negative values (distances) denote that the (Note: negative distance means the salinity intrusion point is downstream of the river mouth)

\subsection{Inundation and Salinity in the Intertidal Zone and Floodplain}

Inundation areas in the intertidal and floodplain were estimated for current conditions, and under LULC and climate change scenarios. The intertidal zone was defined as the area between high tide and low tide that experiences wetting-drying process during a spring tidal cycle. The area of the floodplain was determined based on the floodplain boundary of the lower Snohomish River estuary defined by the Federal Emergency Management Agency.

Under current conditions, FVCOM runs showed that the area of inundation was decreased by about $10 \%$ when river flow was reduced to the lowest monthly mean of $30 \mathrm{~m}^{3} / \mathrm{s}$. When river flow was increased to $800 \mathrm{~m}^{3} / \mathrm{s}$, the inundation area increased by about $15 \%$. However, as river flow continued to increase and pass $800 \mathrm{~m}^{3} / \mathrm{s}$, there was a sudden jump in the change in inundation area, indicating that at this point, water overtopped the levees along the riverbank and inundated the floodplain area (Figure 6-5). Under low river flow conditions, there is little change in the area of inundation and depth of the water on the floodplain, for both LULC and climate change scenarios. However, changes in LULC and climate result in significant changes in the average salinity in the inundated area under all flow conditions: sometimes raising the salinity, sometimes lowering the salinity. LULC changes show slightly less effect on the area of inundation than does of climate change in the low flow regime but greater effect in the high flow regime. 


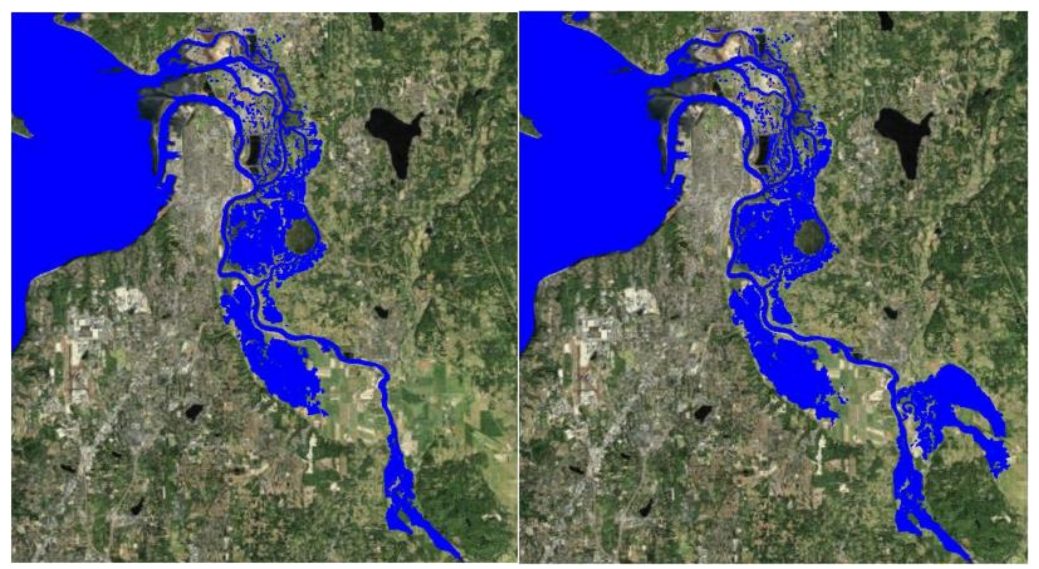

Figure 6-5. Comparisons of inundated areas at low tide for low river flows on left $\left(765 \mathrm{~m}^{3} / \mathrm{s}\right)$ and higher flows on right $\left(810 \mathrm{~m}^{3} / \mathrm{s}\right)$. Both simulations are shown at low tide.

\subsection{Estuarine Response to Sea-Level Rise Scenarios}

Sea-level rise along the west coast of the United States can be attributed to several factors, including changes in wind patterns, gravitational and deformational effects of modern land ice melting, and vertical land motion. The projected relative sea-level rise at Seattle contributed by all these factors is $0.166 \mathrm{~m}$ with an uncertainty of $\pm 0.105 \mathrm{~m}$ for the year 2050 (NRC 2012). The relative sea-level rise will rapidly increase to $0.618 \mathrm{~m}$ with an uncertainty of $\pm 0.293 \mathrm{~m}$ by the end of the century. To look at the effects of sea-level rise on estuarine hydrodynamics, the FVCOM incorporated three sea-level rise projections: $0.325 \mathrm{~m}, 0.618 \mathrm{~m}$, and $0.911 \mathrm{~m}$. Sea-level rise scenarios were simulated under the low, mean, and high monthly average river flow conditions $\left(30,270\right.$, and $\left.810 \mathrm{~m}^{3} / \mathrm{s}\right)$ - a total of nine model runs. The results show that salinity intrusion points, inundated area, as well as average water depth and salinity of the inundated area, all respond linearly to sea-level rise, rising as the pressure of ocean water pushes against the mouth of the estuary.

\subsection{Simulation of Fecal Coliform Fate and Transport}

An investigation of the fate and transport of fecal coliform bacteria was undertaken for stormwater runoff from Everett. This test of the model was simplistic but showed the potential for using this modeling system to examine biological contaminants in stormwater discharge. FVCOM incorporated a module that used a constant concentration of $100 \mathrm{MPN} / 1$ at the point source discharge (City of Everett Combined Sewer Overflow [CSO]), with a decay rate of 1.0 and a settling velocity of $0.00001 \mathrm{~m} / \mathrm{s}$ for the fecal coliforms, at a mean river flow of $270 \mathrm{~m}^{3} / \mathrm{s}$. Preliminary results indicated that the plume of fecal coliforms discharged from City of Everett's CSO is diluted quickly as it moves from the estuary to Possession Sound, resulting in little chance of retaining significant concentrations of fecal coliforms in Port Gardner Bay. Figure 6-6 shows the model output of surface concentrations of fecal coliforms in Port Gardner Bay. 

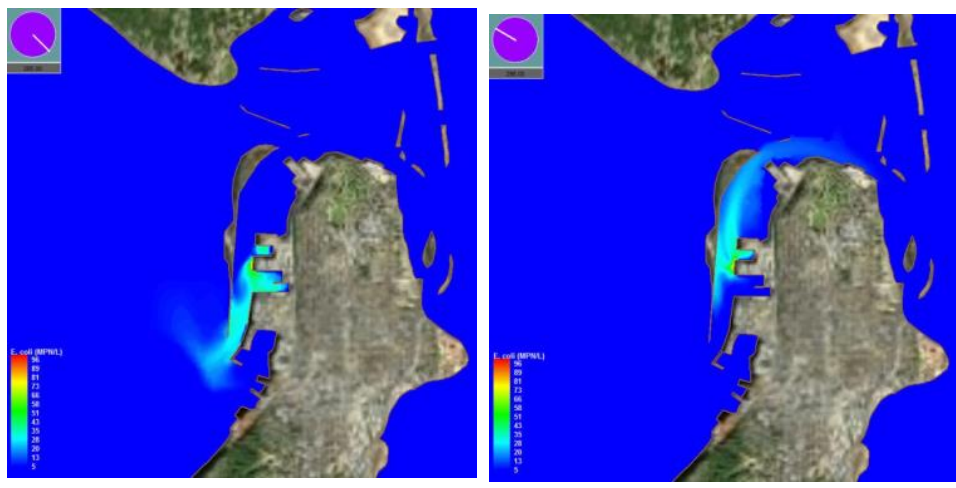

Figure 6-6. Model results showing surface concentrations of fecal coliforms in Port Gardner of the Snohomish River estuary at ebb tide (left) and flood tide (right). 



\subsection{Integrated Water Resource Management System}

The results of the two models used during the analysis phase of this project, DHSVM and FVCOM, were integrated to link simulations of water movement from top to bottom in the Snohomish basin. The idea of linking models is not new; using a traditional modeling approach, the two models would have been integrated as follows:

- DHSVM would be set up, calibrated, and run.

- DHSVM output data would be post-processed to be suitable as input to FVCOM.

- FVCOM would be set up (including the input data from DHSVM), calibrated, and run.

For the Snow Caps to White Caps proof of concept, the number of parameters passed from one model to the other, and the number of intersection nodes, was very small. The traditional linkage approach for models would be adequate to achieve the outcome desired. However, there are many other aspects of model integration that are needed, particularly as the complexity and number of model interactions increases, and the number of parameters and nodes increases. Key among these additional needs are configuration control, documentation, and reproducibility. For this study we used the IWRMS to appropriately link, document, and control the quality of the integrated system, as well as to envision the expansion of Snow Caps to White Caps to a more complex modeling system that could benefit other Puget Sound basins.

\subsection{IWRMS Overview}

The IWRMS was developed by PNNL for the King County Department of Natural Resources and Parks (KC-DNRP) to provide integrated modeling and data-management support for scientific investigations and planning efforts in the Sammamish-Washington and Green-Duwamish watersheds. IWRMS is built on a pre-existing model integration software system called the Framework for Risk Analysis in Multimedia Environmental Systems (FRAMES). FRAMES was developed by PNNL with sponsorship from the U.S. Department of Energy, EPA, U.S. Nuclear Regulatory Commission, and the U.S. Army Corps of Engineers' Engineer Research and Development Center (ERDC), and consists of specific hardware and software.

IWRMS includes components for model integration, an external data harvester, a model integration wizard, data repository with pedigree, analysis/visualization tool integrator, and a study manager. Details of the components of IWRMS and specific hardware and software requirements can be found in Appendix III.

\subsection{Benefits of IWRMS for this Project}

The purpose of using IWRMS for this project was to facilitate the integration of models and the management of data for this proof-of-concept effort, as well as to explore how the system might include additional models, be expanded for use in new geographic areas, and include additional water-quality and habitat parameters. A simplified pathway for the passage of data from DHSVM to FVCOM, and the potential to pass data to and from other models, is shown in Figure 7-1. 


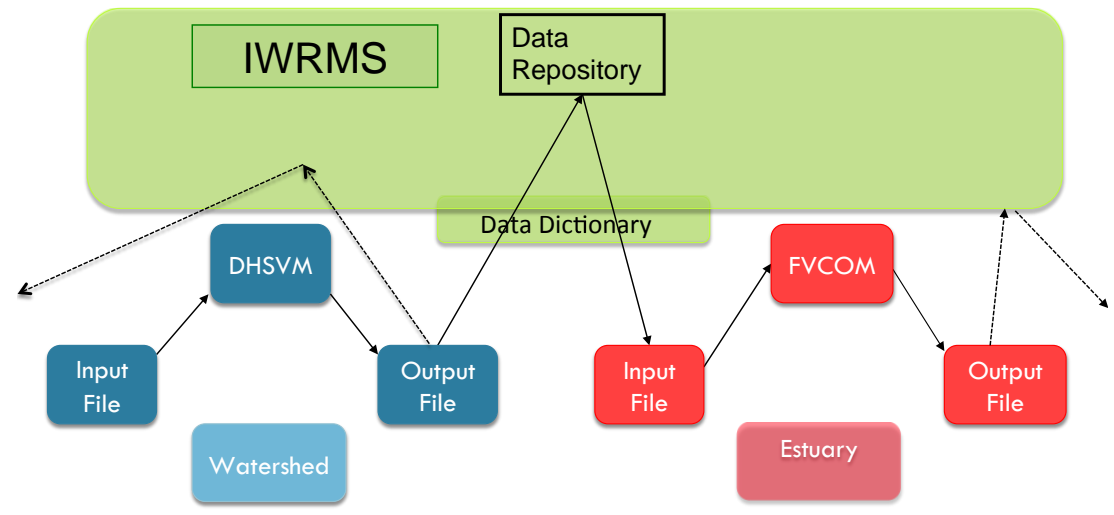

Figure 7-1. Schematic of IWRMS process of passing data from DHSVM to FVCOM, and the potential to pass data to and from other models

Using IWRMS does not ensure that the modeling tasks will be simplified; running a model outside IWRMS will almost always be less complex than within IWRMS. Similarly, the use of a complex model will not become simplified with the use of IWRMS. The benefit of IWRMS is derived from the ease of integration among models and in the structuring of the processing, documenting, and storage of the results. Key aspects of IWRMS that improve the outcome through use of the system include data pedigree, configuration control, documentation, reproducibility, and scenario modeling. Details of each aspect of IWRMS can be found in Appendix III.

\subsection{Use of IWRMS to Support Snow Caps to White Caps}

To adapt IWRMS for use in Snow Caps to White Caps, the hardware and software created for KCDNRP needed to be evaluated, and additional hardware capability and software modifications were required. Processes for adapting the inputs and outputs of DHSVM to fit IWRMS were needed as well as a procedure for executing the data and file transfer. Quality assurance/quality control procedures for ensuring model integrity were carried out in IWRMS. The specifics can be found in Appendix III.

\subsection{Expansion of the Snow Caps to White Caps Concept Beyond the Snohomish Basin}

Snow Caps to White Caps was designed specifically to address questions in the Snohomish basin, and to act as a proof of concept for application of such a system to other basins within Puget Sound. If the system proved useful to resource managers, perhaps a Puget Sound-wide expansion could be considered.

\subsubsection{Potential for Expansion}

For this study, IWRMS was used to integrate DHSVM and FVCOM as a proof of concept for how the system can be applied to hydrologic and coastal modeling studies. Integrated modeling runs for climate change and LULC scenarios showed that the IWRMS can be a powerful tool for integrating the results of hydrologic (watershed) and coastal (estuarine) modeling. The IWRMS application in the Snow Caps to White Caps assessment could easily be modified and extended to integrate multiple additional 
models of land, water, and ocean environments for much more complex and larger systems, such as Puget Sound. Potential alterations and expansions of the system are discussed in the following sections.

\subsubsection{Inclusion of Additional Parameters}

Although IWRMS was used for this study only to pass one parameter between DHSVM and FVCOM (water flow), IWRMS is not limited to a specific number of parameters that can be passed between models. Using the current pair of models (DHSVM and FVCOM), additional parameters such as temperature, sediment, nutrients, and other water-quality parameters could be added to examine effects of the future scenarios in more detail and/or to answer related questions. Making this leap would not be difficult because versions of DHSVM have been developed to include several of these parameters. However, none is sufficiently validated and quality-assured to cover the Snohomish basin at this time. FVCOM is a powerful model and includes modules for many water-quality and chemical contaminant parameters that could be tailored to accept information of this type from DHSVM. IWRMS could play the role of organizing, linking, and archiving the results and making them accessible.

\subsubsection{Use of Different Models}

The flexibility of IWRMS ensures that the use of a variety of models now and in future will remain coherent, organized, and well documented. This will assure water resource managers that they can rely on comparisons and trends in data as future conditions prevail.

Because the models operate as black boxes within IWRMS, different watershed and estuarine models could be used. For example, HSPF (a widely used watershed model) could be substituted for DHSVM. Similarly ROMS (a widely used ocean model) could be substituted for FVCOM. The models chosen for this study were considered to be the best suited and most appropriate to answer questions posed in the Snohomish basin; however, other questions might require the use of other models best suited to the task. In addition, researchers or managers who are most comfortable with a particular model might choose to use it, rather than incur the overhead task of setting up and learning a new modeling framework. Similarly, as new and better models are developed, IWRMS can quickly and easily substitute them for the previous models, keeping track of older model outputs as well as newer information.

\subsubsection{Expanding the Geographic Extent}

This study looked specifically at watershed and estuarine processes in the Snohomish basin and applied the appropriate modeling tools. Researchers conducting other studies might desire to use the Snow Caps to White Caps system in another Puget Sound basin. Fortunately both DHSVM and FVCOM have been developed and validated for the whole Puget Sound watershed and adjacent estuarine and coastal waters, allowing the system to be transported readily. Additionally, the IWRMS system could be used to integrate DHSVM and FVCOM for a Puget Sound-wide assessment. 


\subsubsection{Addition of Other Model Types}

For the Snow Caps to White Caps proof of concept, the questions addressed how future changes in climate and LULC might affect the flow and other water-based characteristics in the system. The models chosen (DHSVM - watershed; FVCOM - estuary and floodplain) were best suited to simulate those relationships. However, IWRMS is not limited to linking and organizing models that describe watersheds and estuaries. Other key questions that might be addressed in the Snohomish or other basins of Puget Sound, and the model genres that might be used in conjunction with watershed and estuarine models to address them, include the following:

- How will future LULC and climate changes affect wetland recharge and salmon survival? Models might include groundwater hydrology, terrestrial and aquatic ecosystem, and fish survival models.

- How will individual basins in Puget Sound vary in their hydrologic and estuarine response to climate change? Models might include a variety of atmospheric and ocean climate models that will tailor the downselect of global climate change models more specifically than the IPCC scenarios used in this study.

- What effect will LULC and/or climate changes in the basin have on estuarine food webs, with an emphasis on commercial species? Models might include food web models that examine the lower river and estuary as well as marine food web and ecosystem models.

- What effect will LULC and climate changes have on the carbon budget in the near coastal ocean and ocean acidification levels in Puget Sound? Models might include carbon budget, ocean acidification, and ecosystem models.

- How will climate change and resulting changes in stormwater from the watershed affect nearshore infrastructure? Models might include probabilistic sea-level rise models, modules that add contaminants to watershed runoff models, and geospatial models that simulate present and future placement of key infrastructure.

- How will climate and LULC changes and subsequent flooding affect the success of farming in the floodplain? Models might include detailed inundation models and socioeconomic models.

In each case, the additional or substituted models could be brought into IWRMS and the results made available to answer questions of importance to land and water management in the region.

\subsubsection{Alternate Modeling Scenarios}

For this study, specific environmental conditions and assumptions were made to answer the questions posed, and the appropriate number of model runs were carried out to provide sufficient power for statistical analysis. To answer other questions, working with data of different resolution, it might be necessary to increase the number of model runs dramatically. IWRMS can organize, track, link, and archive very large numbers of model runs to support expansion of the system. 


\subsection{Outreach and Feedback}

A key element for the success of this project was the interactions with water resource managers at the inception and throughout the model development and integration phase (see Section 4.0, Management Questions Driving Research). Of equal importance is sharing the results of the analysis at key points in the process.

Formal outreach for Snow Caps to White Caps will be bookended by presentations at two Salish Sea conferences:

- 2011 Salish Sea Ecosystem Conference in Vancouver B.C., October 2011. The PNNL/UW project team presented a paper entitled: Snow Caps to White Caps: Numerical Modeling in the Snohomish Basin to Assist Resource Managers in a session on numerical models of land and sea. The session was well attended and our paper sparked a lot of questions and follow-up discussions.

- 2014 Salish Sea Ecosystem Conference in Bellingham, Washington, April-May 2014. Our team will present the final results of the project.

PNNL project staff were invited to participate in a forum on the Future of Puget Sound in March 2013, led by the Urban Ecology Laboratory at the University of Washington. We presented a poster on Snow Caps to White Caps.

In addition to meeting with the project partners during the course of the project, as the final results have become available meetings were held to share them with Snohomish County Surface Water Management, King County Natural Resources and Parks, and the Tulalip Tribes, as well as the Snohomish Basin Recovery Planning Committee. PNNL staff will present results to the Snohomish County Marine Resources Committee in January 2014, and plan a meeting with the City of Everett in January 2014 as well. We also plan to hold additional meetings with agency staff at the state and federal level. 


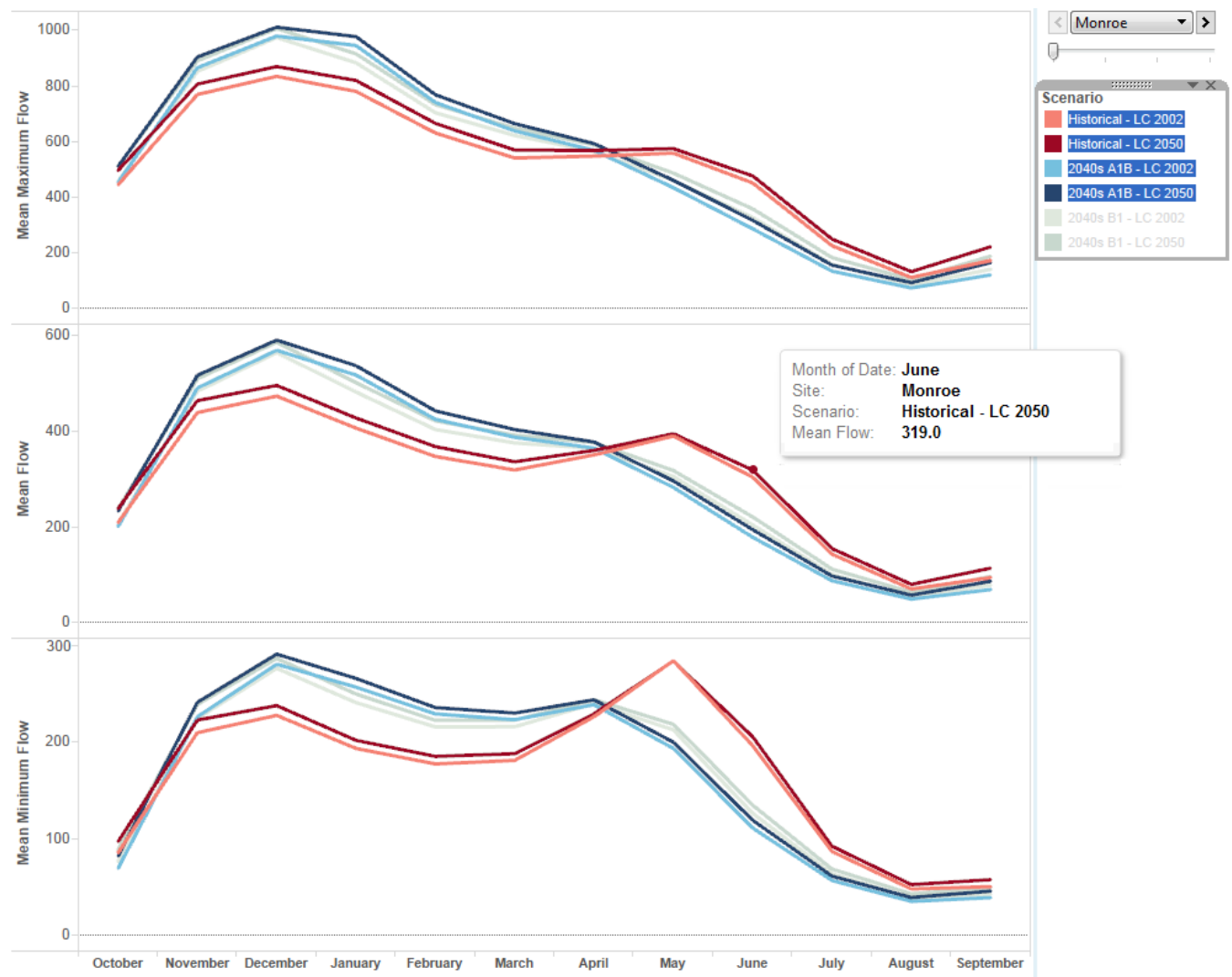

Figure 8-1. This figure represents an example of how the hydrographic curve will change from historical to future conditions, generated using Tableau. In this panel, the hydrograph is shown for Monroe under conditions of maximum flow (top), minimum flow (middle) and mean flow (bottom), over the water year. The colored lines represent the different land use and climate scenarios. The timing, flows, and location can be altered by the user to view how they will affect the timing and peak of the hydrograph.

A series of powerpoint presentations and other outreach materials have been prepared, including interactive images of modeling results, using a visual utility called Tableau. The interactive Tableau graphics allow a user to make changes to input parameters and to see the resulting changes in the output. Figure 8-1 shows an example of a hydrographic curve that has been altered, based on different user inputs. Figure 8-2 shows an example of the changes in upriver salinity intrusion points under different riverflow conditions. We are currently looking for a site to host the images and interpretation following the end of the EPA-funded project.

We anticipate a minimum of two and perhaps more journal articles will result from this project. 


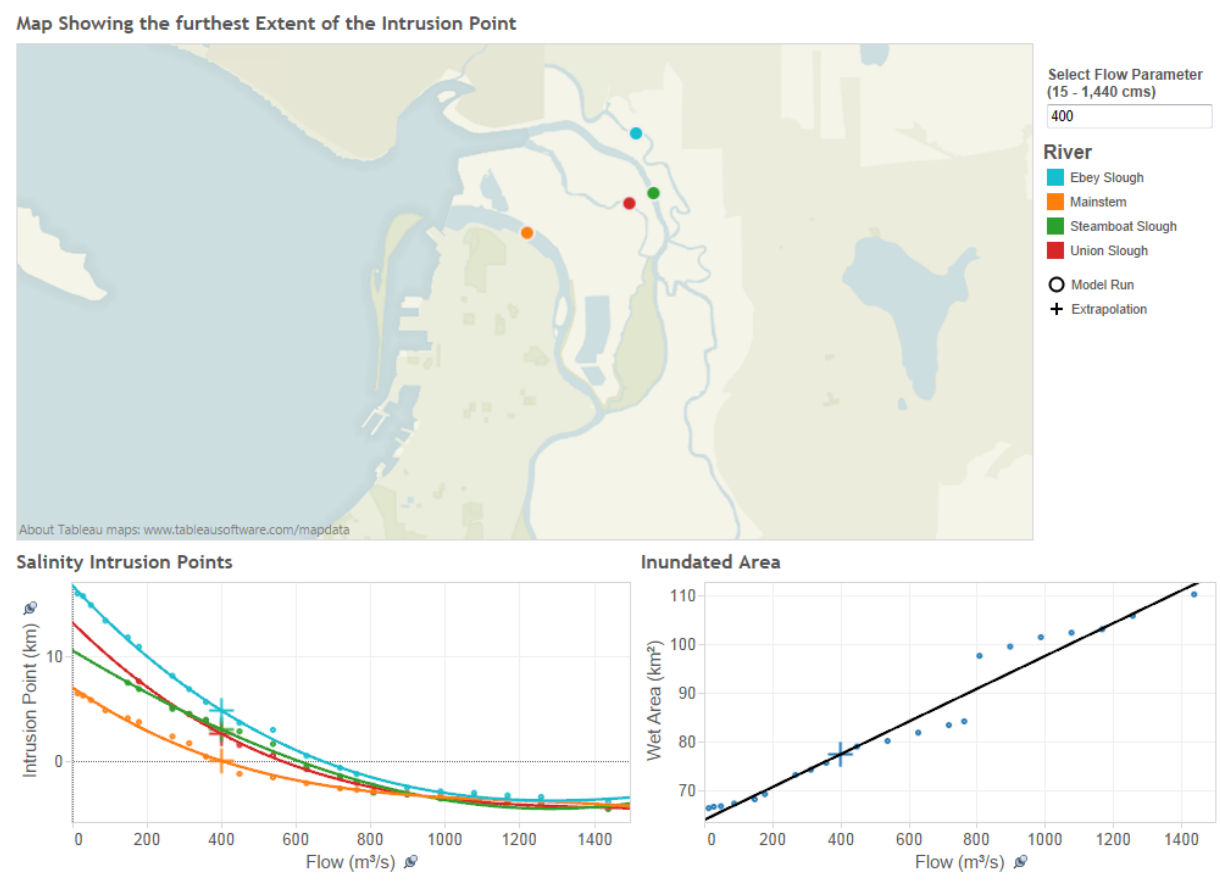

Figure 8-2. An example from Tableau that shows the extent of the salinity intrusion point up the Snohomish River and distributaries and the inundated area of the floodplain, under different riverflow conditions, created due to changes in climate and LULC. The user can vary the river flow to investigate the manner in which the intrusion points and inundated areas will differ. 



\subsection{Putting It All Together}

The PNNL and UW project team set out to investigate the use of an integrated modeling system to examine future scenarios for climate and LULC change in the Snohomish basin, using water as a currency from the highest mountain reaches to the river mouth and estuary entering Puget Sound. We asked local water resource and salmon managers what issues concerned them and what support they felt they might need in the next 5 years or so. From those needs, we devised a set of questions and set out to develop the integrated modeling system that could help to answer them (Figure 9-1). We found several interesting relationships for selected parts of the watershed, floodplain, and estuary, and examined how they might relate across the basin and over time. We checked in with our water resource management partners several times throughout the project and are sharing the results with them as the project draws to a close.

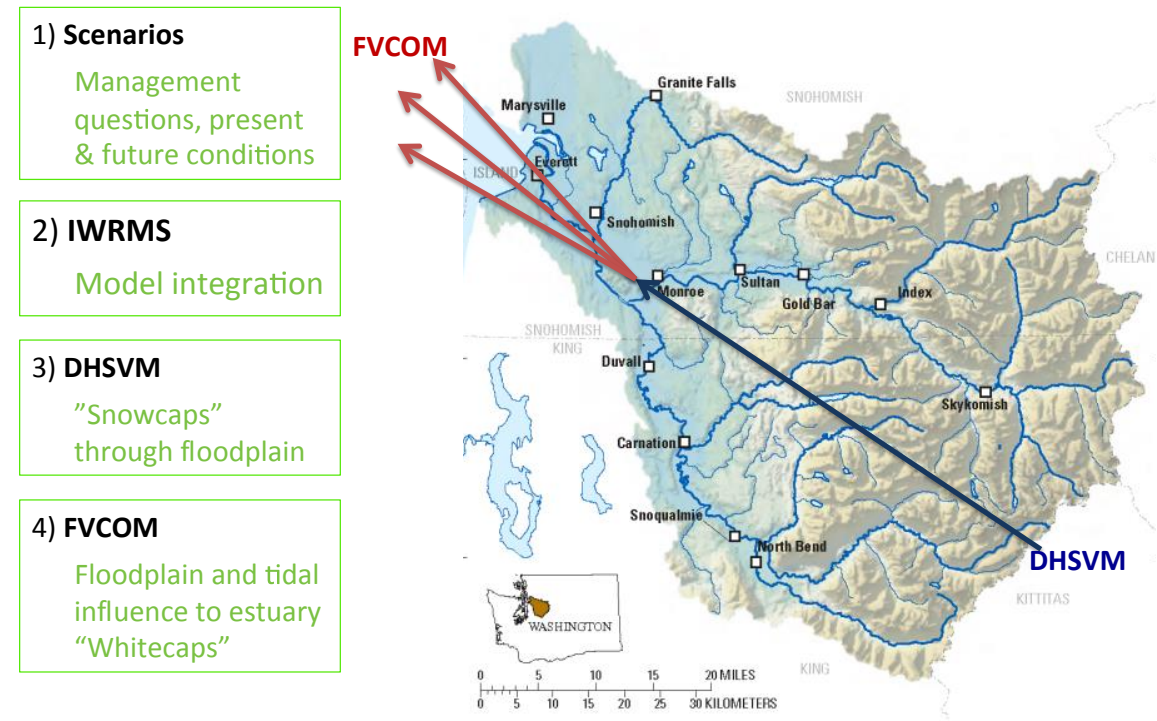

Figure 9-1. Schematic of planning and model integration for Snow Caps to White Caps.

\subsection{Application of LULC and Climate Scenarios}

To examine potential futures for the Snohomish basin using the integrated modeling system, the project team chose future scenarios that represent the future changes for which sufficient understanding and data are available to use in modeling studies. Along the way, we discarded many other scenarios as being indefensible and/or for which knowledge of potential interactions with waterflow in the basin is not available. The scenarios upon which we settled were credible (for example, the IPCC scenarios for climate change) and were closely linked to management actions in the basin (for example, the LULC layers representing conversion of land from forest to residential or agricultural land, and the conversion of agricultural land to urban/suburban settlements). Table 9.1 summarizes the scenarios and indicates the questions for which each was applied. 
Table 9.1. Scenarios chosen for integration into modeling framework, aimed at examining questions of interest to water resource managers.

\begin{tabular}{|c|c|c|}
\hline $\begin{array}{c}\text { Scenario } \\
\text { Type }\end{array}$ & Scenario Descriptor & Application \\
\hline $\begin{array}{l}\text { Climate } \\
\text { change }\end{array}$ & Historical condition & $\begin{array}{ll}\text { - } & \text { Effect of flow on basin } \\
\text { - } & \text { Forestry practices } \\
\text { - } & \text { Effects on flooding } \\
\text { - } & \text { Salinity intrusion }\end{array}$ \\
\hline $\begin{array}{l}\text { Climate } \\
\text { change }\end{array}$ & $\begin{array}{l}\text { A1B } \\
\text { (balance between fossil } \\
\text { fuel and renewable energy } \\
\text { technologies) }\end{array}$ & $\begin{array}{ll}\text { - } & \text { Effect of flow on basin } \\
\text { - } & \text { Forestry practices } \\
\text { - } & \text { Effects on flooding } \\
\text { - } & \text { Salinity intrusion }\end{array}$ \\
\hline $\begin{array}{l}\text { Climate } \\
\text { change }\end{array}$ & $\begin{array}{l}\text { B1 } \\
\text { (clean energy } \\
\text { technologies) }\end{array}$ & $\begin{array}{ll}\text { - } & \text { Effect of flow on basin } \\
\text { - } & \text { Forestry practices } \\
\text { - } & \text { Effects on flooding } \\
\text { - } & \text { Salinity intrusion }\end{array}$ \\
\hline LULC & Historical (2002) & $\begin{array}{ll}\text { - } & \text { Effect of flow on basin } \\
\text { - } & \text { Effects on flooding } \\
\text { - } & \text { Salinity intrusion }\end{array}$ \\
\hline LULC & 2050 & $\begin{array}{ll}\text { - } & \text { Effect of flow on basin } \\
\text { - } & \text { Effects on flooding } \\
\text { - } & \text { Salinity intrusion }\end{array}$ \\
\hline LULC & 2007 Business as Usual & - Forestry practices \\
\hline LULC & 2007 Mature & - Forestry practices \\
\hline
\end{tabular}

\subsection{Questions Addressed by Snow Caps to White Caps}

Discussions with water resource managers (Section 4.0 of this report) helped the project team hone the overall direction of the project with an integrated vision for an accurate spatial and temporal understanding of freshwater flows throughout the watershed, and the translation of those flows into the estuary. The system was to be tested for likely futures under the twin pressures of climate change and changes in the human footprint within the basin.

With the vision of an integrated picture of water flow over time and space in the Snohomish basin, we honed in on more specific management questions that are of importance to our team partners charged with managing natural resources. These questions and our approach are described here.

\subsubsection{Pressure Caused by Changes in Climate and LULC on Salmon Viability}

We heard concerns from many resource managers about the future integrity of the overall Snohomish basin, with particular emphasis on maintaining river flows for Pacific salmon. Salmon populations are under pressure from many aspects of climate change, from ocean acidification, changes in run timing and retention in the river and lower estuary with changes in water temperature, to changes in food availability from ecosystem alteration (McDaniels et al. 2010; Beamish and Mahnken 2001; Hare and Francis 1994). 
Future climate predictions and additional pressure from LULC changes are likely to add additional burdens that will further stress the fish. The Tulalip Tribes have major concerns about run timing and how best to operate their hatcheries. Snohomish and King county fisheries managers worry that investments in habitat restoration may not be optimally sited or may prove ineffective.

Our project team addressed these holistic questions in the watershed, the floodplain, and the estuary as follows:

Watershed -

- DHSVM was further validated throughout the Snohomish basin to ensure that the flows are accurate under historical and future flow conditions.

- New LULC layers were added to more accurately describe the vegetative cover of the basin, allowing managers to understand natural stream temperature regulation that affects migrating salmon.

- Statistics for multiple aspects of flow under future LULC and climate scenarios were examined to determine low flow conditions and recurrence under each future scenario.

- Model outputs for flow at Monroe were handled through IWRMS to ensure they met requirements for input to FVCOM for the floodplain and the estuary, to accurately predict flows in the lower estuary.

Floodplain and estuary -

- The FVCOM grid was refined to optimize the resolution in the floodplain to ensure the accuracy of predictions for the area inundated.

- Climate change scenarios were augmented with model inputs for sea-level rise, to accurately model the inundation area and salinity of the floodplain.

- The salinity intrusion point under each future scenario over a complete monthly tidal cycle was resolved to understand the salinity regime that downmigrating juvenile salmon will face.

The outcome of the modeling analyses indicates that while the overall flow in the river on an annual basis, and the overall extent of flooding, may not be significantly altered under the LULC and climate change futures tested, the timing is likely to be changed considerably. The implication for when to release hatchery salmon upstream to ensure their best survival is likely to need further scrutiny on a subbasin by subbasin basis; the DHSVM results can further help to pinpoint the basins of greatest interest, but specifics for locations with salmon hatcheries were not examined.

The timing and extent of salinity intrusion derived from FVCOM can be used by fisheries biologists to understand the potential changes in retention time for downmigrating salmon in the lower river, an important feature associated with the life history of runs in the Snohomish (Snohomish Basin Salmon Recovery Forum 2005). Examining the effects of sea-level rise on the flow in the river also raises questions about whether nearshore habitats of importance to juvenile salmon in Possession Sound might be compromised. While this project did not examine scenarios associated with nearshore Puget Sound habitat, the FVCOM model runs could be extended in future to address this question. 


\subsubsection{Extent of Flooding that Will Occur in the Lower Reaches of the Watershed due to Climate Change and Population Growth}

Surface-water and salmon managers in the Snohomish basin are concerned about the extent of flooding in the lower watershed under changing conditions. Surface-water managers must worry about potential damage to human safety and property; infrastructure such as roads, bridges and pipelines; damage to private property; and the investments and technologies needed to reroute, treat, and discharge the floodwaters. Salmon managers worry that floodwaters may disturb natural migratory patterns for salmon, destroy egg nests in the lower river, and wash away food sources for young salmon that spend time maturing in the lower river. The use of agricultural lands that make up a significant portion of the floodplain may suffer from inundation, particularly if salinity levels peak, depositing salts on the soils as the floodwaters retreat. Ironically, waterfowl and other wildlife (perhaps even juvenile salmon) will benefit from additional flooded areas.

The project team, working through the IWRMS connection, faced these questions as follows:

Watershed -

- DHSVM contributions were focused on ensuring accurate spatial and temporal flows driving the hand off of data to FVCOM at Monroe, the start of the floodplain.

Floodplain and estuary -

- FVCOM modelers focused on balancing the timing and flows of water from upstream in the river with the tidal influence in the lower estuary, particularly under climate change scenarios.

- The extent of inundation and overtopping of levees were calculated for each condition of flow, as were the depth of water and salinity in the flooded areas.

Armed with the projections for changes in climate and LULC, water resource managers can further develop the two-pronged approach to change: adaptation and mitigation. Stormwater managers can support adaptation by working with other county agencies to plan for the necessary infrastructure to protect and process floodwaters; plan for emergency services; institute floodproofing measures for roads, bridges, and pipelines; and create education programs that will help nearby residents and business understand the potential threats. Mitigation measures most readily available to resource managers can be found in the differentiation of effects between LULC and climate changes; LULC changes are under the control of elected officials and resource managers, but climate conditions are not. We know that river flows under LULC and climate scenario have an effect on the salinity on the floodplain, and that LULC has a greater effect than climate change under high flow conditions. By understanding where in the watershed or floodplain the greatest damage may be done with further development in the basin, managers may be able to slow the processes that converting agricultural land to impervious surface and forestland to other uses, resulting in smaller effects than predicted by the 2050 LULC scenarios. Similarly, the modeling results will help to inform the need for changes in nearshore infrastructure, including retreat and rebuilding of major industrial facilities, as well as setbacks for residential properties.

Salmon managers, public works directors, elected officials, and farmers have the opportunity to understand potential damage that may occur under future scenarios, allowing for thoughtful planning and investment against the coming conditions. 


\subsubsection{Effects of Specific Forest Management Practices in the Upper Watershed on the Hydrology of the Basin}

Snohomish and King county resource managers asked very specific questions about the effects of forest practices on the river flow and timing of flooding for the upper watershed. They must make fundamental decisions about how much logging to permit, particularly on steep slopes in the snowy upper reaches. The project team addressed these questions as described below.

The LULC layers developed to examine the Snohomish basin as a whole (2002-historical condition; 2050-future condition) were too crude to address as specific a question as that of the effects of forest practices. The PNNL and UW team developed a new layer of LULC for 2007, understanding that significant changes in the watershed had taken place between 2002 and 2007, and parsed that layer into the Business as Usual case, and the Mature case. By resolving the differential stream-flow statistics between the two conditions (Business and Usual and Mature), the modelers looked at the effects of forest practices in the subbasins in the forested area of the basin. In the south fork of the Skykomish they found that harvest activities will increase the overall flow significantly but will not alter the timing of the hydrograph, while in the subbasin at the north fork of the Snoqualmie, the timing of the hydrograph will not change but the overall flow will increase in the river.

By examining the effects of LULC and climate changes on the two forested subbasins and two others lower in the watershed, the project team was able to reach some conclusions about the relative effects of the two forcing functions on river flow (Table 5.1 and Table 5.2). This information will assist water resource and forestry managers in planning for allocating harvest limits to specifc subbasin types, particularly as climate change affects the timing of snowmelt, changing many snow-dominated subbasins to transition and rain-dominated ones.

There was no involvement with FVCOM or IWRMS in answering these questions.

\subsubsection{Fate and Effects of Biological Contamination in Marine Waters}

City of Everett stormwater managers were particularly interested in the fate of fecal coliforms that are washed into stormwater and ultimately into Port Gardner Bay. The public has postulated that contaminated shellfish beds along the periphery of Port Gardner Bay are closed to shellfish harvest due to inappropriate handling of stormwater by the city. Our team approached this question as described below.

FVCOM has water-quality and other biological and chemical contaminant modules built in. PNNL modelers activated a module that allowed them to simulate the input of fecal coliforms into the outfall of stormwater from the City of Everett. Based on the simple modeling effort with a constant fecal load and flow, an estimated decay rate and settling of the bacteria, it appears that any measurable fecal load that enters the bay will be dispersed rapidly within one tidal cycle and is unlikely to be the source of the contamination of shellfish beds at the extent of the bay.

This information will provide the city with a reasonable first cut with which to address the perception of fecal spread from stormwater, but also points to a methodology that could be further enhanced and validated to ensure that current and future loads of contaminants are not affecting valued resources. 
DHSVM outputs did not affect the outcome of this analysis, other than providing accurate inputs of flow to FVCOM at Monroe. 


\subsection{Summary and Conclusions}

Through this project, the Snow Caps to White Caps concept has been tested, as a means of applying an integrated modeling system to questions raised by water resource managers. The Snohomish basin, home to important Pacific salmon runs and other freshwater and marine organisms, as well as a secure and prosperous location for human settlement, provided an optimum system to inventory and explore the distribution, timing, and movement of freshwater and saltwater that define the integrity of the basin.

\subsection{Answering Management Questions}

Project partners, including staff from Snohomish and King counties, and the City of Everett, and other resource managers in the region, provided clear and pertinent questions to the research team at PNNL and UW. The water resource managers were thoughtful in considering what their medium- to long-term information needs will be under the twin threats of climate change and expanding human development in the basin. With their help, the research team was able to translate those needs into hypothesis-based questions; these questions helped to frame the enhancements that were needed to the two key models (DHSVM and FVCOM) to provide useful statistics and model outcomes. The linkage, documentation, quality control, and archiving functions provided to the modeling system by IWRMS ensured that the system is transparent and reproducible. In particular, using IWRMS allows for expansion of the system with more parameters, the addition of models of many genres, and the portability of the system to other basins within Puget Sound, as well as to the entire Puget Sound basin.

The output of the modeling system can provide greater certainty in stream flow and estuarine water movement forecasts, allowing water resource managers to more accurately predict the timing and extent of flooding; improve stormwater management; plan for future potable water supplies; and optimize the timing of hatchery salmon releases. By applying the output of the watershed and estuarine models, natural resource manager will have greater certainty in planning for successful habitat restoration projects, and will have additional tools to optimize selection of salmon habitat restoration sites for mitigation of losses. The outputs from this project and further iterations can be used to create land-use management tools, including input to comprehensive plan changes, and visualization products for outreach to elected officials and the public.

\subsection{Next Steps}

This project completed the proof of concept for Snow Caps to White Caps; to realize the capability of the system, more work is needed. Expansion of the system could be achieved along multiple axes, as described below.

\subsubsection{Expansion within Snohomish Basin}

A very limited number of subbasins within the Snohomish were examined during this project to address specific questions about forest management practices. Additional subbasins could be examined with additional model runs, subject to the availability of appropriate validation data, to answer other questions. Such questions might include the effects of urbanization on stream flows, interaction of 
permanent and ephemeral wetlands on flow timing, the role of agricultural land conversion on peak hydrographs, and effectiveness of salmon restoration projects on providing adequate flows for fish.

\subsubsection{Addition of Parameters}

DHSVM provided water flow as the only parameter for this study; FVCOM added temperature and salinity to the floodplain and estuary. Additional parameters of environmental significance that could be modeled throughout the system include water temperature, dissolved gases (oxygen, carbon dioxide), dissolved nutrients (nitrates, ammonia, phosphate, silicate), and heavy metal and organic contaminants (lead, cadmium, copper, PAHs, PCBs, PBDEs, etc.). Both models are capable of handling these parameters and could be enhanced to address specific concerns with appropriate validation data and additional modules set up.

\subsubsection{Addition of Models}

Applying the modeling system to other questions could also be readily accomplished through the addition of other models through IWRMS. For example, specialized flood-prediction and -management models to examine flood characteristics in more detail such as HEC-RAS or LISFLOOD-FP; ecosystem models that delineate movement of energy through the food chain such as EcoPath; chemical risk assessment models that quantify the level of contaminants in the aquatic environment such as MONERIS.

\subsubsection{Expansion to Other Basins}

The Snohomish basin was an ideal location for this study because researchers have worked with DHSVM and FVCOM in the basin; there were sufficient validation data available; the pace of development and concern for salmon in the basin is prompting elected officials and managers to take action; and resources managers are actively looking for science-based solutions. The system is readily portable to several other Puget Sound subbasins that display similar attributes, such as the Stillaguamish, Skagit, and Nisqually. Other subbasins in the Sound could also be the subject of expansion, although additional validation data might need to be collected to ensure the accuracy of the models.

\subsubsection{Puget Sound Basin}

Both DHSVM and FVCOM models have been applied across the entire Puget Sound basin; expansion of the Snow Caps to White Caps systems across the basin is feasible. Although many questions that water resource managers face in their jurisdictions are local or confined to a single basin, there are many commonalities among those needs as well. An approach that allows modeling of the basin in an integrated manner from the highest peaks into the marine waters could assist state resource managers in assessing progress toward Puget Sound restoration goals, and provide a benchmark against which to measure effects of climate and human development in years and decades to come. 


\subsection{References}

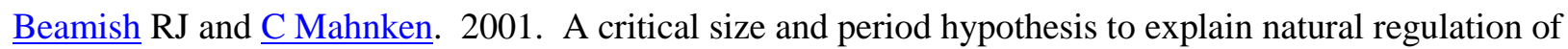
salmon abundance and the linkage to climate and climate change. Progress Ocean. 49(1-4):423-437

Bowling, LC, P Storck, and DP Lettenmaier. 2000. Hydrologic effects of logging in Western Washington, United States. Wat. Resour. Res. 36:3223-3240.

Chen C, H Liu, and RC Beardsley. 2003. An unstructured, finite-volume, three-dimensional, primitive equation ocean model: application to coastal ocean and estuaries. J.Atmospheric Ocean. Technology 20:159-186.

Chen C, Z Lai, RC Beardsley, Q Xu, H Lin, and NT Viet. 2 012. Current separation and upwelling over the southeast shelf of Vietnam in the South China Sea. J. Geophys. Res. 117:C03033, doi: 10.1029/2011JC007150

Cuo L, TK Beyene, N Voisin, F Su, DP Lettenmaier, M Alberti, and JE Richey. 2011. Effects of midtwenty-first century climate and land cover change on the hydrology of the Puget Sound basin, Washington. Hydrol. Process. 25:1729-1753. doi: 10.1002/hyp.7932

Cuo L, DP Lettenmaier, M Alberti, and JE Richey. 2009. Effects of a century of land cover and climate change on the hydrology of Puget Sound basin. Hydrological Processes 23:907-933.

Cuo L, DP Lettenmaier, BV Mattheussen, P Storck, and M Wiley. 2008. Hydrological prediction for urban watersheds with the Distributed Hydrology-Soil-Vegetation Model. Hydrological Processes 22(21):4205-4213. DOI: 10.1002/hyp.7023.

Dukhovskoy DS and SL Morey. 2011. Simulation of the Hurricane Dennis storm surge and considerations for vertical resolution. Natural Hazards 58:511-540

Elsner MM, L Cuo, N Voisin, JS Deems, AF Hamlet, JA Vano, KEB Mickelson, SY Lee, and DP Lettenmaier. 2010. Implications of 21st Century climate change for the hydrology of Washington State. Climatic Change 102(1-2): 225-260, doi:10.1007/s10584-010-9855-0

Greene CM, and TJ Beechie. 2004. Consequences of potential density-dependent mechanisms on recovery of ocean-type chinook salmon Onchorhynchus tshawytscha. Can. J. Fish. Aquat. Sci. 61:590602.

Hare SR and RC Francis. 1994. Climate change and salmon production in the northeast Pacific Ocean, p. 357-372. In R. J. Beamish [ed.] Climate Change and Northern Fish Populations. Can. Spec. Publ. Fish. Aquat. Sci. 121.

McDaniels T, S Wilmot, M Healey, and S Hinch. 2010. Vulnerability of Fraser River sockeye salmon to climate change: a life cycle perspective using expert judgments. J. Environ. Manage. 2010 Dec. 91(12):2771-2780. doi: 10.1016/j.jenvman.2010.08.004.

National Research Council (NRC). 2012. Sea-Level Rise for the Coasts of California, Oregon, and Washington: Past, Present and Future. Committee on Sea-level Rise in California, Oregon, and Washington. Board on Earth Sciences and Resources and Ocean Studies Board. The National Academies Press, Washington, D.C. 
Palmer R, M Wiley, E Korb, J Battin, M Ruckelshaus, K Bartz, and H Imaki. 2010. Modeling Climate Change and Land Use Impacts on Salmon Recovery in the Snohomish

River Basin. http://cses.washington.edu/cig/res/ae/snohomish.shtml

PSP (Puget Sound Partnership). 2010. State of the Sound: A report on Puget Sound ecosystem status and a performance management system to track Action Agenda implementation. Puget Sound Partnership, Olympia, Washington.

Rego JL and C Li. 2010. Storm surge propagation in Galveston Bay during Hurricane Ike. J. Mar Sys. 82(4):265-279

Schnorbus M and Y Alila. 2004. Forest harvesting impacts on the peak flow regime in the Columbia Mountains of southeastern British Columbia: An investigation using long-term numerical modeling, Water Resour. Res. 40:W05205, doi:10.1029/2003WR002918.

Scheuerell MD, R Hilborn, RM Ruckelshaus, KK Bartz, KM Lagueux, A Haas, and K Rawson. 2006. The shiraz model: a tool for incorporating anthropogenic effects and fish-habitat relationship in conservation planning. Can. J. Fish. Aquat. Sci. 63:1596-1607.

Snohomish Basin Salmon Recovery Forum. 2005. Snohomish River Basin Salmon Conservation Plan. Snohomish County Department of Public Works, Surface Water Management Division. Everett, Washington.

Storck P, L Bowling, P Wetherbee, and D Lettenmaier. 1998. Application of a GIS-based distributed hydrology model for prediction of forest harvest effects on peak stream flow in the Pacific Northwest. Hydrol. Process.12:889-904.

SSF Steering Committee. (2009). Sustainable Snohomish Futures Demonstration Project Report. Snohomish County, Everett Washington.

Vano JA, N Voisin, L Cuo, AF Hamlet, MM Elsner, RN Palmer, A Polebitski, and DP Lettenmaier. 2010. Climate change impacts on water management in the Puget Sound region, Washington, USA. Climatic Change 102(1-2): 225-260, doi:10.1007/s10584-010-9846-1.

Wigmosta MS, L Vail, and DP Lettenmaier. 1994. A distributed hydrology-vegetation model for complex terrain. Wat. Resour. Res. 30:1665-1679.

Wigmosta MS, B Nijssen, and P Storck. 2002. "The Distributed Hydrology Soil Vegetation Model." Chapter 2 in Mathematical Models of Small Watershed Hydrology and Applications, VP Singh \& DK Frevert (eds), pp. 7-42. Water Resources Publications, Highlands Ranch, Colorado.

Xing J, AM Davies, and E Jones. 2012. Influence of sea surface wind wave turbulence upon wind induced circulation, tide-surge interaction and bed stress. Ocean Dynamics 62:1017-2042

Yang Z and T Khangaonkar. 2009. Modeling Tidal Circulation and Stratification in Skagit River Estuary Using an Unstructured Grid Ocean Model. Ocean Modelling 28:34-49. doi:

10.1016/j.ocemod.2008.07.004. 
Yang Z, T Khangaonkar, M Calvi,and K Nelson. 2010. Simulation of Cumulative Effects of Nearshore Restoration Projects on Estuarine Hydrodynamics. Ecol. Model. 221: 969-977. doi:

10.1016/j.ecolmodel.2008.12.006.

Yang Z, T Wang, T Khangaonkar, and S Breithaupt. 2012. Integrated Modeling of Flood Flows and Tidal Hydrodynamics over a Coastal Floodplain. J. Env.Fluid Mechanics 12: 63-80. DOI:

10.1007/s10652-011-9214-3.

Yang Z and T Wang. 2013. Tidal Residual Eddies and Their Effect on Water Exchange in Puget Sound. Ocean Dynamics 63:995-1009. doi: 10.1007/s10236-013-0635-z.

Zhao L, C Chen, and G Cowles. 2006. Tidal flushing and eddy formation in Mount Hope Bay and Narragansett Bay: an application of FVCOM. J. Geophys. Res. 111: C10015, doi:10.1029/2005JC003135. 

11.1 




\section{Distribution}

No. of

Copies

\# Name

Organization

Address

City, State and ZIP Code

\# Organization

Address

City, State and ZIP Code

Name

Name

Name

Name

Name (\#)

\# Name

Organization

Address

City, State and ZIP Code
No. of

\section{Copies}

\# Foreign Distribution

\# Name

Organization

Address

Address line 2

COUNTRY

\# Local Distribution

Pacific Northwest National Laboratory

Name

Name

Mailstop

Mailstop

Name

Mailstop

Name

Mailstop

Name

(PDF) 




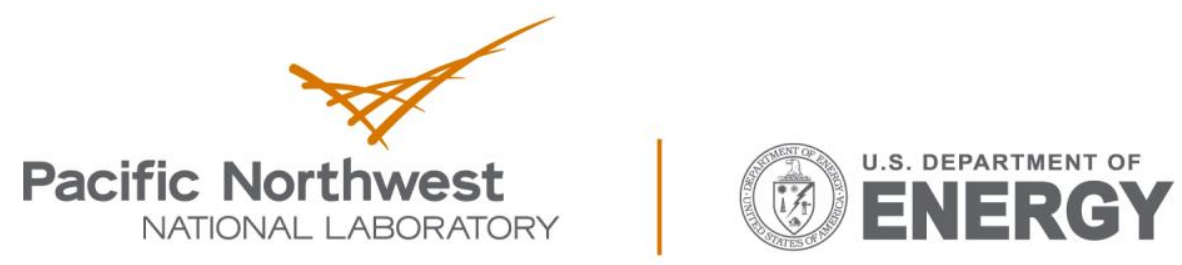

Proudly Operated by Battelle Since 1965

902 Battelle Boulevard

P.O. Box 999

Richland, WA 99352

1-888-375-PNNL (7665)

www.pnnl.gov 


\section{Appendix I. Watershed Hydrology under Climate Change and Land Use Land Cover Scenarios}

N. Voisin, J. Richey, M. Wigmosta, T. Tesfa, and J. Whiting 


\section{Contents}

Appendix I . Watershed Hydrology under Climate Change and Land Use Land Cover Scenarios............. 1

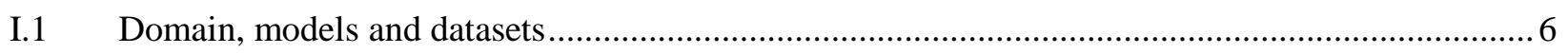

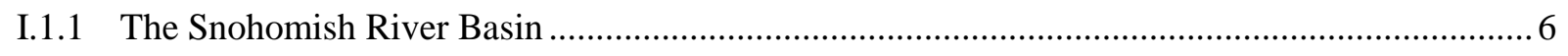

I.1.2 The Hydrology Model ................................................................................................

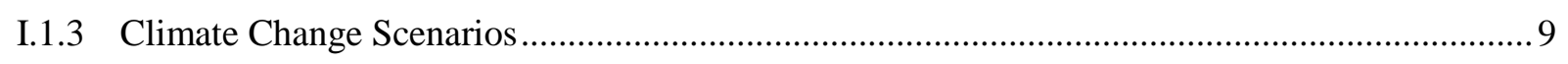

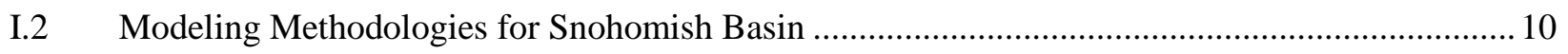

I.2.1 The 2002 and 2050 land use maps.................................................................................... 11

I.3 Effect of land use and climate changes over the Snohomish River Basin .................................. 14

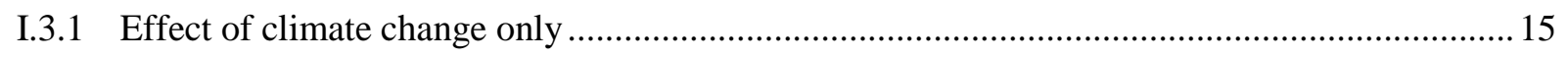

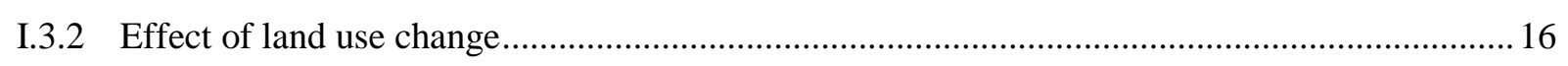

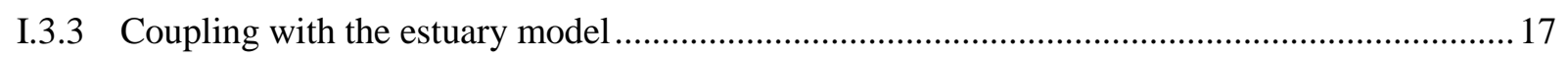

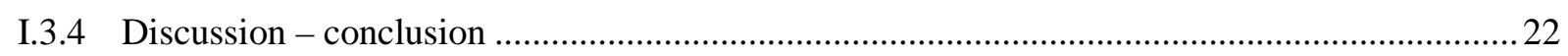

I.4 Effect of changes in land use and climate over the upper Snohomish basins, with application to

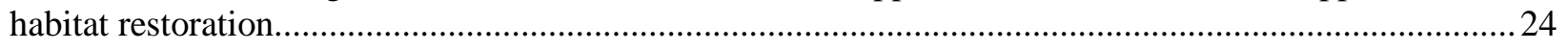

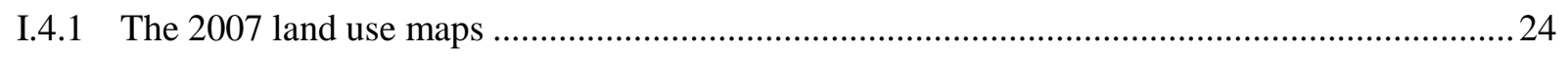

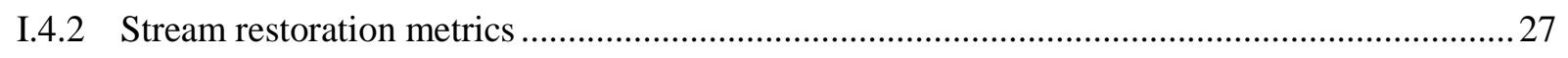

I.4.3 Model set up for examining subbasins of interest ............................................................. 29

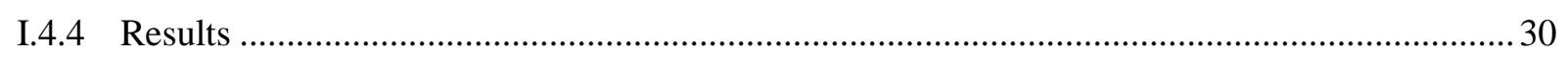

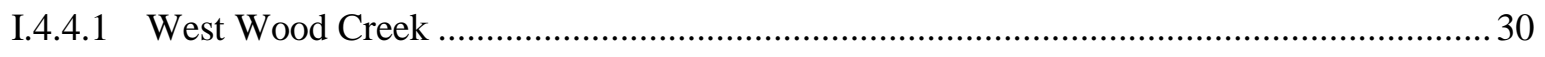

I.4.4.2 South Fork of the Skykomish: .................................................................................. 34

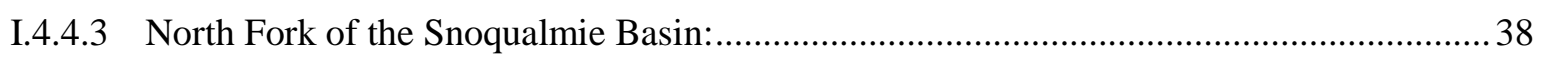

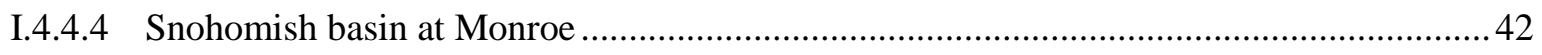

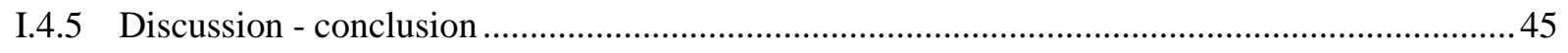

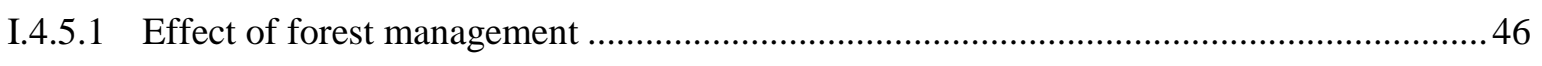

I.4.5.2 Forest management and climate change ................................................................. 47

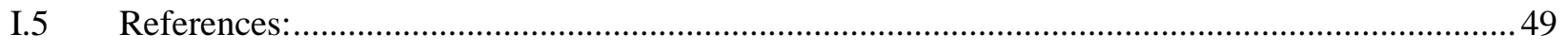

I.6 Supplemental information on subbasin responses ............................................................. 52 


\section{Figures}

Figure I - 1. Elevation maps of the Snohomish Basin upstream of Monroe (station \#1). Basin USGS gauges are located for reference. Red dots are the specified locations of interest to analyze the effects of land use and climate changes over streamflow for stream restoration: Monroe, 1; West Woods Creek, 2; South Fork Skykomish, 3; North Fork Snoqualmie, 4.

Figure I - 2. Mean monthly natural flow simulated by DHSVM and corresponding observed USGS regulated flow from stream gages.

Figure I - 3: Land cover layers for the Snohomish Basin for the historical 2002 time period (top panel) and future vegetation coverage represented by projections to 2050 (bottom panel). Changes between 2002 and 2050 are noted as the increase in urbanized areas, shown predominantly in red.

Figure I - 4: Long term mean monthly simulated flow at Monroe for the 6 land and climate scenarios......................15

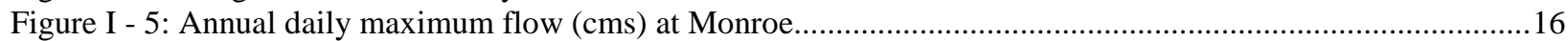

Figure I - 6: Flow statistics for Monroe in August: Climate change dominates the change in interannual variability and maximum August flow. Climate change tends to decrease the interannual monthly variability while land use change tends to increase it.

Figure I - 7: Flow statistics for Monroe in December: Climate change and land use change effects accumulate and results in an increased average flow, minimum, maximum and interannal variability in the December flow. Monthly December flow is most sensitive to climate change than to land use change.

Figure I - 8: Effect of updating the land cover over the mean monthly hydrograph over the Snohomish River (Monroe), and subbasins of interest; South Fork of the Skykomish, North Fork of Snoqualmie and West Woods Creek. Close ups of individual basins can be found in the final section of this appendix. .....................26

Figure I - 9: Experimental Design to isolate effects of climate and land use changes..............................................30

Figure I - 10: Monthly flow hydrograph at West Woods Creek under current managed forest (LC2007) and hypothetical unmanaged forest (LC2007M) under current (historical) and future (A1B, B1) climate conditions.

Figure I - 11: Annual daily flood cumulative density function for West Woods Creek for current managed forest (LC2007) and hypothetical unmanaged forest (LC2007M) under current (historical) and future (A1B, B1) climate conditions.

Figure I - 12: Monthly flow hydrograph for the South Fork of the Skykomish River under current managed forest (LC2007) and hypothetical unmanaged forest (LC2007M) under current (historical) and future (A1B, B1) climate conditions.

Figure I - 13: Annual daily flood cumulative density function for the South Fork of the Skykomish for current managed forest (LC2007) and hypothetical unmanaged forest (LC2007M) under current (historical) and future (A1B, B1) climate conditions.

Figure I - 14: Monthly flow hydrograph for the North Fork of the Snoqualmie River under current managed forest (LC2007) and hypothetical unmanaged forest (LC2007M) under current (historical) and future (A1B, B1) climate conditions.

Figure I - 15: Annual daily flood cumulative density function for the North Fork of the Snoqualmie River for current managed forest (LC2007) and hypothetical unmanaged forest (LC2007M) under current (historical) and future (A1B, B1) climate conditions.

Figure I - 16: Monthly flow hydrograph at Monroe under current managed forest (LC2007) and hypothetical unmanaged forest (LC2007M) under current (historical) and future (A1B, B1) climate conditions.

Figure I - 17: Annual daily flood cumulative density function at Monroe for current managed forest (LC2007) and hypothetical unmanaged forest (LC2007M) under current (historical) and future (A1B, B1) climate conditions.

Figure I - 18: summary of the effect of forest management practices and predicted climate change on mean monthly

flow over the 4 basins of interest. ...........................................................................................................

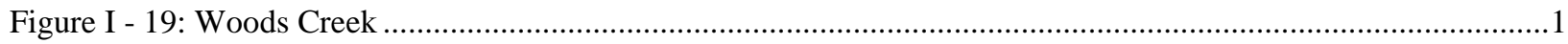

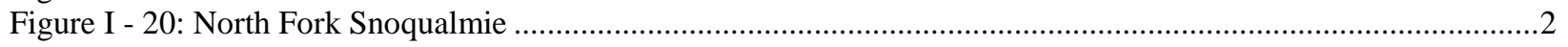

Figure I - 21: South Fork Skykomish ………………..................................................................................... 


\section{Tables}

Table I - 1. Statistics for DHSVM monthly streamflow (cms) simulation at Monroe.

Table I - 2: Elsner et al. (2010) precipitation scaling deltas and temperature deltas for SRES B1 and A1B scenarios

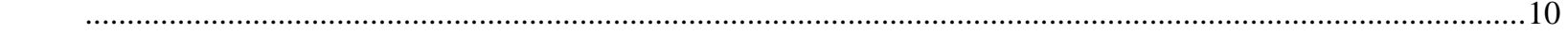

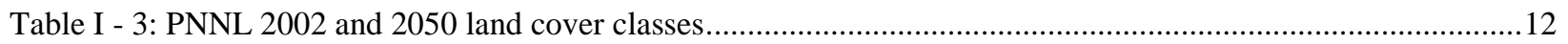

Table I - 4: scenario to assess impact of changes in land use and climate ..............................................................14

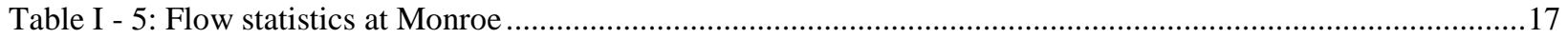

Table I - 6: DHSVM-FVCOM Model Runs and Analysis Matrix........................................................................18

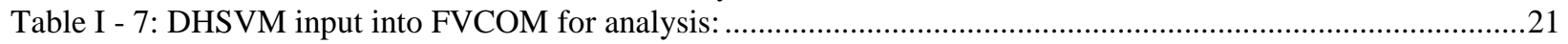

Table I - 8: summary of land use change and climate change effects on flow at Monroe .........................................23

Table I - 9: Updated 2007 land cover vegetation class and correspondence with DHSVM classes ...........................25

Table I - 10: Hydrologic indices for comparing flow regimes. These indices and their codes are commonly used in existing analyses tools, including the Hydrologic Index Tool (USGS) ….......................................................28

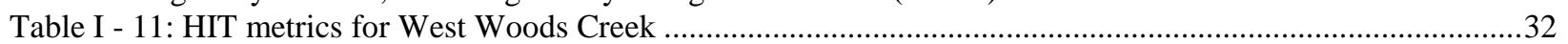

Table I - 12: HIT metrics for the South Fork of the Skykomish........................................................................36

Table I - 13: HIT metrics for the North Fork of the Snoqualmie River ................................................................

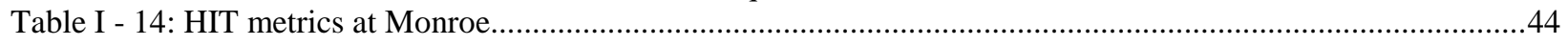

Table I - 15: Summary of the effects of forest management practices on specific flow characteristics over a series of hydro-climatological conditions ....................................................................................................................4

Table I - 16: Summary of dominant drivers of change for specific flow characteristics for different hydro-

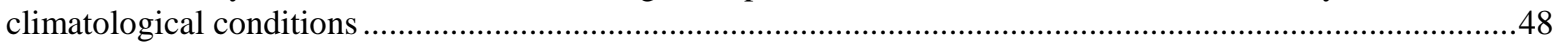

Table I - 17. Skykomish (USGS gage 12133000) - LC2002 vs. LC2050 …….........................................................52

Table I - 18. West Woods Creek - LC2002 vs. LC2050 ……..............................................................................53

Table I - 19. North Fork Snoqualmie - LC2002 vs. LC2050 .................................................................................54 


\section{Appendix I. Introduction}

Distributed hydrology models have been used to assess the combined impact of land use change and climate change on freshwater systems (Cuo et al. 2011, Mishra et al. 2010). There have been few attempts to transfer the influence of climate change and land use change downstream to estuarine models from watershed models because there is a mismatch in dimensional, temporal and spatial resolutions used by hydrology models and estuary models. Fine scale distributed hydrological models like the Distributed Hydrology-Soil-Vegetation Model (DHSVM, Wigmosta et al. 1994) typically solves the energy and water balance at the scale of land grid cells of $150 \mathrm{~m}$ by $150 \mathrm{~m}$ at a 3 hourly time step, using a 1-D routing Muskingum scheme algorithm with sub time steps.

The challenges for providing output from watershed models to estuarine models occur because most are either 2-D (ADvanced CIRCulation, ADCIRC, Westerink et al. 1992) or 3-D (FVCOM) hydrodynamic coastal ocean models, rather than 1D. The estuarine model used for this project is FVCOM that runs at a 5 seconds time steps and on an unstructured grid with a maximum of several meters.

The objectives of this study are to: 1) Develop an approach to couple a watershed hydrology model with an estuarine model that reconciles the temporal, spatial and dimensional structures of the models to communicate the seasonal and shorter time scale effects of climate and land use changes on fresh water inflow into the estuary model (or "make the uplands model talk to the estuary model"); and 2) Evaluate the effects of recent land use changes, in particular forestry practices, with respect to climate change effects in the upstream part of a snow-rain transition basin for application to stream restoration.

The focus of this study is on the Snohomish Basin which is a snow-rain transition basin located on the western slopes of the Cascade Mountains range in Washington State, USA. The Snohomish Basin discharges into Puget Sound, a deep fjord-type estuary. The Puget Sound basin has been the object of extended studies on the impact of land use and climate change on freshwater (Cuo et al. 2009, Cuo et al., 2011, Elsner et al. 2010). We leverage from those analyses and modeling approaches, setting up differing initial conditions and using different land cover data to address each of the two objectives.

In the next section we provide details about the Snohomish basin and stream gages relevant to this study, we introduce the watershed model DHSVM used in the study, and describe the climate change and land use scenarios used to evaluate and compare impacts. Section 3 presents the modeling framework used to couple the hydrology and estuary models to address the first objective. Section 4 evaluates the effect of recent land use change in upper Snohomish River basins and identifies drivers of change in specific flow characteristics. 


\section{I.1 Domain, models and datasets}

\section{I.1.1 The Snohomish River Basin}

The Snohomish River Basin is the second largest watershed in the Puget Sound Basin (after the Skagit River Basin), draining 4,807 km² (Figure I - 1). The Skykomish and the Snoqualmie rivers flow into the Snohomish River upstream of Monroe, WA, which is the upper boundary to the estuary model. Downstream of Monroe, river, slough, flats and estuary are influenced by the tides, as well as inflow from the river. The Snohomish Basin is one of the fastest developing watersheds in the region and maintains an active forestry industry. The basin is home to Everett, the fourth largest city in Washington State, expanding suburbs and smaller municipalities, extensive agricultural lands, and significant forests and wetlands.

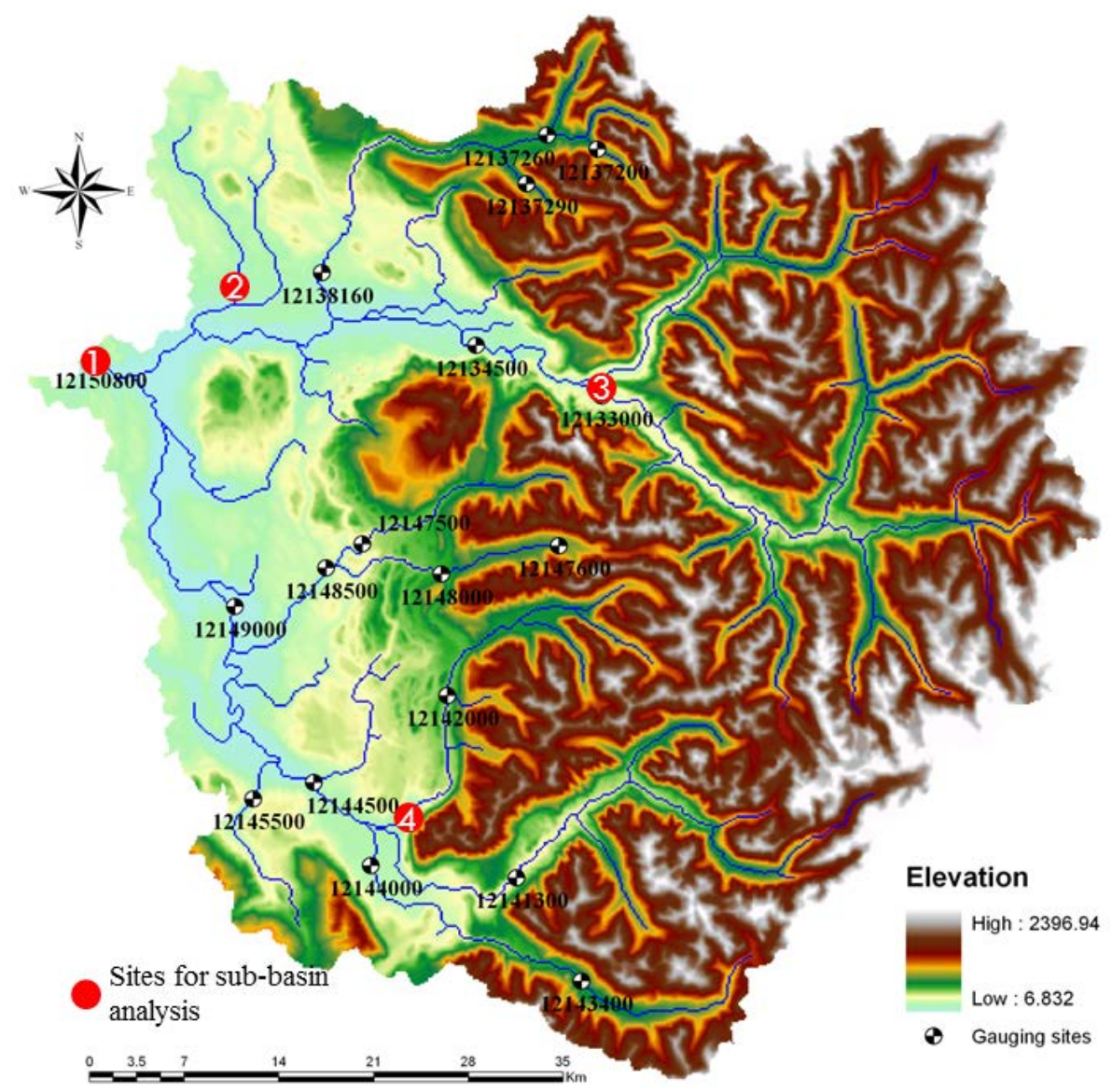

Figure I - 1. Elevation maps of the Snohomish Basin upstream of Monroe (station \#1). Basin USGS gauges are located for reference. Red dots are the specified locations of interest to analyze the effects of land use and climate changes over streamflow for stream restoration: Monroe, 1; West Woods Creek, 2; South Fork Skykomish, 3; North Fork Snoqualmie, 4. 
Monroe is the point of transfer of information from the hydrology model into the estuary model. Analysis of climate change and land use impacts is focused on four subbasins with forestry active in the last century: West Woods Creek, South Fork of Skykomish, North Fork of Snoqualmie, and also at the basin scale at Monroe.

\section{I.1.2 The Hydrology Model}

The distributed hydrology-soil-vegetation model (DHSVM; Wigmosta et al., 1994, 2002) was selected to represent hydrology processes in the freshwater portion of the basin. DHSVM was originally designed for mountainous forested watersheds and is primarily a saturation excess model. Recently, however, Cuo et al. (2008) incorporated parameterizations that allow the model to represent some aspects of runoff generation in urban basins, including impervious surfaces, and runoff detention and release in artificial conveyance systems, such as pipes and ponds.

DHSVM represents the physical processes that control runoff generation, including the land surface energy balance, unsaturated soil moisture movement, saturation overland flow, snow melt and accumulation, and water table recharge and discharge. Using a digital elevation model (DEM) as a base map, DHSVM explicitly accounts for soil and vegetation types, and stream channel network and morphology. Land class attributes used by DHSVM include soil surface properties such as impervious surface area, infiltration capacity, vegetation morphology parameters such as vegetation height, canopy coverage fraction, trunk size, and vegetation phenology characteristics such as minimum stomatal resistance, leaf area index (LAI), and albedo. These parameters are used for calculating surface water infiltration, the wind profile through the vegetation canopy, radiation balance through the canopy, and water vapor transport.

DHSVM has been widely used in the Pacific Northwest, mostly with emphasis on the effects of forest harvest on runoff (Storck et al., 1998; Bowling et al., 2000; Schnorbus et al., 2004). Cuo et al. (2009) implemented DHSVM throughout the Puget Sound basin and evaluated the relative effects of land cover change (1883 vs. 2002) and observed climate change from 1915 to 2006. The same model parameters as in Cuo et al. (2009) were used to study the effects of future climate and land cover change on the hydrology of the Puget Sound basins in Cuo et al. (2011) , and specifically over the Sultan Basin in Vano et al. (2010) in order to assess the effect of climate change on water resources. The model is set up with 150 meter by 150 meter grid cell sizes and runs with a 3-hourly time step. DHSVM requires hourly meteorological forcing at more than one pseudo or actual stations in or adjacent to the basin, that includes air temperature, precipitation, relative humidity, incoming solar and longwave radiation, and wind speed. The historical 1915-2005 hourly meteorological dataset was derived by Elsner et al. (2010): a 19152005 daily dataset at $1 / 16^{\text {th }}$ degree comprised of precipitation, maximum and minimum temperatures and wind speed was derived as an extension and downscaled version of Hamlet and Lettenmaier (2005), which also derived from the $1 / 8^{\text {th }}$ degree $1950-2000$ Maurer et al. (2002) dataset with additional checks on the stations used. This daily meteorological dataset was fed 
into a weather data disaggregator embedded in the Variable Infiltration Capacity hydrology model (VIC, Liang et al. 1994) which includes the Thornton and Running (1999), Kimball et al. (1999) and Bras (1990) algorithms, which are implemented in VIC and are used here to derive in hourly incoming solar and longwave radiations and vapor pressure required by DHSVM.

DHSVM outputs 3-hourly flow discharge at specified locations, as well as basin average water balance and energy budget components. The output of interest for our analysis is daily and monthly flow discharge at the 4 locations of interest presented above. Figure I - 2 and Table I - 1 presents the Cuo et al. (2008, 2010 and 2011) DHSVM performance at Monroe.

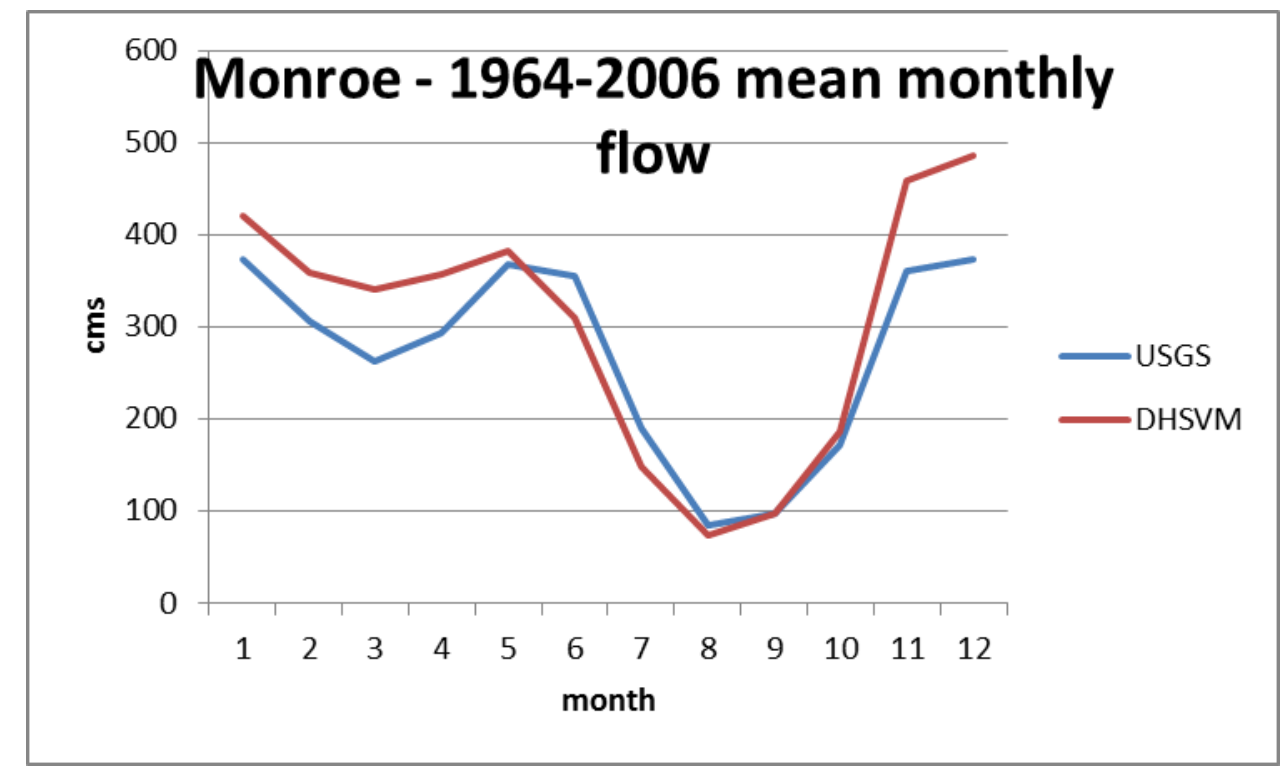

Figure I - 2. Mean monthly natural flow simulated by DHSVM and corresponding observed USGS regulated flow from stream gages.

Table I - 1. Statistics for DHSVM monthly streamflow (cms) simulation at Monroe

\begin{tabular}{llll}
\hline 1964-2006 & & & \\
& USGS & DHSVM & sim/obs \\
\hline Mean & 270 & 302 & 1.12 \\
Standard deviation & 156 & 182 & 1.17 \\
RMSE & & 93 & \\
MAE & & 67 & \\
Correlation & & 0.88 & \\
\hline
\end{tabular}




\section{I.1.3 Climate Change Scenarios}

Global Circulation Models (GCM) simulation results for the twenty-first century produced for the Inter-governmental Panel for Climate Change (IPCC) have been archived for 24 models by the Program for Climate Model Diagnosis and Intercomparison (PCMDI). IPCC has defined a standard set of global greenhouse gas emissions scenarios as described in the IPCC Special Report on Emissions Scenarios (SRES) 2001 report (SRES, 2001). The SRES climate change emission scenarios differ to a certain extent from the newly developed Representative Concentration Pathways (RCPs) for the upcoming 2014 Intergovernmental Program on Climate Change Report. Similarly, the Global Circulation Models to be forced with the emission scenarios and used in the previous reports have also evolved. The GCM's downscaled simulations forced with RCPs emission scenarios were not available when the project started and it could be considered for future projects.

As a practical matter, SRES emission scenarios A1B, B1, and A2 are the most commonly used, and, among these, the largest number of archived GCM runs archived are for A1B. Both A1B and A2 scenarios reflect a somewhat pessimistic view of the likelihood of stabilization (and eventual reduction) of global greenhouse gas emissions over the twenty-first century, whereas B1 reflects stabilization by about mid-century, and reductions thereafter. Consistent with higher greenhouse gas concentrations, the A2 and A1B scenarios generally indicate somewhat larger increases in temperature than B1, especially after the 2020s. However, differences among the various SRES scenarios are modest until about the mid-twenty-first century, when they begin to diverge. We follow Elsner et al. (2010) and used A1B and B1 scenarios in order to provide a pessimistic and middle of the range / optimistic scenarios, with the understanding that those scenarios do not differ significantly until mid-century. The Global Circulation models (GCMs) simulations (2010-2099) are archived at monthly time steps, and a 2 or 2.5 degree spatial resolution. Those simulations need downscaling in order to force a hydrology model at a 3hourly time step and 150 meter spatial resolution.

Elsner et al. (2010) used a delta method approach for spatially and temporally downscaling the climate change scenario to the spatial and temporal scale of the hydrology model. The delta method approach allows the combination of climate characteristics from multiple Global Climate Models (GCMs) over different climate periods. For ease of description, climate from the 2030s to 2050s will be referred to as the 2040s, and climate from 2070 to 2090 will be referred to as the 2080s. The historical period (1915-2005) has first been detrended and then has been adjusted for future period (2040s and 2080s) climate characteristics. This approach is ideal for analyzing the effect of climate change on water resources management as it provides a long time series to describe a future period and allows increased confidence for statistics used for planning (for example, low recurrence events).

Cuo et al. (2011) opted for using transient runs for assessing the impact of climate change on the hydrology of the Puget Sound Basins. A bias correction and statistical disaggregation (BCSD) approach is then applied for one climate change scenario but for multiple GCMs. 
Averaged over a similar period, hydrological predictions derived from a delta method and bias corrected and downscaled transient runs are similar. Transient runs are much more computationally intensive - they offer quantification of uncertainties with respect to multiple GCMs and offer flexibility in defining the timing for system performance or failure. Note that in Cuo et al. (2011) the analysis of the effect of land use change and land cover change were analyzed over specific climate periods for clarity.

Keeping in mind that the estuary model is more computationally intensive than the hydrology model, and that hydrological analyses upstream of Monroe should be linked to defining flow characteristics (low return frequency low and high flow, etc.) the delta method approach for our climate change analysis was deemed most appropriate and we focus on the 2040s climate. The deltas obtained from Elsner et al. (2010) applied to the historical meteorological dataset are presented in Table I - 2.

Table I - 2: Elsner et al. (2010) precipitation scaling deltas and temperature deltas for SRES B1 and A1B scenarios

\begin{tabular}{|c|c|c|c|c|c|c|c|c|c|c|c|c|}
\hline & Jan & Feb & Mar & Apr & May & Jun & Jul & Aug & Sep & Oct & Nov & Dec \\
\hline \multicolumn{13}{|c|}{ SRES B1 Temperature (C) } \\
\hline $2020 s$ & 1.10 & 1.08 & 1.11 & 1.03 & 1.01 & 1.06 & 1.34 & 1.30 & 1.21 & 0.99 & 0.79 & 1.01 \\
\hline $2040 s$ & 1.49 & 1.41 & 1.46 & 1.45 & 1.37 & 1.44 & 2.05 & 2.05 & 1.90 & 1.37 & 1.17 & 1.65 \\
\hline $2080 s$ & 2.53 & 2.39 & 2.27 & 2.23 & 2.04 & 2.49 & 3.07 & 3.22 & 2.91 & 2.14 & 2.12 & 2.53 \\
\hline \multicolumn{13}{|c|}{ SRES B1 Precipitation (\%) } \\
\hline 2020s & 0.89 & -0.61 & 3.40 & 3.35 & 0.08 & -1.36 & -0.94 & -3.48 & -6.32 & 6.66 & 6.07 & 3.81 \\
\hline 2040s & -1.21 & 0.34 & 5.58 & 3.39 & 1.98 & -1.14 & -4.91 & -8.69 & -6.49 & 5.19 & 7.04 & 6.61 \\
\hline 2080s & 5.19 & 3.22 & 3.06 & 6.11 & 2.91 & -6.69 & -10.52 & -15.58 & -4.72 & 6.90 & 8.81 & 9.35 \\
\hline \multicolumn{13}{|c|}{ SRES A1B Temperature (C) } \\
\hline $2020 s$ & 1.22 & 0.99 & 1.11 & 0.99 & 1.01 & 1.28 & 1.59 & 1.60 & 1.37 & 1.00 & 0.83 & 1.17 \\
\hline $2040 s$ & 1.99 & 1.75 & 1.90 & 1.74 & 1.68 & 2.13 & 2.79 & 2.72 & 2.50 & 1.86 & 1.56 & 1.94 \\
\hline 2080s & 3.59 & 3.25 & 3.22 & 2.87 & 2.69 & 3.66 & 4.59 & 4.73 & 4.20 & 3.15 & 2.85 & 3.40 \\
\hline \multicolumn{13}{|c|}{ SRES A1B Precipitation (\%) } \\
\hline 2020s & 0.01 & 0.16 & 2.04 & 1.30 & -1.24 & -5.87 & -9.89 & -9.78 & -8.53 & 2.41 & 5.66 & 2.93 \\
\hline $2040 s$ & 4.38 & 0.77 & 6.28 & 5.75 & -0.56 & -9.97 & -15.45 & -12.17 & -12.51 & 6.94 & 8.11 & 5.53 \\
\hline $2080 \mathrm{~s}$ & 6.23 & 6.95 & 10.50 & 8.83 & -0.09 & -11.06 & -18.08 & -22.04 & -8.23 & 12.71 & 11.21 & 10.91 \\
\hline
\end{tabular}

\section{I.2 Modeling Methodologies for Snohomish Basin}

A standard approach to evaluating the effects of land use change and climate change on a river basin is hydrologic modeling. We build off from Elsner et al. (2010) historical and future periods meteorological datasets (B1 and emission scenarios) to force the distributed hydrology model DHSVM with 2002 and projected 2050 land cover maps; these maps are derived from Cuo et al. (2011) set up for similar analysis for the entire Puget Sound. In order to address how the projected changes in land use and climate over the Snohomish Basin will affect the estuary model, we develop an approach to couple both models that reconcile the difference in spatial and 
time scales between the surface hydrology and the hydrodynamic models and computational requirements. The DHSVM hydrology model presented above is used to represent the Snohomish Basin hydrology under future and current conditions, i.e. land use and climate. Historical and future climate have been presented in the previous sections. Here we present the current and future projected land use scenarios, next the effect of land use and climate change on the Snohomish River Basin discharge, and finally we present the coupling approach and the information to be transferred to the estuary model.

\section{I.2.1 The 2002 and 2050 land use maps}

Central Puget Sound land cover data were obtained from the Urban Ecology Research Laboratory (Puget Sound Regional Synthesis Model (PRISM), University of Washington, http://urbaneco.washington.edu/wp/resources/data/). As part of the project, we ran the model with both the 2002 and the projected 2050 land use data (Figure I - 3) as the present and future situations (i.e., as did Cuo et al. (2011)). An initial 2027 land use projection was derived for increase in population and extension of the cities by Alberti et al. (2004). This 2027 land cover was extended to 2050 as described in Annex A of Cuo et al. (2011). Land cover data are derived from USGS Landsat (Thematic Mapper and Enhanced Thematic Mapper) images of Central Puget Sound. Landsat data were registered, intercalibrated, and corrected for atmosphere and topography to ensure accuracy of land cover change assessment. In those two land covers, forests are identical in maturity. Table I - 3 describes the original vegetation classes associated with the 2002 land cover. Those land cover classes are used in order to be consistent with previous literature in the region (Cuo et al. 2011, Elsner et al. 2010, Vano et al. 2010). 
Table I - 3: PNNL 2002 and 2050 land cover classes

\begin{tabular}{|c|c|c|}
\hline PNNL class description & $\begin{array}{l}\text { PNNL } \\
\text { class }\end{array}$ & Description \\
\hline dense urban & 1 & $>=75 \%$ urbanized \\
\hline light medium urban & 2 & $<75 \%$ urbanized \\
\hline Bareground & 3 & No tree, no vegetation on surface \\
\hline dry ground & 4 & $\begin{array}{l}\text { No tree, short vegetation, seasonally low and high coverage from } \\
\text { leaves etc. }\end{array}$ \\
\hline$\sim$ native grass & 5 & $\begin{array}{l}20 \text { m high trees and bushes - open forest ( } 50 \% \text { coverage) - high } \\
\text { coverage from vegetation }\end{array}$ \\
\hline grass crop shrub & 6 & $\begin{array}{l}\text { No tree, medium }(1 \mathrm{~m}) \text { vegetation on surface, high coverage from } \\
\text { leaves }\end{array}$ \\
\hline mixed/deciduous forest & 7 & Mixed forest, $25 \mathrm{~m}$ high trees, $85 \%$ coverage, and short vegetation \\
\hline conifer forest & 8 & $\begin{array}{l}43 \text { m high trees, 90\% coverage, and short vegetation, very high } \\
\text { shading }\end{array}$ \\
\hline Regrowth & 9 & $\begin{array}{l}\text { No tree, medium }(1 \mathrm{~m}) \text { surface vegetation, limited coverage from } \\
\text { vegetation }\end{array}$ \\
\hline clear cuts & 10 & No tree, short vegetation (.5m), limited coverage from leaves (.5) \\
\hline Rocks & 11 & \\
\hline Wetland & 12 & $\begin{array}{l}\text { No tree, short vegetation }(.5 \mathrm{~m}) \text {, limited coverage from leaves }(.5) \text {. } \\
\text { Different Soil. }\end{array}$ \\
\hline Shoreline & 13 & $\begin{array}{l}\text { No tree, short vegetation }(.5 \mathrm{~m}) \text {, limited coverage from leaves }(.5) \text {. } \\
\text { Different Soil. }\end{array}$ \\
\hline Water & 14 & Open water including seasonal and permanent waterbodies \\
\hline
\end{tabular}




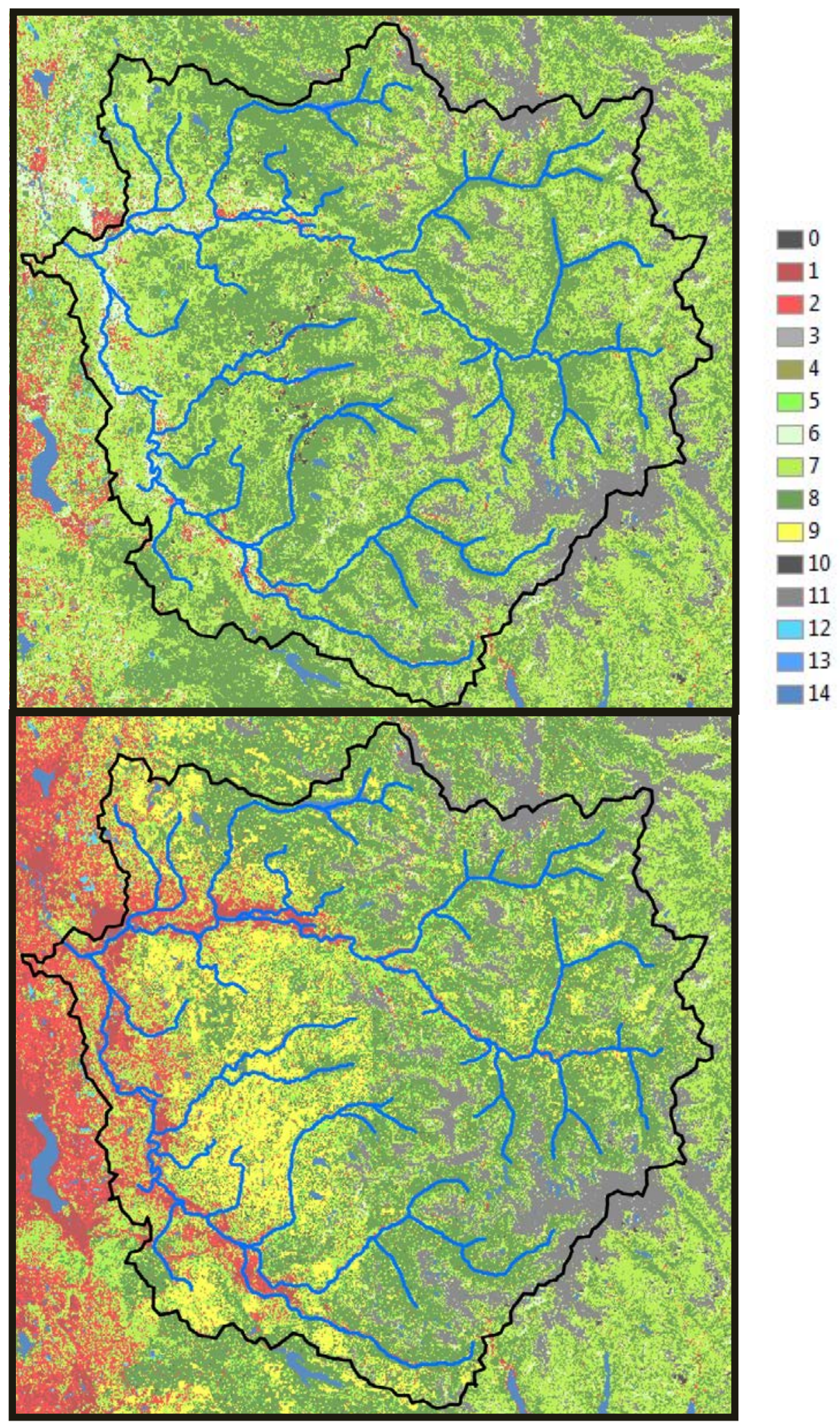

Figure I - 3: Land cover layers for the Snohomish Basin for the historical 2002 time period (top panel) and future vegetation coverage represented by projections to 2050 (bottom panel). Changes between 2002 and 2050 are noted as the increase in urbanized areas, shown predominantly in red. 


\section{I.3 Effect of land use and climate changes over the Snohomish River Basin}

The unstructured grid Finite Volume Coastal Ocean Model (FVCOM) is an open source code ocean community model that has previously been applied to the Puget Sound Basin (Khangaonkar and Yang 2011). There are three open boundaries - Possession Sound, Saratoga Passage and Port Susan Bay. The upstream river boundary is specified at USGS gage near city of Monroe. FVCOM forcing includes tide at open boundaries (XTide prediction - available); meteorological input (wind, heat flux - available at nearby met station or model prediction (Weather Research and Forecasting model WRF, or North American Regional Reanalysis NARR)); river inflow (and temperature) from upstream USGS gage or model outputs.

The estuary model FVCOM and the hydrology model are coupled in a one-way mode, with Monroe as the point of transfer of information, i.e. flow information. The evaluation of climate and land use change for this coupling focuses on Monroe only (USGS gage 12150800). Table I 4 presents the DHSVM simulations, or scenarios, which support the impact assessment climate and land use changes at the basin scale (Monroe).

Table I - 4: scenario to assess impact of changes in land use and climate

\begin{tabular}{|l|l|l|}
\hline & Land Use Cover 2002 & Land Use Cover 2050 \\
\hline Historical (2000s) & Hist_lc2002( baseline) & Hist_lc2050 \\
\hline $\begin{array}{l}\text { Future period, 2040s horizon, A1B } \\
\text { emission scenario }\end{array}$ & 2040s_lc2002_A1B & 2040s_lc2050_A1B \\
\hline $\begin{array}{l}\text { Future period, 2040s horizon, B1 } \\
\text { emission scenario }\end{array}$ & 2040s_lc2002_B1 & 2040s_lc2050_B1 \\
\hline
\end{tabular}

The historical simulated flow at Monroe with the 2002 land cover is used as the baseline. Evaluating flow simulations at Monroe from 2040s_lc_2002_A1B (2040s_lc_2002_B1) with hist_lc_2002 DHSVM simulations (constant land cover) isolates the effect of change in climate on the flow. The same evaluation is performed using 2050 land cover. Similarly, evaluating flow simulations at Monroe from hist_lc2050 with hist_lc2002 and during future period with DHSVM simulations (constant climate) isolates the effect of change in land use on the flow.

We compare the historical simulation with the historical land cover (hist_2002), with the future periods flow simulations with future land cover (2040s_lc2050_A1b and 2040s_lc2050_B1), in order to evaluate the combined effects of changes in land use/land cover. 


\section{I.3.1 Effect of climate change only}

We evaluate the changes in flow for historical and future simulations using a fixed land cover, i.e. 2002 only or 2050 only). The seasonality of the mean monthly hydrograph is analyzed, followed by an analysis of the mean annual daily flow.

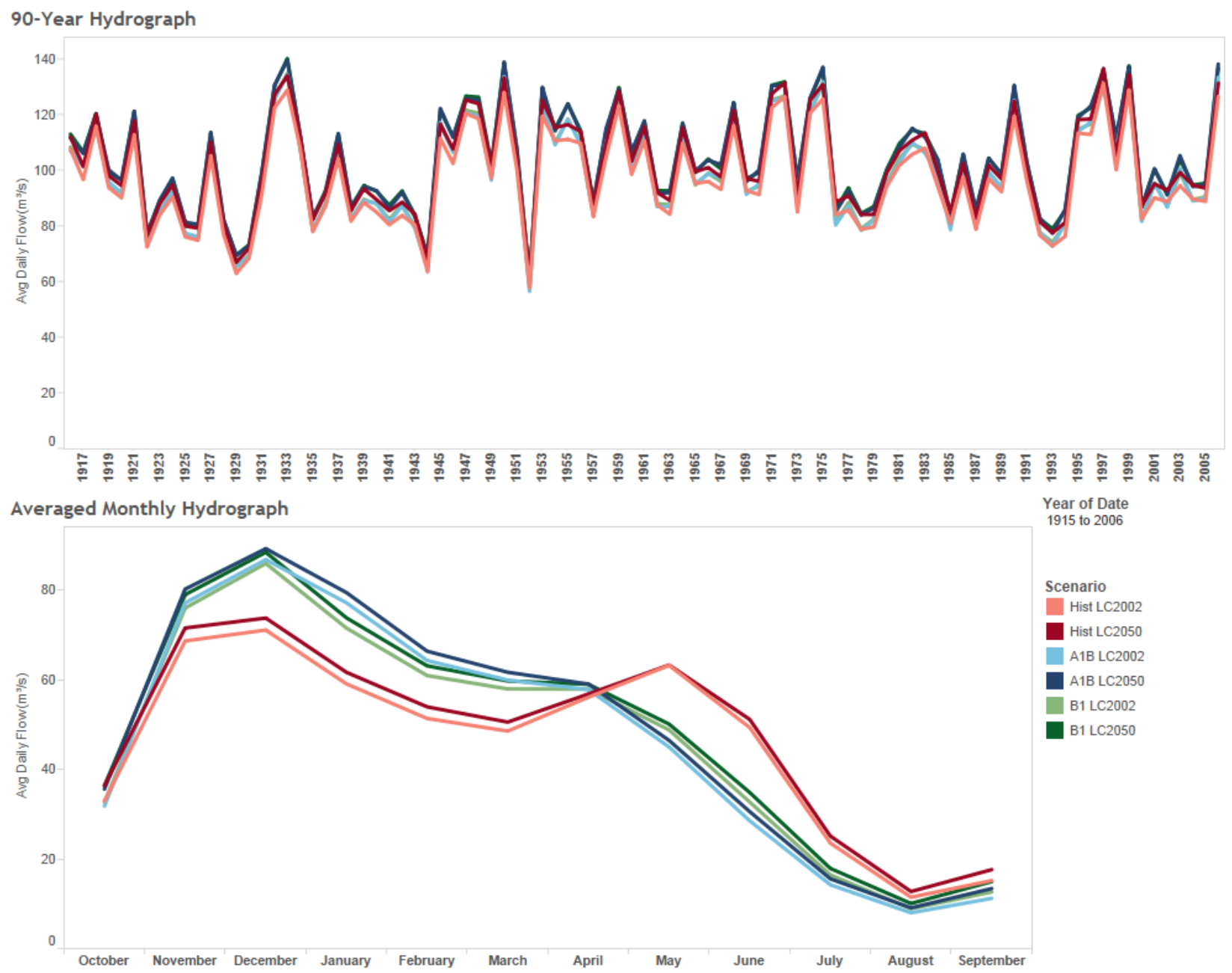

Figure I - 4: Long term mean monthly simulated flow at Monroe for the 6 land and climate scenarios

The Snohomish is a rain-snow transition basin as shown by the two streamflow peaks in the Fall and Spring. The most pronounced effects of climate change effects are on the shift of snow to rain precipitation, therefore increasing the fall monthly flows and decreasing the snowmelt peak, which correspond to the Western Cascade predicted change (Elsner et al. 2010, Cuo et al. 2011, Vano et al. 2010a). 
Table I - 5 presents the metrics evaluating the change in flow at annual and daily time scales due to the changes in climate. The change in precipitation is relatively uncertain the annual time scale, as shown by the precipitation deltas used for adjusting the precipitation forcing (Table I - 2). However with an increase in temperature, less precipitation falls as snow and the streamflow peak in the fall is predicted to increase while the snowmelt peak in the spring is expected to decrease. This also results in summer flows that are decreased by 14 to $20 \%$ depending on the climate scenario and land use layer. The uncertainty between climate change scenarios is small in comparison with the projected shift from rain-snow transition basin to rain dominated basin from historical to future periods. The mean annual flow is also affected with a predicted decrease of about $2 \%$ due to the change in evapotranspiration.

Extreme precipitation events and annual daily flood occur in the fall and will remain so under future conditions (Table I - 5). The annual daily flood is expected to increase (Figure I - 5) and the 7-day flood is also expected to increase between 14 and $17 \%$. The 7-day minimum flow is expected to decrease by 16 to $24 \%$.

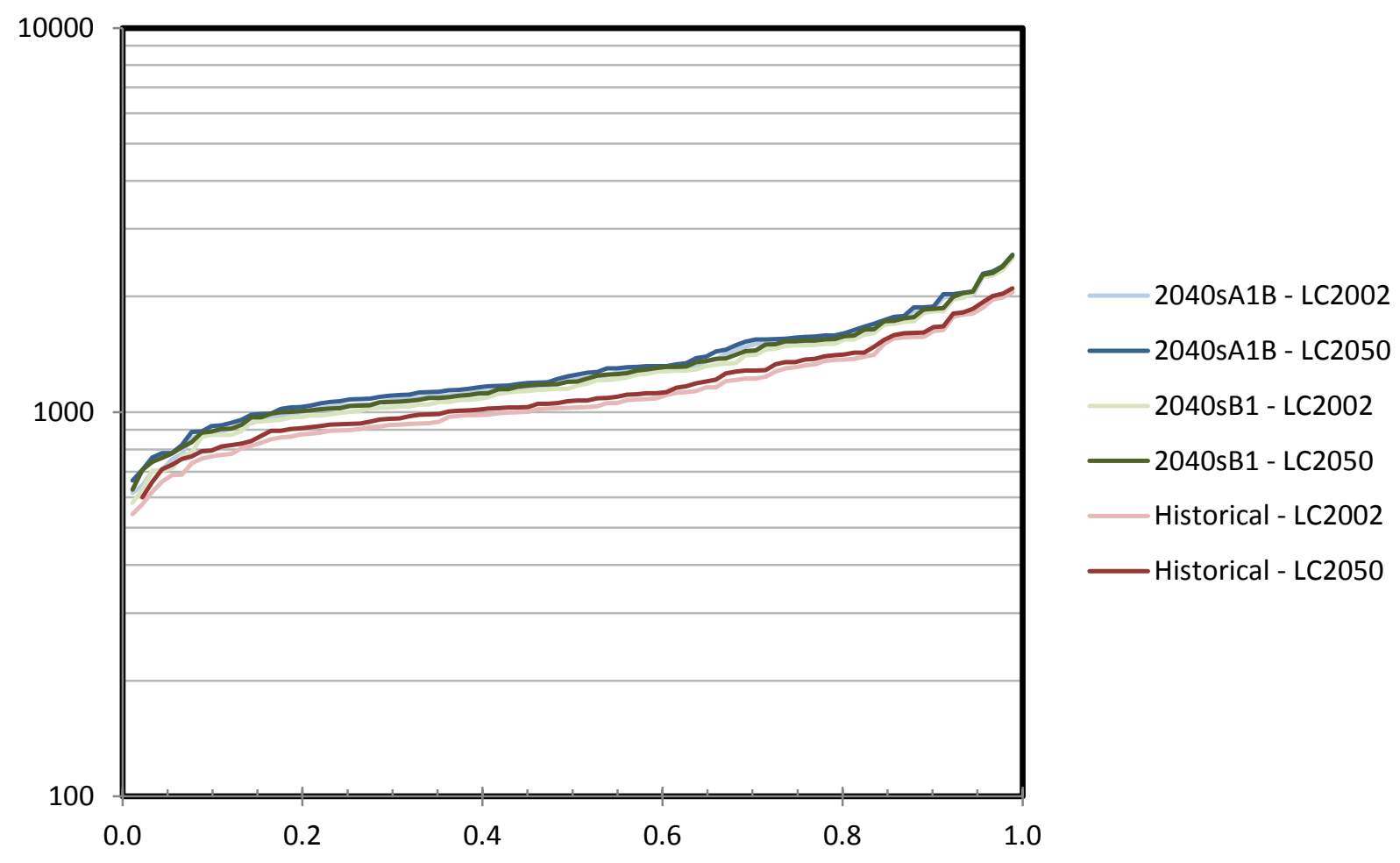

Figure I - 5: Annual daily maximum flow (cms) at Monroe

\section{I.3.2 Effect of land use change}

The effect of land use change is evaluated by comparing flow simulation over the same time period (either present or future) with different land covers. Based on the long term mean monthly hydrograph (Figure I - 4), land use change (i.e. mostly urbanization and turning forest into 
shrubs) will result in a higher snowmelt peak and higher summer flow (15\%). Table I - 5 presents metrics for quantifying the changes in annual and daily flow due to land use change. The mean annual flow is expected to increase (6\%) due to lower evapotranspiration losses overall. At the Snohomish River basin scale, the 7-day maximum should increase by 5\% but changes in extreme annual daily precipitation are mostly driven by climate change rather than by land use change (Figure I - 5).

Table I - 5: Flow statistics at Monroe

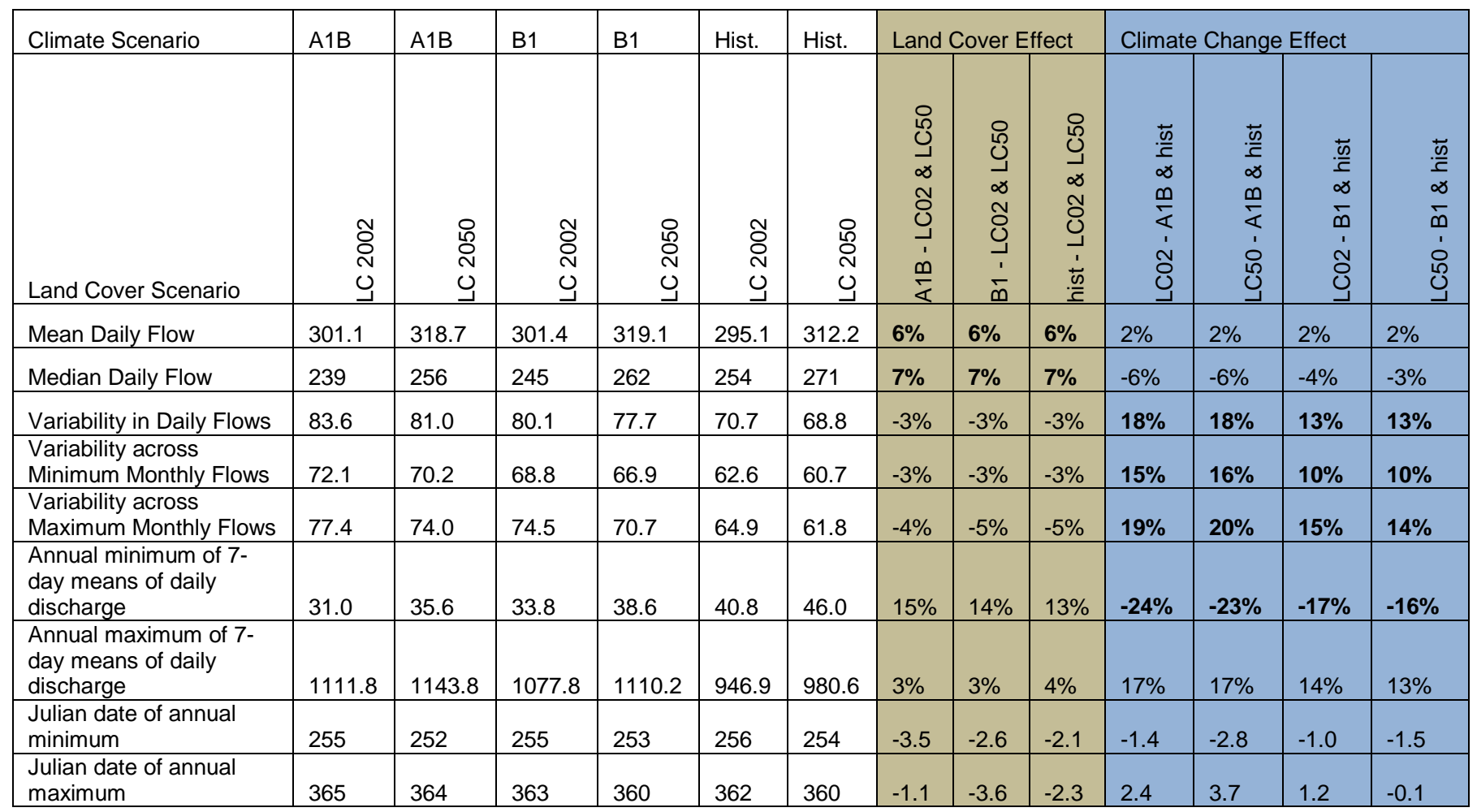

\section{I.3.3 Coupling with the estuary model}

The hydrology model DHSVM and the estuary model FVCOM are linked in a one-way coupling mode; there is no feedback from FVCOM simulations into DHSVM simulations. Both models are run in stand-alone mode. In order to explore the effect of climate change and land use change over the estuary model, technical aspects need to be taken into consideration, in particular the computation time of FVCOM.

FVCOM runs at a 5-second interval and takes several days to complete a yearlong simulation on a parallel computer cluster. As such, it was suggested that general climate change and land use change effects on flow would first be identified at Monroe, and then passed on to FVCOM for analysis which for simulating 20-day long periods. 
The 1917-2006 mean annual daily flow with the 2002 land cover is used as the baseline simulation. In order to establish the historical seasonality (the largest effect of seasonal changes in discharge) we focus on the months that, on average over the historical period, have the highest and lowest mean monthly flows (respectively the highest and lowest flow monthly climatology), corresponding to December and August at Monroe (Figure I - 4). From these flows we derive the average, maximum and minimum monthly flow, and ultimately an uncertainty range. The values for the mean monthly flow and 1917-2006 maximum and minimum monthly flows in December and August (Figure I - 4) are input into FVCOM in order to describe the FVCOM baseline. For the extreme events, the annual daily maximum/minimum flows are extracted from the 1917-2006 daily flow time series (Figure I - 5). The equivalent values are then derived for the future periods and land cover scenarios (Figure I - 6 and Figure I - 7) for input into FVCOM in order to isolate the effect of climate change and land use change over the estuary. See Table I - 6 for the experimental design.

Table I - 6: DHSVM-FVCOM Model Runs and Analysis Matrix

\begin{tabular}{|c|c|c|}
\hline Run & \multicolumn{2}{|l|}{ Run Description } \\
\hline & \multicolumn{2}{|c|}{ Historical Baseline Conditions (1917 - 2006) } \\
\hline 0 & $\begin{array}{l}\text { Average Flow Monthly } \\
\text { Climatology }\end{array}$ & Average Mean Monthly Flow (LC02;50) \\
\hline 1 & \multirow{3}{*}{$\begin{array}{l}\text { Lowest Flow Monthly } \\
\text { Climatology }\end{array}$} & Lowest Mean Monthly Flow (LC02;50) \\
\hline 2 & & Average Mean Monthly Flow (LC02;50) \\
\hline 3 & & Highest Mean Monthly Flow (LC02;50) \\
\hline 4 & \multirow{3}{*}{$\begin{array}{l}\text { Highest Flow Monthly } \\
\text { Climatology }\end{array}$} & Lowest Mean Monthly Flow (LC02;50) \\
\hline 5 & & Average Mean Monthly Flow (LC02;50) \\
\hline \multirow[t]{2}{*}{6} & & Highest Mean Monthly Flow (LC02;50) \\
\hline & \multicolumn{2}{|c|}{ Future Climate Scenarios - Focus on 2040 climate - LC02 } \\
\hline 7 & \multirow{3}{*}{$\begin{array}{l}\text { Lowest Flow Monthly } \\
\text { Climatology }\end{array}$} & Lowest Mean Monthly Flow (A1B; B1) \\
\hline 8 & & Average Mean Monthly Flow (A1B; B1) \\
\hline 9 & & Highest Mean Monthly Flow (A1B; B1) \\
\hline 10 & \multirow{3}{*}{$\begin{array}{l}\text { Highest Flow Monthly } \\
\text { Climatology }\end{array}$} & Lowest Mean Monthly Flow (A1B; B1) \\
\hline 11 & & Average Mean Monthly Flow (A1B; B1) \\
\hline 12 & & Highest Mean Monthly Flow (A1B; B1) \\
\hline & \multicolumn{2}{|l|}{ Extreme Event Scenarios } \\
\hline 13 & \multirow{4}{*}{ 90-Year Daily Return Flow } & Historical Low Flow \\
\hline 14 & & Historical High Flow \\
\hline 15 & & Climate Change Low Flow (A1B) \\
\hline 16 & & Climate Change High Flow (A1B) \\
\hline
\end{tabular}

Note:

- Effect of sea level rise was not be considered in the future climate scenario runs from DHSVM.

- DHSVM outputs include total stream flows at Monroe.

- FVCOM model outputs include water level, channel velocity and salinity fields. 


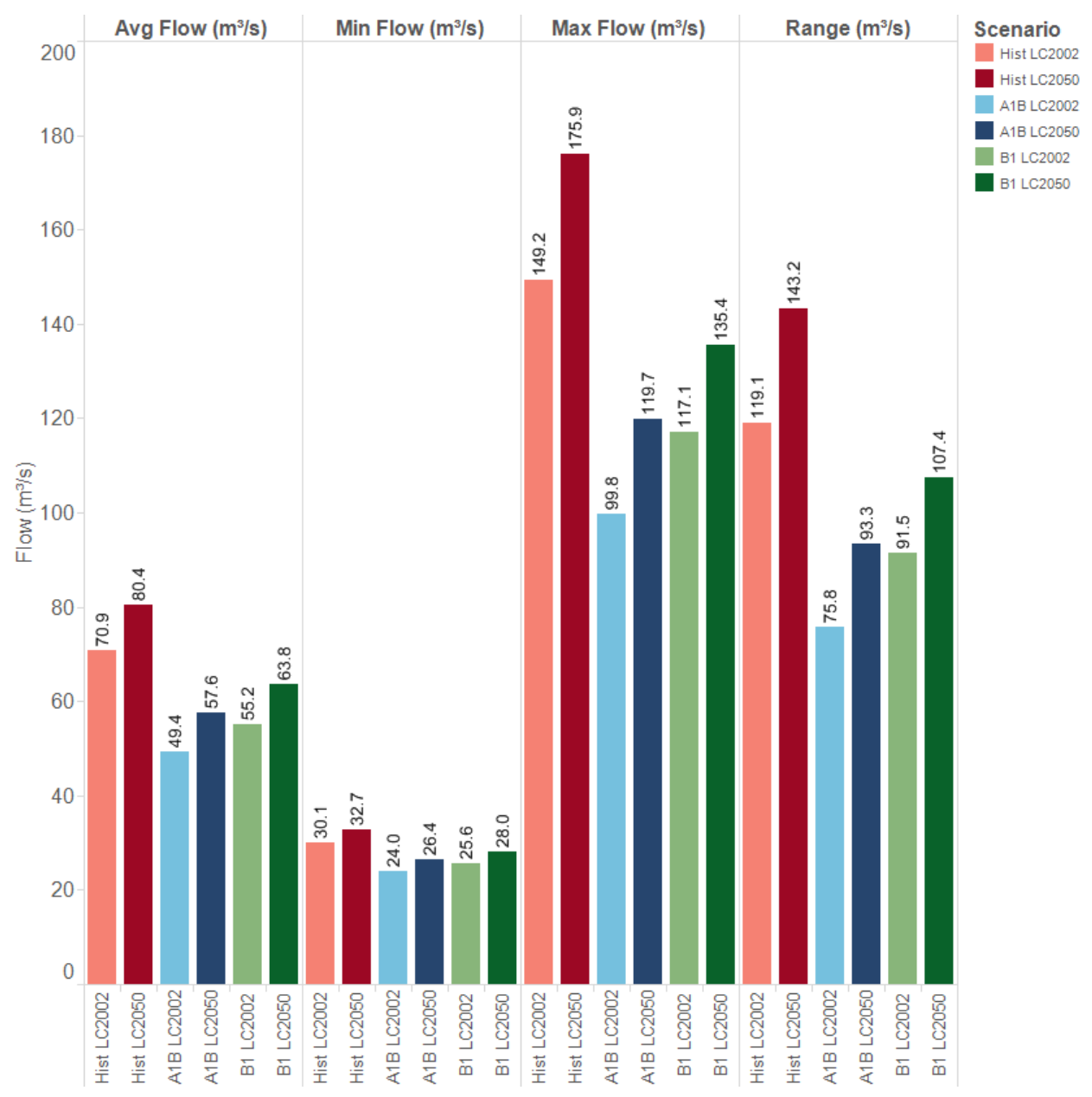

Figure I - 6: Flow statistics for Monroe in August: Climate change dominates the change in interannual variability and maximum August flow. Climate change tends to decrease the interannual monthly variability while land use change tends to increase it. 


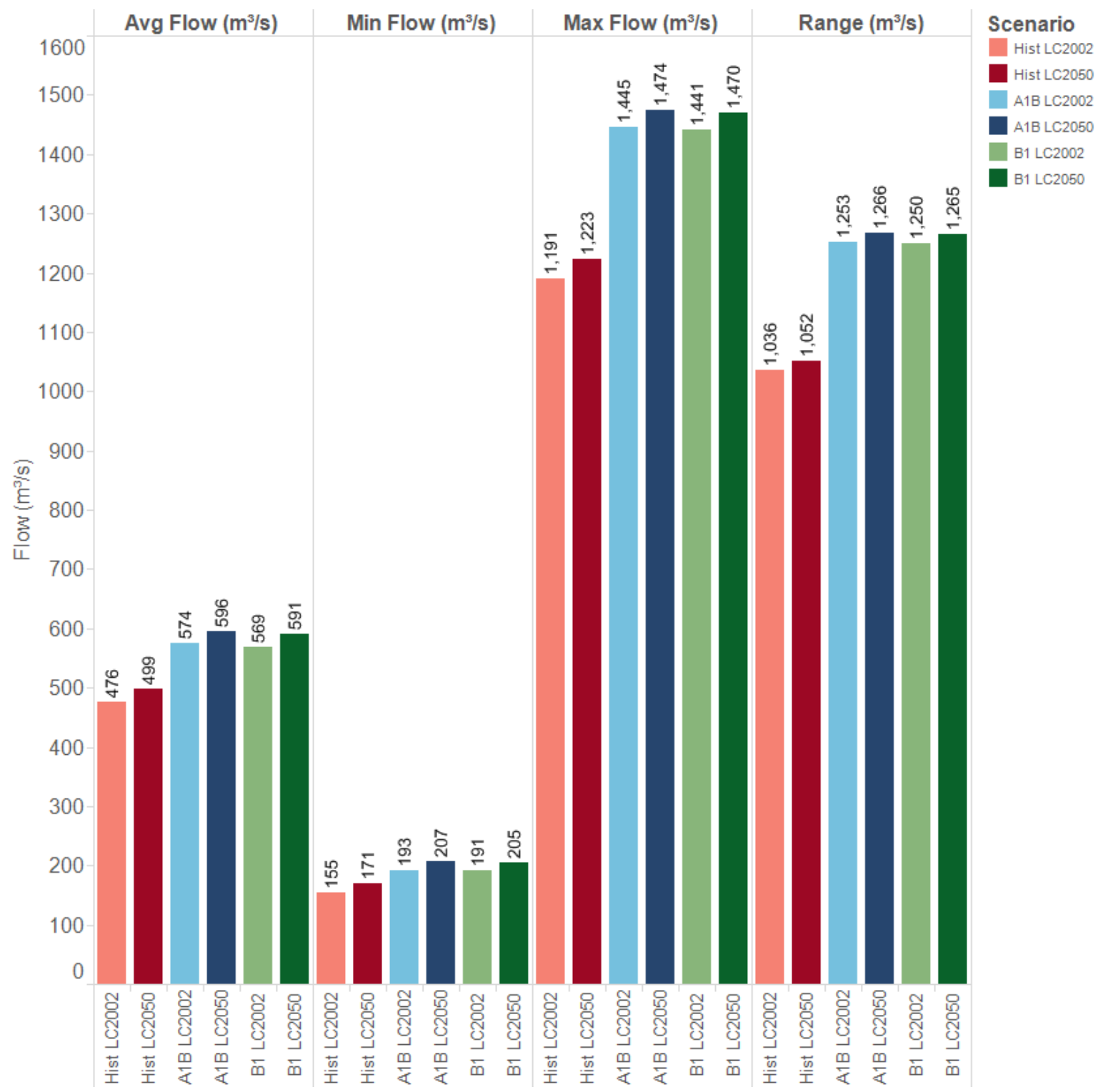

Figure I - 7: Flow statistics for Monroe in December: Climate change and land use change effects accumulate and results in an increased average flow, minimum, maximum and interannal variability in the December flow. Monthly December flow is most sensitive to climate change than to land use change.

The observed changes in streamflow at Monroe due to climate change relate to 1) changes in seasonality of the mean monthly flow, with higher fall flows due to more rain and lower summer flows; and 2) higher extreme precipitation events resulting in increased extreme daily flood magnitudes. The observed changes related to land use change at the basin scale, demonstrated by increases in the mean mean annual flow, higher snowmelt peak and higher summer flows. As explained earlier, we bound the effect of changes to the estuary by using the changes in flow for December and August. Figure I - 6 and Figure I - 7 summarize the interannual variability in the 
August and December flow. In August (lowest monthly flow of the year), climate change dominates the change in interannual variability and maximum August flow. Climate change tends to decrease the interannual variability while land use change tends to increase it and mitigate some of the effect of climate change. In December however (highest flows) climate change controls the changes; however both climate change and land use change effects accumulate and result in an increase average flow, minimum, maximum and interannual variability in the December flow. The monthly values indicate the upper and lower bounds for changes in the inflow into the estuary model.

The following flow characteristics are derived from DHSVM monthly flow time series at Monroe for input into FVCOM and displayed in Table I - 7. Because future changes in flow are dominated by changes in climate, we only ran the 2002 land cover for future periods in FVCOM.

Table I - 7: DHSVM input into FVCOM for analysis:

\begin{tabular}{|c|c|c|c|}
\hline & Validation & Flow (cms) & \\
\hline & $\begin{array}{l}\text { 1970-1980 mean daily observed (impounded), } \\
\text { dynamic land cover }\end{array}$ & 280 & \\
\hline & 1970-1980 mean daily simulated flow, LC2002 & 305 & \\
\hline Scenario & 1916-2006 historical simulation & $\begin{array}{l}\text { Flow (cms) } \\
\text { LC2002 }\end{array}$ & $\begin{array}{l}\text { Flow } \\
(\mathrm{cms}) \\
\text { LC2050 }\end{array}$ \\
\hline 0s & long term mean daily flow , LC2002 & 297 & 314 \\
\hline & highest climatological monthly flow & & \\
\hline $6 s$ & $\begin{array}{l}\text { highest monthly flow in the highest clim. } \\
\text { Monthly flow }\end{array}$ & 1190 & 1222 \\
\hline $5 s$ & $\begin{array}{l}\text { average monthly flow in the highest clim. } \\
\text { Monthly flow }\end{array}$ & 474 & 498 \\
\hline $4 s$ & $\begin{array}{l}\text { low monthly flow in the highest clim. Monthly } \\
\text { flow }\end{array}$ & 155 & 171 \\
\hline & lowest climatological monthly flow & & \\
\hline 3s & $\begin{array}{l}\text { highest monthly flow in the lowest clim. Monthly } \\
\text { flow }\end{array}$ & 149 & 176 \\
\hline $2 \mathrm{~s}$ & $\begin{array}{l}\text { average monthly flow in the lowest clim. } \\
\text { Monthly flow }\end{array}$ & 71 & 81 \\
\hline 1s & $\begin{array}{l}\text { low monthly flow in the lowest clim. Monthly } \\
\text { flow }\end{array}$ & 30 & 33 \\
\hline Scenario & $\begin{array}{l}\text { 1916-2006 simulation, LC2002, climate of the 2040s, A1B } \\
\text { emission scenario }\end{array}$ & & \\
\hline & long term mean daily flow & 303 & \\
\hline & highest climatological monthly flow & & \\
\hline 9 & $\begin{array}{l}\text { highest monthly flow in the highest clim. } \\
\text { Monthly flow }\end{array}$ & 1445 & \\
\hline 8 & $\begin{array}{l}\text { average monthly flow in the highest clim. } \\
\text { Monthly flow }\end{array}$ & 575 & \\
\hline 7 & $\begin{array}{l}\text { low monthly flow in the highest clim. Monthly } \\
\text { flow }\end{array}$ & 193 & \\
\hline
\end{tabular}




\begin{tabular}{|c|c|c|}
\hline & lowest climatological monthly flow & \\
\hline 12 & $\begin{array}{l}\text { highest monthly flow in the lowest clim. Monthly } \\
\text { flow }\end{array}$ & 100 \\
\hline 11 & $\begin{array}{l}\text { average monthly flow in the lowest clim. } \\
\text { Monthly flow }\end{array}$ & 50 \\
\hline 10 & $\begin{array}{l}\text { low monthly flow in the lowest clim. Monthly } \\
\text { flow }\end{array}$ & 24 \\
\hline \multirow[t]{3}{*}{ Scenario } & $\begin{array}{l}\text { 1916-2006 simulation, LC2002, climate of the 2040s, B1 } \\
\text { emission scenario }\end{array}$ & \\
\hline & long term mean daily flow & 303 \\
\hline & highest climatological monthly flow & \\
\hline 12 & $\begin{array}{l}\text { highest monthly flow in the highest clim. } \\
\text { Monthly flow }\end{array}$ & 1441 \\
\hline 11 & $\begin{array}{l}\text { average monthly flow in the highest clim. } \\
\text { Monthly flow }\end{array}$ & 566 \\
\hline \multirow[t]{2}{*}{10} & $\begin{array}{l}\text { low monthly flow in the highest clim. Monthly } \\
\text { flow }\end{array}$ & 191 \\
\hline & lowest climatological monthly flow & \\
\hline 9 & $\begin{array}{l}\text { highest monthly flow in the lowest clim. Monthly } \\
\text { flow }\end{array}$ & 117 \\
\hline 8 & $\begin{array}{l}\text { average monthly flow in the lowest clim. } \\
\text { Monthly flow }\end{array}$ & 55 \\
\hline 7 & $\begin{array}{l}\text { low monthly flow in the lowest clim. Monthly } \\
\text { flow }\end{array}$ & 26 \\
\hline Scenario & $\begin{array}{l}\text { 1916-2006 simulation EXTREMES ( daily } \\
\text { annual minima/maxima) LC } 2002\end{array}$ & \\
\hline 13 & historical low & 18 \\
\hline 15 & 2040s A1B low & 15 \\
\hline$(15)$ & 2040s B1 low & 16 \\
\hline 14 & historical high & 2052 \\
\hline 16 & 2040s A1B high & 2533 \\
\hline (16) & 2040s B1 high & 2518 \\
\hline
\end{tabular}

Major changes in the inundated area of the flood plain, and stream temperature trends in the estuary are controlled by tides and other long term forcing. More seasonal variations in inundated areas, stream temperature and dynamic will be impacted by climate and land use change. This evaluation can be found in the FVCOM section (Appendix II).

\section{I.3.4 Discussion - conclusion}

The Snohomish basin is a transition rain-snow basin that is projected to be very sensitive to climate change in terms of mean monthly flow climatology as more precipitation falls as rain rather than snow. The mean annual flow is not projected to change but the Fall floods are predicted to increase, snowmelt to occur earlier in the year, and Summer low flows to decrease as a results of lower snowpack. The land use 
is projected to consist of urbanization around Monroe and transition from forest to shrubs at the foot of the mountains. The effect of land use change focuses on the increase of the mean annual flow due to decreased evapotranspiration, and therefore increase Summer flow. The opportunities to mitigate climate change through land use is on the Summer flow characteristics, which in turn would improve water quality. Table I - 8 summarizes the effect of land use change at the basin scale over the Snohomish Basin.

Table I - 8: summary of land use change and climate change effects on flow at Monroe

\begin{tabular}{|llll|}
\hline & Projected future land use & Project future climate & Dominant driver \\
\hline Mean annual flow & Increase (6\%) & Uncertain (2\%) & Land Use \\
\hline Daily flow variability & Decrease (-3\%) & Increase (18\%) & Climate Change \\
\hline Extreme annual daily flood & No effect & Increase & Climate change \\
\hline Low annual daily flood & No effect & Increase & Climate Change \\
\hline 7-day minimum flow & Increase (13-15\%) & Decrease (-16;-23\%) & Climate Change \\
\hline Snowmelt timing & No effect & Earlier & Climate change \\
\hline
\end{tabular}




\section{I.4 Effect of changes in land use and climate over the upper Snohomish basins, with application to habitat restoration}

Examining the rain-snow dominated Snohomish Basin (Monroe) at the basin-scale shows that climate change is the dominant source of change in predicted flows over that of land use. A significant land use change was observed between 2002 and 2007 in the upstream Snohomish Basin (King County, personal communication, September 2012). The sub basins of interest for this study are: 1) West Woods Creek; 2) South fork of the Skykomish River; and 3) the north fork of the Snoqualmie River. These basins differ from one another in terms of placement within the basin, precipitation patterns, and the altitude at which they occur. Woods Creek is rain dominated; the Skykomish is snowmelt dominated; while the Snoqualmie is a transition rainsnow basin (Figure I - 8). In order to more accurately assess the impact of land use and climate change over upstream basins for habitat restoration purposes , the 2002 land cover map was updated. More accuracy in the land cover is expected to increase accuracy in the hydrologic simulations at smaller spatial scales, i.e. over the 3 subbasins of interest.

The scientific questions addressed by this study are: 1) what is the effect of forest practices / recent land use changes on the hydrology of the North Fork of the Snoqualmie River, South Fork of Skykomish and West Woods Creek? And 2) what is the sensitivity of the hydrology to land use change / forest practices in order to help define a plan for stream restoration?

The experimental approach used forces the distributed hydrology model DHSVM with historical and future climate using current and a synthetical land cover maps and focuses on particular subbasins of interest. The University of Washington generated a 2007 land cover map, which was adjusted to the 2002 land classes (See previous sections). The 2007 land cover map was adjusted into a "mature 2007" land cover map to represent a land cover with urbanization but without forest management. We analysis potential changes over the long term mean monthly flow climatology, annual daily flood events, and specific metrics for application to restoration. The following sections present the development of the unmanaged forest land cover, the restoration metrics and finally the analysis.

\section{I.4.1 The 2007 land use maps}

The 2007 vegetation cover maps were derived similarly to the 2002 land cover maps (Alberti et al. 2004). Central Puget Sound 2007 Landcover was obtained from the Urban Ecology

Research Laboratory (Central Puget Sound 2007 Land Cover Classification. Puget Sound Regional Synthesis Model (PRISM). University of Washington) See:

http://urbaneco.washington.edu/wp/resources/data/. This 30m dataset of landcover classifications was resampled to meet the $150 \mathrm{~m}$ scale of DHSVM. Vegetation classes differ from the original 2002 classes description; the 2007 land cover maps were translated into 2002 vegetation classes in order to ensure consistency in the DHSVM calibration parameters. Table I - 9 presents the equivalent 2007 and 2002 vegetation classes, based on the description of the classes. Figure I - 8 shows the impact of changing from the 2002 to 2007 land cover on the monthly hydrograph of 
the basins of interest; none of the previous conclusions would change but results are more accurate as the land cover is more recent.

Table I - 9: Updated 2007 land cover vegetation class and correspondence with DHSVM classes

\begin{tabular}{llll}
\hline County Classes 2007 Values & Class & PNNL class & PNNL class description \\
\hline Bare Ground / Clear Cut & 1 & 3 & Bareground \\
Grass/Shrubs/Crops/Early Regrowth & 2 & 6 & grass crop shrub \\
Deciduous/Mixed Forest & 4 & 7 & mixed/deciduous forest \\
Water & 5 & 14 & Water \\
Mature Coniferous Forest & 6 & $\mathbf{8}$ & conifer forest \\
Snow/lce & 8 & 11 & Rocks \\
Open Forest/Regrowth & 10 & $\mathbf{5}$ & Native grass \\
Low Density Urban & 12 & 2 & light medium urban \\
High Density Urban & 13 & $\mathbf{1}$ & dense urban \\
\hline Medium Density Urban & 14 & $\mathbf{2}$ & light medium urban \\
Agriculture & 15 & $\mathbf{6}$ & grass crop shrub \\
Wetland & 16 & $\mathbf{1 2}$ & Wetland \\
\hline
\end{tabular}




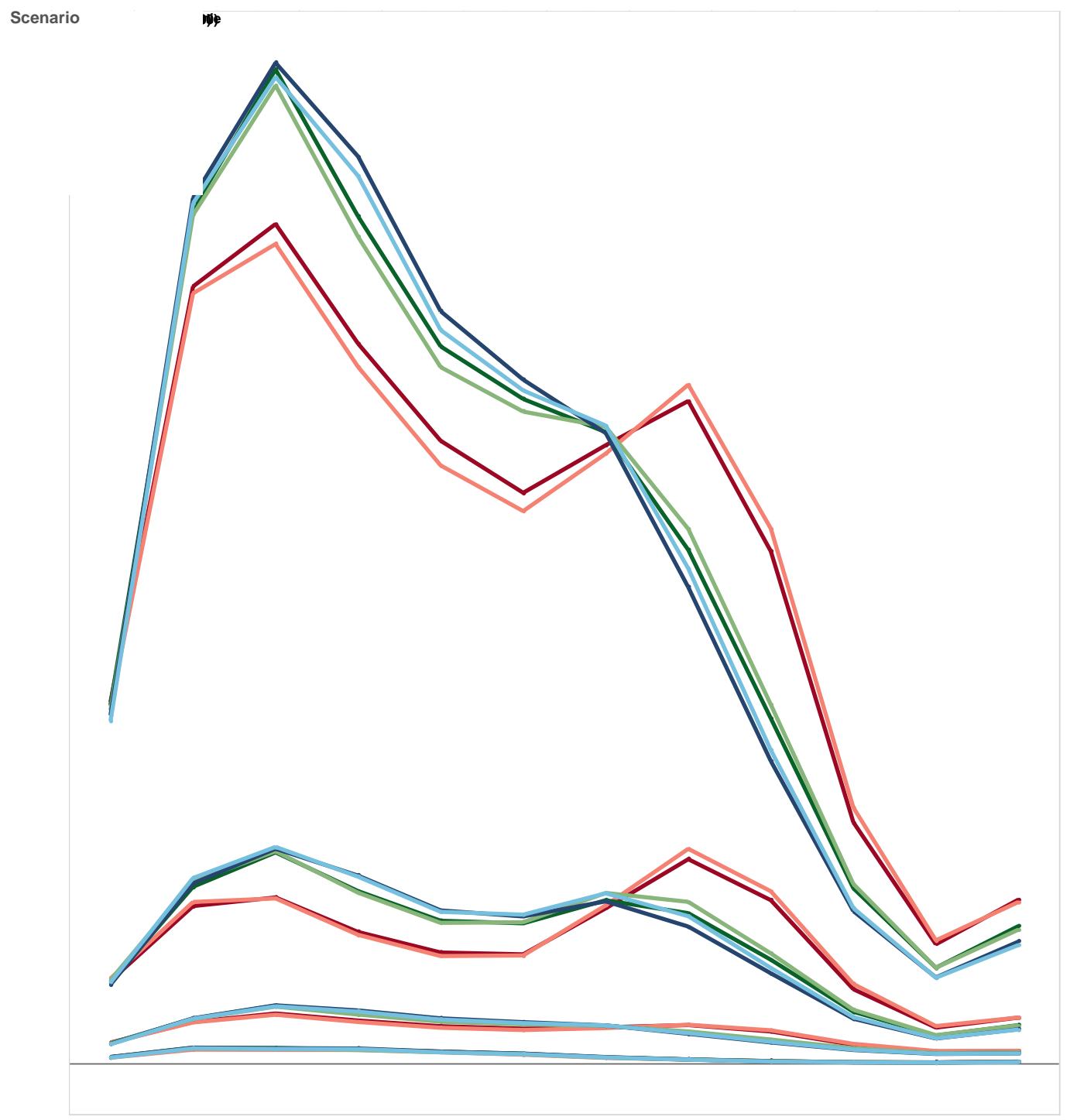

Figure I - 8: Effect of updating the land cover over the mean monthly hydrograph over the Snohomish River (Monroe), and subbasins of interest; South Fork of the Skykomish, North Fork of Snoqualmie and West Woods Creek. Close ups of individual basins can be found in the final section of this appendix.

The managed forest scenario is represented by the 2007 land cover. The unmanaged mature forest is represented by a 2007 - mature land cover (2007M hereafter) developed for this project. The snowline is a good break ( 4000 feet) to differentiate between forests that would develop mature forest characteristics from forest that would not. In the central Cascades the break between the Silver Fir zone and the Mountain Hemlock zone occurs at about the 4,000 foot elevation. Forest in the Mountain Hemlock zone typically will not develop into mature forest as we have characterized them. Above the snowline, the vegetation cover of 2007-mature remains unchanged. Below the snowline, the vegetation cover is modified as described; and a new "mature coniferous forest" vegetation class was added which consists of the initial and conserved "coniferous forest" with tree tops 55 meters high rather than 43 meters. 
The following 2007 land cover classes present below the snowline were combined into our new mature coniferous forecast classes:

- Grass/shrubs/crops/early regrowth

- Deciduous/mixed forest

- Open forest/regrowth

- Bare ground/clearcut

- Mature Coniferous Forest

The urban class was not modified because we assume that even under different forest management, the urban area would remain the same.

Vegetation classes were combined to create the mature forest vegetation cover scenario in all areas below the snowline within the forest production district which excludes a small southwest corner of the Lower North Fork Snoqualmie sub basin that is outside the forest production district (King County data). Current rural-residential-agriculture is highly unlikely to convert to mature forest.

\section{I.4.2 Stream restoration metrics}

The purpose for the analysis of the impact of land use change and climate change on the upper Snohomish Basin is to support stream restoration for salmon and other natural resources.

Changes in mean monthly hydrographs and mean annual daily floods are the basis for isolating the effects of climate change and land use changes, building off other analysis in the same region (Cuo et al. 2011). In addition, for the specific purpose of stream restoration the metrics presented in Table I - 10 are evaluated for different climate and land use scenarios. These metrics are derived through the USGS's Hydrological Index Tool (HIT) software. (http://www.fort.usgs.gov/Products/Software/NATHAT/). USGS software HIT (http://www.fort.usgs.gov/Products/Publications/21598/21598.pdf). Note that for more complete information to derive a stream restoration plan, the hydrologic response to land use change should be complemented by both a water quality sensitivity analysis and analysis of changes in water resources management practices associated with land use change. The present simulations are for natural flow only. 
Table I - 10: Hydrologic indices for comparing flow regimes. These indices and their codes are commonly used in existing analyses tools, including the Hydrologic Index Tool (USGS)

\begin{tabular}{|c|c|c|}
\hline Code & Hydrologic Index & Definition \\
\hline Ma1 & Mean daily flow & Mean daily flow for the period of record \\
\hline Ma2 & Median daily flow & Median daily flow for the period of record \\
\hline Ma3 & Variability in daily flows & Coefficient of variation in daily flows \\
\hline Ma12-23 & Mean (or median) monthly flow & Mean (or median) monthly flow for all months \\
\hline Ml1-12 & Mean minimum monthly flows & Mean minimum monthly flow for all months \\
\hline Ml13 & $\begin{array}{l}\text { Variability across minimum } \\
\text { monthly flows }\end{array}$ & $\begin{array}{l}\text { Coefficient of variation in minimum monthly } \\
\text { flows }\end{array}$ \\
\hline Mh1-12 & Mean maximum monthly flows & Mean maximum monthly flow for all months \\
\hline Mh13 & $\begin{array}{l}\text { Variability across maximum } \\
\text { monthly flows }\end{array}$ & $\begin{array}{l}\text { Coefficient of variation in maximum monthly } \\
\text { flows }\end{array}$ \\
\hline Fl1 & Low flood pulse count & $\begin{array}{l}\text { Number of occurrences for each year of the } \\
\text { period of record during which the magnitude } \\
\text { of flow is less than the } 25^{\text {th }} \text { percentile of all } \\
\text { daily flow values for the time period }\end{array}$ \\
\hline $\mathbf{F l 2}$ & Variability in low flood pulse count & Coefficient of variation in $\mathrm{Fl} 1$ \\
\hline Fh1 & High flood pulse count & $\begin{array}{l}\text { Number of occurrences for each year of the } \\
\text { period of record during which the magnitude } \\
\text { of flow is greater than the 75th percentile of } \\
\text { all daily flow values for the time period }\end{array}$ \\
\hline Fh2 & $\begin{array}{l}\text { Variability in high flood pulse } \\
\text { count }\end{array}$ & Coefficient of variation in Fh1 \\
\hline DI3 & $\begin{array}{l}\text { Annual minimum of } 7 \text {-day means } \\
\text { of daily discharge }\end{array}$ & $\begin{array}{l}\text { Magnitude of the minimum 7-day mean flow } \\
\text { for each year of the period of record }\end{array}$ \\
\hline Dh3 & $\begin{array}{l}\text { Annual maximum of 7-day means } \\
\text { of daily discharge }\end{array}$ & $\begin{array}{l}\text { Magnitude of the maximum 7-day mean flow } \\
\text { for each year of the period of record }\end{array}$ \\
\hline TI1 & Julian date of annual minimum & $\begin{array}{l}\text { The mean Julian date of the 1-day annual } \\
\text { minimum flow over all years }\end{array}$ \\
\hline TI2 & $\begin{array}{l}\text { Variability in Julian date of annual } \\
\text { minimum }\end{array}$ & Coefficient of variation in Tl1 \\
\hline Th1 & Julian date of annual maximum & $\begin{array}{l}\text { The mean Julian date of the 1-day annual } \\
\text { maximum flow over all years }\end{array}$ \\
\hline Th2 & $\begin{array}{l}\text { Variability in Julian date of annual } \\
\text { maximum }\end{array}$ & Coefficient of variation in Th1 \\
\hline
\end{tabular}




\section{I.4.3 Model set up for examining subbasins of interest}

In order to examine the three subbasins of interest (West Wood Creek, South form of the Skykomish, North fork of the Snohomish) the following scientific questions were posed: 1) what is the effect of forest practices / recent land use changes on the hydrology of the North Fork of the Snoqualmie River, South Fork of Skykomish and West Woods Creek? 2) what is the sensitivity of the hydrology to land use change / forest practices in order to help define a plan for stream restoration?

In order to address these questions, the following hydrologic modeling scenarios were developed (Figure I - 9):

(1) Historical flow simulation using LC2007

(2) Historical flow simulation using LC2007M

(3) Future flow simulations using LC2007

(4) Future flow simulations using LC2007M

Evaluating modeling scenario (1) with (2), and modeling scenario (3) with (4) allows for isolating the effect of forest practices (LC2007) with respect to the hypothetical unmanaged forest (LC2007M) under current and future conditions, respectively. In the following sections we report on the isolation of the effects of land use under current conditions by analyzing the effect on the mean monthly hydrograph, annual daily flood cumulative density function, and restoration metrics. We then perform the same analysis under future climate conditions, for each of the three subbasins of interest. 


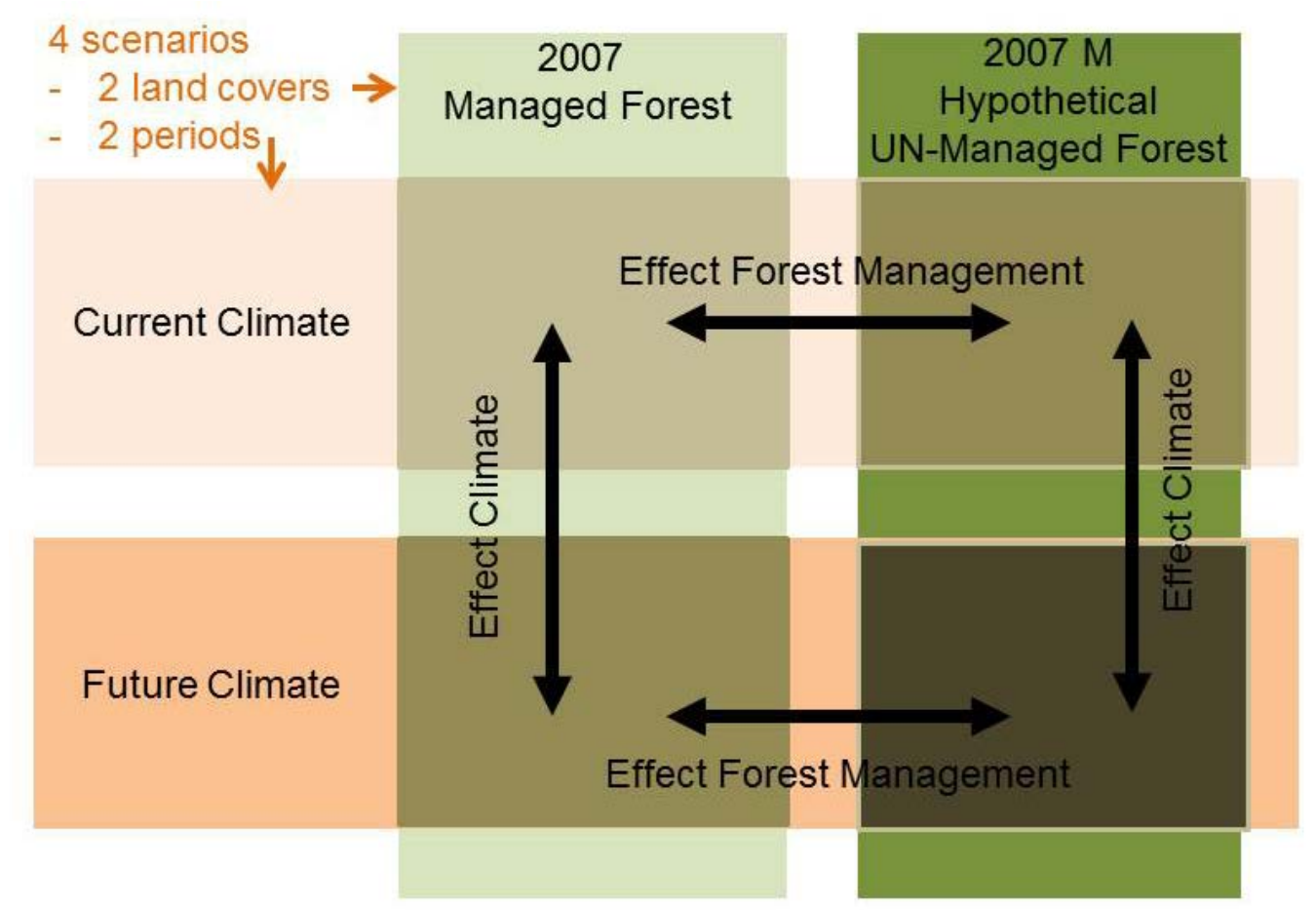

Figure I - 9: Experimental Design to isolate effects of climate and land use changes

\section{I.4.4 Results}

Each of the subbasin of interest was evaluated independently as each of them represents a different hydro-climatological condition: rain dominated (West Wood Creek), rain-snow dominated (South fork of the Skykomish) and snowmelt-dominated (North fork of the Snoqualmie).

\section{I.4.4.1 West Wood Creek}

West Woods Creek is a rain dominated basin (Figure I - 10) as shown by the one peak hydrograph overlapping the fall and winter seasons. The mean monthly flow climatology is more sensitive to change in land use than climate change, which is in agreement with Cuo et al. (2011). With the 2007 mature forest, the overall annual daily flow is significantly lower (-29\%) with an equivalent summer flow but a much lower fall and winter flow due to interception of precipitation by the forest canopy and higher evapotranspiration losses. The effect of climate change on annual daily floods is equivalent for both land covers with a slight increase shown (Figure I - 11). Land use disturbances dominate the changes in annual daily flood. With a mature forest, the annual daily flood would be lower on both sides of the tails (short and long return periods). Note that the flow is very low in the basin so that sensitivity analyses has a degree of uncertainty; some metrics provided by HIT (Table I - 11) could not be derived with confidence due to null flows on occasion. 


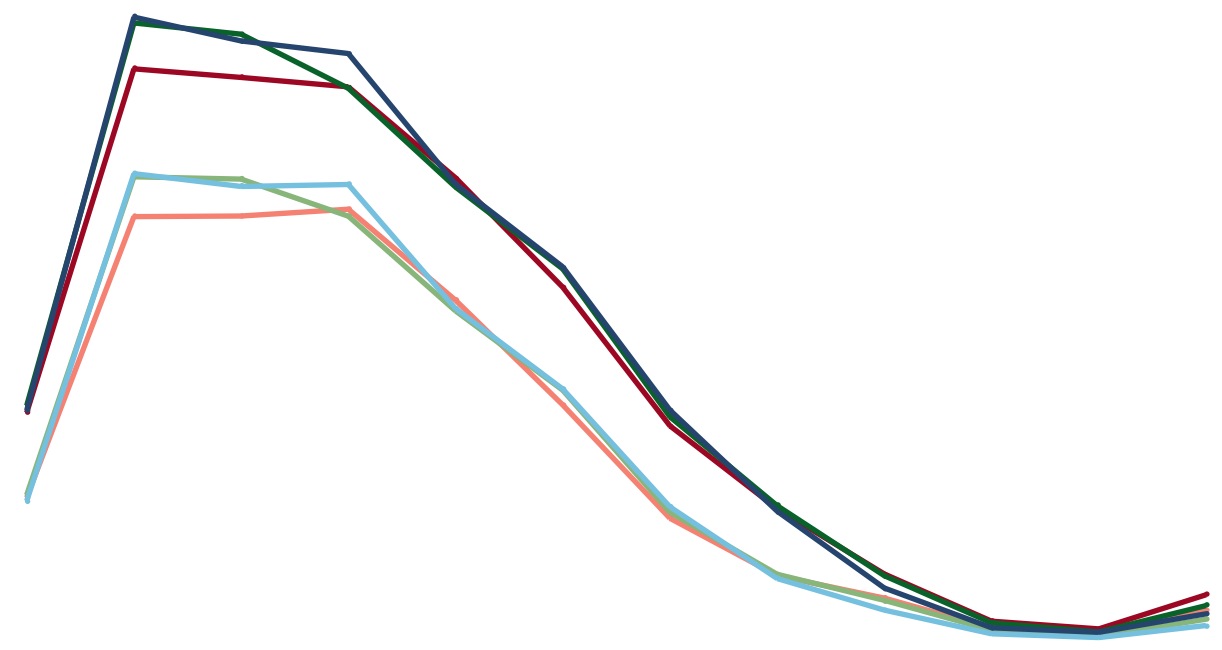

Figure I - 10: Monthly flow hydrograph at West Woods Creek under current managed forest (LC2007) and hypothetical unmanaged forest (LC2007M) under current (historical) and future (A1B, B1) climate conditions. 
Table I - 11: HIT metrics for West Woods Creek

\begin{tabular}{|c|c|c|c|c|c|c|c|c|c|c|c|c|c|}
\hline Climate Scenario & $\mathrm{A} 1 \mathrm{~B}$ & $\mathrm{~A} 1 \mathrm{~B}$ & $\mathrm{~B} 1$ & B1 & Hist. & Hist. & Land C & over Eff & & Clim & e Cha & ge Eff & \\
\hline Land Cover Scenario & $\begin{array}{l}\text { 今 } \\
\text { N } \\
\text { U }\end{array}$ & 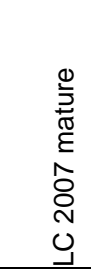 & $\begin{array}{l}\text { ¿ } \\
\stackrel{2}{N} \\
0 \\
\end{array}$ & 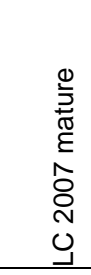 & $\begin{array}{l}\text { 옹 } \\
\text { N } \\
0\end{array}$ & 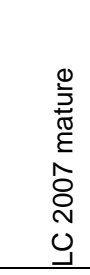 & $\begin{array}{l}\sum \\
0 \\
0 \\
0 \\
\infty \\
\hat{0} \\
0 \\
0 \\
\dot{1} \\
\frac{1}{4}\end{array}$ & 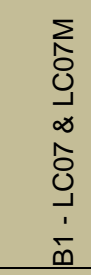 & 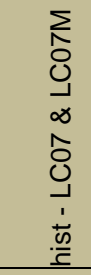 & 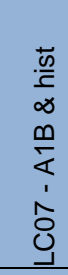 & 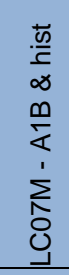 & 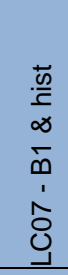 & 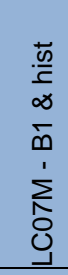 \\
\hline Mean Daily Flow & 3.8 & 2.7 & 3.8 & 2.7 & 3.7 & 2.6 & $-29 \%$ & $-29 \%$ & $-29 \%$ & $4 \%$ & $3 \%$ & $3 \%$ & $3 \%$ \\
\hline Median Daily Flow & 1 & 0 & 1 & 1 & 1 & 1 & $\mathrm{~N} / \mathrm{A}$ & $\mathrm{N} / \mathrm{A}$ & $\mathrm{N} / \mathrm{A}$ & $\mathrm{N} / \mathrm{A}$ & $\mathrm{N} / \mathrm{A}$ & $\mathrm{N} / \mathrm{A}$ & $\mathrm{N} / \mathrm{A}$ \\
\hline $\begin{array}{l}\text { Variability in Daily } \\
\text { Flows }\end{array}$ & 153.3 & 179.5 & 151.8 & 177.4 & 151.5 & 176.6 & $17 \%$ & $17 \%$ & $17 \%$ & $1 \%$ & $2 \%$ & $0 \%$ & $0 \%$ \\
\hline $\begin{array}{l}\text { Variability across } \\
\text { Minimum Monthly } \\
\text { Flows }\end{array}$ & 319 & 430 & 323 & 437 & 334 & 450 & $35 \%$ & $36 \%$ & $35 \%$ & $-4 \%$ & $-4 \%$ & $-3 \%$ & $-3 \%$ \\
\hline $\begin{array}{l}\text { Variability across } \\
\text { Maximum Monthly } \\
\text { Flows }\end{array}$ & 87.4 & 98.6 & 85.3 & 96.2 & 84.3 & 94.7 & $13 \%$ & $13 \%$ & $12 \%$ & $4 \%$ & $4 \%$ & $1 \%$ & $2 \%$ \\
\hline $\begin{array}{l}\text { Low Flood Pulse } \\
\text { Count }\end{array}$ & 0 & 0 & 0 & 0 & 0 & 0 & 0.0 & 0.0 & 0.0 & 0.0 & 0.0 & 0.0 & 0.0 \\
\hline $\begin{array}{l}\text { Variability in Low } \\
\text { Flood Pulse Count }\end{array}$ & $\mathrm{NC}$ & $\mathrm{NC}$ & $\mathrm{NC}$ & $\mathrm{NC}$ & $\mathrm{NC}$ & $\mathrm{NC}$ & $\mathrm{N} / \mathrm{A}$ & $\mathrm{N} / \mathrm{A}$ & $\mathrm{N} / \mathrm{A}$ & $\mathrm{N} / \mathrm{A}$ & $\mathrm{N} / \mathrm{A}$ & $\mathrm{N} / \mathrm{A}$ & $\mathrm{N} / \mathrm{A}$ \\
\hline $\begin{array}{l}\text { High Flood Pulse } \\
\text { Count }\end{array}$ & 14 & 13 & 15 & 14 & 15 & 14 & -0.8 & -0.8 & -0.9 & -0.6 & -0.5 & -0.2 & -0.1 \\
\hline $\begin{array}{l}\text { Variability in High } \\
\text { Flood Pulse Count }\end{array}$ & 22 & 23 & 22 & 23 & 23 & 25 & 1.5 & 0.6 & 1.7 & -1.1 & -1.3 & -0.8 & -1.9 \\
\hline $\begin{array}{l}\text { Annual minimum of } \\
\text { 7-day means of daily } \\
\text { discharge }\end{array}$ & 0 & 0 & 0 & 0 & 0 & 0 & $\mathrm{~N} / \mathrm{A}$ & $\mathrm{N} / \mathrm{A}$ & $\mathrm{N} / \mathrm{A}$ & $\mathrm{N} / \mathrm{A}$ & $\mathrm{N} / \mathrm{A}$ & N/A & $\mathrm{N} / \mathrm{A}$ \\
\hline $\begin{array}{l}\text { Annual maximum of } \\
\text { 7-day means of daily } \\
\text { discharge }\end{array}$ & 23.3 & 20.2 & 23.0 & 19.8 & 22.3 & 19.2 & $-14 \%$ & $-14 \%$ & $-14 \%$ & $5 \%$ & $5 \%$ & $3 \%$ & $3 \%$ \\
\hline $\begin{array}{l}\text { Julian date of annual } \\
\text { minimum }\end{array}$ & 277 & 275 & 277 & 275 & 277 & 276 & -1.5 & -1.8 & -1.3 & -0.7 & -0.9 & -0.1 & -0.5 \\
\hline $\begin{array}{l}\text { Variability in Julian } \\
\text { date of annual } \\
\text { minimum }\end{array}$ & 10 & 4 & 11 & 5 & 11 & 5 & -6.2 & -6.4 & -5.5 & -0.6 & -1.3 & -0.1 & -0.9 \\
\hline $\begin{array}{l}\text { Julian date of annual } \\
\text { maximum }\end{array}$ & 358 & 361 & 358 & 359 & 360 & 363 & 3.4 & 1.1 & 2.7 & -2.5 & -1.7 & -2.4 & -4.0 \\
\hline $\begin{array}{l}\text { Variability in Julian } \\
\text { date of annual } \\
\text { maximum }\end{array}$ & 37 & 37 & 37 & 37 & 38 & 38 & -0.1 & 0.4 & 0.0 & -1.0 & -1.0 & -1.0 & -0.6 \\
\hline
\end{tabular}


Scenario

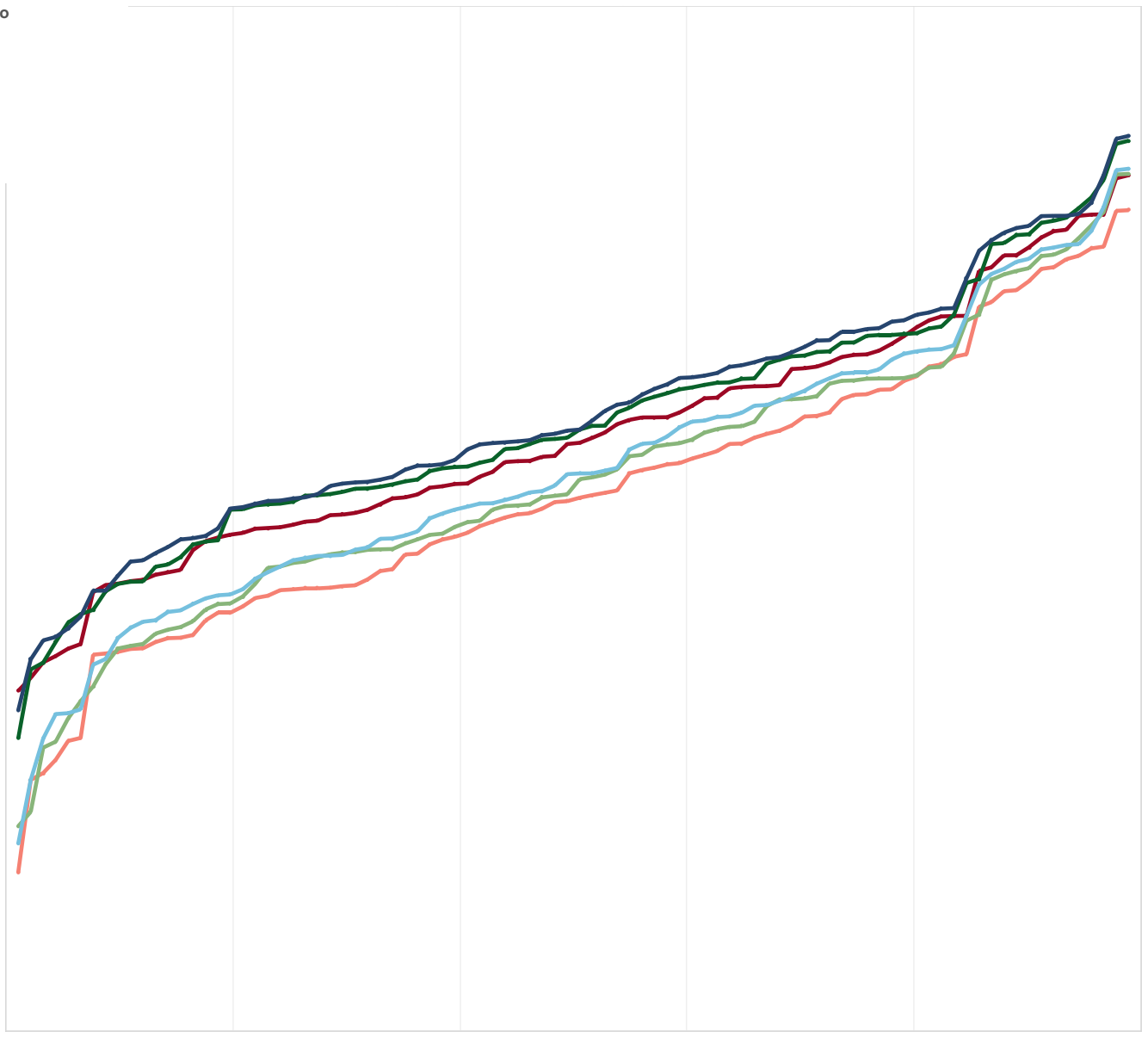

Figure I - 11: Annual daily flood cumulative density function for West Woods Creek for current managed forest (LC2007) and hypothetical unmanaged forest (LC2007M) under current (historical) and future (A1B, B1) climate conditions. 


\section{I.4.4.2 South Fork of the Skykomish:}

The South Fork of the Skykomish is a rain-snow transition basin but tending towards snowmelt-controlled, as shown by the historical mean monthly climatology which displays a higher snowmelt peak flow than the fall flow (Figure I - 12). Climate change is the predominant driver of change in the mean monthly flow climatology, decreasing the snowmelt peak and increasing the fall flow peak, bringing the basin to a rain-snow transition basin but more highly controlled by rain, with snowmelt occurring earlier. The coefficient of variation (monthly flow variability) for high and low flows increase (Table I - 12) and the overall mean annual flow does not change. Mature forest in the subbasin will not change the seasonality of the flow but the annual mean annual flow will decrease by about 6\% during the lower high flow season.

Climate change is predicted to increase the annual daily floods for long and medium return period and to decrease the floods with short return periods (Figure I - 13). The 7-day low flow minimum is predicted to decrease by $18 \%$ to $26 \%$ depending on the climate change emission scenario. A mature forest does not dominate the change in annual daily flood. Very long return period floods are not affected by land use changes; however medium and short return period annual daily floods will decrease. 


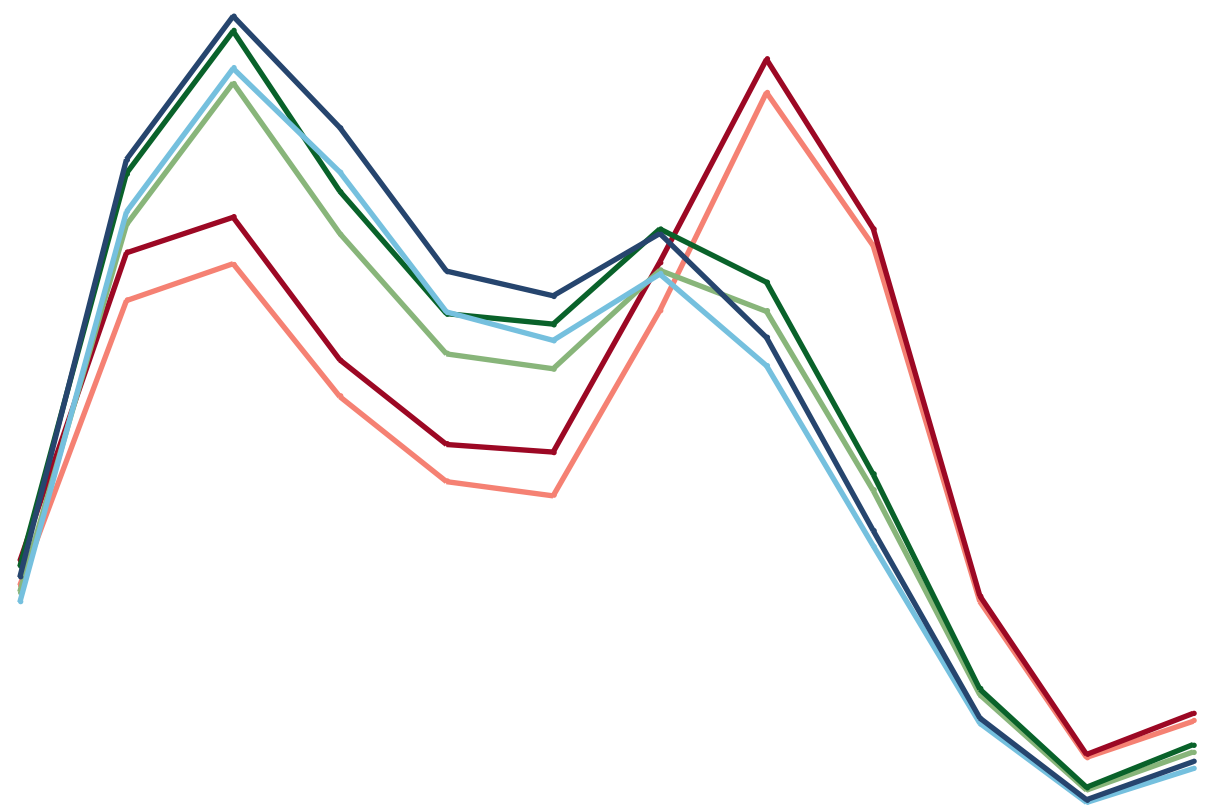

Figure I - 12: Monthly flow hydrograph for the South Fork of the Skykomish River under current managed forest (LC2007) and hypothetical unmanaged forest (LC2007M) under current (historical) and future (A1B, B1) climate conditions. 
Table I - 12: HIT metrics for the South Fork of the Skykomish

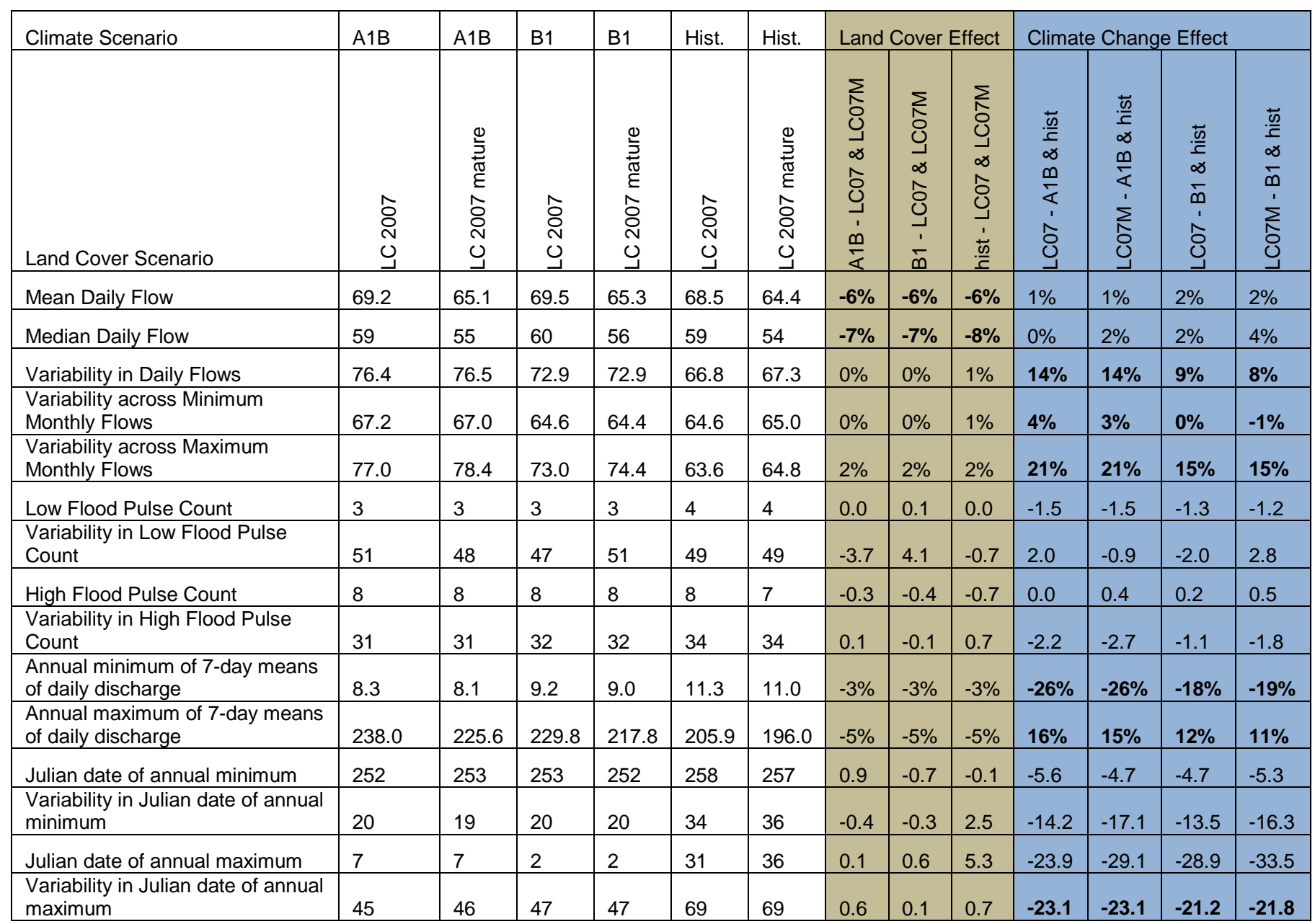




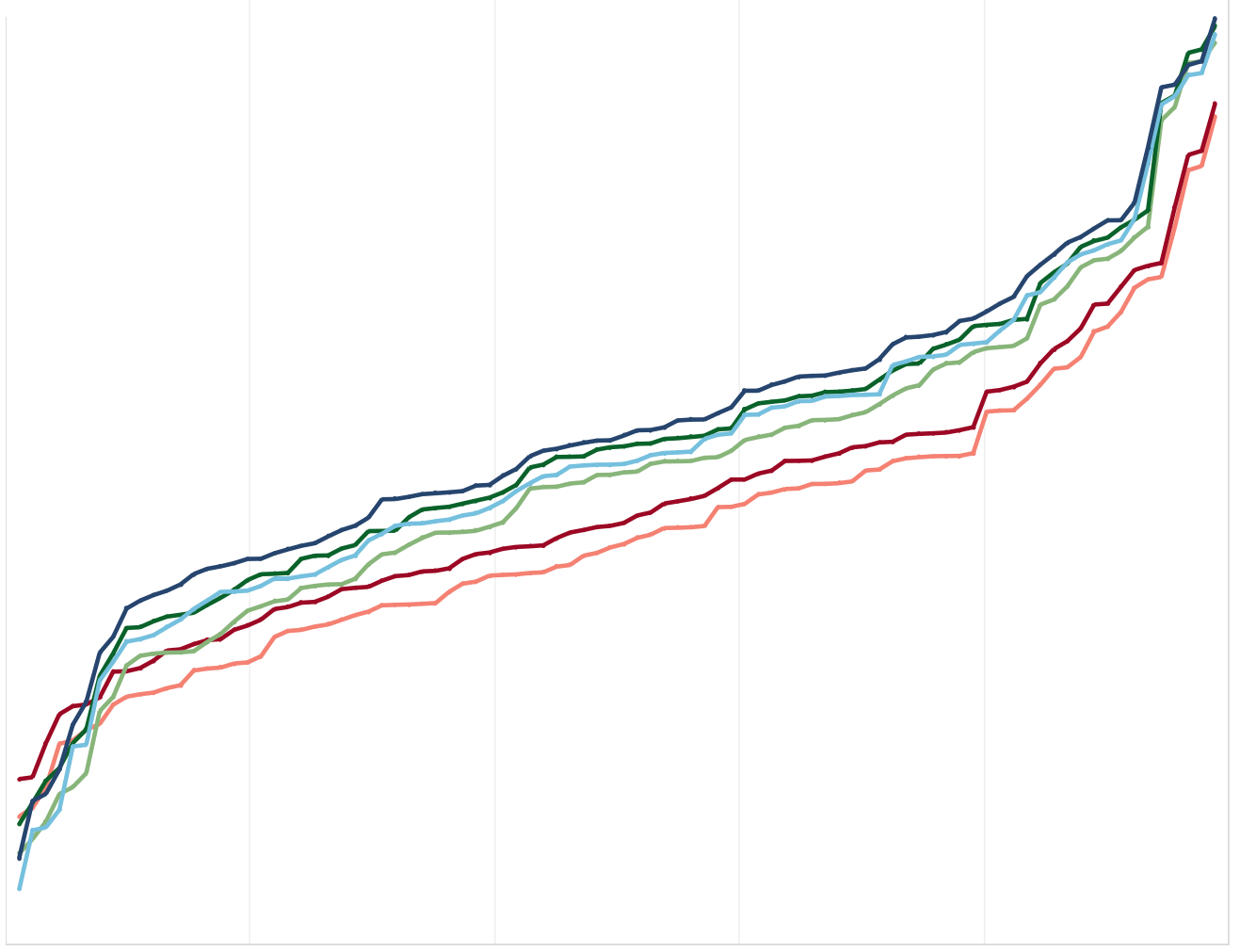

Figure I - 13: Annual daily flood cumulative density function for the South Fork of the Skykomish for current managed forest (LC2007) and hypothetical unmanaged forest (LC2007M) under current (historical) and future (A1B, B1) climate conditions. 


\section{I.4.4.3 North Fork of the Snoqualmie Basin:}

The North Fork is a rain-snow transition basin. The mean monthly flow climatology is projected to be affected significantly by both climate and land use changes (Figure I - 14). Climate change is predicted to change the seasonality of the flow, decreasing the snowmelt peak as more precipitation falls as rain, and to increase the fall peak, with snowmelt occurring earlier. The overall mean annual flow will be maintained (2\%) but the monthly flow variability for low and high flow will increase (Table I - 13). The minimum 7-day low flow will decrease by $13 \%$ to $17 \%$ depending on the emission scenario. A mature forest would not change the seasonality of the flow but will affect the mean annual flow, decreasing it by $14 \%$, especially during the fall and spring high flow seasons. The minimum 7-day low flow will not be affected.

As shown in Figure I - 14, the annual daily flood is affected by both climate change and forest management, but only for the low and medium spectrum of the annual daily flood.

Extreme annual daily floods are projected to increase due to climate change, but are not sensitive to the forest management practices. 


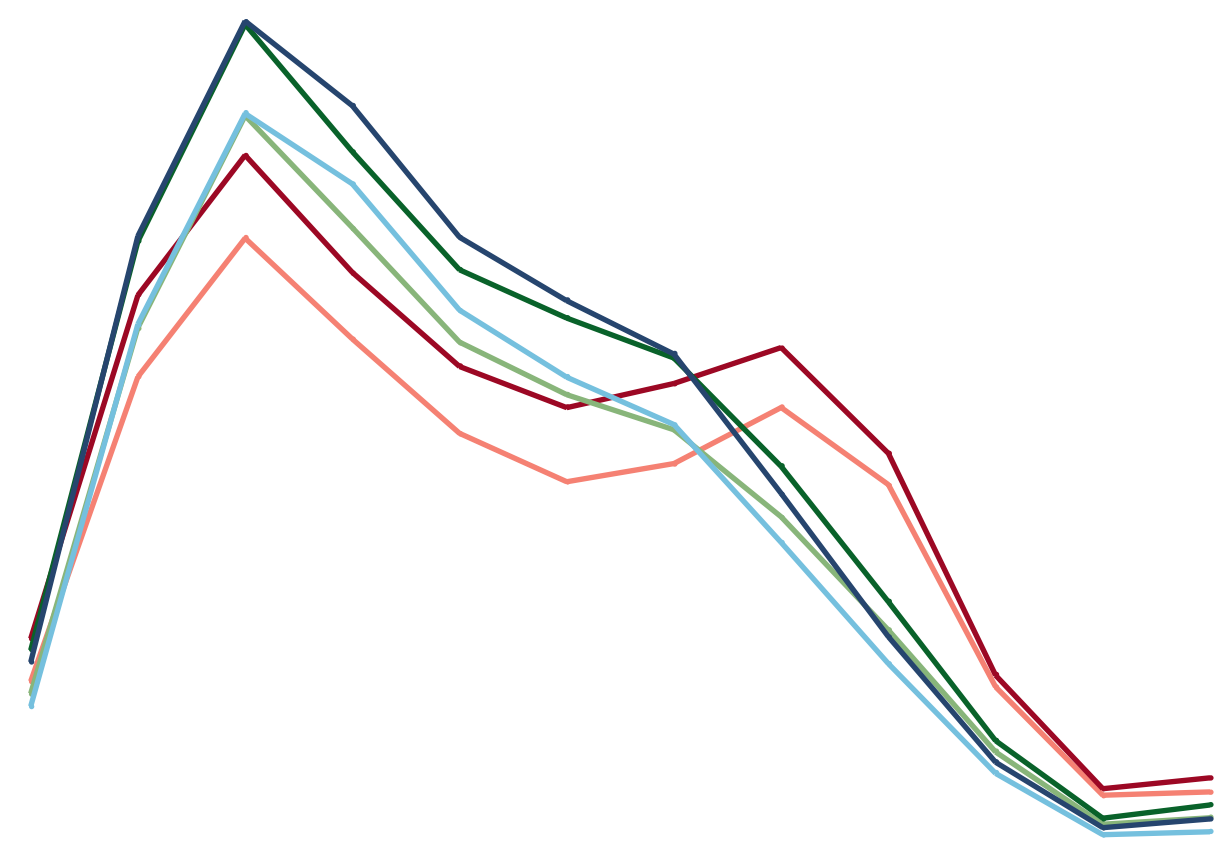

Figure I - 14: Monthly flow hydrograph for the North Fork of the Snoqualmie River under current managed forest (LC2007) and hypothetical unmanaged forest (LC2007M) under current (historical) and future (A1B, B1) climate conditions. 
Table I - 13: HIT metrics for the North Fork of the Snoqualmie River

\begin{tabular}{|c|c|c|c|c|c|c|c|c|c|c|c|c|c|}
\hline Climate Scenario & A1B & A1B & B1 & B1 & Hist & Hist & Land $\mathrm{C}$ & over Ef & & Clima & Chang & Effect & \\
\hline Land Cover Scenario & $\begin{array}{l}\hat{8} \\
\text { O } \\
\text { U }\end{array}$ & 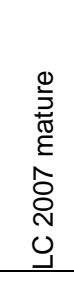 & $\begin{array}{l}\hat{̊} \\
\text { Oे } \\
0 \\
\end{array}$ & 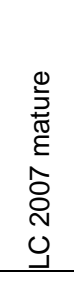 & $\begin{array}{l}\hat{\circ} \\
\stackrel{N}{N} \\
0\end{array}$ & 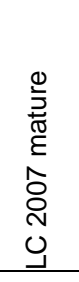 & 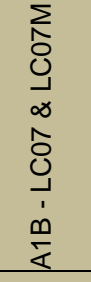 & 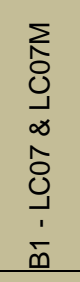 & 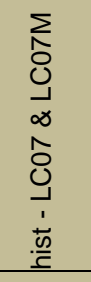 & 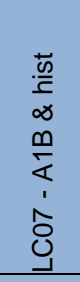 & 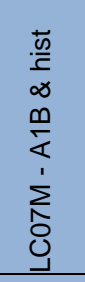 & 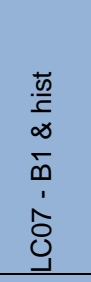 & 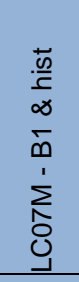 \\
\hline Mean Daily Flow & 17.9 & 16.1 & 17.9 & 16.1 & 17.6 & 15.8 & $-10 \%$ & $-10 \%$ & $-10 \%$ & $2 \%$ & $2 \%$ & $2 \%$ & $2 \%$ \\
\hline Median Daily Flow & 15 & 13 & 15 & 13 & 16 & 14 & $-13 \%$ & $-13 \%$ & $-13 \%$ & $-6 \%$ & $-7 \%$ & $-6 \%$ & $-7 \%$ \\
\hline $\begin{array}{l}\text { Variability in Daily } \\
\text { Flows }\end{array}$ & 72.0 & 72.4 & 69.1 & 69.2 & 60.7 & 60.5 & $1 \%$ & $0 \%$ & $0 \%$ & $19 \%$ & $20 \%$ & $14 \%$ & $14 \%$ \\
\hline $\begin{array}{l}\text { Variability across } \\
\text { Minimum Monthly } \\
\text { Flows }\end{array}$ & 62.9 & 62.5 & 59.7 & 59.0 & 52.2 & 51.1 & $-1 \%$ & $-1 \%$ & $-2 \%$ & $20 \%$ & $22 \%$ & $14 \%$ & $15 \%$ \\
\hline $\begin{array}{l}\text { Variability across } \\
\text { Maximum Monthly } \\
\text { Flows }\end{array}$ & 71.5 & 73.5 & 68.7 & 70.3 & 60.2 & 61.7 & $3 \%$ & $2 \%$ & $2 \%$ & $19 \%$ & $19 \%$ & $14 \%$ & $14 \%$ \\
\hline Low Flood Pulse Count & 6 & 6 & 5 & 5 & 5 & 5 & 0.8 & 0.0 & -0.1 & 0.2 & 1.0 & -0.1 & 0.0 \\
\hline $\begin{array}{l}\text { Variability in Low Flood } \\
\text { Pulse Count }\end{array}$ & 39 & 34 & 47 & 43 & 45 & 43 & -4.6 & -3.9 & -2.2 & -6.2 & -8.6 & 1.5 & -0.2 \\
\hline High Flood Pulse Count & 9 & 9 & 9 & 9 & 10 & 10 & -0.3 & -0.1 & -0.6 & -1.3 & -1.0 & -0.9 & -0.4 \\
\hline $\begin{array}{l}\text { Variability in High Flood } \\
\text { Pulse Count }\end{array}$ & 32 & 31 & 31 & 34 & 34 & 35 & -1.3 & 3.0 & 1.8 & -1.2 & -4.2 & -2.3 & -1.0 \\
\hline $\begin{array}{l}\text { Annual minimum of 7- } \\
\text { day means of daily } \\
\text { discharge }\end{array}$ & 3.6 & 3.4 & 3.9 & 3.7 & 4.3 & 4.1 & $0 \%$ & $0 \%$ & $-4 \%$ & $-16 \%$ & $-17 \%$ & $-11 \%$ & $-12 \%$ \\
\hline $\begin{array}{l}\text { Annual maximum of 7- } \\
\text { day means of daily } \\
\text { discharge }\end{array}$ & 57.6 & 52.8 & 56.1 & 51.2 & 49.6 & 45.1 & $-8 \%$ & $-9 \%$ & $-9 \%$ & $16 \%$ & $17 \%$ & $13 \%$ & $14 \%$ \\
\hline $\begin{array}{l}\text { Julian date of annual } \\
\text { minimum }\end{array}$ & 252 & 260 & 256 & 258 & 255 & 260 & 7.5 & 2.8 & 4.7 & -2.8 & -0.1 & 0.4 & -1.5 \\
\hline $\begin{array}{l}\text { Variability in Julian date } \\
\text { of annual minimum }\end{array}$ & 24 & 20 & 23 & 22 & 21 & 21 & -4.3 & -0.9 & -0.4 & 3.2 & -0.7 & 1.9 & 1.5 \\
\hline $\begin{array}{l}\text { Julian date of annual } \\
\text { maximum }\end{array}$ & 0 & 365 & 364 & 363 & 0 & 0 & 364.8 & -1.1 & 0.2 & -0.2 & 364.4 & 364.1 & 362.8 \\
\hline $\begin{array}{l}\text { Variability in Julian date } \\
\text { of annual maximum }\end{array}$ & 33 & 33 & 33 & 33 & 38 & 41 & -0.3 & -0.5 & 3.2 & -4.8 & -8.3 & -5.0 & -8.7 \\
\hline
\end{tabular}




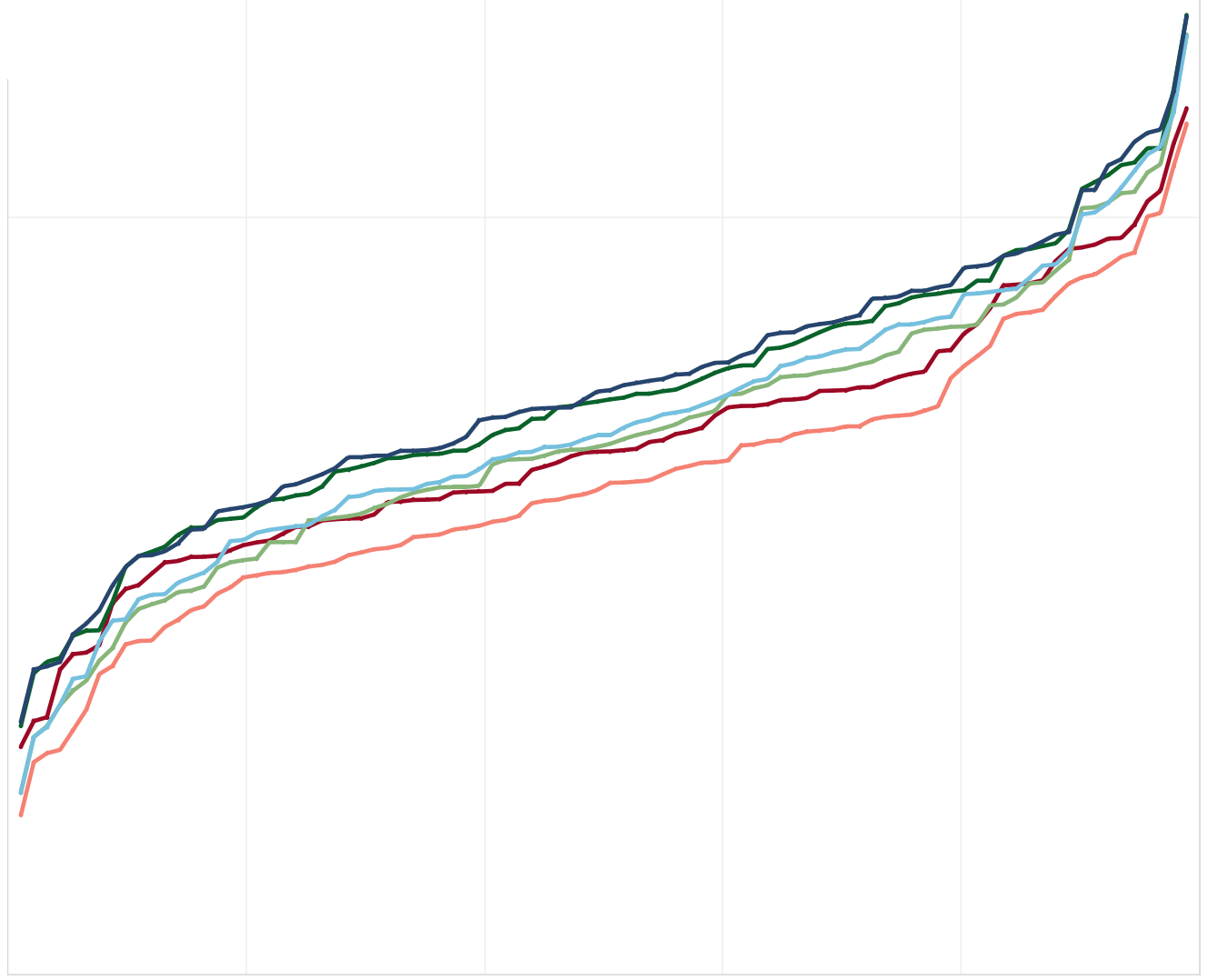

Figure I - 15: Annual daily flood cumulative density function for the North Fork of the Snoqualmie River for current managed forest (LC2007) and hypothetical unmanaged forest (LC2007M) under current (historical) and future (A1B, B1) climate conditions. 


\section{I.4.4.4 Snohomish basin at Monroe}

The overall effect of land use and climate change at the Snohomish Basin scale can be summarized as shown in Figure I - 14. The areas contributing most to the flow are in snowmelt and rain-snow transition areas, which in turn are mostly highly affected by climate change. Climate change is projected to affect the basin with more rain rather than snow, increasing the fall flow peak, and decreasing the snowmelt peak with an earlier snowmelt. The mean annual flow will not be affected. If no forest management were to occur in the basin, a lower mean annual flow (-10\%) and a slightly lower 7-day minimum flow (-4\%) would occur (Table I - 14).

Annual daily floods (Figure I - 15) are projected to increase for all return periods. Forest management practices contribute to an increase in the annual daily flood across the spectrum of return periods. 
Scenario

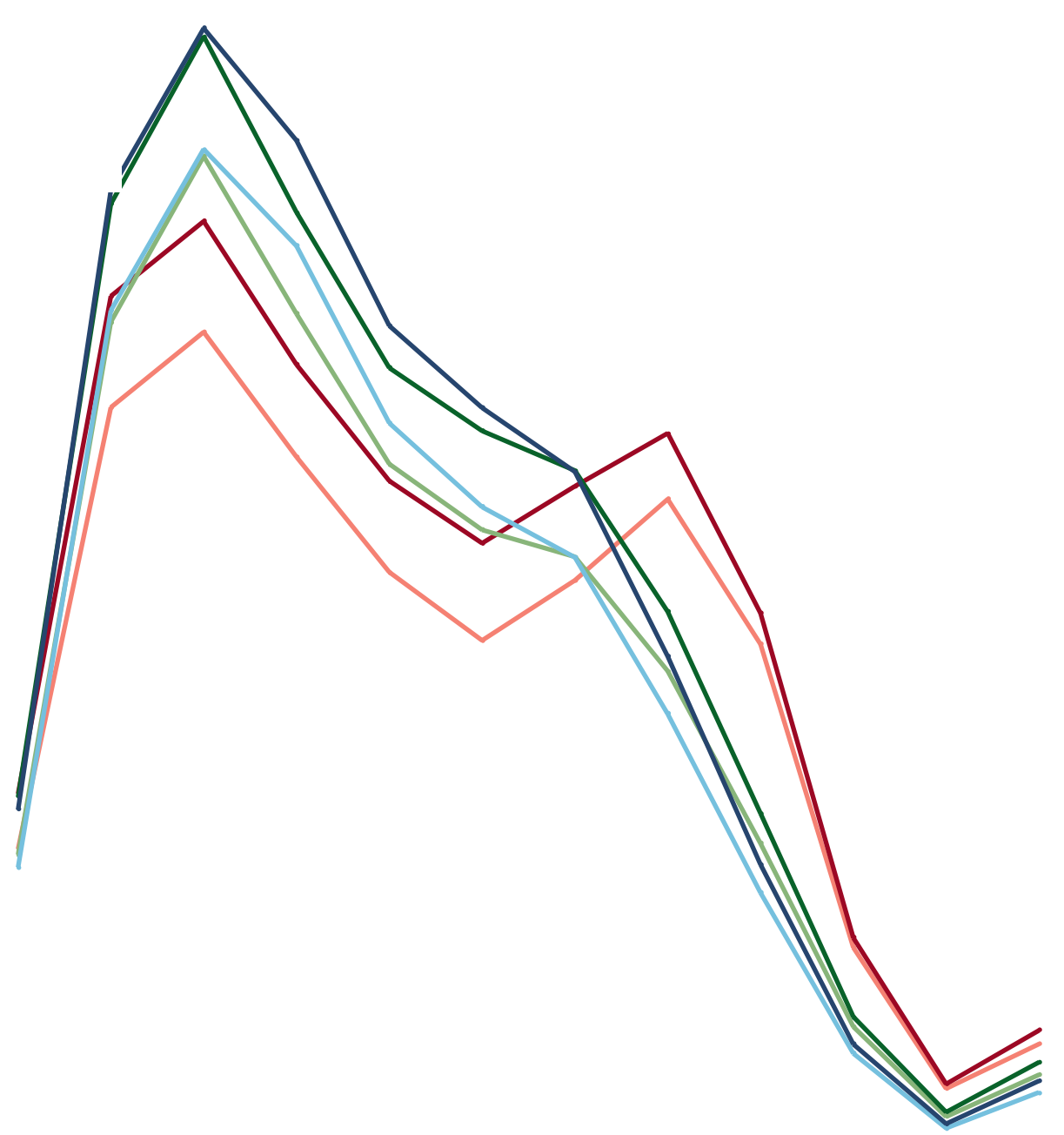

Figure I - 16: Monthly flow hydrograph at Monroe under current managed forest (LC2007) and hypothetical unmanaged forest (LC2007M) under current (historical) and future (A1B, B1) climate conditions. 
Table I - 14: HIT metrics at Monroe

\begin{tabular}{|c|c|c|c|c|c|c|c|c|c|c|c|c|c|}
\hline Climate Scenario & A1B & A1B & $\mathrm{B} 1$ & B1 & Hist. & Hist. & \multicolumn{3}{|c|}{ Land Cover Effect } & \multicolumn{4}{|c|}{ Climate Change Effect } \\
\hline Land Cover Scenario & $\begin{array}{l}\hat{\delta} \\
\text { N } \\
\text { U }\end{array}$ & 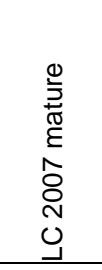 & $\begin{array}{l}\hat{0} \\
\text { N } \\
0 \\
\end{array}$ & 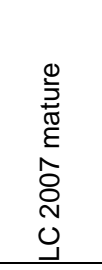 & $\begin{array}{l}\hat{\circ} \\
\text { O } \\
0 \\
\end{array}$ & 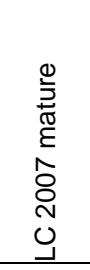 & $\begin{array}{l}2 \\
0 \\
0 \\
0 \\
\infty \\
0 \\
0 \\
0 \\
1 \\
1 \\
\frac{1}{\varepsilon}\end{array}$ & $\begin{array}{l}\sum \\
\text { D } \\
0 \\
\infty \\
\infty \\
0 \\
0 \\
\\
\overline{0}\end{array}$ & $\begin{array}{l}\sum \\
0 \\
0 \\
0 \\
\infty \\
0 \\
0 \\
0 \\
1 \\
1 \\
.00 \\
\end{array}$ & 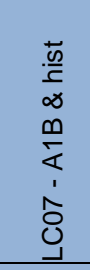 & 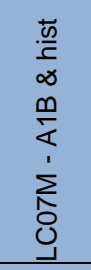 & $\begin{array}{l}\frac{\bar{w}}{\underline{\Gamma}} \\
\infty \\
\bar{\infty} \\
1 \\
\hat{0} \\
0\end{array}$ & 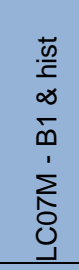 \\
\hline Mean Daily Flow & 302.9 & 270.9 & 303.3 & 271.4 & 297.4 & 266.2 & $-11 \%$ & $-11 \%$ & $-10 \%$ & $2 \%$ & $2 \%$ & $2 \%$ & $2 \%$ \\
\hline Median Daily Flow & 238 & 209 & 244 & 215 & 254 & 225 & $-12 \%$ & $-12 \%$ & $-11 \%$ & $-6 \%$ & $-7 \%$ & $-4 \%$ & $-4 \%$ \\
\hline Variability in Daily Flows & 84.5 & 85.2 & 81.1 & 81.5 & 71.9 & 71.8 & $1 \%$ & $0 \%$ & $0 \%$ & $18 \%$ & $19 \%$ & $13 \%$ & $14 \%$ \\
\hline $\begin{array}{l}\text { Variability across } \\
\text { Minimum Monthly Flows }\end{array}$ & 72.8 & 71.6 & 69.5 & 68.2 & 63.0 & 62.3 & $-2 \%$ & $-2 \%$ & $-1 \%$ & $16 \%$ & $15 \%$ & $10 \%$ & $10 \%$ \\
\hline $\begin{array}{l}\text { Variability across } \\
\text { Maximum Monthly Flows }\end{array}$ & 78.4 & 81.4 & 75.0 & 77.8 & 65.8 & 67.7 & $4 \%$ & $4 \%$ & $3 \%$ & $19 \%$ & $20 \%$ & $14 \%$ & $15 \%$ \\
\hline Low Flood Pulse Count & 2 & 2 & 3 & 3 & 3 & 3 & -0.1 & 0.0 & 0.1 & -0.9 & -1.1 & -0.8 & -0.9 \\
\hline $\begin{array}{l}\text { Variability in Low Flood } \\
\text { Pulse Count }\end{array}$ & 42 & 42 & 44 & 41 & 50 & 48 & 0.0 & -3.2 & -2.0 & -7.7 & -5.7 & -6.3 & -7.5 \\
\hline High Flood Pulse Count & 8 & 7 & 8 & 7 & 9 & 8 & -0.5 & -0.5 & -0.5 & -1.2 & -1.2 & -0.9 & -0.9 \\
\hline $\begin{array}{l}\text { Variability in High Flood } \\
\text { Pulse Count }\end{array}$ & 31 & 29 & 29 & 30 & 32 & 35 & -2.0 & 0.9 & 3.4 & -0.5 & -5.9 & -2.1 & -4.6 \\
\hline $\begin{array}{l}\text { Annual minimum of } 7- \\
\text { day means of daily } \\
\text { discharge }\end{array}$ & 31.3 & 30.0 & 34.2 & 32.8 & 40.4 & 39.0 & $-4 \%$ & $-4 \%$ & $-3 \%$ & $-22 \%$ & $-23 \%$ & $-15 \%$ & $-16 \%$ \\
\hline $\begin{array}{l}\text { Annual maximum of 7- } \\
\text { day means of daily } \\
\text { discharge }\end{array}$ & 1127.8 & 1037.1 & 1094.7 & 1004.9 & 965.5 & 879.7 & $-8 \%$ & $-8 \%$ & $-9 \%$ & $17 \%$ & $18 \%$ & $13 \%$ & $14 \%$ \\
\hline $\begin{array}{l}\text { Julian date of annual } \\
\text { minimum }\end{array}$ & 254 & 255 & 254 & 254 & 255 & 255 & 0.8 & 0.4 & 0.4 & -1.0 & -0.6 & -1.1 & -1.1 \\
\hline $\begin{array}{l}\text { Variability in Julian date } \\
\text { of annual minimum }\end{array}$ & 19 & 18 & 19 & 18 & 19 & 18 & -0.9 & -0.7 & -0.3 & 0.6 & 0.1 & 0.6 & 0.2 \\
\hline $\begin{array}{l}\text { Julian date of annual } \\
\text { maximum }\end{array}$ & 365 & 365 & 362 & 363 & 361 & 363 & -0.1 & 0.7 & 2.0 & 4.6 & 2.5 & 1.5 & 0.3 \\
\hline $\begin{array}{l}\text { Variability in Julian date } \\
\text { of annual maximum }\end{array}$ & 37 & 37 & 38 & 38 & 45 & 47 & -0.1 & 0.8 & 2.1 & -8.6 & -10.7 & -7.9 & -9.1 \\
\hline
\end{tabular}




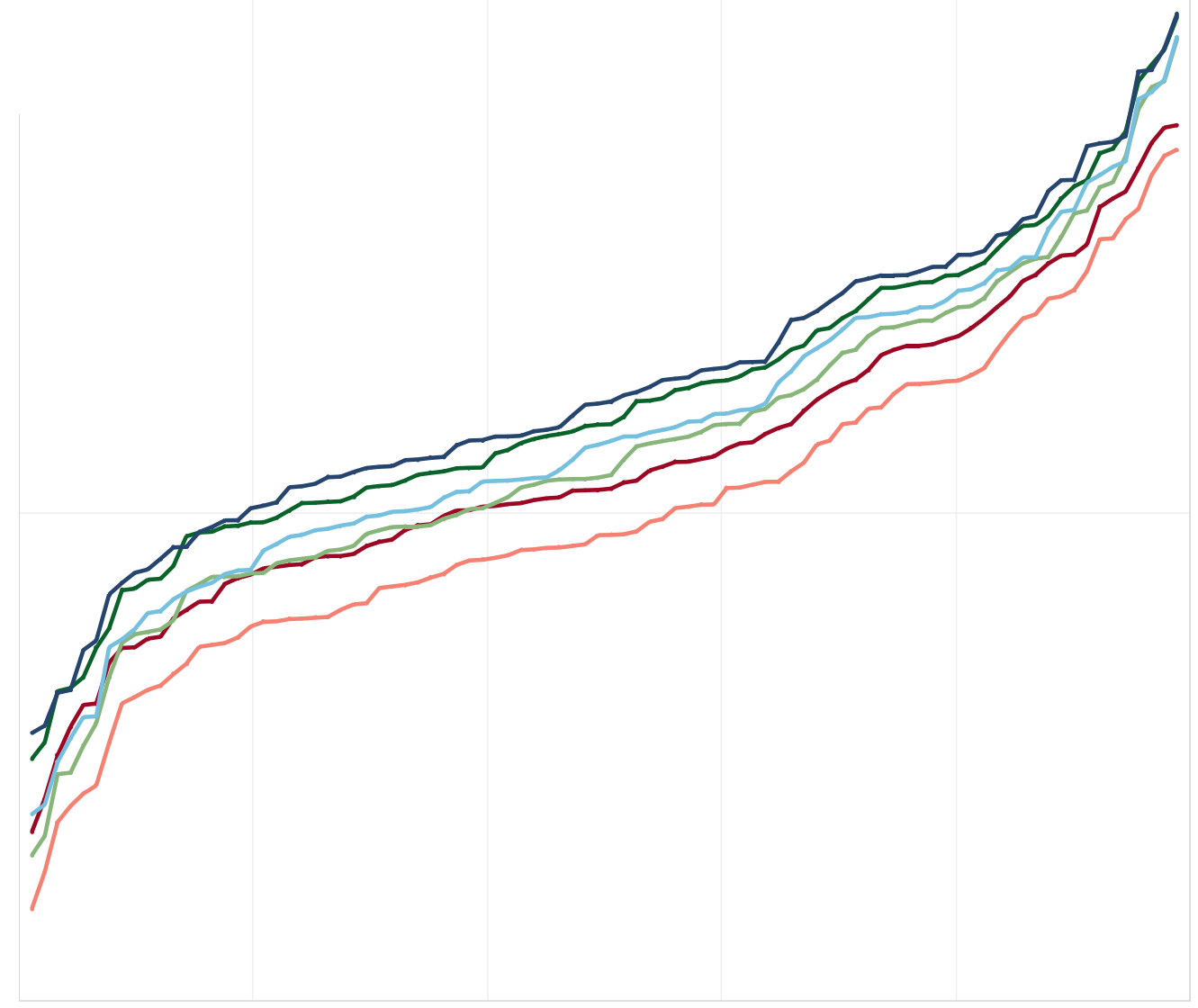

Figure I - 17: Annual daily flood cumulative density function at Monroe for current managed forest (LC2007) and hypothetical unmanaged forest (LC2007M) under current (historical) and future (A1B, B1) climate conditions.

\section{I.4.5 Discussion - conclusion}

Table I - 15 summarizes findings on the effects of forest management on the flow characteristics of interest for habitat restoration. Table I - 16 summarizes the drivers of change for specific flow characteristics for small subbasins under different hydro-climatological conditions. Figure I - 18 and Figure I - 19 summarize the effects of land use and climate changes over long term mean monthly flows and annual daily flood respectively, on basins of different hydro-meteorological conditions. 

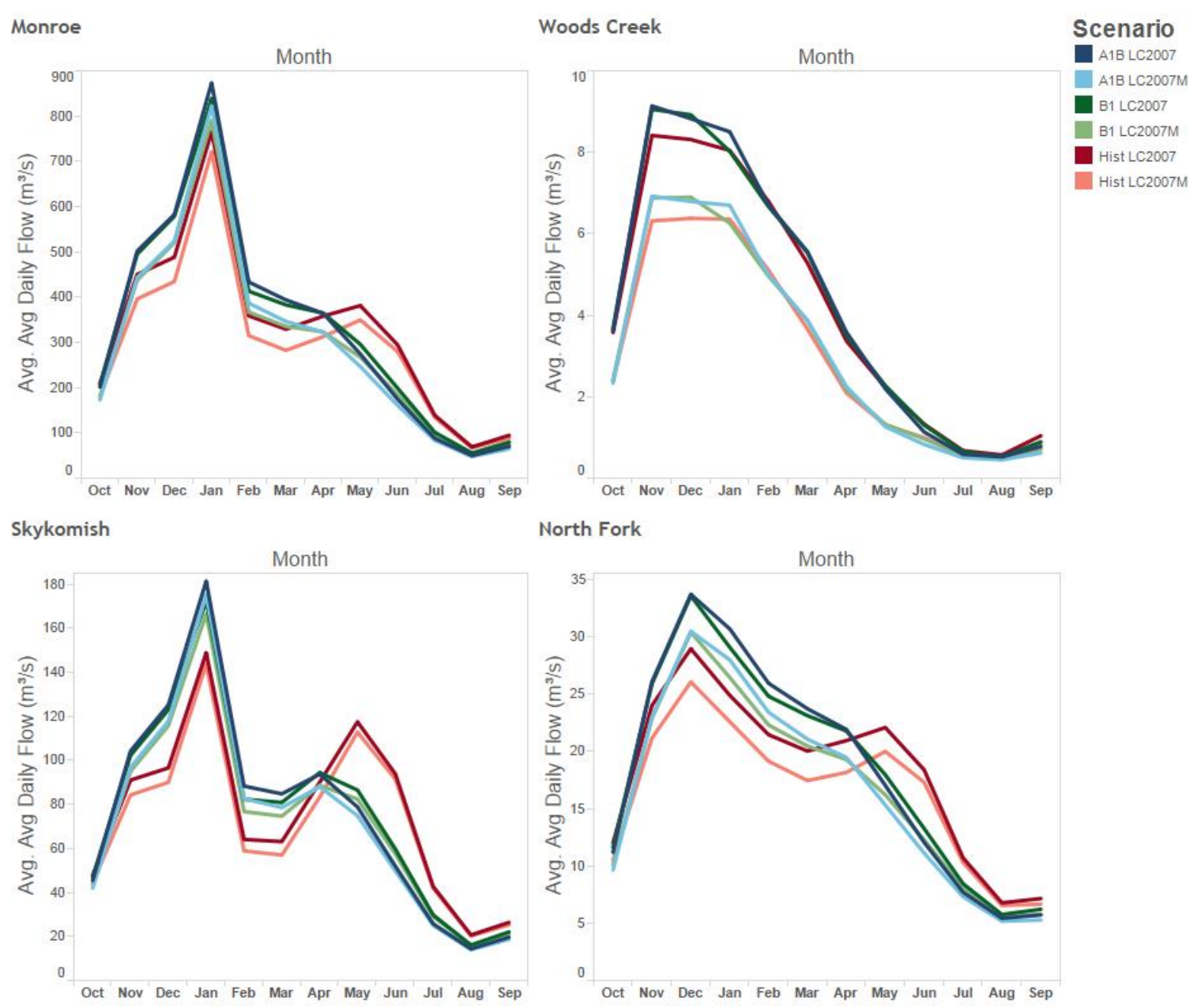

North Fork

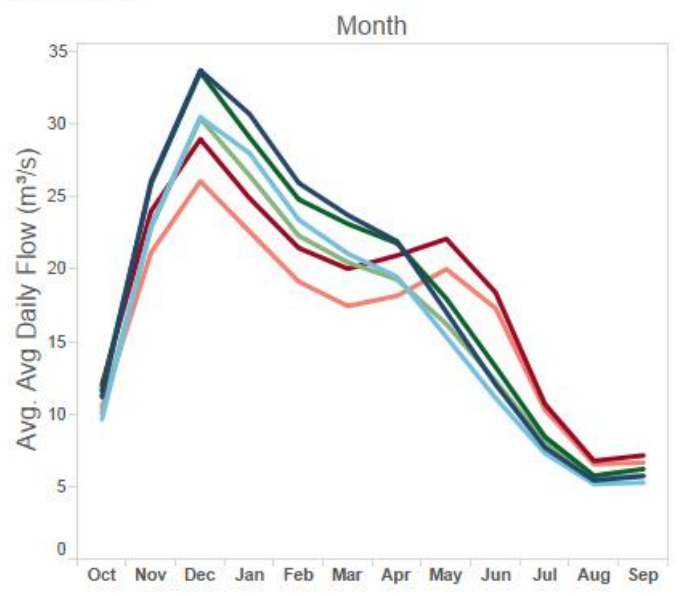

Figure I - 18: summary of the effect of forest management practices and predicted climate change on mean monthly flow over the 4 basins of interest.

\section{I.4.5.1 Effect of forest management}

Previous analyses performed in the Pacific Northwest region on the effect of forest management practices have found a range of effects. Van Shaar et al. (2002) analyzed the effect of forest harvesting over the Columbia River basin using DHSVM, and reported that forest harvesting "increased snow accumulation, increased stream flow, and reduced evapotranspiration, resulting in an increase of mean annual flows. They further found that streamflow changes were greatest during spring snowmelt runoff, and evapotranspiration decreases were greatest when soils are moister (spring/early summer). The results of this study show a higher mean annual flow under conditions of a managed forest (2007 land cover), which is in agreement with Van Shaar et al. This relationship can be explained as a mature forest has a higher leaf area index and (for this study) a higher canopy height, contributing to higher evapotranspiration losses. 
Our analyses indicate that forest harvesting increases the magnitude of the annual daily floods preferentially in rain-dominated subbasins for floods of all return periods, but only for short and medium return period for snowmelt and rain-snow transition subbasins. Beshta et al. (2000) reported no statistical significance for increases in flood-size peaks due to past and current forest management practices. However other results show that the size of the basin on which the analysis is performed affects the analysis. Green and Alila (2012) state that forest harvesting in snowy environments increases the magnitude and frequency of snowmelt floods; these floods not in agreement with changes in the annual daily flood from our study. Storm intensity and subbasin characteristics such as of aspect, gradient and elevation, affect the flood response. These analyses converge with ours and with those of Alila and Beckers (2001) and Bowling and Lettenmaier (1997) in terms of flooding, showing that forest harvest increases the magnitude of medium size floods but does not necessarily increase the magnitude of extreme floods. The extreme floods are controlled by the storm characteristics.

Table I - 15: Summary of the effects of forest management practices on specific flow characteristics over a series of hydro-climatological conditions

\begin{tabular}{|c|c|c|c|}
\hline Hydro-climatic conditions & $\begin{array}{l}\text { Rain } \\
\text { dominated }\end{array}$ & $\begin{array}{l}\text { Rain-snow } \\
\text { dominated }\end{array}$ & $\begin{array}{l}\text { Snowmelt } \\
\text { dominated }\end{array}$ \\
\hline Mean annual flow & $\begin{array}{l}\text { Increase } \\
(29 \%)\end{array}$ & $\begin{array}{l}\text { Increase } \\
(10 \%)\end{array}$ & $\begin{array}{l}\text { Increase } \\
(6 \%)\end{array}$ \\
\hline Daily flow variability & $\begin{array}{l}\text { Increase } \\
(-17 \%)\end{array}$ & None & None \\
\hline Extreme annual daily flood & Increase & None & None \\
\hline Low annual daily flood & Increase & Increase & Increase \\
\hline 7-day minimum flow & $\mathrm{N} / \mathrm{A}$ & None & $\begin{array}{l}\text { Slight increase } \\
(3 \%)\end{array}$ \\
\hline $\begin{array}{l}\text { Snowmelt timing (monthly } \\
\text { time scale) }\end{array}$ & $\mathrm{N} / \mathrm{A}$ & None & None \\
\hline
\end{tabular}

\section{I.4.5.2 Forest management and climate change}

Snowmelt control basins are more sensitive to the projected change in climate than to current forest practices (Figure I - 18). Current forest management has more effects on flow over rain dominated basins. However rain-snow transition basins are projected to be most impacted by the change in climate in particular with a transition to a more rain dominated regime (Figure I - 18). Therefore, there are future opportunities and challenges to come in order to mitigate impact of climate change with forest management practices or simply mitigate increased forest management sensitivity due to climate change in the future. The opportunities lay:

Mitigation of forest management under current conditions 
Mitigation of climate change effect on the mean annual flow, which impacts Summer flow, daily flow variability and extreme annual daily floods, possibly with forest management practices in current and future rain dominated basins.

Focus forest management in current snowmelt dominated basins that are predicted to keep this regime under future climate

Table I - 16: Summary of dominant drivers of change for specific flow characteristics for different hydro-climatological conditions

\begin{tabular}{|c|c|c|c|}
\hline $\begin{array}{l}\text { Hydro-climatic } \\
\text { conditions }\end{array}$ & Rain dominated & $\begin{array}{l}\text { Rain-snow } \\
\text { dominated }\end{array}$ & $\begin{array}{l}\text { Snowmelt } \\
\text { dominated }\end{array}$ \\
\hline $\begin{array}{l}\text { Mean annual } \\
\text { flow }\end{array}$ & $\begin{array}{l}\text { Forest } \\
\text { Management } \\
(29 \%)\end{array}$ & $\begin{array}{l}\text { Forest } \\
\text { Management } \\
(10 \%)\end{array}$ & $\begin{array}{l}\text { Forest } \\
\text { Management } \\
(6 \%)\end{array}$ \\
\hline $\begin{array}{l}\text { Daily flow } \\
\text { variability }\end{array}$ & $\begin{array}{l}\text { Forest } \\
\text { Management } \\
(-17 \%)\end{array}$ & $\begin{array}{l}\text { Climate Change } \\
(14 \text { to } 20 \%)\end{array}$ & $\begin{array}{l}\text { Climate Change } \\
\text { (8 to } 14 \% \text { ) }\end{array}$ \\
\hline $\begin{array}{l}\text { Extreme annual } \\
\text { daily flood (low } \\
\text { return period) }\end{array}$ & $\begin{array}{l}\text { Forest } \\
\text { Management }+ \\
\text { Climate Change }\end{array}$ & Climate Change & Climate Change \\
\hline $\begin{array}{l}\text { Low annual } \\
\text { daily flood }\end{array}$ & $\mathrm{N} / \mathrm{A}$ & $\begin{array}{l}\text { Forest } \\
\text { Management }+ \\
\text { Climate Change }\end{array}$ & $\begin{array}{l}\text { Forest } \\
\text { Management + } \\
\text { Climate Change }\end{array}$ \\
\hline $\begin{array}{l}\text { 7-day minimum } \\
\text { flow }\end{array}$ & $\mathrm{N} / \mathrm{A}$ & $\begin{array}{l}\text { Climate Change } \\
(-11 \text { to }-17 \%)\end{array}$ & $\begin{array}{l}\text { Climate Change } \\
(-18 \text { to }-26 \%)\end{array}$ \\
\hline $\begin{array}{l}\text { Snowmelt } \\
\text { timing (monthly } \\
\text { time scale) }\end{array}$ & $\mathrm{N} / \mathrm{A}$ & Climate Change & Climate Change \\
\hline
\end{tabular}




\section{I.5 References:}

Alberti M, Weeks R, Coe S. 2004. Urban land-cover change analysis in central Puget Sound. Engineering and Remote Sensing 70: 1043-1052.

Alila, Y. and Beckers, J., 2001: Using numerical modelling to address hydrologic forest management issues in British Columbia, Hydrol. Process. 15, 3371-3387

Beschta, R., Pyles, M., Skaugset, A., and Surfleet, C. (2000). Peakflow responses to forest practices in the western Cascades of Oregon, USA. Journal of Hydrology, 233:102-120.

Bowling, L. and Lettenmaier, D. (1997). Evaluation of the Effects of Forest Roads on Streamflow in Hard and Ware Creeks, Washington. Technical Report Water Resources Series No. 155, Dept. of Civil Engineering, University of Washington, Seattle, Washington.

Bowling, L.C., P. Storck and D.P. Lettenmaier, 2000: Hydrologic effects of logging in Western Washington, United States, Wat. Resour. Res., 36, 3223-3240.

Bras, R. (1990). Hydrology, An Introduction to Hydrologic Science. Addison-Wesley, Reading, MA Cuo, L., Beyene, T. K., Voisin, N., Su, F., Lettenmaier, D. P., Alberti, M. and Richey, J. E. 2011, Effects of mid-twenty-first century climate and land cover change on the hydrology of the Puget Sound basin, Washington. Hydrol. Process., 25: 1729-1753. doi: 10.1002/hyp.7932

Cuo, L., D.P. Lettenmaier D.P., M. Alberti, and J.E. Richey, 2009: Effects of a century of land cover and climate change on the hydrology of Puget Sound basin, Hydrological Processes, 23, 907-933.

Cuo, L, D.P. Lettenmaier, B. V. Mattheussen, P.Storck and M. Wiley, 2008: Hydrological prediction for urban watersheds with the Distributed Hydrology-Soil-Vegetation Model , Hydrological Processes vol. 22(21) 4205-4213 DOI: 10.1002/hyp.7023.

Doten, C.O., L.C. Bowling, E.P. Maurer, J.S. Lanini, and D.P. Lettenmaier, 2006: A spatially distributed model for the dynamic prediction of sediment erosion and transport in mountainous forested watersheds, Water Resour. Res., Vol. 42, No. 4, W0441710.1029/2004WR003829

Elsner, M.M., L. Cuo, N. Voisin, J.S. Deems, A.F. Hamlet, J.A. Vano, K.E.B. Mickelson, S.Y. Lee, and D.P. Lettenmaier, 2010: Implications of 21st Century climate change for the hydrology of Washington State, Climatic Change, Vol. 102, Issue 1-2, 225-260, doi:10.1007/s10584-010-9855-0

Green, K. C. and Y. Alila (2012), A paradigm shift in understanding and quantifying the effects of forest harvesting on floods in snow environments, Water Resour. Res., doi:10.1029/2012WR012449, in press Hamlet A.F.,Lettenmaier D.P., 2005: Production of temporally consistent gridded precipitation and temperature fields for the continental U.S., J. of Hydrometeorology, 6 (3): 330-336

Khangaonkar T, and Z Yang. 2011. "A High Resolution Hydrodynamic Model of Puget Sound to Support Nearshore Restoration Feasibility Analysis and Design." Ecological Restoration 29(1-2):173-184. doi:10.3368/er.29.1-2.173 
Kimball, J. S., S. W. Running, and R. R. Nemani, 1997: An improved method for estimating surface humidity from daily minimum temperature, Agr. Forest Meteorol., 85, 87-98.

Liang, X., D. P. Lettenmaier, E. F. Wood, and S. J. Burges, 1994: A Simple hydrologically Based Model of Land Surface Water and Energy Fluxes for GSMs, J. Geophys. Res., 99(D7), 14,415-14,428.

Maurer, E.P., A.W. Wood, J.C. Adam, D.P. Lettenmaier, and B. Nijssen, 2002, A long-term hydrologically-based data set of land surface fluxes and states for the conterminous United States, J. Climate. 15, 3237-3251.

Mishra, V., Cherkauer, K.A., Niyogi, D., Lei, M., Pijanowski, B.C., Ray, D.K., Bowling, L.C. and Yang, G., 2010c. A regional scale assessment of land use/land cover and climatic changes on water and energy cycle in the upper Midwest United States. International Journal of Climatology [Tier 2], 30(13): 20252044.

National Oceanic and Atmospheric Administration (2013, August 7). Climate change threatens U.S. estuaries. ScienceDaily. Retrieved October 4, 2013, from http://www.sciencedaily.com/releases/2013/08/130807130056.htm

Schnorbus, M., and Y. Alila (2004), Forest harvesting impacts on the peak flow regime in the Columbia Mountains of southeastern British Columbia: An investigation using long-term numerical modeling, Water Resour. Res., 40, W05205, doi:10.1029/2003WR002918.

Storck, P., L. Bowling, P. Wetherbee and D. Lettenmaier, 1998: Application of a GIS-based distributed hydrology model for prediction of forest harvest effects on peak stream flow in the Pacific Northwest, Hydrol. Process., 12, 889-904.

Thanapakpawin, P (2007) Spatially-Distributed Modeling of Hydrology and Nitrogen Export from Watersheds. Ph.D. thesis, University of Washington, Seattle, WA.

Thornton, P. E., and S. W. Running, 1999: An improved algorithm for estimating incident daily solar radiation from measurements of temperature, humidity, and precipitation, Agr. Forest Meteorol., 93, 211228.

Vano, J.A., N. Voisin, L. Cuo, A.F. Hamlet, M.M. Elsner, R.N. Palmer, A. Polebitski, and D.P. Lettenmaier, 2010: Climate change impacts on water management in the Puget Sound region, Washington, USA, Climatic Change, Vol. 102, Issue 1-2, 225-260, doi:10.1007/s10584-010-9846-1

VanShaar, J.R., I. Haddeland, and D.P. Lettenmaier, 2002: Effects of land cover changes on the hydrologic response of interior Columbia River Basin forested catchments, Hydrol. Process., 16, 24992520.

Westerink, J.J., R.A. Luettich, A.M. Baptista, N.W. Scheffner and P. Farrar, “Tide and Storm Surge Predictions Using a Finite Element Model,” Journal of Hydraulic Engineering, 118, 1373-1390, 1992. Whitaker, A., Alila, Y., Beckers, J., and Toews, D., 2002: Evaluating peak flow sensitivity to clearcutting in different elevation bands of a snowmelt-dominated mountainous catchment, Water Resour. Res. 38(9), 1172, doi: 10.1029/2001WR000514.

Wigmosta, M.S., L. Vail, and D. P. Lettenmaier, 1994: A distributed hydrology-vegetation model for complex terrain, Wat. Resour. Res., 30, 1665-1679. 
Wigmosta MS, B Nijssen, and P Storck. 2002. "The Distributed Hydrology Soil Vegetation Model." Chapter 2 in Mathematical Models of Small Watershed Hydrology and Applications, vol. ., ed. VP Singh \& DK Frevert, pp. 7-42. Water Resources Publications, Highlands Ranch, CO.

Wiley, M. (2006). Implementation and Validation of a Distributed Hydrologic Model as a Component of the Integrated Assessment of Water Quality in Hood Canal, Washington. Ph.D. thesis, University of Washington, Seattle, WA. 


\section{I.6 Supplemental information on subbasin responses}

Table I - 17. Skykomish (USGS gage 12133000) - LC2002 vs. LC2050

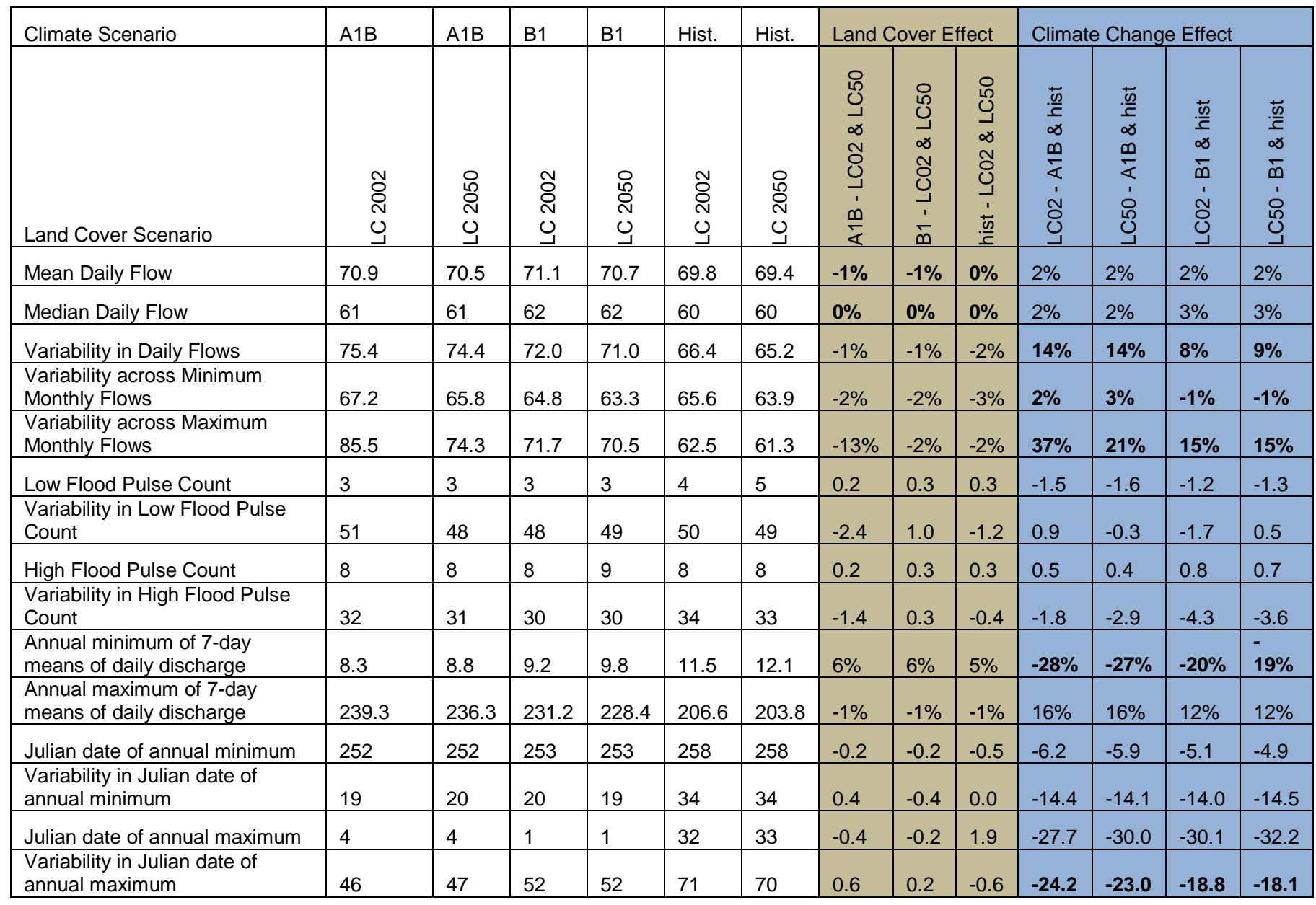


Table I - 18. West Woods Creek - LC2002 vs. LC2050

\begin{tabular}{|c|c|c|c|c|c|c|c|c|c|c|c|c|c|}
\hline \multirow{2}{*}{$\begin{array}{l}\text { Climate Scenario } \\
\text { Land Cover Scenario }\end{array}$} & \multirow{2}{*}{$\begin{array}{l}\mathrm{A} 1 \mathrm{~B} \\
\end{array}$} & \multirow{2}{*}{$\begin{array}{l}\text { A1B } \\
\\
\text { O } \\
\text { N } \\
\text { U્J }\end{array}$} & \multirow{2}{*}{ 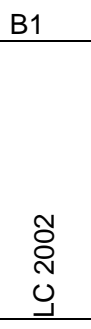 } & \multirow{2}{*}{$\begin{array}{l}\text { B1 } \\
\\
\text { O } \\
\text { O } \\
\text { U્ય }\end{array}$} & \multirow{2}{*}{ 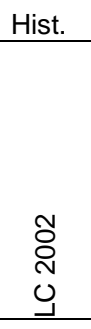 } & \multirow{2}{*}{$\begin{array}{l}\text { Hist. } \\
\\
\\
\\
\text { O } \\
\text { N } \\
0 \\
\end{array}$} & \multicolumn{3}{|c|}{ Land Cover Effect } & \multicolumn{4}{|c|}{ Climate Change Effect } \\
\hline & & & & & & & 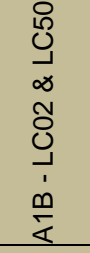 & 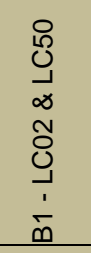 & 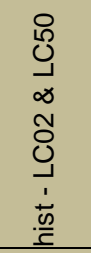 & 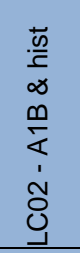 & 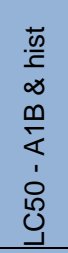 & 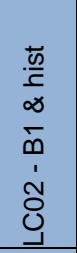 & 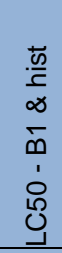 \\
\hline Mean Daily Flow & 3.6 & 4.3 & 3.6 & 4.3 & 3.5 & 4.1 & $19 \%$ & $19 \%$ & $19 \%$ & $3 \%$ & $3 \%$ & $3 \%$ & $3 \%$ \\
\hline Median Daily Flow & 1 & 2 & 1 & 2 & 1 & 2 & $\mathrm{~N} / \mathrm{A}$ & $\mathrm{N} / \mathrm{A}$ & $\mathrm{N} / \mathrm{A}$ & $\mathrm{N} / \mathrm{A}$ & $\mathrm{N} / \mathrm{A}$ & $\mathrm{N} / \mathrm{A}$ & $\mathrm{N} / \mathrm{A}$ \\
\hline Variability in Daily Flows & 159.0 & 138.2 & 157.2 & 136.3 & 156.7 & 136.2 & $-13 \%$ & $-13 \%$ & $-13 \%$ & $1 \%$ & $1 \%$ & $0 \%$ & $0 \%$ \\
\hline $\begin{array}{l}\text { Variability across Minimum } \\
\text { Monthly Flows }\end{array}$ & 350.2 & 251.6 & 354.9 & 251.0 & 354.7 & 262.9 & $-28 \%$ & $-29 \%$ & $-26 \%$ & $-1 \%$ & $-4 \%$ & $0 \%$ & $-5 \%$ \\
\hline $\begin{array}{l}\text { Variability across Maximum } \\
\text { Monthly Flows }\end{array}$ & 92.4 & 82.0 & 89.9 & 80.0 & 88.7 & 78.3 & $-11 \%$ & $-11 \%$ & $-12 \%$ & $4 \%$ & $5 \%$ & $1 \%$ & $2 \%$ \\
\hline High Flood Pulse Count & 14 & 15 & 14 & 15 & 15 & 15 & 0.7 & 0.6 & 0.6 & -0.6 & -0.6 & -0.2 & -0.2 \\
\hline $\begin{array}{l}\text { Variability in High Flood Pulse } \\
\text { Count }\end{array}$ & 22 & 22 & 21 & 22 & 22 & 23 & 0.4 & 0.5 & 1.0 & 0.2 & -0.4 & -0.1 & -0.6 \\
\hline $\begin{array}{l}\text { Annual minimum of 7-day means } \\
\text { of daily discharge }\end{array}$ & 0.0 & 0.0 & 0.0 & 0.0 & 0.0 & 0.0 & $\mathrm{~N} / \mathrm{A}$ & $\mathrm{N} / \mathrm{A}$ & $\mathrm{N} / \mathrm{A}$ & $\mathrm{N} / \mathrm{A}$ & $\mathrm{N} / \mathrm{A}$ & $\mathrm{N} / \mathrm{A}$ & $\mathrm{N} / \mathrm{A}$ \\
\hline $\begin{array}{l}\text { Annual maximum of 7-day means } \\
\text { of daily discharge }\end{array}$ & 22.8 & 23.3 & 22.4 & 23.0 & 21.7 & 22.4 & $3 \%$ & $3 \%$ & $3 \%$ & $5 \%$ & $4 \%$ & $3 \%$ & $3 \%$ \\
\hline Julian date of annual minimum & 277 & 280 & 277 & 281 & 277 & 282 & 3.4 & 4.3 & 4.5 & -0.6 & -1.7 & -0.4 & -0.6 \\
\hline $\begin{array}{l}\text { Variability in Julian date of annual } \\
\text { minimum }\end{array}$ & 9 & 15 & 10 & 21 & 10 & 19 & 5.4 & 11.0 & 8.8 & -1.0 & -4.4 & -0.6 & 1.6 \\
\hline Julian date of annual maximum & 359 & 357 & 358 & 356 & 360 & 359 & -1.6 & -2.0 & -1.0 & -1.1 & -1.6 & -2.0 & -3.0 \\
\hline
\end{tabular}


Table I - 19. North Fork Snoqualmie - LC2002 vs. LC2050

\begin{tabular}{|c|c|c|c|c|c|c|c|c|c|c|c|c|c|}
\hline Climate Scenario & $\mathrm{A} 1 \mathrm{~B}$ & $\mathrm{~A} 1 \mathrm{~B}$ & $\mathrm{~B} 1$ & B1 & Hist. & Hist. & Land $\mathrm{C}$ & over Ef & ect & Climate & Change & Effect & \\
\hline Land Cover Scenario & $\begin{array}{l}\text { ণ } \\
\text { N } \\
0 \\
\end{array}$ & $\begin{array}{l}\circ \\
\stackrel{0}{0} \\
\text { N } \\
0\end{array}$ & $\begin{array}{l}\widetilde{O} \\
\stackrel{O}{0} \\
0 \\
\end{array}$ & $\begin{array}{l}\text { 옹 } \\
\text { N } \\
0 \\
\end{array}$ & 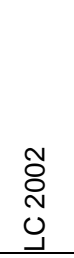 & $\begin{array}{l}\text { 오 } \\
\text { N } \\
ن\end{array}$ & 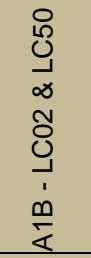 & 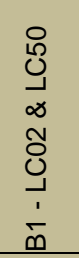 & 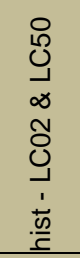 & 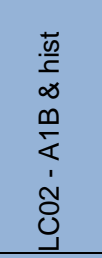 & 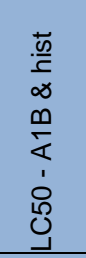 & 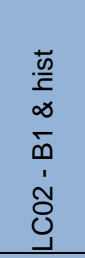 & 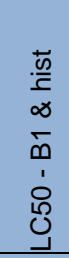 \\
\hline Median Daily Flow & 15 & 16 & 15 & 17 & 15 & 17 & $7 \%$ & $13 \%$ & $13 \%$ & $0 \%$ & $-6 \%$ & $0 \%$ & $0 \%$ \\
\hline Variability in Daily Flows & 71.0 & 68.8 & 67.8 & 66.0 & 59.2 & 58.3 & $-3 \%$ & $-3 \%$ & $-2 \%$ & $20 \%$ & $18 \%$ & $15 \%$ & $13 \%$ \\
\hline $\begin{array}{l}\text { Variability across Minimum Monthly } \\
\text { Flows }\end{array}$ & 60.8 & 59.5 & 57.7 & 56.7 & 50.4 & 49.7 & $-2 \%$ & $-2 \%$ & $-1 \%$ & $21 \%$ & $20 \%$ & $15 \%$ & $14 \%$ \\
\hline $\begin{array}{l}\text { Variability across Maximum Monthly } \\
\text { Flows }\end{array}$ & 71.0 & 67.2 & 68.1 & 64.3 & 59.4 & 57.1 & $-5 \%$ & $-6 \%$ & $-4 \%$ & $20 \%$ & $18 \%$ & $15 \%$ & $13 \%$ \\
\hline High Flood Pulse Count & 9 & 9 & 10 & 10 & 11 & 11 & 0.2 & 0.5 & 0.5 & -1.5 & -1.7 & -0.7 & -0.7 \\
\hline Variability in High Flood Pulse Count & 35 & 32 & 31 & 28 & 34 & 34 & -3.4 & -2.5 & 0.2 & 1.2 & -2.4 & -3.2 & -5.9 \\
\hline $\begin{array}{l}\text { Annual minimum of 7-day means of } \\
\text { daily discharge }\end{array}$ & 3.7 & 4.1 & 4.0 & 4.4 & 4.5 & 4.8 & $10 \%$ & $9 \%$ & $7 \%$ & $-18 \%$ & $-16 \%$ & $-12 \%$ & $10 \%$ \\
\hline $\begin{array}{l}\text { Annual maximum of } 7 \text {-day means of } \\
\text { daily discharge }\end{array}$ & 56.6 & 59.7 & 55.0 & 58.1 & 48.4 & 51.6 & $5 \%$ & $6 \%$ & $7 \%$ & $17 \%$ & $16 \%$ & $14 \%$ & $13 \%$ \\
\hline Julian date of annual minimum & 258 & 250 & 256 & 255 & 259 & 255 & -7.5 & -0.9 & -3.8 & -1.2 & -4.9 & -3.5 & -0.6 \\
\hline $\begin{array}{l}\text { Variability in Julian date of annual } \\
\text { minimum }\end{array}$ & 24 & 22 & 21 & 22 & 18 & 20 & -1.9 & 1.1 & 1.2 & 5.2 & 2.1 & 2.4 & 2.3 \\
\hline Julian date of annual maximum & 0 & 364 & 363 & 363 & 365 & 364 & 364.2 & -0.1 & -0.9 & -364.5 & 0.6 & -2.0 & -1.3 \\
\hline
\end{tabular}




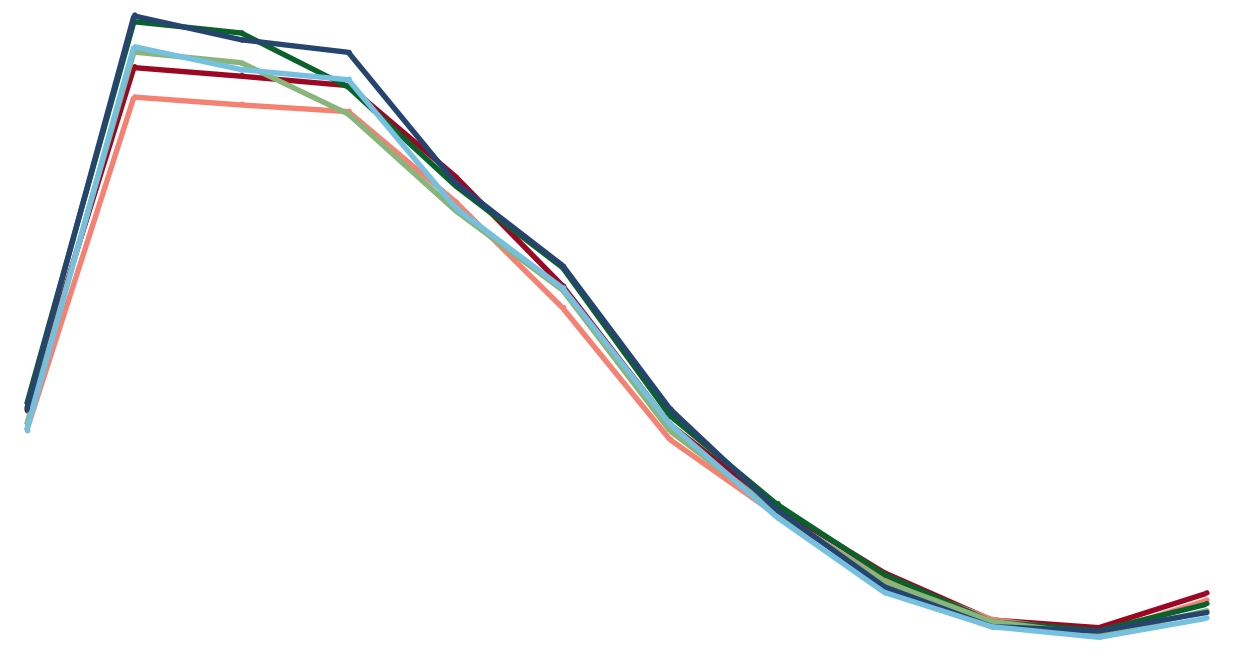

Figure I - 19: Woods Creek 


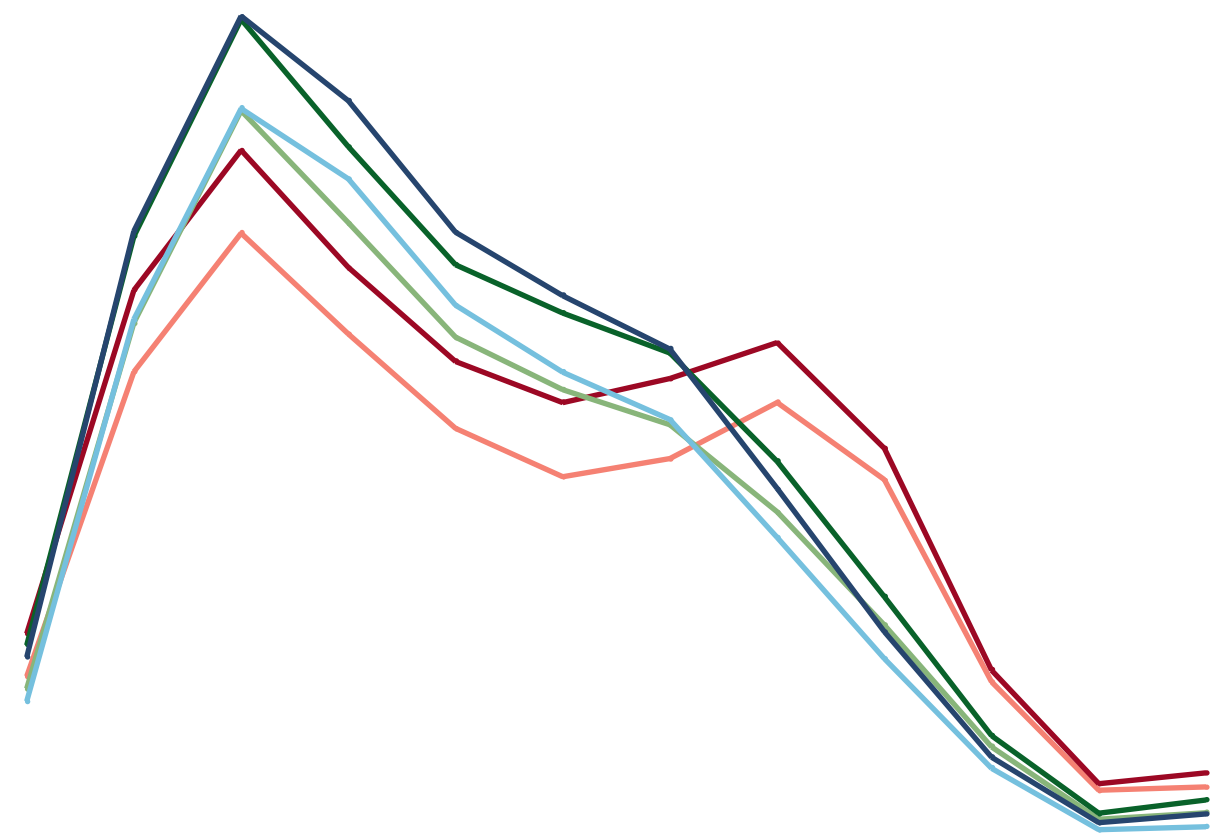

Figure I - 20: North Fork Snoqualmie 


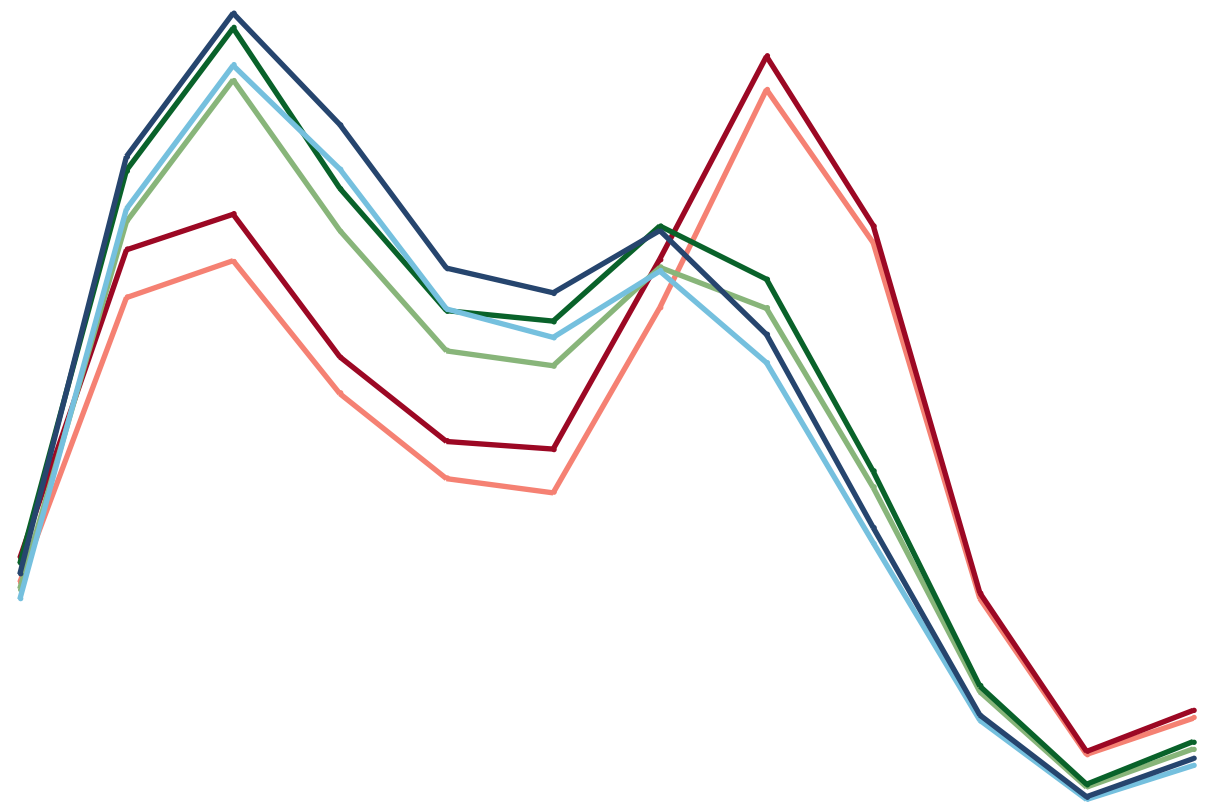

Figure I - 21: South Fork Skykomish 
Appendix II. Estuarine Hydrodynamic Responses to River Flow under Climate Change and Land Use Land Cover Scenarios

Z Yang, T Wang and N. Voisin 


\section{Contents}

Appendix II. Estuarine Hydrodynamic Responses to River Flow under Climate Change and Land Use

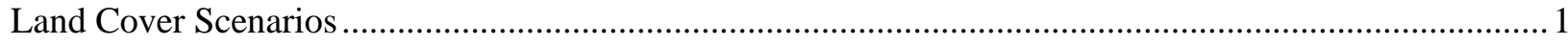

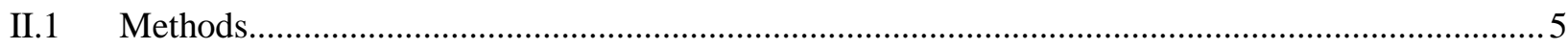

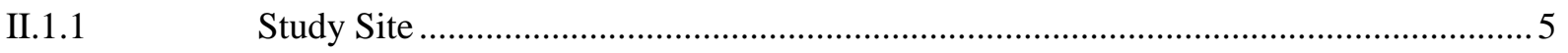

II.1.2 Hydrodynamic Model of Snohomish River Estuary ................................................ 8

II.1.3 Land Use Land Cover and Climate Change Scenarios ........................................... 10

II.1.4 Modeling Approach and Simulation Design......................................................... 14

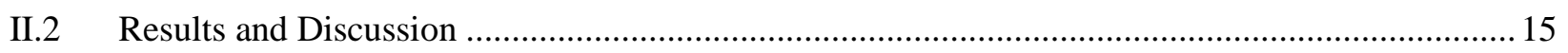

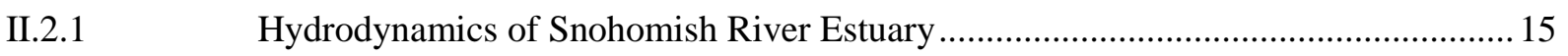

II.2.2 Salinity Intrusion in the Distributaries ............................................................. 18

II.2.3 Inundation in Intertidal Zone and River Floodplain.............................................20

II.2.4 Estuarine Response to Climate Change and LULC Scenarios....................................23

II.2.5 Estuarine Response to Sea-level Rise Scenarios ..................................................26

II.2.6 Simulation of Fecal Coliform Fate and Transport ................................................29

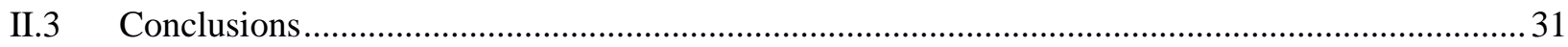

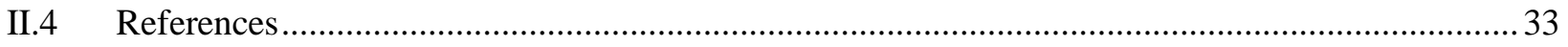




\section{Figures}

Figure II - 1. Snohomish River Estuary in Puget Sound, Washington, USA....................................

Figure II - 2. Distributary sloughs in the Lower Snohomish River Estuary …................................ 8

Figure II - 3. Model bathymetry (NAVD88) for the entire model domain (left) and the Lower

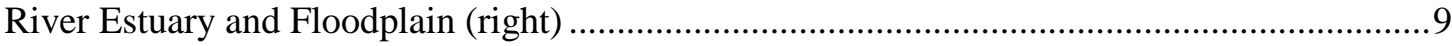

Figure II - 4. FVCOM unstructured-grid for the Lower Snohomish River Estuary ........................10

Figure II - 5. Comparisons of simulated river flows by DHSVM for different climate change and land use scenarios (AMM - Average Monthly Mean flow; LLM - Lowest flow of Lowest Monthly climatology; ALM - Average flow of Lowest Monthly climatology; HLM Highest flow of Lowest Monthly climatology; LHM - Lowest flow of Highest Monthly climatology; AHM - Average flow of Highest Monthly climatology; HHM - Highest flow of Highest Monthly climatology).

Figure II - 6. Water surface elevation at the river mouth of the Snohomish River Estuary relative to NAVD88 vertical datum.

Figure II - 7. Salinity time series at the mouths of Snohomish River main-stem, Steamboat Slough and Ebey Slough under average monthly mean flow condition $\left(270 \mathrm{~m}^{3} / \mathrm{s}\right)$.

Figure II - 8. Salinity difference (bottom - surface) at the river mouths of Snohomish River, Steamboat Slough and Ebey Slough under average monthly mean flow condition $\left(270 \mathrm{~m}^{3} / \mathrm{s}\right) 17$

Figure II - 9. surface salinity and velocity distributions in the Lower Snohomish River Estuary during flood (left) and ebb (right) tides

Figure II - 10 Salinity intrusion points in the Snohomish River distributaries as a function of river flow (Note: negative distance means the salinity intrusion point is downstream of the river mouth)

Figure II - 11. Comparison of salinity intrusion points in the distributaries of Snohomish River Estuary (Note: negative distance means the salinity intrusion point is downstream of the river mouth)

Figure II - 12 Floodplain (green color) in the lower Snohomish River Estuary defined by FEMA .21

Figure II - 13. Normalized inundated area in tidal wetland and floodplain of Snohomish River Estuary

Figure II - 14. Comparisons of inundated areas at low tide between river flow of $765 \mathrm{~m}^{3} / \mathrm{s}$ (left) and $810 \mathrm{~m}^{3} / \mathrm{s}$ (right) conditions

Figure II - 15. Average water depth of inundated area in tidal wetland and floodplain of Snohomish River Estuary

Figure II - 16. Average salinity of inundated area in tidal wetland and floodplain of Snohomish River Estuary

Figure II - 17. Salinity intrusion points in the distributaries of Snohomish River Estuary under climate change (A1B and B1) and LULC scenarios.

Figure II - 18. Normalized Inundated Area in the Snohomish River Estuary under climate change (A1B and B1) and LULC scenarios

Figure II - 19. Average water depth in the inundated area of Snohomish River Estuary under

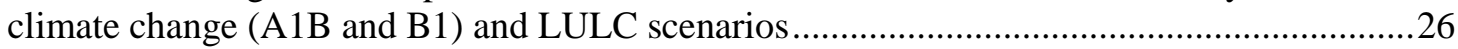

Figure II - 20. Average salinity in the inundated area of Snohomish River Estuary under climate change (A1B and B1) and LULC scenarios. 
Figure II - 21. Salinity intrusion points in the Snohomish River Estuary as a result of sea-level rise under historical lowest, average and highest monthly river flow conditions

Figure II - 22. Normalized inundation area in the Snohomish River Estuary as a result of sea-level rise under historical lowest, average and highest monthly river flow conditions

Figure II - 23. Average water depth of inundated area in the Snohomish River Estuary as a result of sea-level rise under historical lowest, average and highest monthly river flow conditions..28

Figure II - 24. Average salinity of inundated area in the Snohomish River Estuary as a result of sea-level rise under historical lowest, average and highest monthly river flow conditions......29

Figure II - 25. Surface concentration of fecal coliform in Port Gardner of Snohomish River

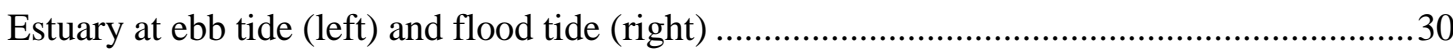

\section{Tables}

Table II - 1. Monthly Average Flows (m3/s) from DHSVM Simulations for LULC 2002 and LULC 2050 Scenarios under Historical Climate Condition (1915 - 2006).

Table II - 2. Monthly Average Flows (m3/s) from DHSVM Simulations for Future Climate Change A1B and B1 Emission Scenarios under LULC 2002 condition (2030-2050).

Table II - 3. Daily minimum and maximum flows (m3/s) from DHSVM simulations for historical conditions (1916 - 2006) and Climate Change A1B and B1 Scenarios (2030-2050) .13 


\section{Appendix II: Introduction}

Management of stormwater, coastal and river flooding, temperature and nutrient stress on salmon are management priorities within the watersheds and estuaries of Puget Sound. These management challenges depend on accurate estimates of the freshwater flow delivered from snowpack and precipitation. Accurate modeling of water flows regimes in the watersheds and estuaries, as well as water quality parameters will provide improved tools for stormwater management. It is important to better understand how the estuarine hydrodynamics respond to the change of freshwater flow in the watershed as a result of future climate change, land use and land cover scenarios, and sea-level rise.

This appendix provides a detailed description of the estuarine modeling component of the project - Integrated Modeling and Decision-Support System for Water Management in the Puget Sound Basin. Tidal circulation, mixing, and salinity intrusion in estuaries are complex processes because of geometry effects and multiple forcing mechanisms including tide, wind and river flows. Numerical modeling has been used widely to simulate tidal circulation and salinity transport in estuaries and coastal bays. However, no studies have been conducted to evaluate tidal dynamics and salinity intrusion in the Snohomish River as a function of river flows under climate change and land use land cover (LULC) scenarios. To better understand nearshore habitat hydrodynamics and provide useful information to assist water management in the Snohomish River, a high resolution three-dimensional coastal model for the Snohomish River Estuary and its floodplain was developed based on previous study by Yang et al (2010). The model was applied to evaluate the hydrodynamic response to river inflow under future climate and LULC scenarios. Effects of sea-level rise on the estuarine hydrodynamics were also studied based on sea-level rise projections in the Puget Sound region by the end of the century (NRC 2013). Finally, a demonstration model run was conducted to simulate the fate and transport of fecal coliform (E. coli) discharge from the City of Everett outfall at Port Gardiner.

\section{II.1 Methods}

\section{II.1.1 Study Site}

The Snohomish River Estuary is located in the Whidbey Basin of Puget Sound, Washington, USA. The Snohomish River forms at the confluence of the Skyhomish River and Snoqualmie River at river kilometer 40 near the city of Monroe. The estuary connects to the Puget Sound Main Basin through Possession Sound in the west and the Saratoga Passage and Port Susan Bay in the north (Figure II - 1). The Snohomish River is the second largest river in Puget Sound and accounts for about $30 \%$ of the freshwater discharge to Whidbey Basin. The long-term annual average river flow, measured at the US Geological Survey (USGS) stream gage at the city of Monroe, is approximately $270 \mathrm{~m}^{3} / \mathrm{s}$. The river flow of Snohomish River varies seasonally, with recorded minimum monthly flow of $32 \mathrm{~m}^{3} / \mathrm{s}$ and maximum monthly flow of $838 \mathrm{~m}^{3} / \mathrm{s}$, based on 50 years of records from 1963 to 2012. 
The Snohomish River discharges into Possession Sound through several large distributaries, including Ebey Slough along the north side of Snohomish delta, Steamboat Slough and Union Slough through the middle of the delta, and the main Snohomish River along the south side of the delta and Everett Peninsula (Figure II - 2). The Snohomish River splits into the mainstem river channel and Ebey Slough around $13 \mathrm{~km}$ from the river mouth. The Steamboat Slough diverges from the mainstem river at $6.3 \mathrm{~km}$ and intersects with Ebey Slough at $8.5 \mathrm{~km}$ and 9.8 $\mathrm{km}$, respectively. The Union Slough diverges from Steamboat Slough at $4.0 \mathrm{~km}$ and re-joins it again at $1.4 \mathrm{~km}$. These distributary sloughs provide important wetland and fish habitat juvenile salmon rearing period before they migrate from freshwater to the saltwater environment (Greene and Beechie, 2004; Scheuerell et al., 2006).

Circulation in the Snohomish River estuary is dominated by tides from Puget Sound and strongly influenced by river inflow and the complex geometry in the lower estuary. There is a large shallow river delta present at the mouth of the Snohomish River as a result of upstream sediment loads and deposition. Many intertidal tide-flats and estuarine wetlands exist in the Lower Snohomish River Estuary. Density-induced currents are important in the Snohomish River estuary because of salinity stratification and intrusion. Well-defined two-layer estuarine circulation and variation of salinity gradients, in both the vertical and longitudinal directions, are distinct features in the Snohomish River Estuary (Yang et al 2010). 


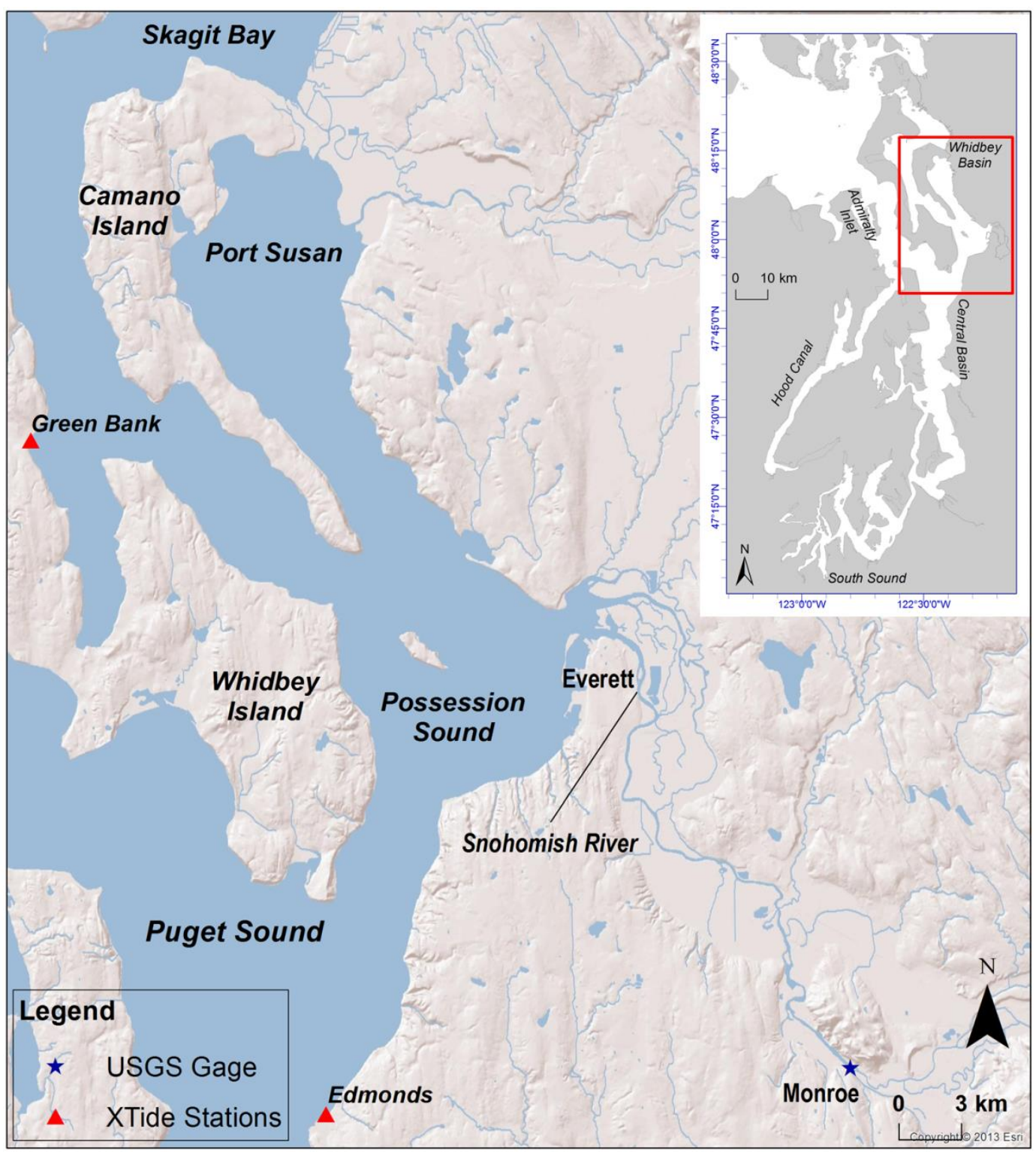

Figure II - 1. Snohomish River Estuary in Puget Sound, Washington, USA 


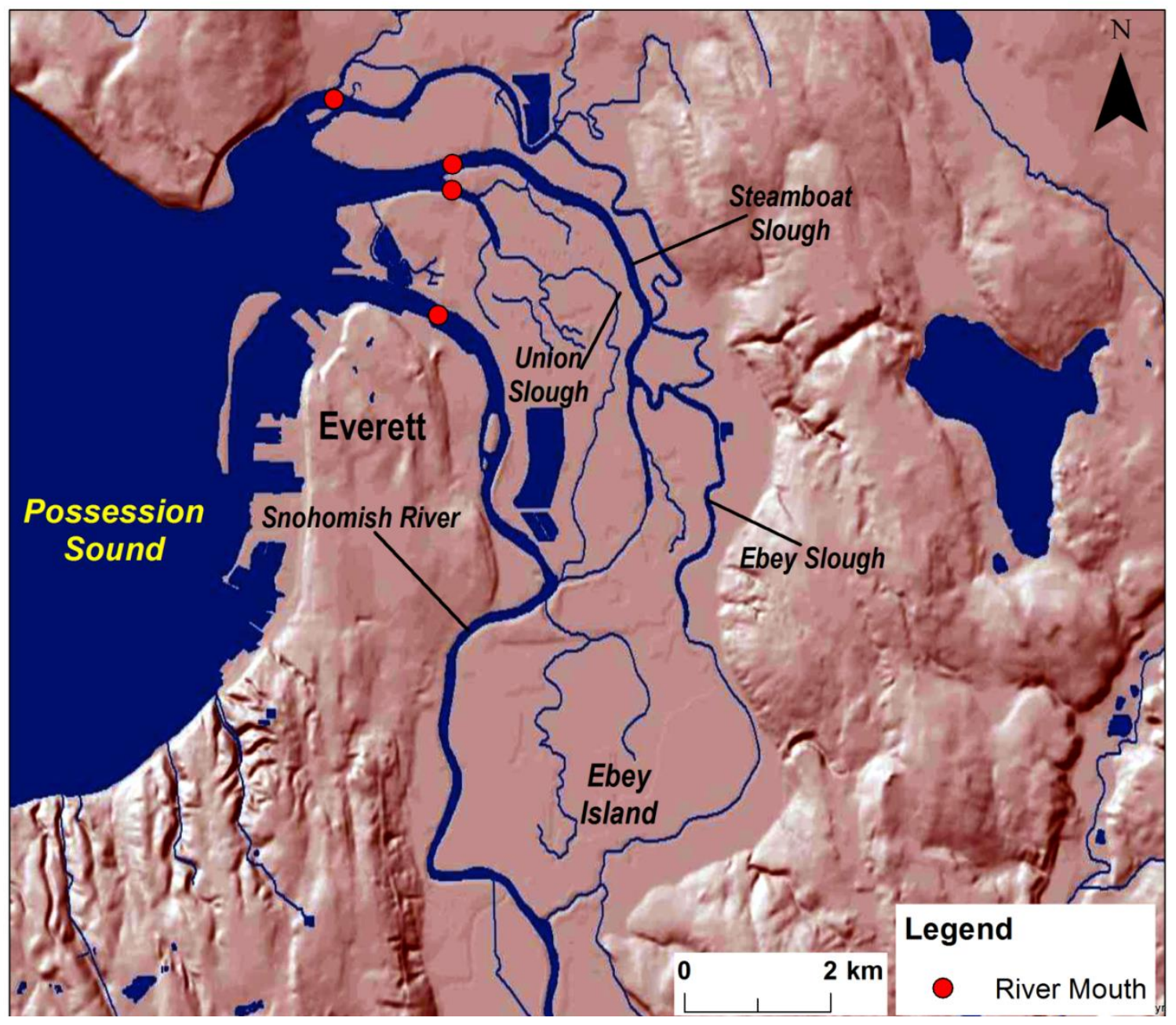

Figure II - 2. Distributary sloughs in the Lower Snohomish River Estuary

\section{II.1.2 Hydrodynamic Model of Snohomish River Estuary}

The hydrodynamic model used in this study is the Finite Volume Coastal Ocean Model FVCOM (Chen et al. 2003). FVCOM is a three-dimensional, unstructured-grid, finite volume coastal ocean model with a robust capability of simulating wetting and drying processes in the intertidal zone. FVCOM solves the 3D momentum, continuity, temperature, salinity, and density equations in an integral form for water-surface elevation and flow fields. Companion modules for sediment transport, water-quality kinetics, and biological models are also integrated into FVCOM. The model computes water depths, velocities, salinities and water-surface elevations based on the geometry and bathymetry of the system, the specified lateral and vertical boundary conditions, and model input parameters. FVCOM has been extensively applied to simulate hydrodynamics and transport processes in many coastal regions and estuaries around the world, including several estuaries and bays in Puget Sound (Zhao et al. 2006; Rego and Li, 2010; Dukhovskoy and Morey, 2011; Yang and Khangaonkar 2009; Yang et al 2010; 2012; Xing et al. 2012; Chen et al 2012; Yang and Wang 2013). 
An unstructured-grid for the Snohomish River Estuary and floodplain was developed based on a previous study by Yang et al. (2010). Water depth in the model was interpolated from bathymetric data from the digital elevation model for the main basin and LIght Detection And Ranging (LIDAR) data from Puget Sound LIDAR Consortium for the intertidal zone and floodplain. To minimize the open boundary effect on the tidal circulation and river plume dynamics, especially during high flow conditions, open boundaries were specified at the entrance of Possession Sound in the west and Saratoga Passage in the north. Port Susan Bay was also included in the model domain (Figure II - 3). However, river inflow from Stillaguamish River was not considered. The model consists of 57,030 nodes, 111,496 elements, and 10 vertical layers with exponential distribution. The element size varies from $250 \mathrm{~m}$ in the open boundary to as small as $15 \mathrm{~m}$ in the small channels in the wetlands and steep slope region in the Snohomish River Delta (Figure II - 4).

The model is forced by tides at the open boundaries and river inflow at the river head at City of Monroe. To focus on the effect of river inflow on the estuarine hydrodynamics, the effect of atmospheric forcing (wind and heat flux) was not considered in this study. Eight major tidal harmonic constituents $\left(\mathrm{M}_{2}, \mathrm{~S}_{2}, \mathrm{~N}_{2}, \mathrm{~K}_{2}, \mathrm{~K}_{1}, \mathrm{O}_{1}, \mathrm{P}_{1}\right.$, and $\left.\mathrm{Q}_{1}\right)$ were specified along the open boundaries using XTide predictions at Edmond station near the entrance of Possession Sound and Green Bank station in Saratoga Passage (Figure II - 1). Constant incoming salinity (30 ppt) was specified at the open boundary.
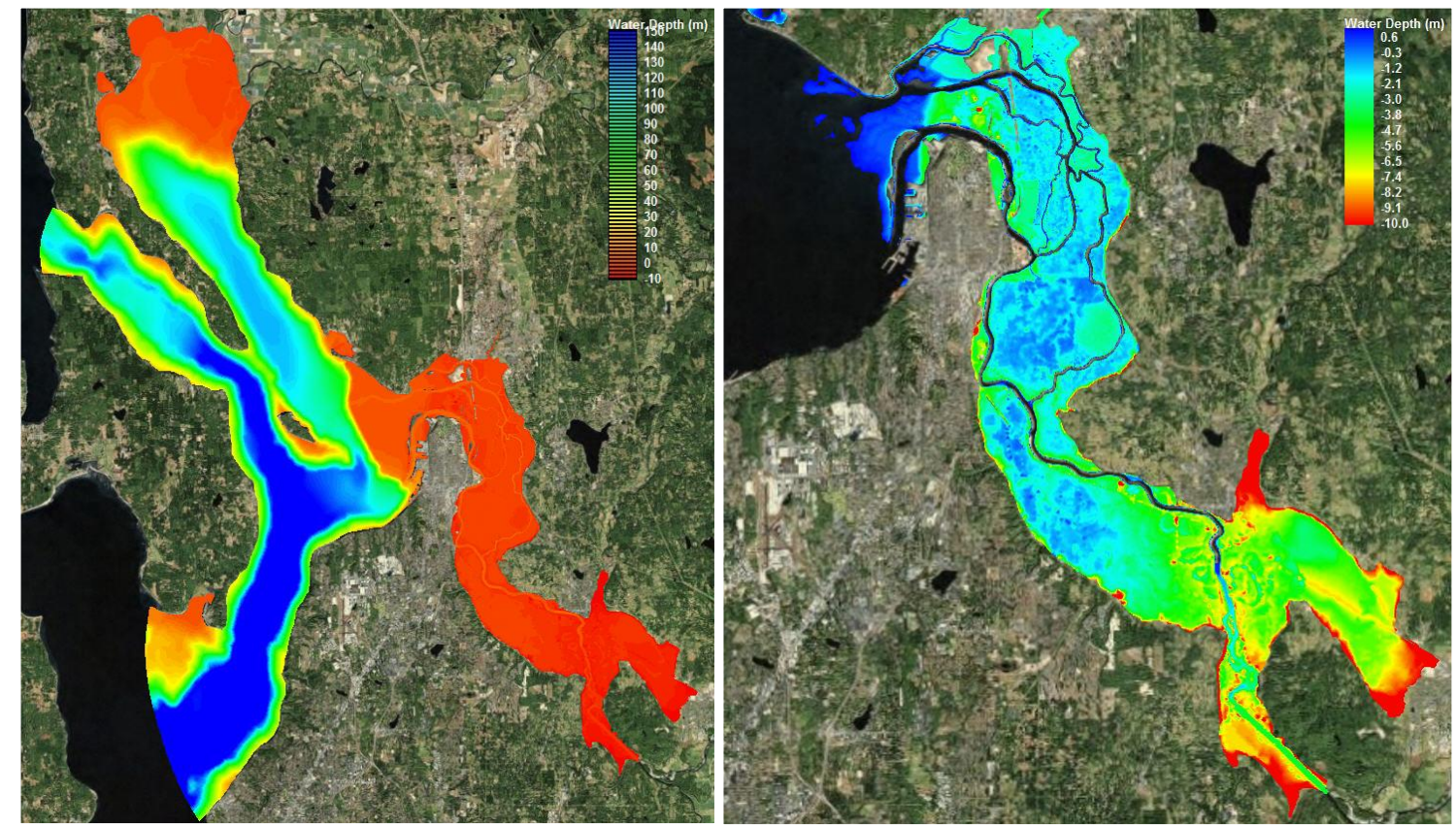

Figure II - 3. Model bathymetry (NAVD88) for the entire model domain (left) and the Lower River Estuary and Floodplain (right) 


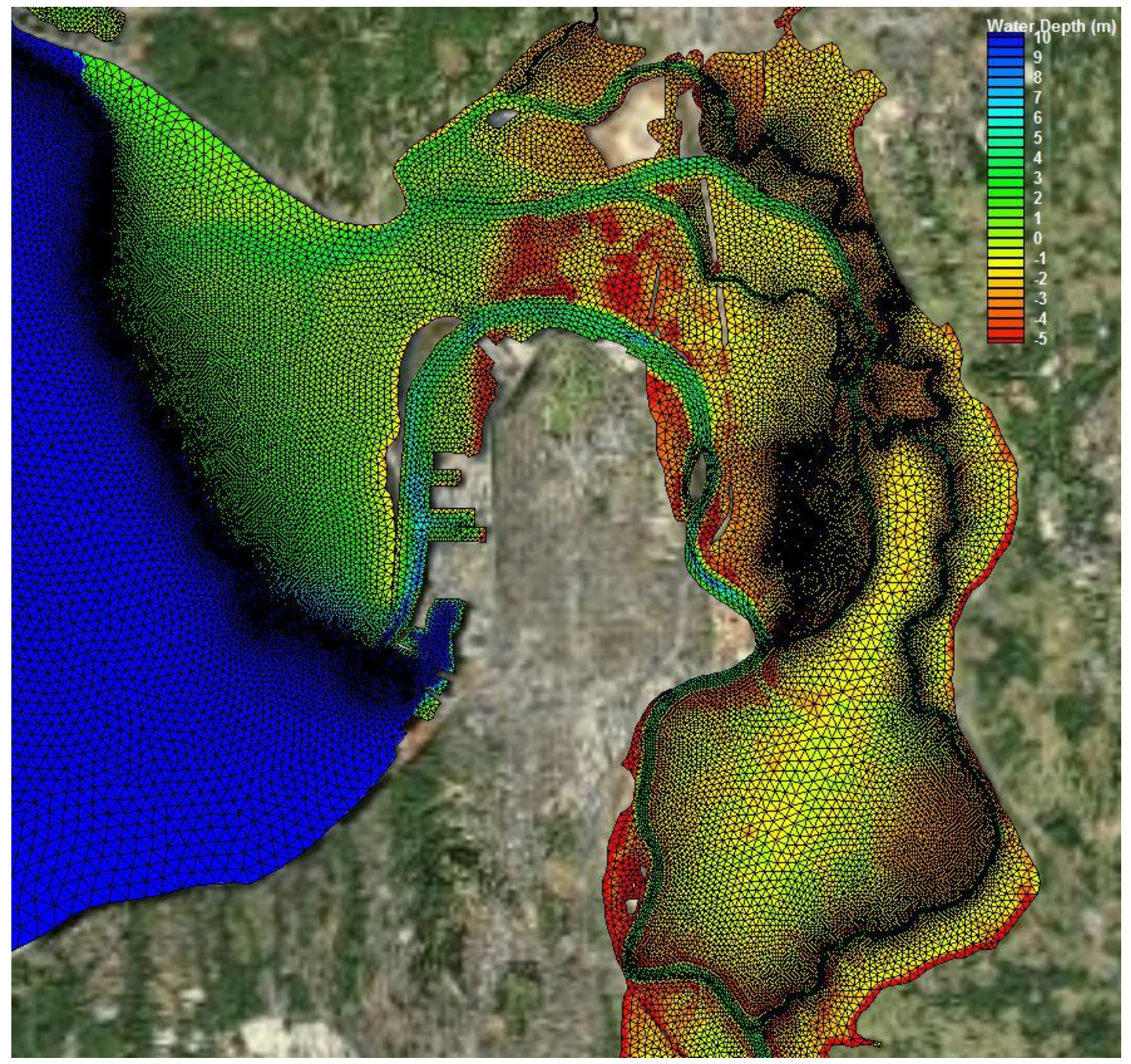

Figure II - 4. FVCOM unstructured-grid for the Lower Snohomish River Estuary

\section{II.1.3 Land Use Land Cover and Climate Change Scenarios}

Because the hydrodynamic response time to the river flow in the Snohomish River Estuary is short, typically in the order of days or less, it is not necessary to run the estuarine model for a long period covering seasonal variations. Instead, constant river flows that correspond to monthly mean flow conditions were used to study the estuarine hydrodynamic response to river flows under climate change and LULC scenarios.

To evaluate the effect of change in river flow as a result of climate change and LULC, longterm river flow results from hydrologic model simulations were analyzed. Hydrologic model simulations for the entire Snohomish watershed were conducted for the historical period from 1915 to 2006 using the Distributed Hydrology-Soil-Vegetation Model (DHSVM). A description of DHSVM is provided in Wigmosta et al. (1994, 2002). Model calibration against USGS stream gage records in Puget Sound and Snohomish River Basin is provided in Cuo et al. (2011). A 
detailed description of climate change and LULC scenarios is provided in Appendix I of this report and will not be repeated here.

River flow statistics from the long-term hydrology model simulations were analyzed using the following approach. First of all, monthly mean flows for the twelve months in each year of the simulation period were calculated. Then monthly ensemble averages of each of the twelve months for all the simulation years were calculated. The months for the lowest flow and the highest flow within the twelve monthly ensemble averages were determined as the lowest and highest monthly flow climatology, respectively. Finally, the lowest, average, and highest flows of all the years for the lowest and highest monthly flow climatology were analyzed. An average of all monthly mean flows was also calculated as an overall mean baseline condition.

A standard set of global greenhouse gas emissions scenarios has been defined by the Intergovernmental Panel on Climate Change (IPCC) as described in the IPCC Special Report on Emissions Scenarios (SRES) 2001 report (SRES, 2001). In this study, two specific emission scenarios, A1B and B1, were selected to drive the hydrology model simulations for the period of 2030 to 2050 . The A1B is a balance scenario across all energy sources within the A1 scenario family that describes a future world of very rapid economic growth, global population that peaks in mid-century and declines gradually, and the rapid introduction of new and more efficient technologies. The B1 storyline and scenario family describes a convergent world with the same global population as in the A1 storyline, but with rapid changes toward a service and information economy and reductions in material intensity and the introduction of clean and resource-efficient technologies (http://www.ipcc.ch/ipccreports/tar/wg1/029.htm ).

Statistics of monthly flows of the Snohomish River simulated by DHSVM under different LULC scenarios for the historical period (1915 - 2006) and climate change scenarios for the future period $(2030$ - 2050) are provided in Table II - 1 and Table II - 2, respectively. Figure II 5 shows the comparison of river flows for all climate change and LULC scenarios. Although at a long-term average time scale, river flows under climate change scenarios $\left(303 \mathrm{~m}^{3} / \mathrm{s}\right)$ are comparable to the flows under historical $\left(297 \mathrm{~m}^{3} / \mathrm{s}\right)$ and future LULC $\left(314 \mathrm{~m}^{3} / \mathrm{s}\right)$ scenarios. Future climate change shows stronger effects on the extremes than LULC, i.e, river flows under climate change scenarios is lower than those under LULC scenarios for the lowest monthly climatology, but higher for the highest monthly climatology.

Extreme daily low and high flows simulated by DHSVM for historical period (1915 - 2006) and 2002 LULC condition, as well as future climate change scenarios (A1B and B1) are provided in Table II - 3. The daily minimum and maximum flows for the climate change scenarios are approximately $15 \mathrm{~m}^{3} / \mathrm{s}$ and $2526 \mathrm{~m} 3 / \mathrm{s}$, respectively. The daily minimum flow for the historical period is slightly smaller and the maximum flow is slightly greater compared to the climate change scenarios. 
Table II - 1. Monthly Average Flows (m3/s) from DHSVM Simulations for LULC 2002 and LULC 2050 Scenarios under Historical Climate Condition (1915 - 2006)

\begin{tabular}{|c|c|c|c|}
\hline \multicolumn{2}{|c|}{ Description of DHSVM Model Output } & LULC 2002 & LULC 2050 \\
\hline \multicolumn{2}{|c|}{ Average of Monthly Mean Flows (AMM) } & 297 & 314 \\
\hline \multirow{3}{*}{$\begin{array}{c}\text { Lowest Monthly } \\
\text { Climatology (1915 - } \\
\text { 2006) }\end{array}$} & Lowest Flow (LLM) & 30 & 33 \\
\hline & Average Flow (ALM) & 71 & 81 \\
\hline & Highest Flow (HLM) & 149 & 176 \\
\hline \multirow{3}{*}{$\begin{array}{l}\text { Highest Monthly } \\
\text { Climatology (1915 - } \\
\text { 2006) }\end{array}$} & Lowest Flow (LLM) & 155 & 171 \\
\hline & Average Flow (ALM) & 474 & 498 \\
\hline & Highest Flow (HLM) & 1190 & 1222 \\
\hline
\end{tabular}

Table II - 2. Monthly Average Flows (m3/s) from DHSVM Simulations for Future Climate Change A1B and B1 Emission Scenarios under LULC 2002 condition (20302050)

\begin{tabular}{|c|c|c|c|}
\hline \multicolumn{2}{|c|}{ Description of DHSVM Model Output } & A1B & B1 \\
\hline \multicolumn{2}{|c|}{ Average of Monthly Mean Flows (AMM) } & 303 & 303 \\
\hline \multirow{3}{*}{$\begin{array}{l}\text { Lowest Monthly } \\
\text { Climatology (2030- } \\
\text { 2050) }\end{array}$} & Lowest Flow (LLM) & 24 & 55 \\
\hline & Average Flow (ALM) & 50 & 117 \\
\hline & Highest Flow (HLM) & 100 & 191 \\
\hline \multirow{3}{*}{$\begin{array}{l}\text { Highest Monthly } \\
\text { Climatology (2030- } \\
\text { 2050) }\end{array}$} & Lowest Flow (LLM) & 193 & 571 \\
\hline & Average Flow (ALM) & 575 & 498 \\
\hline & Highest Flow (HLM) & 1445 & 1441 \\
\hline
\end{tabular}




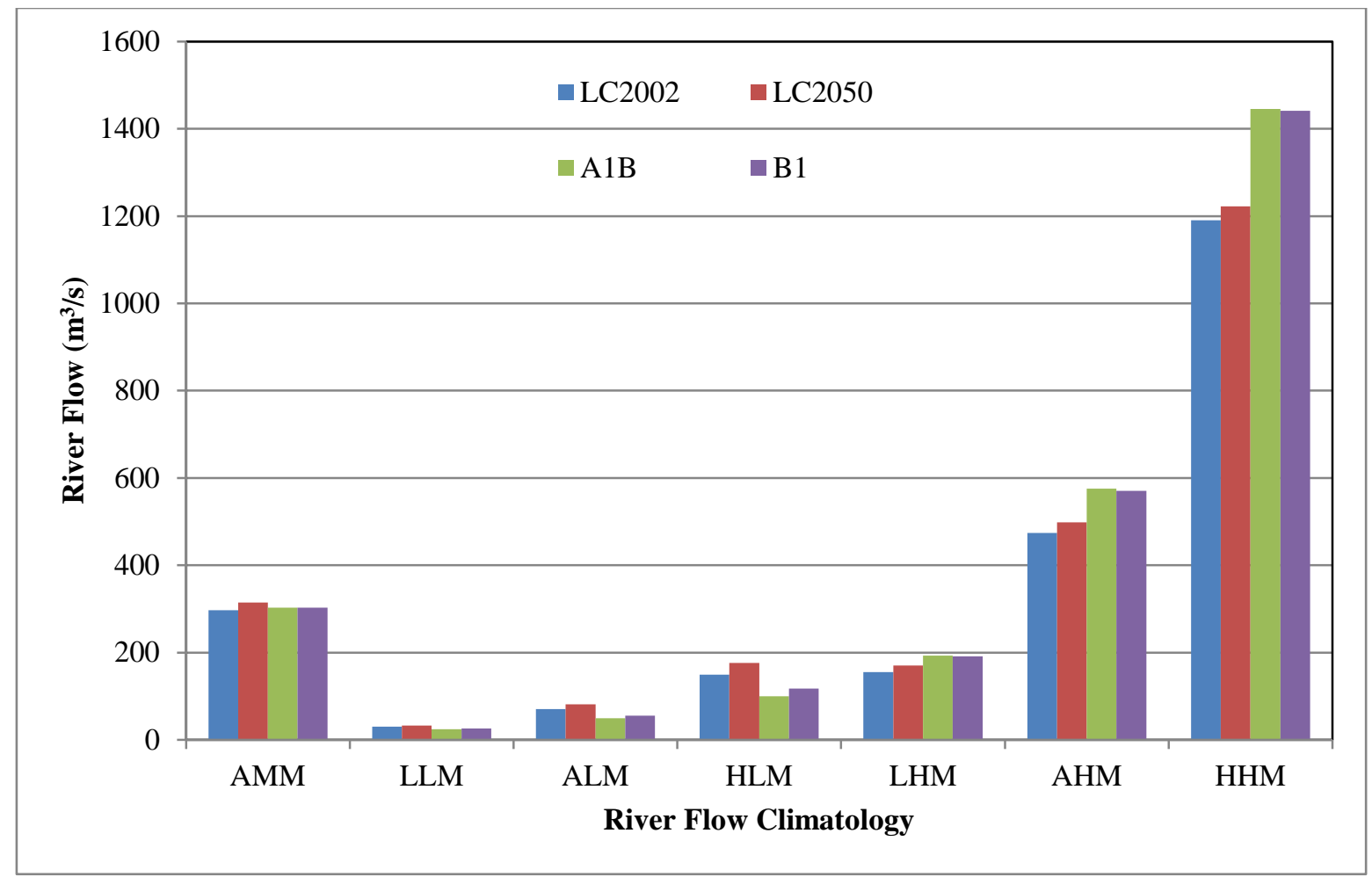

Figure II - 5. Comparisons of simulated river flows by DHSVM for different climate change and land use scenarios (AMM - Average Monthly Mean flow; LLM - Lowest flow of Lowest Monthly climatology; ALM - Average flow of Lowest Monthly climatology; HLM - Highest flow of Lowest Monthly climatology; LHM Lowest flow of Highest Monthly climatology; AHM - Average flow of Highest Monthly climatology; HHM - Highest flow of Highest Monthly climatology)

Table II - 3. Daily minimum and maximum flows (m3/s) from DHSVM simulations for historical conditions (1916 - 2006) and Climate Change A1B and B1 Scenarios (2030-2050)

\begin{tabular}{||c|c|c|c||}
\hline DHSVM Output & LC2002 & A1B & B1 \\
\hline \hline Daily Minimum & 17.8 & 14.5 & 15.6 \\
\hline Daily Maximum & 2051.9 & 2533.4 & 2518.2 \\
\hline
\end{tabular}

One of the most distinct features as a result of climate change is the rise of sea-level. Effects of sea-level rise on the estuarine hydrodynamics in Snohomish River were investigated by superimposing the values of sea-level rise on top of the tidal elevation boundary conditions. In 
order to separate the effects of sea-level rise and change of river flow due to future climate change and LULC, sea-level rise scenarios were only simulated with river flow under historical monthly lowest, average and highest flow conditions.

\section{II.1.4 Modeling Approach and Simulation Design}

As indicated in Figure II - 5, statistics for the lowest and highest monthly mean flow conditions only cover a few narrow ranges of river flow regime. For example, large flow gaps exist between lowest (LHM), average (AHM) and highest (HHM) flows in highest monthly climatology. In order to evaluate the estuarine hydrodynamic response to river flow conditions that cover the full range of seasonal variability (from dry to wet seasons), a series of model runs were conducted using river flows that vary from the extremely low flow (dry season) to extremely high flow (wet season) conditions with various increments in flow values. A total of 20 model runs were conducted with river flow ranging from $30 \mathrm{~m}^{3} / \mathrm{s}$ to $1440 \mathrm{~m}^{3} / \mathrm{s}$ with finer flow increment in the low flow regime. Two additional model runs with river flow of $15 \mathrm{~m}^{3} / \mathrm{s}$ and $2520 \mathrm{~m}^{3} / \mathrm{s}$ were also conducted to simulate the estuarine hydrodynamic response to extreme flow events based on the DHSVM model outputs of daily minimum and maximum flows for the historical simulation period (1915 - 2006).

The response of estuarine hydrodynamics to river flow were quantified by following parameters: 1) salinity intrusion point in each of the river distributaries; 2) inundated area in the intertidal zone and floodplain; 3) average water depth and 4) average salinity in the inundated area. Analytical formulas that relate these parameters to river flows were generated based on the estuarine hydrodynamic model results. Responses of these parameters to the climate change and LULC scenarios then can be interpolated based on the analytical formulas. 


\section{II.2 Results and Discussion}

\section{II.2.1 Hydrodynamics of Snohomish River Estuary}

A baseline model simulation representing the normal hydrodynamic condition in the Snohomish River Estuary was conducted using the long-term monthly average flow of $270 \mathrm{~m} 3 / \mathrm{s}$ based on 50-year flow records at the USGS stream gage at Monroe. The FVCOM model was run for a period of 30-days. The first 15-days served as a spin-up time in order for the model to reach dynamic equilibrium. Model results for the last 15 days were used for the response analysis.

Figure II - 6 shows the time series of water surface elevation at the mouth of the Snohomish River. There is strong spring-neap tidal variability in the estuary, with the tidal range varying from $3.5 \mathrm{~m}$ during spring tides to about $2.0 \mathrm{~m}$ during neap tides. Distinct tidal diurnal inequality is also seen within the spring-neap tidal cycle, e.g., weaker semi-diurnal tides during neap tides and stronger semi-diurnal tide during spring tides.

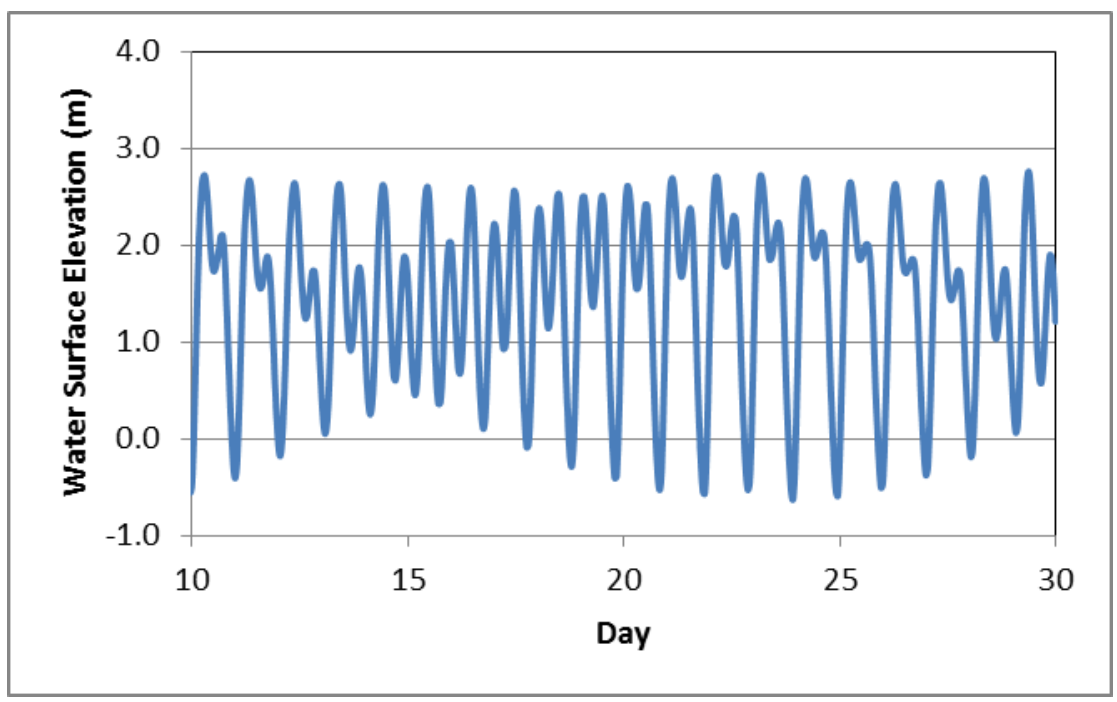

Figure II - 6. Water surface elevation at the river mouth of the Snohomish River Estuary relative to NAVD88 vertical datum

Time series of surface and bottom salinity at the river mouths of the main river, Union Slough, Steamboat Slough and Ebey Slough are shown in Figure II - 7. Strong salinity stratification is present in all the tributaries. Bottom salinities are generally greater than $12 \mathrm{ppt}$ during flood tides in all tributaries and drop below 3 ppt during ebb tides under mean river flow condition, indicating strong tidal variability over a tidal cycle.

To further analyze salinity stratification in the estuary, salinity differences between bottom and surface salinities in the distributaries were calculated and are shown in Figure II - 8. Salinity stratification is strongest in the main Snohomish River; salinity differences between surface and 
bottom layer can be as large as 10 ppt during flood tide under mean flow condition. It is interesting to see that stratification in Union Slough is the second strongest although the mean tidal transport is the smallest in this slough among the four distributaries (Yang et al 2010). Maximum salinity difference at the mouths of Steamboat and Ebey Sloughs are approximately 5 ppt, roughly half that in the main river. Strong diurnal inequality in salinity stratification is shown in Figure II - 8, with the dominant diurnal cycle from day 11 to 15 (and from day 25 to 30) and the semi-diurnal cycle from day 17 to 23.

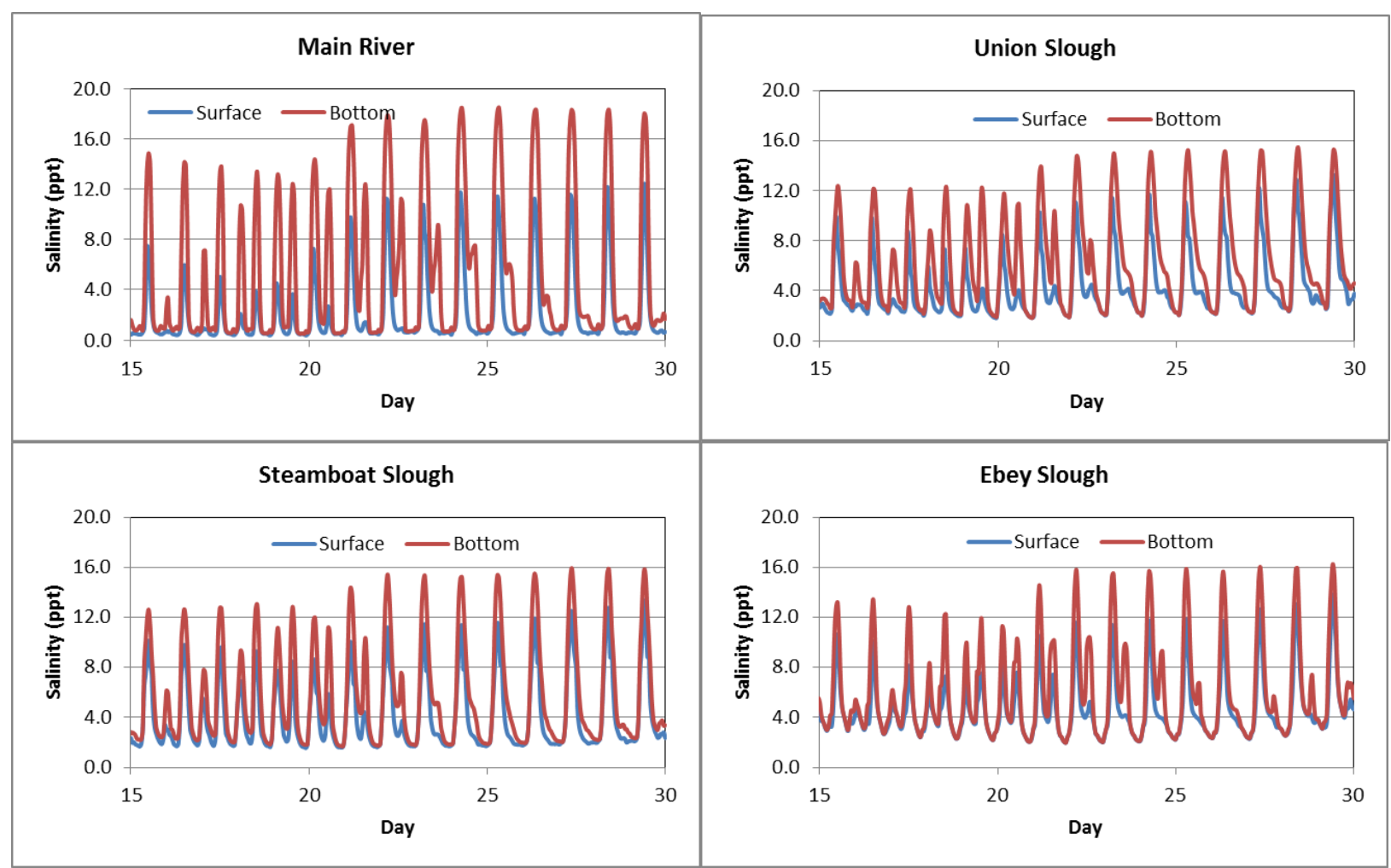

Figure II - 7. Salinity time series at the mouths of Snohomish River main-stem, Steamboat Slough and Ebey Slough under average monthly mean flow condition $\left(270 \mathrm{~m}^{3} / \mathrm{s}\right)$ 


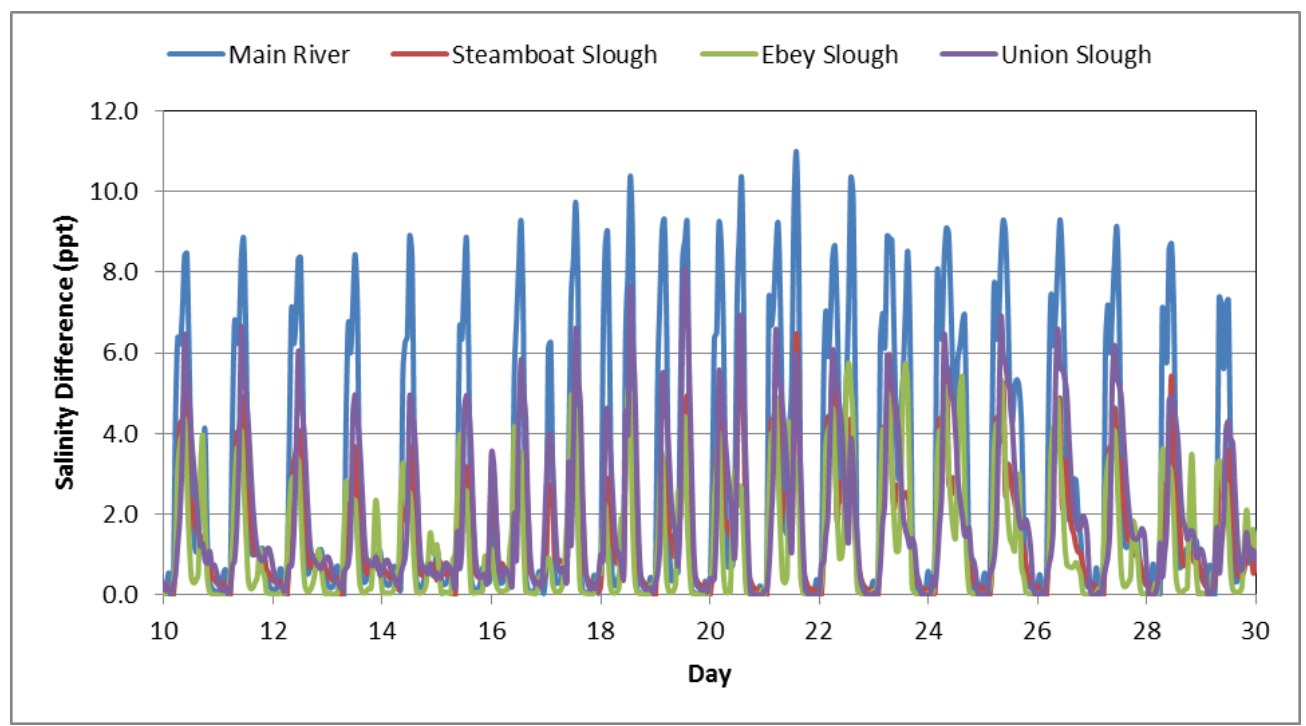

Figure II - 8. Salinity difference (bottom - surface) at the river mouths of Snohomish River, Steamboat Slough and Ebey Slough under average monthly mean flow condition $\left(270 \mathrm{~m}^{3} / \mathrm{s}\right)$

Horizontal 2D plots of surface salinity and velocity distributions in the estuary are shown in Figure II - 9. Salinity distribution is shown as color contours with a cut-off value of 0.5 ppt to represent the limit of salinity intrusion in the estuary. Overall, surface salinity in the lower estuary is relatively low ( $<12 \mathrm{ppt})$, which is also shown in the time series plots (Figure II - 7). Salinities in the tidal wetland areas are typically below 2 ppt. Surface velocities in the low estuary are dominant in the out-going direction because freshwater from the river flows out of the estuary in the surface layer.
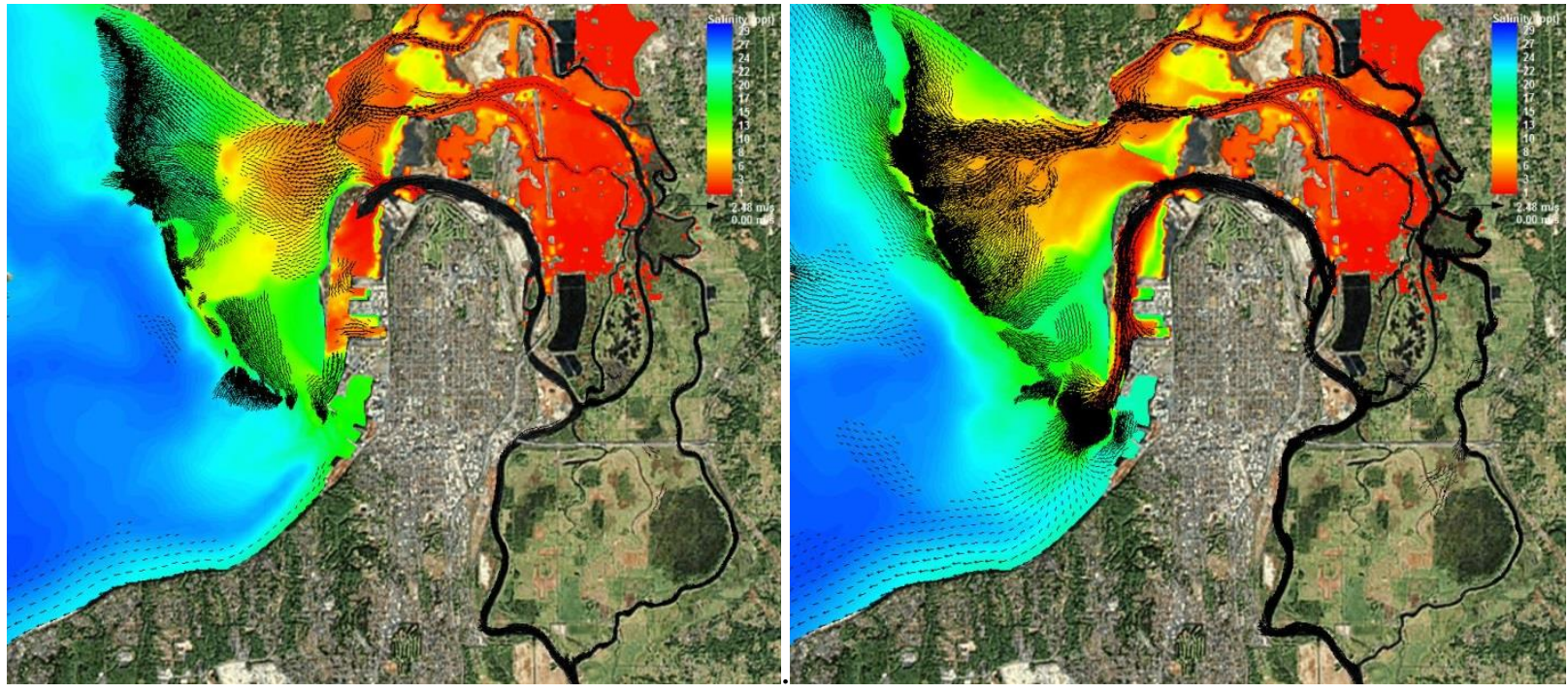

Figure II - 9. surface salinity and velocity distributions in the Lower Snohomish River Estuary during flood (left) and ebb (right) tides 


\section{II.2.2 Salinity Intrusion in the Distributaries}

In this study, salinity intrusion at any given time in the river distributary was defined as the distance from the location where bottom salinity reaches $0.5 \mathrm{ppt}$, to the river month. The location of the river mouth for each distributary was based on the definition from the Washington State Department of Ecology (Figure II - 2).

Salinity intrusion points in an estuary highly depend on the dynamic balance of tide and river flow and can vary significantly over spatial and temporal scales. Location of salinity intrusion moves up- and down-stream in an estuary during a tidal cycle, and is marked over a spring-neap cycle. To evaluate the mean salinity intrusion point as a function of river flow, salinity intrusion points were calculated based on the average of bottom salinity over a 14 day period, covering a spring-neap tidal cycle. Simulated distances of salinity intrusion points from the river mouths of the main Snohomish River, Union Slough, Steamboat Slough, Ebey Slough, are shown in Figure II - 10. A positive distance of salinity intrusion indicates the intrusion point is upstream of the river mouth. The distance of salinity intrusion becomes negative when the intrusion point is downstream of the river mouth. As shown in Fig. 10, the distance of salinity intrusion is a nonlinear function of river flow. The distance of salinity intrusion has a greater gradient with respect to river flow for the lower flow range. When the river flow is in the upper range (> 700 $800 \mathrm{~m}^{3} / \mathrm{s}$ ), the response of salinity intrusion points to the change of river flow becomes small. It is noted that under low flow conditions, salinity intrusion points do not exist in Union Slough and Steamboat Sloughs (Figure II - 10). Salinity intrusion points in Union and Steamboat Slough were push upstream by tides and joined the salinity intrusion point in the main river under low flow conditions (approximately less than $150 \mathrm{~m}^{3} / \mathrm{s}$ for Union Slough and less than $100 \mathrm{~m}^{3} / \mathrm{s}$ for Steamboat Slough).

A second- or third-order polynomial regression fit is necessary to relate salinity intrusion points to the river flows, because of the nonlinear response of estuarine hydrodynamics. The $\mathrm{R}^{2}$ values for all the distributaries are around 0.98 (see Figure II - 10). Specifically, the following regression formulas were developed to relate the salinity intrusion points (distance from the river mouth $D(\mathrm{~m})$ ) to the river flow $Q\left(\mathrm{~m}^{3}\right)$ in the distributaries of Snohomish River Estuary:

$$
\begin{array}{rc}
\text { Main River } \quad D=-5 \times 10^{-6} Q^{3}+0.0194 Q^{2}-24.568 Q+7038 ; & R^{2}=0.9938 \\
\text { Union Slough } \quad D=-3 \times 10^{-6} Q^{3}+0.0192 Q^{2}-32.683 Q+12832 ; & R^{2}=0.9973 \\
\text { Steamboat Slough } \quad D=0.009 Q^{2}-23.679 Q+10955 ; & R^{2}=0.9918 \\
\text { Union Slough } \quad D=-1 \times 10^{-6} Q^{3}+0.0181 Q^{2}-36.805 Q+16774 ; & R^{2}=0.9975
\end{array}
$$

These formulas are only valid for river flows below the upper limit of $1450 \mathrm{~m}^{3} / \mathrm{s}$ used in the model simulation. 

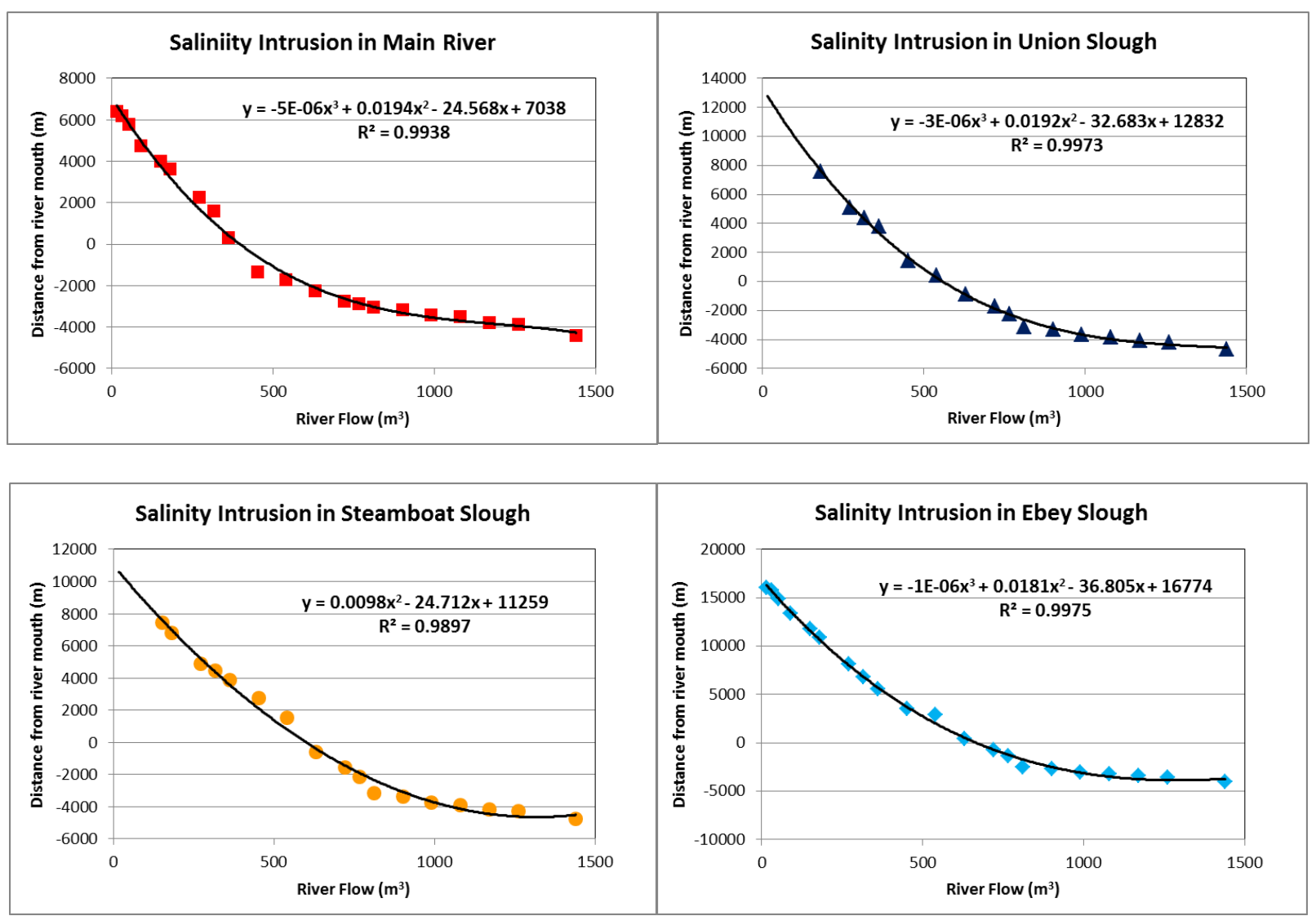

Figure II - 10 Salinity intrusion points in the Snohomish River distributaries as a function of river flow (Note: negative distance means the salinity intrusion point is downstream of the river mouth)

Based on the model results in Figure II - 10 and Eq. 1 to 4, the distribution patterns of salinity intrusion points in all the distributaries are similar. To further evaluate the differences, salinity intrusion points in all the distributaries are compared in Figure II - 11. Clearly, the gradients of salinity intrusion points are quite different between the distributaries when river flow is roughly below $800 \mathrm{~m}^{3} / \mathrm{s}$. The salinity intrusion point was greatest gradient in Ebey Slough, indicating salinity intrusion is most sensitive to river flow in Ebey Slough. The gradient is the lowest in the main Snohomish river, indicating salinity intrusion in the main river is the least sensitive to river flow among all the distributaries. The gradients of salinity intrusion points in Union Slough and Steamboat Slough are similar, both falling between Ebey Slough and the main river. It is interesting to see from Figure II - 11 that the distribution patterns of salinity intrusion points merge together when river flow is greater than approximately $800 \mathrm{~m}^{3} / \mathrm{s}$ as high river flow pushes the salt limit downstream of the river mouth. The value of $800 \mathrm{~m}^{3} / \mathrm{s}$ is about the same as the maximum monthly mean flow $\left(838 \mathrm{~m}^{3} / \mathrm{s}\right)$ based on the historical stream gage records in Monroe. Figure II - 11 also indicates that the amount of river flow required to push the salinity intrusion point to the river mouth (i.e., zero distance) increases from the main river, to Union Slough and Steamboat Slough, and finally to Ebey Slough. Based on Eq. 1 to 4, we can determine the river flows corresponding to salinity intrusion points at the river mouths of each distributary are $400 \mathrm{~m}^{3} / \mathrm{s}$ for the main river, $562 \mathrm{~m}^{3} / \mathrm{s}$ for Union Slough, $597 \mathrm{~m}^{3} / \mathrm{s}$ for Steamboat 
Slough and $666 \mathrm{~m}^{3} / \mathrm{s}$ for Ebey Slough. One can see that it requires much higher river flow to push the salt limit to the river mouth of Ebey Slough, because Ebey Slough has the longest distance from the river mouth to the river head, and has the smallest channel cross-section, except for Union Slough.

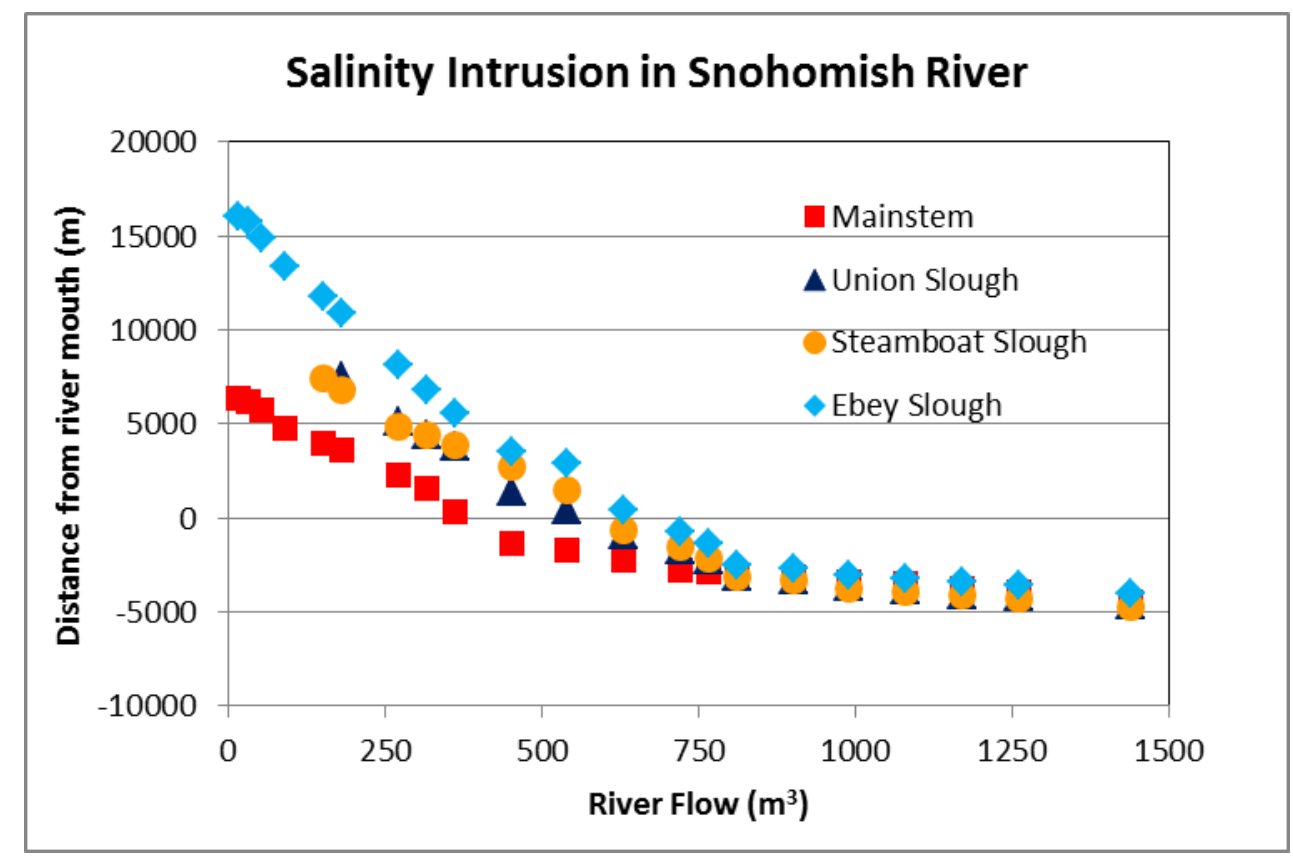

Figure II - 11. Comparison of salinity intrusion points in the distributaries of Snohomish River Estuary (Note: negative distance means the salinity intrusion point is downstream of the river mouth)

\section{II.2.3 Inundation in Intertidal Zone and River Floodplain}

In addition to salinity intrusion point, effects of river flow on the inundation area, average water depth and salinity of the inundated area in the intertidal zone and floodplain of the lower estuary were analyzed. The intertidal zone was defined as the area between high tide and low tide that experiences wetting-drying process during a spring tidal cycle. The area of the floodplain was determined based on the floodplain boundary of the lower Snohomish River Estuary defined by Federal Emergency Management Agency (FEMA), as shown in green area in Figure II - 12.

To evaluate the response of inundated area to river flow, average inundated area over a spring-neap tidal cycle under mean flow $\left(270 \mathrm{~m}^{3} / \mathrm{s}\right)$ condition was first calculated to serve as a baseline scenario. All other model runs with different river flows were normalized to the baseline scenario to show the relative change (percentage) in inundated area. Figure II - 13 shows that inundation area was decreased by about $10 \%$ when river flow was reduced to the lowest monthly mean of $30 \mathrm{~m}^{3} / \mathrm{s}$. When river flow was increased to around $800 \mathrm{~m}^{3} / \mathrm{s}$, the inundation area increased by about $15 \%$. However, as river flow continued to increase and pass $800 \mathrm{~m}^{3} / \mathrm{s}$, there was a sudden jump in the change of inundation area, indicating water overtopped 
the levee along the river bank and inundated the floodplain area. Comparison of inundated areas at low tide between model runs with river flow of $765 \mathrm{~m}^{3} / \mathrm{s}$ and $810 \mathrm{~m}^{3} / \mathrm{s}$ is shown in Figure II 14. Clearly, a large area in the upstream floodplain of the model domain was inundated by water. Figure II - 13 shows that the inundated area increases linearly as a function of river flow, which can be described by the following linear equation:

$$
A_{\text {avg }}=0.0458 Q+87.578 ; \quad R^{2}=0.9621
$$

Spatially- and temporally-averaged water depth of the inundated area over a spring-neap tidal cycle was calculated for all the model runs (Figure II - 15). The response of the average water depth in the inundated area to the river flow was not significant. The average water depth increased linearly with a very small gradient as a function of river flow and varied from $1.36 \mathrm{~m}$ for the lowest flow condition $\left(30 \mathrm{~m}^{3} / \mathrm{s}\right)$ to $1.73 \mathrm{~m}$ for the highest flow condition $\left(1440 \mathrm{~m}^{3} / \mathrm{s}\right)$. A linear correlation between the average water depth of the inundated area and the river flow is found as follows:

$$
H_{\text {avg }}=0.0003 Q+1.3396 ; \quad R^{2}=0.9795
$$

Spatially- and temporally-averaged salinity of the inundated area over a spring-neap tidal cycle was calculated for all the model runs (Figure II - 16). Average salinity in the inundated area varies from $16 \mathrm{ppt}$ at low flow condition to $4.6 \mathrm{ppt}$ at high flow condition. Unlike average water depth in the inundated area, average salinity in the inundated area is a second-order polynomial function with respect to river flow:

$$
S_{\text {avg }}=0.000006 Q^{2}-0.0168 Q+16.543 ; \quad R^{2}=0.9929
$$

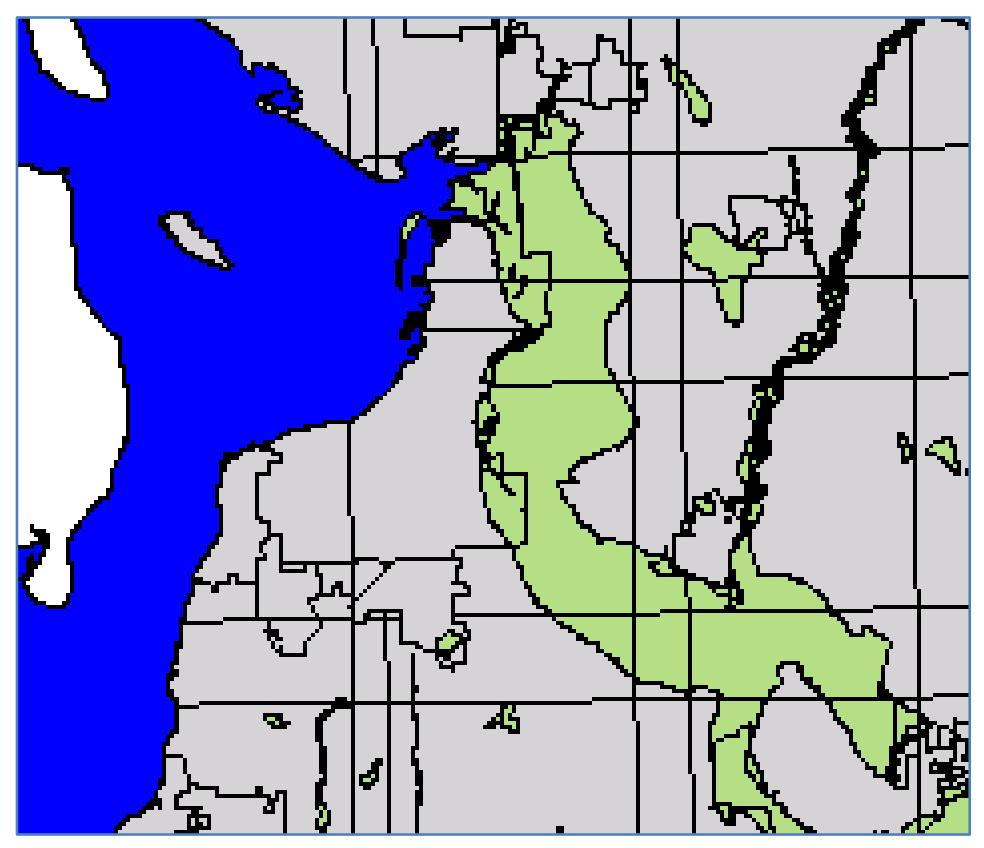

Figure II - 12 Floodplain (green color) in the lower Snohomish River Estuary defined by FEMA 


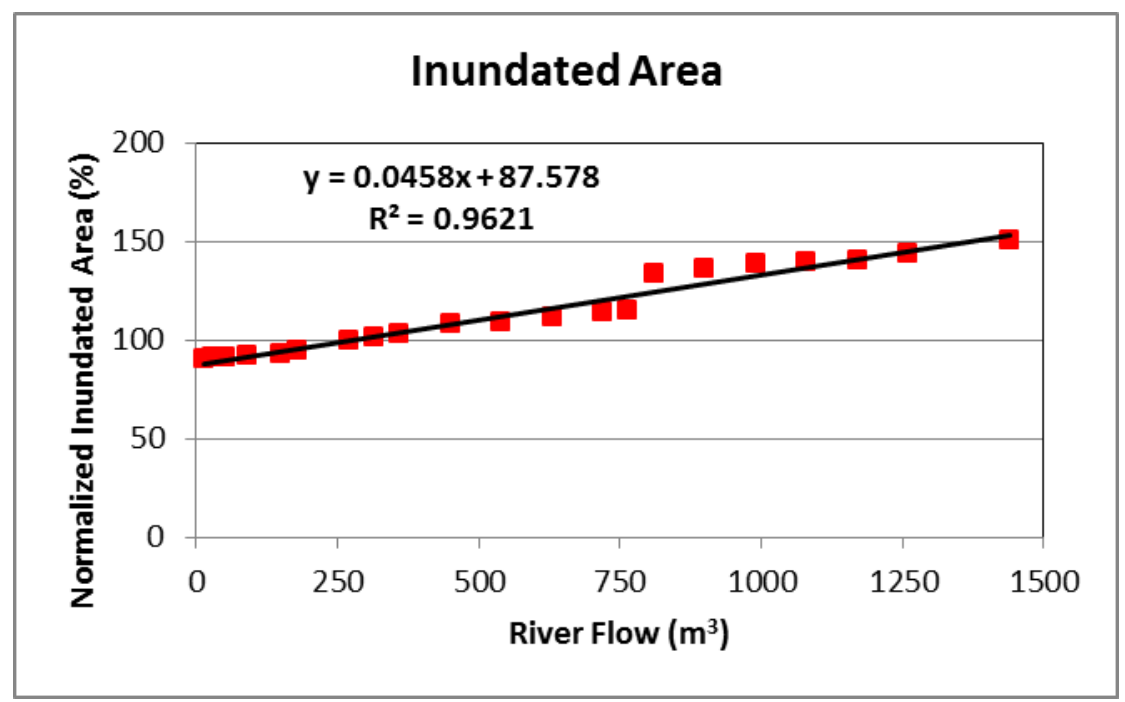

Figure II - 13. Normalized inundated area in tidal wetland and floodplain of Snohomish River Estuary
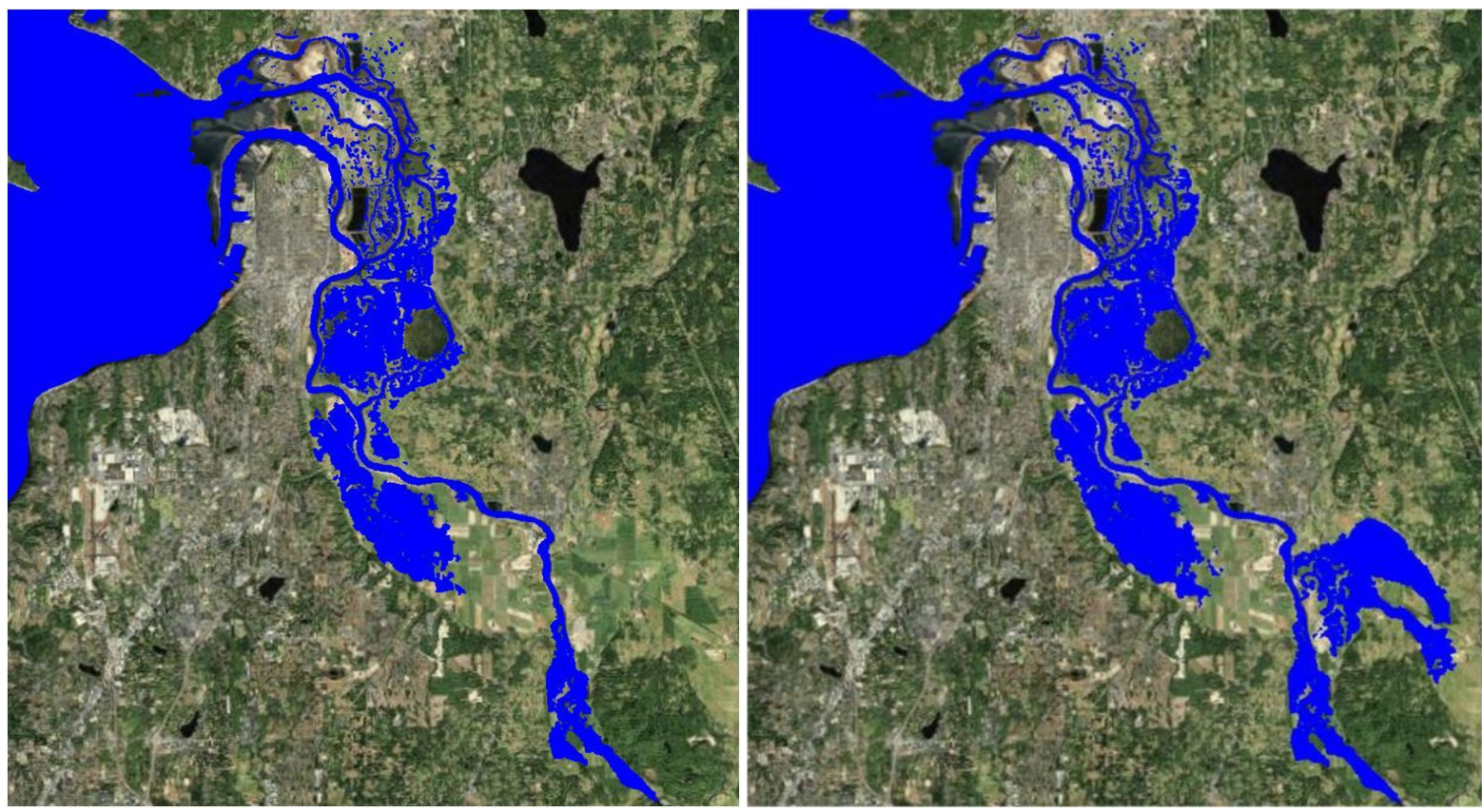

Figure II - 14. Comparisons of inundated areas at low tide between river flow of $765 \mathrm{~m}^{3} / \mathrm{s}$ (left) and $810 \mathrm{~m}^{3} / \mathrm{s}$ (right) conditions 


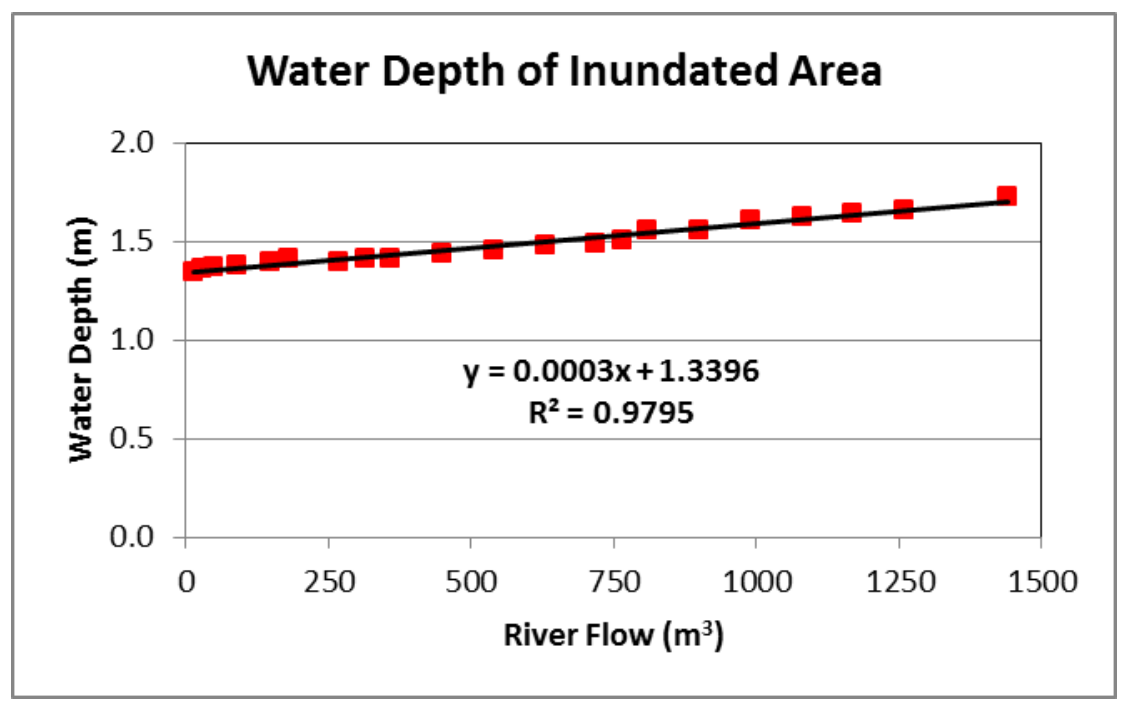

Figure II - 15. Average water depth of inundated area in tidal wetland and floodplain of Snohomish River Estuary

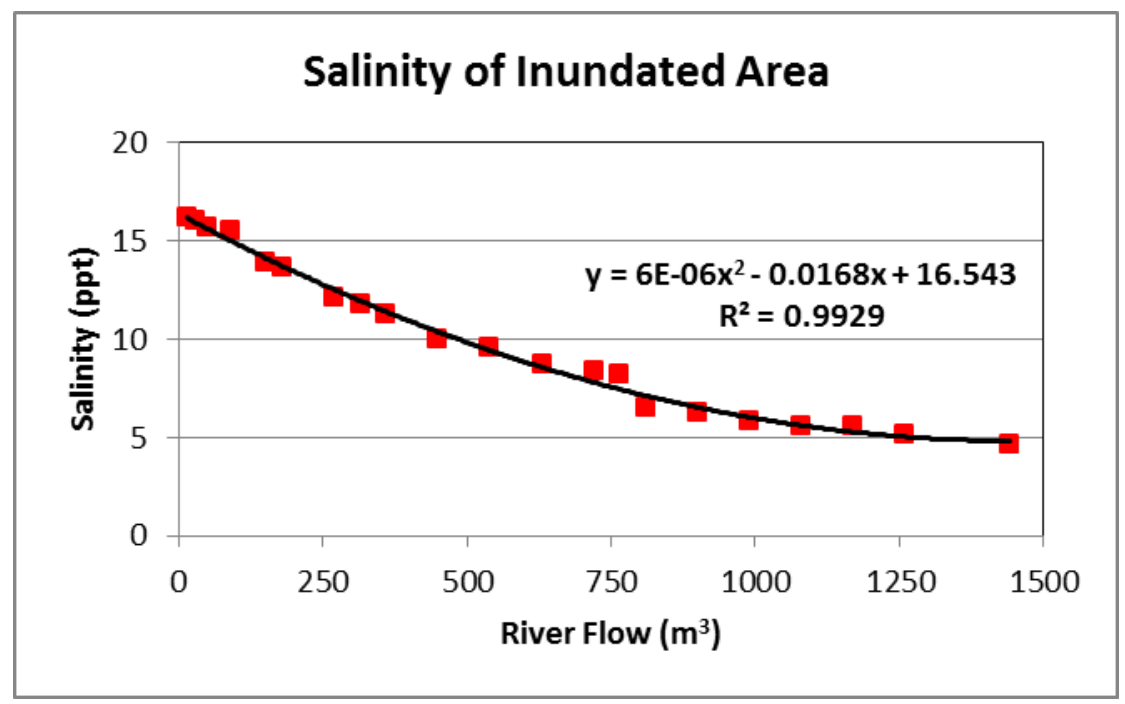

Figure II - 16. Average salinity of inundated area in tidal wetland and floodplain of Snohomish River Estuary

\section{II.2.4 Estuarine Response to Climate Change and LULC Scenarios}

Once the relationships between estuarine hydrodynamic parameters (i.e., salinity intrusion points, inundation area, water depth and salinity of inundated area) and river flow are established (Eq. 1 to 7), we can determine the values of these parameters under any river flow conditions. To evaluate the response of estuarine hydrodynamics to the climate change and LULC scenarios, as listed in Table II - 1 and Table II - 2, salinity intrusion points in the distributaries, normalized inundation area, average water depth and salinity of the inundated area were calculated using Eq. 
1 to 7 , which were developed based on a series of model simulations with river flows covering the entire flow range outputted by DHSVM under climate and LULC scenarios.

Calculated salinity intrusion points in the main river, Union Slough, Steamboat Slough and Ebey Slough are shown in Figure II - 17. Values missing in the Union Slough and Steamboat Slough plots in Figure II - 17 are due to the fact that salinity intrusion points were pushed upstream to the main river by tides under low river flow conditions. Normalized inundated area, average water depth and salinity in the inundated area under climate change and LULC scenarios are shown in Figure II - 18 to Figure II - 20. Figure II - 18 and 19 show that the effects on inundated area and water depth due to the change in climate and LULC are very similar, except for the highest monthly flow condition (HHM) in which climate change causes more area of inundation and increases the depth of the inundated area greatly. Under low flow conditions, effects on inundation and area and water depth are relatively small for both climate change and LULC. However, changes in climate and LULC result in significant changes in the average salinity in the inundated area (Figure II - 20) under all flow conditions. LULC scenarios show slightly less effect that climate change in the low flow regime but greater effect in the high flow regime.

To evaluate the effect of hydrology conditions under extreme climate change scenarios on estuarine hydrodynamics, daily minimum and maximum values of DHSVM outputs were analyzed. Model simulations were conducted to further examine the estuarine hydrodynamics in response to two extreme river flow values of $15 \mathrm{~m} 3 / \mathrm{s}$ and $2520 \mathrm{~m} 3 / \mathrm{s}$. which approximately correspond to the daily minimum and maximum flows of climate change scenarios. Model results showed that the estuarine hydrodynamics under daily minimum flow are not significantly different from those under the monthly low flow condition because the absolute value of daily minimum $(15 \mathrm{~m} 3 / \mathrm{s})$ is not much different from the lowest monthly mean flow $(\sim 30 \mathrm{~m} 3 / \mathrm{s})$. However, under daily maximum flow condition, salinity intrusion points were pushed further downstream by about $900 \mathrm{~m}$ (on a 15-day average) compared to the highest monthly mean flow (1440 m3/s). Correspondingly, inundation area was increased by $14 \%$; average water depth increased by $0.3 \mathrm{~m}$ and salinity dropped about $1.5 \mathrm{ppt}$ in the inundated area. 

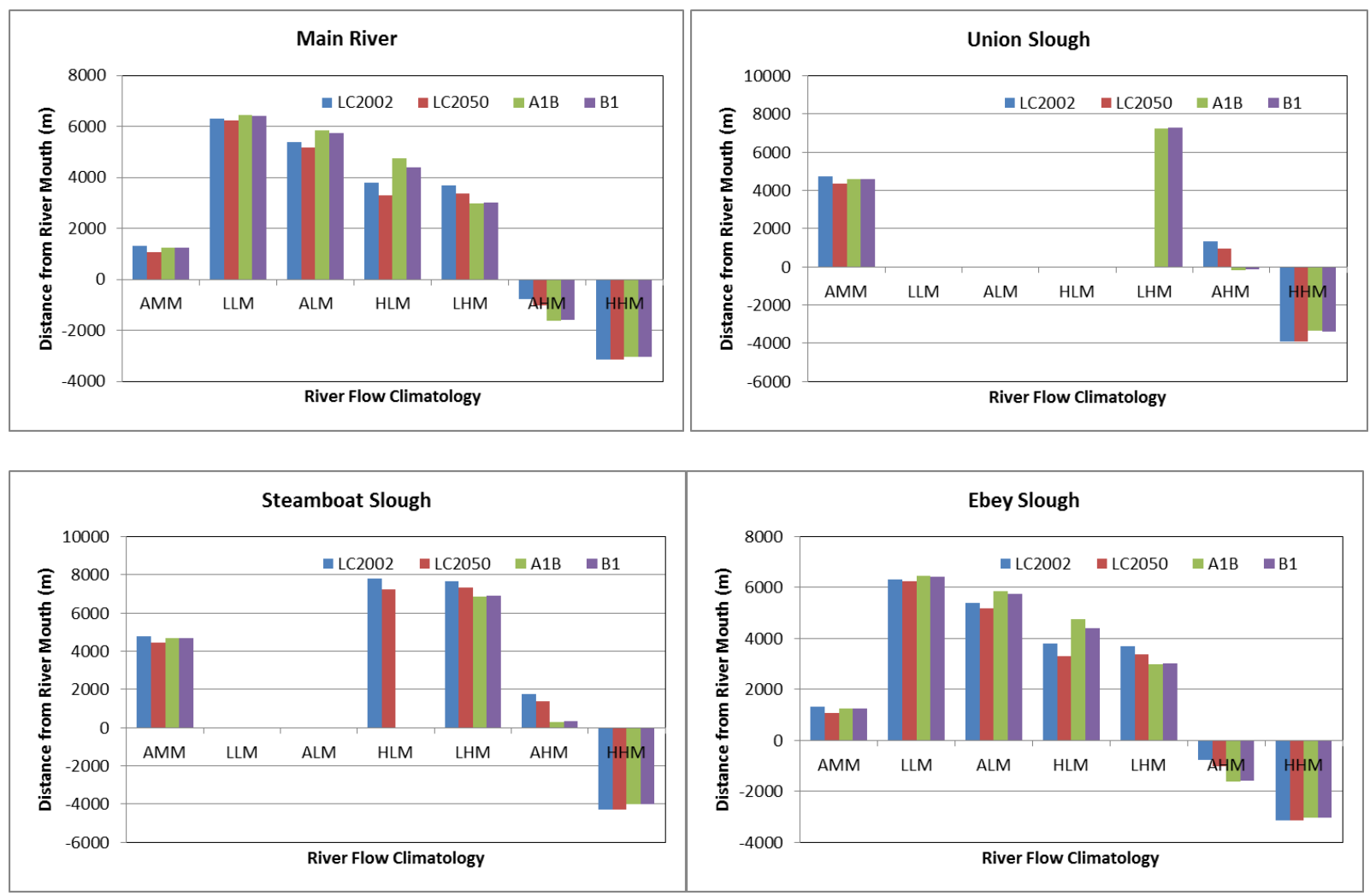

Figure II - 17. Salinity intrusion points in the distributaries of Snohomish River Estuary under climate change (A1B and B1) and LULC scenarios

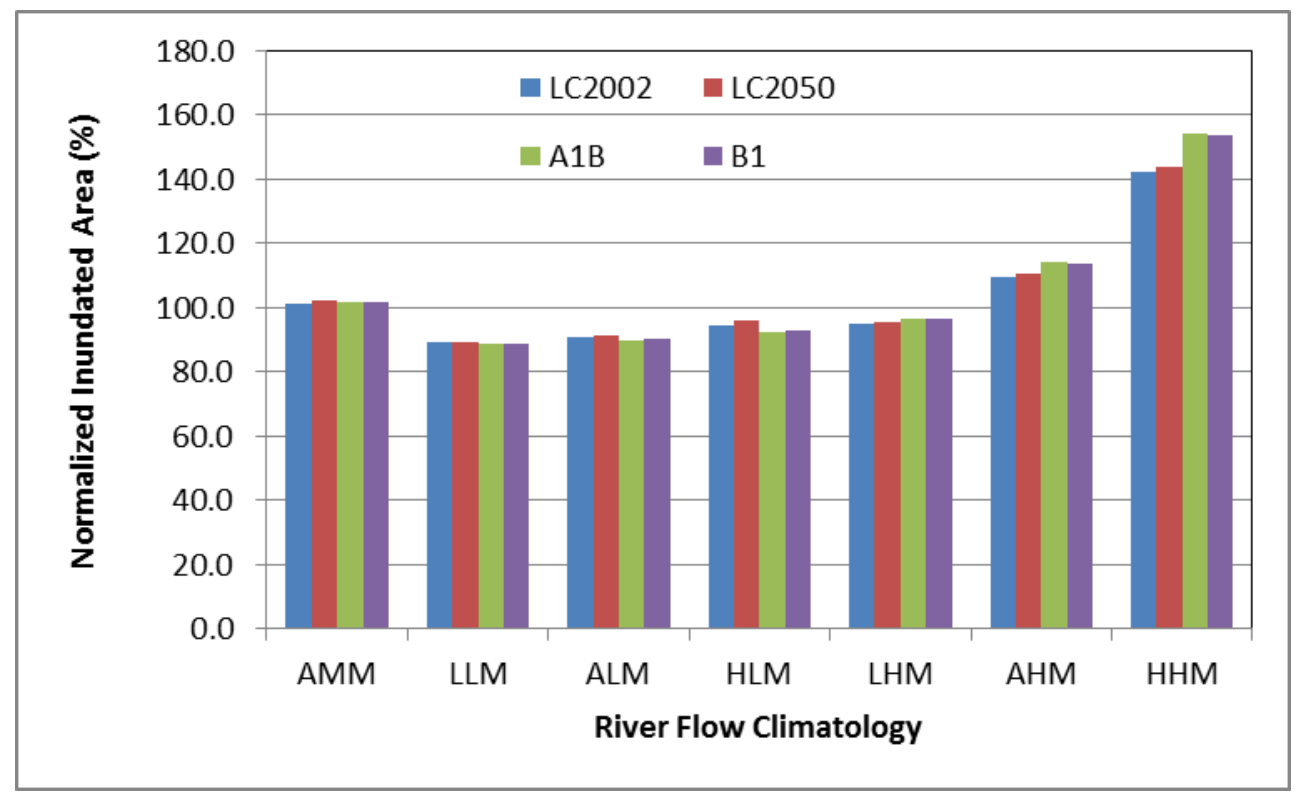

Figure II - 18. Normalized Inundated Area in the Snohomish River Estuary under climate change (A1B and B1) and LULC scenarios 


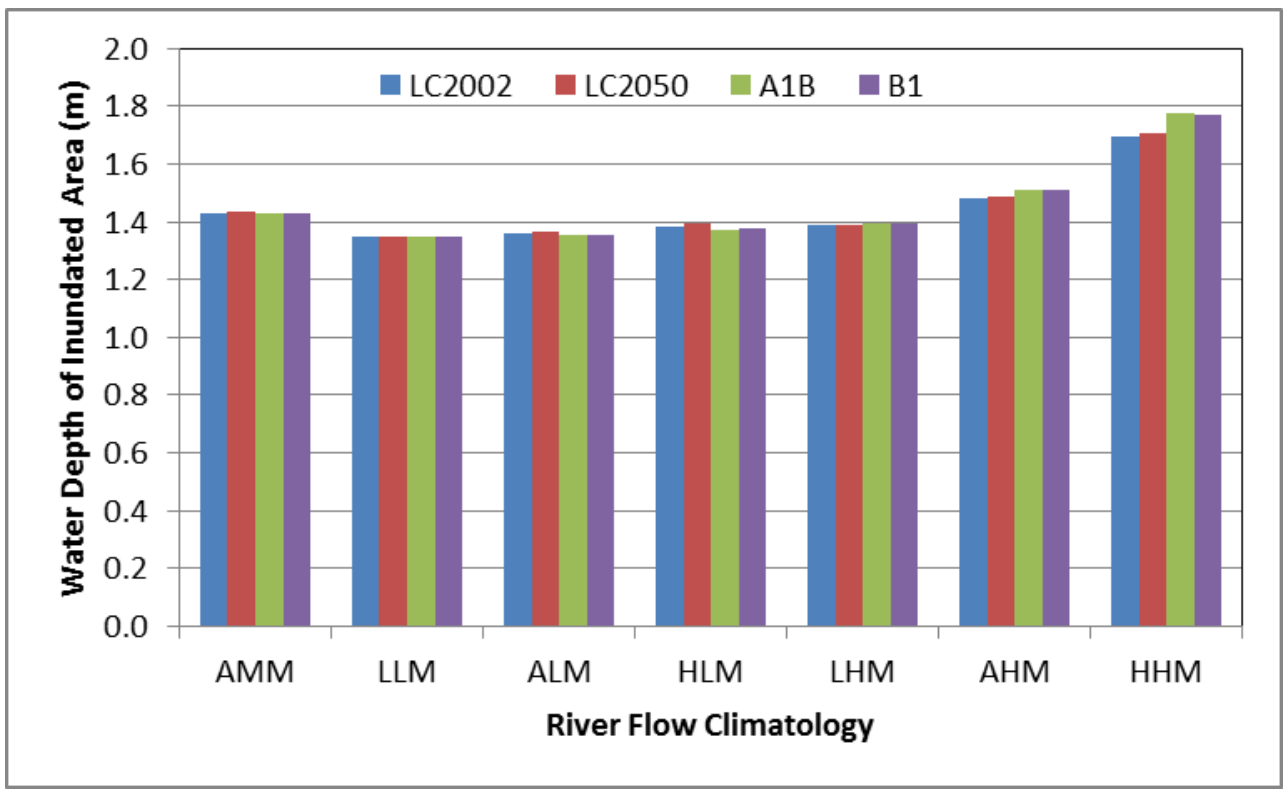

Figure II - 19. Average water depth in the inundated area of Snohomish River Estuary under climate change (A1B and B1) and LULC scenarios

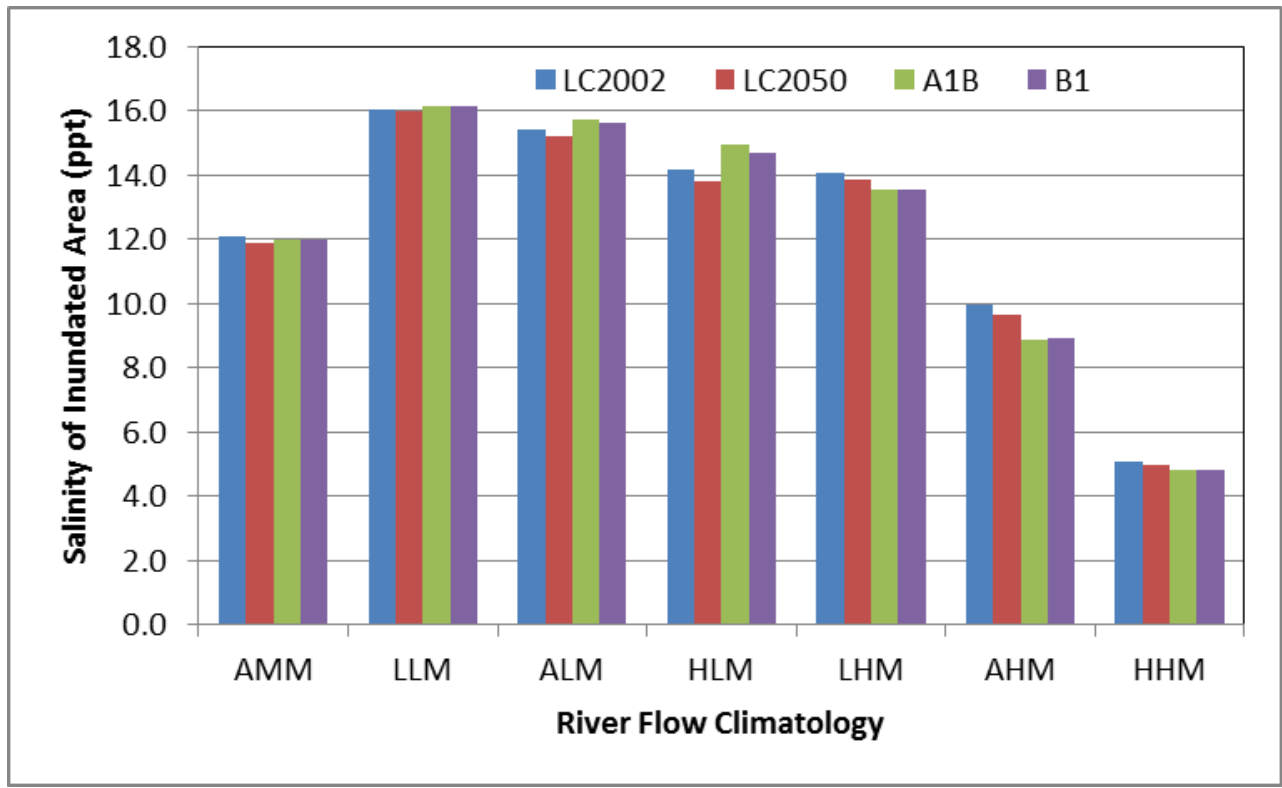

Figure II - 20. Average salinity in the inundated area of Snohomish River Estuary under climate change (A1B and B1) and LULC scenarios

\section{II.2.5 Estuarine Response to Sea-level Rise Scenarios}

Various factors, including changes in wind patterns, gravitational and deformational effects of modern land ice melting, and vertical land motion, contribute to the relative sea-level rise along the U.S. West Coast. Recently, the National Research Council (NRC) conducted a 
detailed analysis of sea-level rise trends along the U.S. West Coast based on IPCC global sealevel rise projections and relevant data and model results, as well as recently published research results (NRC 2012). The projected relative sea-level rise at Seattle contributed by all the factors is $0.166 \mathrm{~m}$ with an uncertainty of $\pm 0.105 \mathrm{~m}$ for the year 2050 . The relative sea-level rise will rapidly increase to $0.618 \mathrm{~m}$ with an uncertainty of $\pm 0.293 \mathrm{~m}$ by the end of the century. To look at the potentially large effects of sea-level rise on estuarine hydrodynamics, three sea-level rise projections, $0.325 \mathrm{~m}, 0.618 \mathrm{~m}$ and $0.911 \mathrm{~m}$, based on $0.618 \mathrm{~m}$ sea-level rise with an uncertainty of $\pm 0.293 \mathrm{~m}$ by the end of the century, were considered in this study. Sea-level rise scenarios were simulated under the low, mean and high monthly average river flow conditions $(30,270$, and $810 \mathrm{~m}^{3} / \mathrm{s}$ ). Therefore, a total of nine model runs were conducted to evaluate the effect of sealevel rise on the hydrodynamics in the Snohomish River Estuary.

Model outputs of salinity intrusion points in the main-stem of the Snohomish River, inundated area, average water depth and salinity of inundated area are provided in Figure II - 21 to Figure II - 24. It is seen that all variables, including salinity intrusion points, normalized inundated area, average water depth and salinity of the inundated area, respond to the effect of sea level rise linearly.

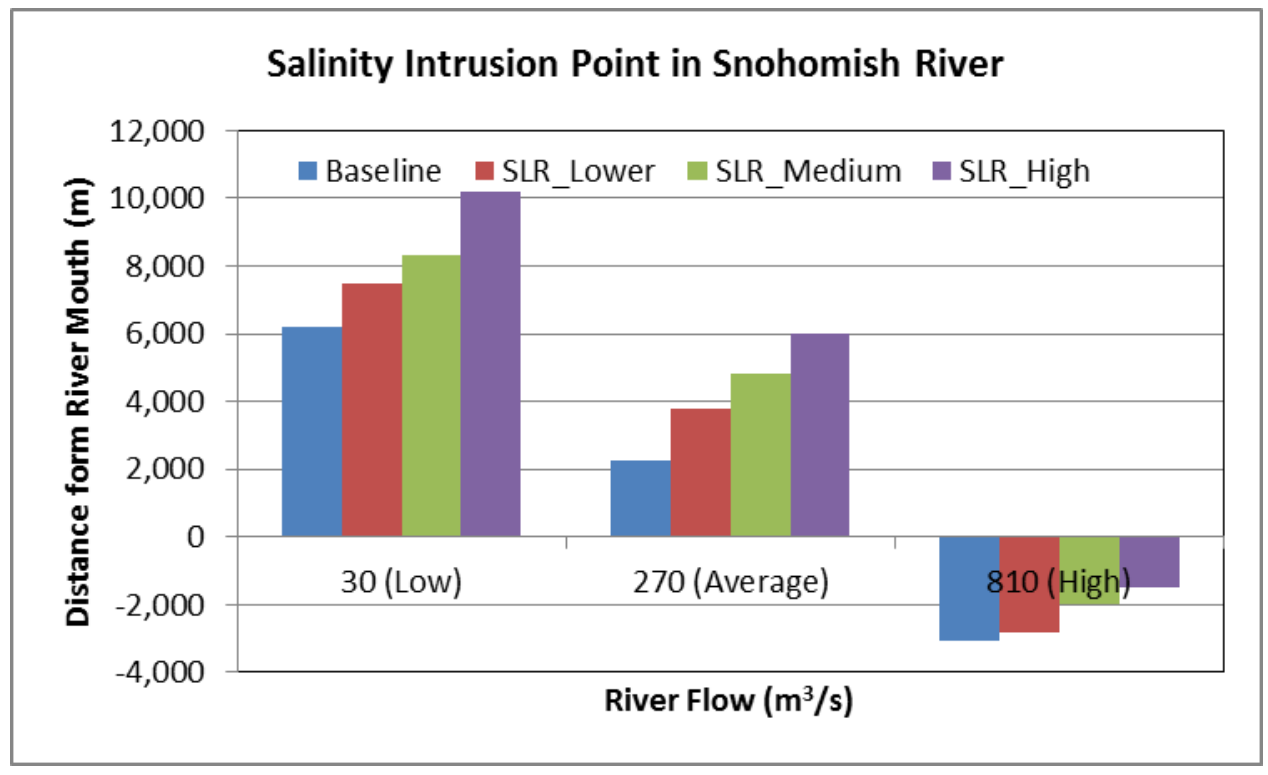

Figure II - 21. Salinity intrusion points in the Snohomish River Estuary as a result of sea-level rise under historical lowest, average and highest monthly river flow conditions 


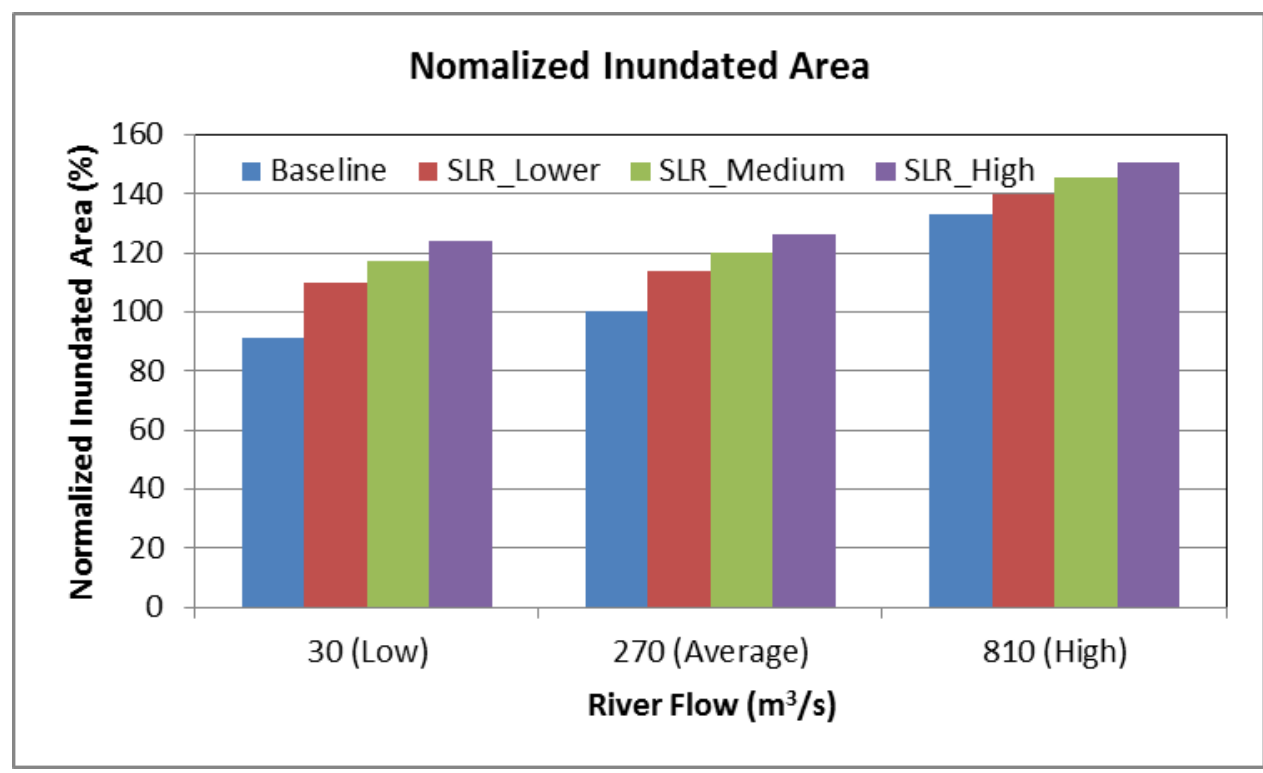

Figure II - 22. Normalized inundation area in the Snohomish River Estuary as a result of sealevel rise under historical lowest, average and highest monthly river flow conditions

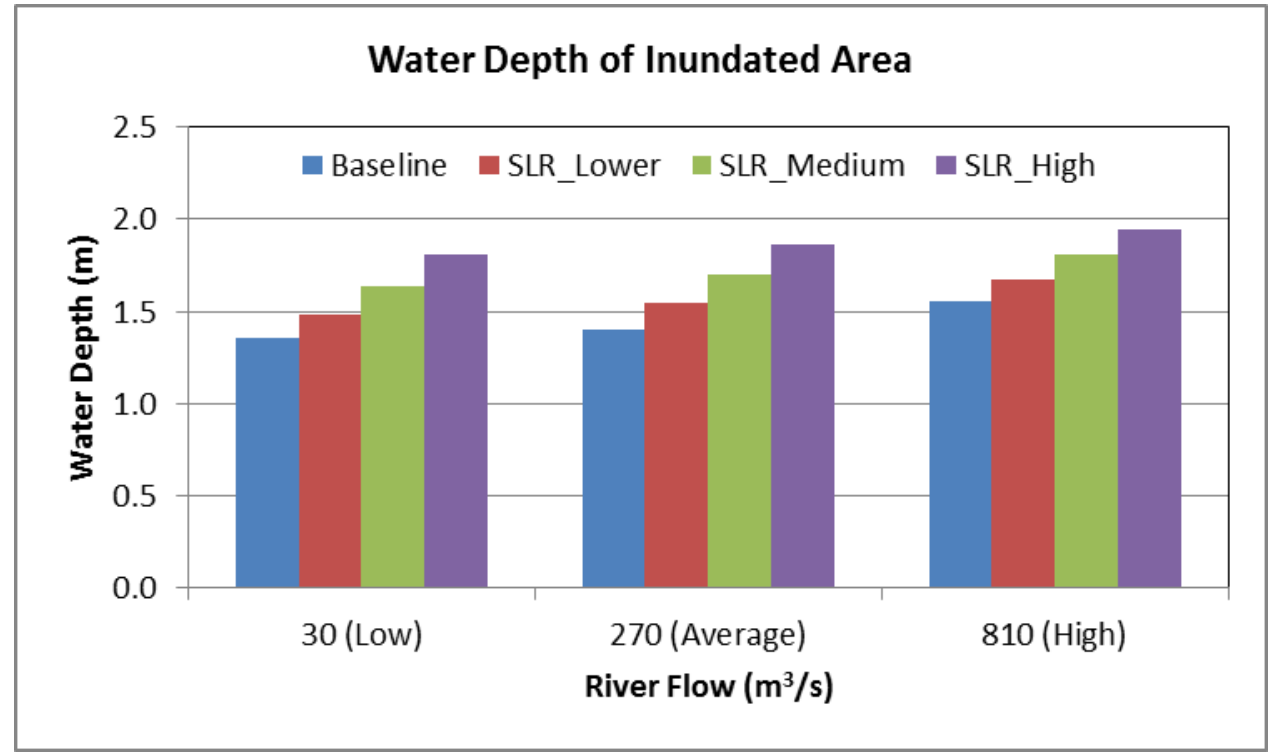

Figure II - 23. Average water depth of inundated area in the Snohomish River Estuary as a result of sea-level rise under historical lowest, average and highest monthly river flow conditions 


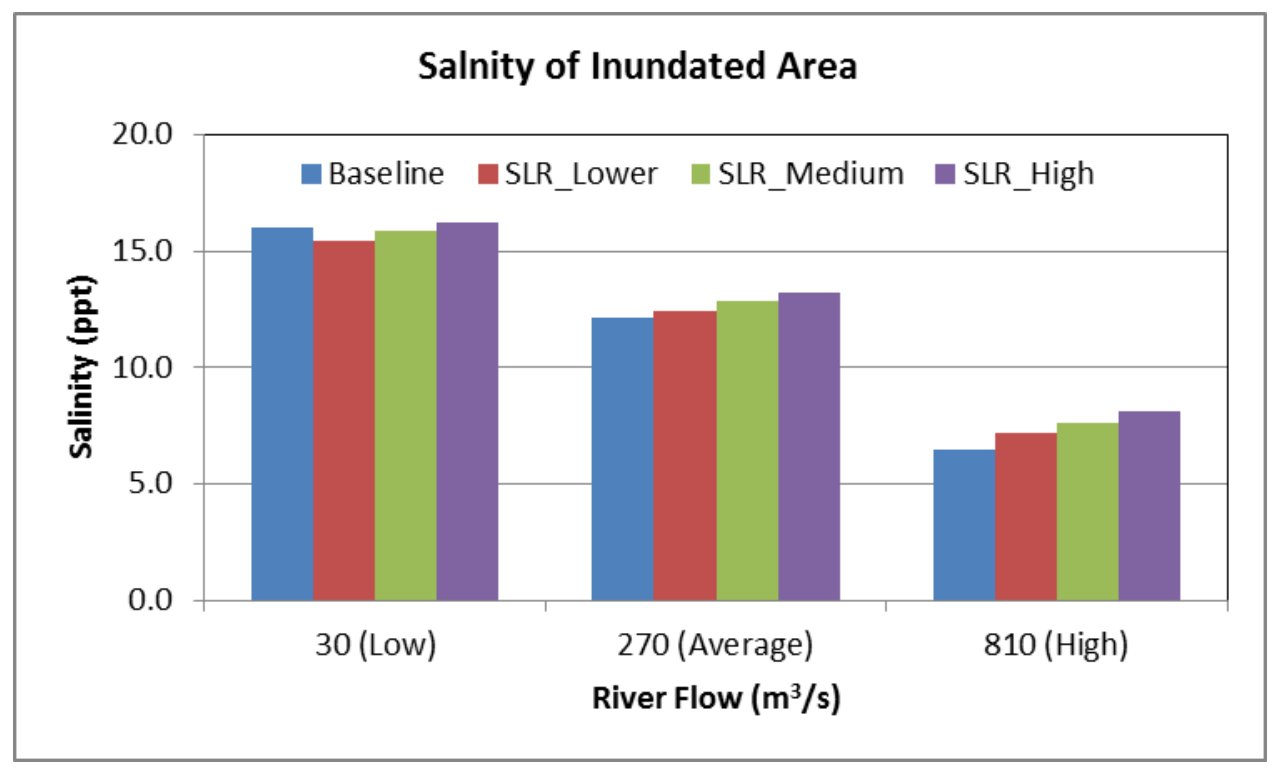

Figure II - 24. Average salinity of inundated area in the Snohomish River Estuary as a result of sea-level rise under historical lowest, average and highest monthly river flow conditions

\section{II.2.6 Simulation of Fecal Coliform Fate and Transport}

Fecal coliform contamination in the estuarine water is often caused by stormwater runoff due to urban development and poor stormwater management. In this study, a test model simulation was conducted to demonstrate the model capability of simulating the fate and transport of fecal coliform discharge into the Snohomish River. The City of Everett owns several stormwater outfalls that discharge to the Port Gardner of the Snohomish River. In the fecal coliform model setup, a constant concentration of $100 \mathrm{MPN} / \mathrm{L}$ was specified as a point source discharge. A decay rate of 1.0 was assumed and a settling velocity of $0.00001 \mathrm{~m} / \mathrm{s}$ for fecal coliform was specified. The model was run with normal conditions and a mean river flow of $270 \mathrm{~m} 3 / \mathrm{s}$. Surface concentrations of fecal coliform in Port Gardner in the Snohomish River Estuary at flood and ebb tides are shown in Figure II - 25. Preliminary model results indicated that the plume of fecal coliform discharged from City of Everett's outfall is diluted quickly once it is transported out of the estuary to Possession Sound, with little likelihood of retaining significant concentrations in Port Gardner Bay. 


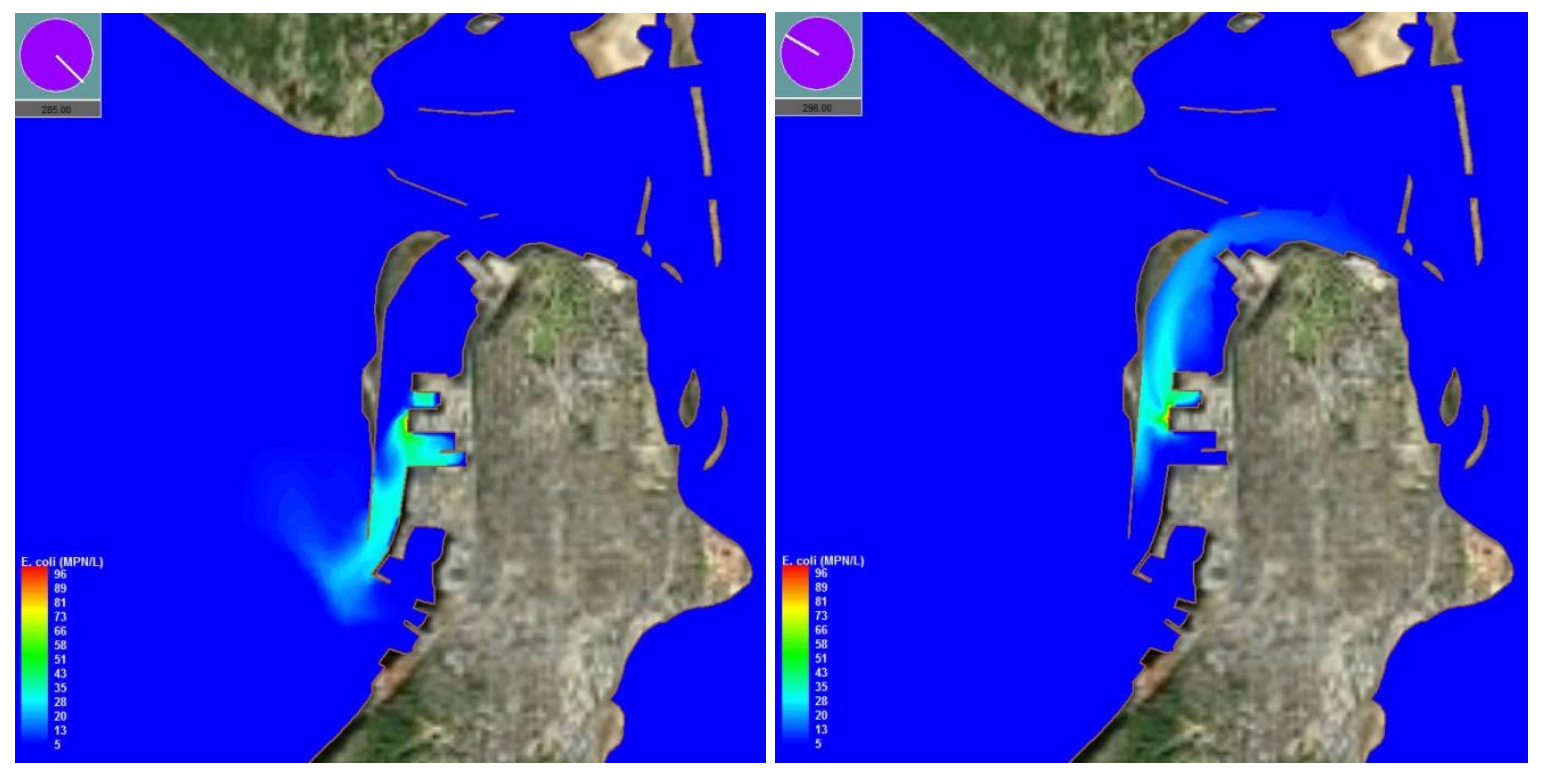

Figure II - 25. Surface concentration of fecal coliform in Port Gardner of Snohomish River Estuary at ebb tide (left) and flood tide (right) 


\section{II.3 Conclusions}

To better understand the hydrodynamic response to the change of river flow in the Snohomish River Estuary, a high resolution estuarine hydrodynamic model was developed for the Snohomish River Estuary using an unstructured-grid finite volume coastal ocean model (FVCOM). A series of model runs were conducted to simulate the hydrodynamics in the Snohomish River Estuary and its responses to a full range of river flows from lowest monthly flow to highest monthly flow. A set of parameters that are important to nearshore habitat and salmon migration, such as salinity intrusion points, inundation area, water depth and salinity of the inundated area, are calculated based on the model results. Regression analysis was conducted to establish the relationship between these parameters and the river flow.

Model results suggested that the salinity intrusion points in the distributaries of Snohomish River Estuary are a nonlinear function of river flow, especially in the range of low flow to medium flow. The gradient of salinity intrusion point in low flow condition is higher than that in the high flow condition. Salinity intrusion point does not exist in Union Slough and Steamboat Slough when river flow is smaller than $150 \mathrm{~m}^{3} / \mathrm{s}$ and $100 \mathrm{~m}^{3} / \mathrm{s}$, respectively. Significant high flows were needed to push the salinity intrusion point to the mouth of the distributaries, i.e., 400, 562, 597 and $666 \mathrm{~m}^{3} / \mathrm{s}$ for Snohomish River main river, Union Slough, Steamboat Slough and Ebey Slough, respectively.

Normalized inundated area, water depth and salinity of the inundated area in the Snohomish River Estuary were also analyzed as a function of river flow. With the exception of salinity, which follows a second-order polynomial relationship with river flow, other parameters are linearly proportional to the river flow. The average water depth in the inundated area is small and varies from roughly 1.3 to $1.7 \mathrm{~m}$ on an average time scale of the spring-neap tidal cycle. Normalized inundation area changes significantly as a function of river, ranging from -10\% for the low flow condition to as high as $50 \%$ for high flow conditions with respect to the mean flow of $270 \mathrm{~m}^{3} / \mathrm{s}$. Average salinity in the inundated area also varies significantly, from $16 \mathrm{ppt}$ for low flow condition to about $4 \mathrm{ppt}$ for high flow condition.

Regression analysis was conducted based on model results to develop predictive formulas for salinity intrusion points, inundated areas, average water depth and salinity of the inundated area as a function of river flow. These formulas were further used to estimate the hydrodynamics responses to river flows under climate change and LULC conditions that were simulated using DHSVM. Model results indicated that LULC scenarios show a strong impact on the estuarine hydrodynamics in low flow to mean flow conditions. In high river flow condition, climate change scenarios have a greater impact, especially on the inundated area in the estuary. Over all, average water depth of the inundated area is not very sensitive to climate change and LULC scenarios, except for very high flow conditions (e.g., $>800 \mathrm{~m}^{3} / \mathrm{s}$ ). On the other hand, average 
salinity in the inundated area is sensitive to river flow, especially for low to mean flow conditions.

Model results for sea-level rise scenarios suggested that sea-level rise will have significant impact on salinity intrusion points. As a result of sea-level rise, salinity intrusion points in the Snohomish River Estuary will move much further upstream. Consequently, sea-level rise will also cause an increase in inundated area, average water depth and salinity of inundated area.

Although the scientific findings of this study were derived from model results specifically for the Snohomish River Estuary, the methodology used in this study can be applied to other estuarine system. Similar regression formulas for the neashore habitat parameters can be developed and serve as an efficient management tool to provide vital hydrodynamic information and guidance for water management in the estuarine system. 


\section{II.4 References}

Chen C, H Liu, and RC Beardsley. 2003. "An unstructured, finite-volume, three-dimensional, primitive equation ocean model: application to coastal ocean and estuaries." Journal of Atmospheric Oceanic Technology 20:159-186.

Chen, C., Z. Lai, R. C. Beardsley, Q. Xu, H. Lin and N. T. Viet, 2012. Current separation and upwelling over the southeast shelf of Vietnam in the South China Sea. J. Geophys. Res., 117, C03033, doi: 10.1029/2011JC007150

Dukhovskoy, D.S. and Morey, S.L. 2011. Simulation of the Hurricane Dennis storm surge and considerations for vertical resolution. Natural Hazards, 58, 511-540

Greene, C.M., Beechie, T.J., 2004. Consequences of potential density-dependent mechanisms on recovery of ocean-type chinook salmon Onchorhynchus tshawytscha. Can. J. Fish. Aquat. Sci. $61,590-602$.

National Research Council (NRC). 2012. Sea-Level Rise for the Coasts of California, Oregon, and Washington: Past, Present and Future. Committee on Sea-level Rise in California, Oregon, and Washington. Board on Earth Sciences and Resources and Ocean Studies Board. The National Academies Press, Washington, D.C.

Rego, J.L. and Li, C. 2010, Storm surge propagation in Galveston Bay during Hurricane Ike. Journal of Marine Systems 82 (4) , pp. 265-279

Scheuerell, M.D., Hilborn, R., Ruckelshaus, R.M., Bartz, K.K., Lagueux, K.M., Haas, A., Rawson, K., 2006. The shiraz model: a tool for incorporating anthropogenic effects and fishhabitat relationship in conservation planning. Can. J. Fish. Aquat. Sci. 63, 1596-1607.

Xing J., A. M. Davies and E. Jones. 2012. Influence of sea surface wind wave turbulence upon wind induced circulation, tide-surge interaction and bed stress. Ocean Dynamics, 62, 1017-2042

Yang, Z., and T. Khangaonkar, 2009. Modeling Tidal Circulation and Stratification in Skagit River Estuary Using an Unstructured Grid Ocean Model. Ocean Modelling, 28, 34-49. doi: 10.1016/j.ocemod.2008.07.004.

Yang, Z., T. Khangaonkar, M. Calvi, K. Nelson, 2010. Simulation of Cumulative Effects of Nearshore Restoration Projects on Estuarine Hydrodynamics. Ecol. Model. 221, 969-977. doi: 10.1016/j.ecolmodel.2008.12.006

Yang, Z. T. Wang T. Khangaonkar and S. Breithaupt, 2012. Integrated Modeling of Flood Flows and Tidal Hydrodynamics over a Coastal Floodplain. Journal of Environmental Fluid Mechanics. 12, 63-80. DOI: 10.1007/s10652-011-9214-3 
Yang, Z. and T. Wang, 2013. Tidal Residual Eddies and Their Effect on Water Exchange in Puget Sound. Ocean Dynamics, 63, 995-1009. DOI: 10.1007/s10236-013-0635-Z

Zhao, L., Chen, C., Cowles, G., 2006. Tidal flushing and eddy formation in Mount Hope Bay and Narragansett Bay: an application of FVCOM. J. Geophys. Res., 111, C10015, doi:10.1029/2005JC003135. 


\title{
Appendix III. Integration of Models for Snohomish Basin: IWRMS
}

\author{
R. Taira
}




\section{Contents}

Appendix III . Integration of Models for Snohomish Basin: IWRMS ........................................ 1

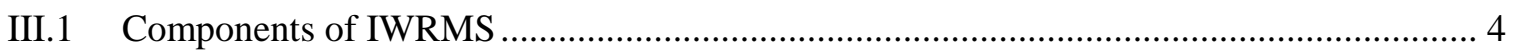

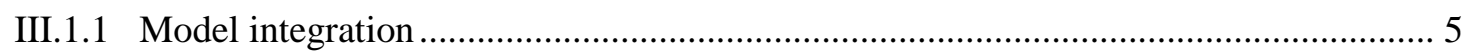

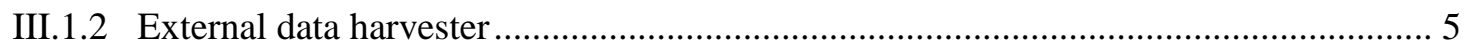

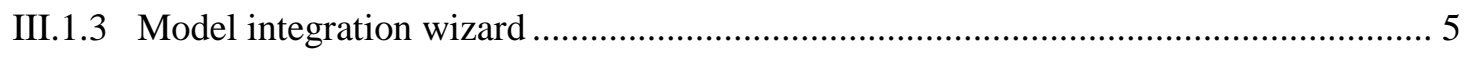

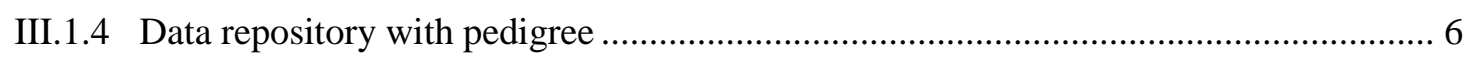

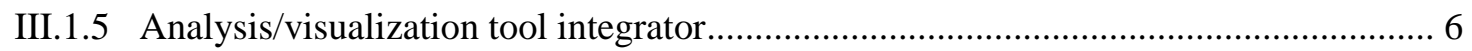

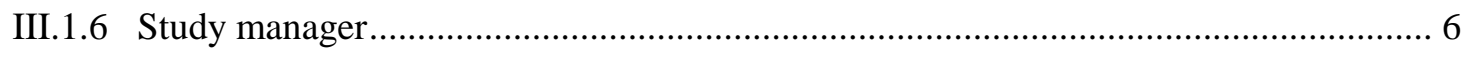

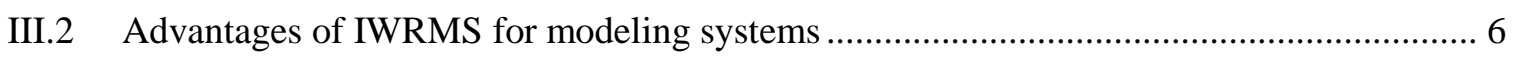

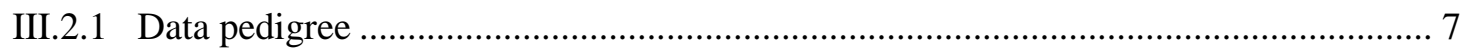

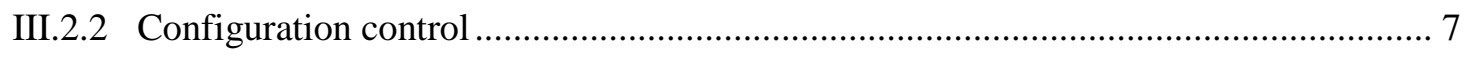

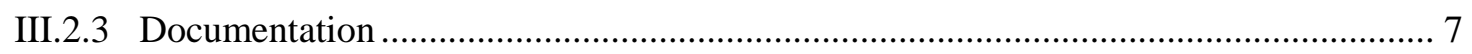

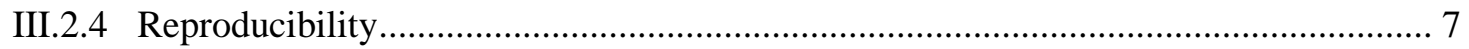

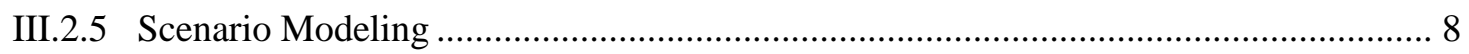

III.3 IWRMS modifications for Snow Caps to White Caps ...................................................... 8

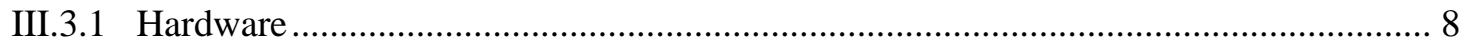

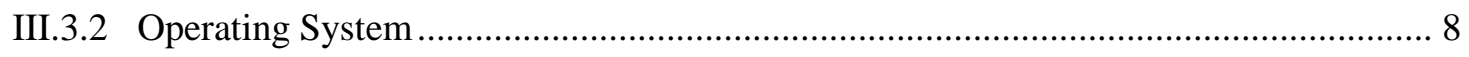

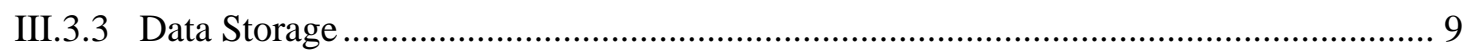

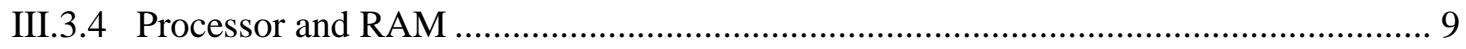

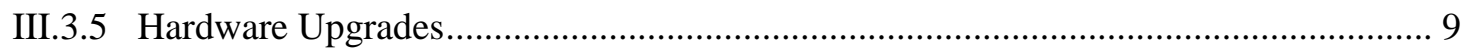

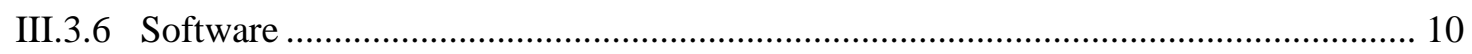

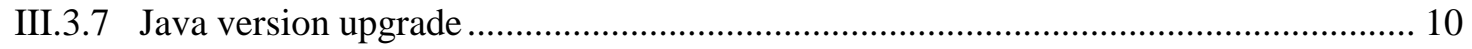

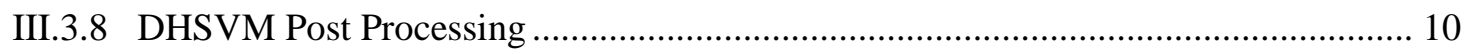

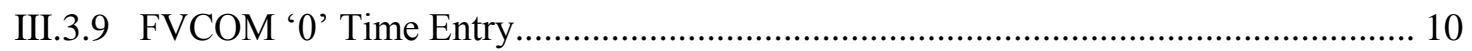

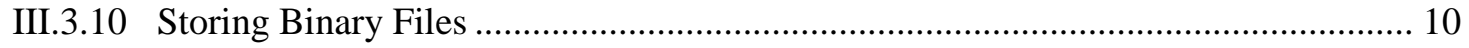

III.3.11 Exporting Model Output Data........................................................................ 11

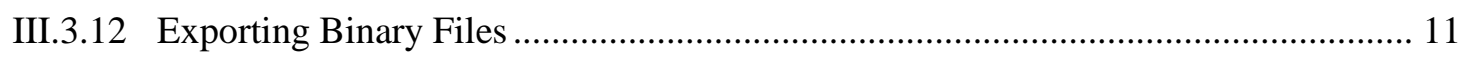

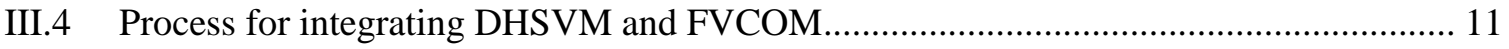

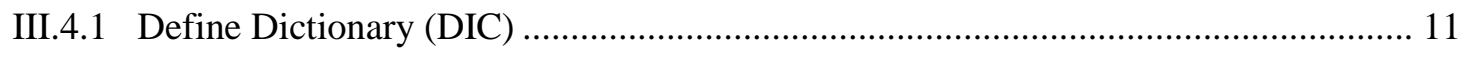

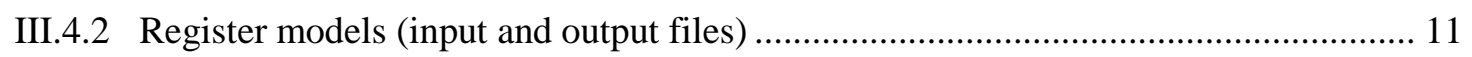

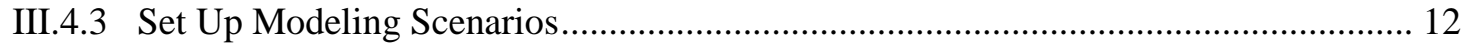

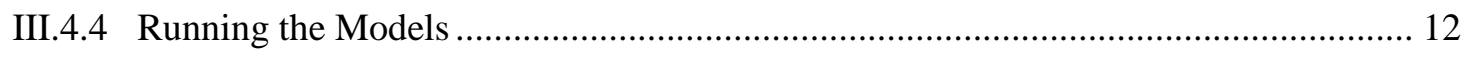

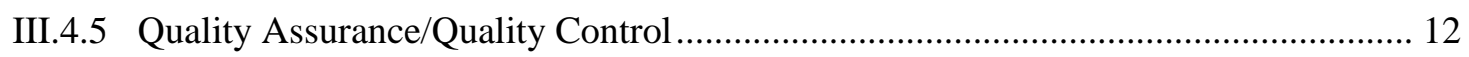




\section{Tables}

Table III - 1. The server upgrades are summarized in the following table:.................................... 9

Table III - 2. The computer node purchased are summarized in the following table:..................... 10 


\section{Appendix III: Introduction}

This project involved the modeling of water resources in the Snohomish Basin from their source in the mountains through surface water bodies down to the estuary. Two distinct models were used to accomplish this: The Distributed Hydrology Soils and Vegetation Model (DHSVM) was used to model the snowpack/snowmelt and watersheds and the Finite Volume Coastal Ocean Model (FVCOM) was used to model the floodplains and estuary. Using a traditional modeling approach, the two models would have been integrated as follows:

- DHSVM would be set up, calibrated, and executed

- DHSVM output data would be post processed such that it could be used as input for FVCOM

- FVCOM would be set up (including the input data from DHSVM), calibrated, and executed

This approach is functionally efficient and adequate to achieve completion of a modeling assessment; however, it does not enforce other important aspects of an assessment such as configuration control, documentation, and reproducibility. For this reason, the model integration component of this project was performed using the Integrated Water Resource Modeling System (IWRMS). The following sections will describe the IWRMS, how it was implemented, and will summarize the results of the model integration process. The interpretation of the modeling results will be addressed in a separate section.

\section{III.1 Components of IWRMS}

The IWRMS was developed by PNNL for the King County Department of Natural Resources and Parks (KC-DNRP). Its purpose is to provide an integrated modeling and data management capability to support scientific investigations and planning efforts in the Sammamish-Washington and Green-Duwamish watersheds. The system is a combination of hardware and software. The hardware consists of a primary server, eight computer nodes, external storage, uninterruptible power supplies, a tape backup system, and a console. All of this hardware resides in a single $42 \mathrm{U}$ server rack. The software is coded in Java, with the exception of the model integration component, and SQL Server that is used for data storage. For the model integration component, a pre-existing model integration software system called the Framework for Risk Analysis in Multimedia Environmental Systems (FRAMES) was used. FRAMES was developed by PNNL with sponsorship from U.S. DOE, U.S. EPA, U.S. NRC, and the U.S. Army Corps of Engineers Engineer Research and Development Center (ERDC).

While the IWRMS was developed for the purpose of performing water resource modeling, it is important to note that it is not restricted to this. The IWRMS is really a 
generic system that manages passing of data, model execution, and data storage. The models in IWRMS are black boxes and thus it lends itself well to the integration of different models and model types. The IWRMS is also not geographically constrained. The onus is on the modelers to accurately model the geographic region of interest through which their models are set up. The models are black boxes to the system; the IWRMS is responsible for accurately passing data from one model to the next, in the required formats. It is this characteristic that allows the system, which was developed for use in King County watershed basins, to be applied in Snohomish County or to any other region.

In addition to the modeling and data management functionalities, the system is also intended to provide an environment for water resource management in which the target user population includes hydrologists, water quality planners, and management. Thus, the IWRMS architecture incorporates additional functionality to address the needs of each of these user levels in conducting scientific studies. The following are brief descriptions of the IWRMS system components:

\section{III.1.1 Model integration}

As noted previously, FRAMES is employed as the underlying model integration component. The FRAMES software provides a platform for the integration of disparate models. FRAMES employs Dynamic Link Libraries (DLLs) to handle the passing of data between models and to enforce correct formatting. FRAMES was designed to pass data as flat ASCII text files, but was modified during IWRMS development to send and retrieve data from a SQL server.

\section{III.1.2 External data harvester}

Environmental models require input data from multiple internal and external sources that include, but are not limited to, stream and rainfall gauge data, metrological data, habitat data, and biological data. These data are retrieved from various source types (e.g., http, ftp, and databases) and with various frequencies (e.g., one-time, daily, and monthly). Retrieving and reformatting data is extremely time-consuming and expensive. The External Data Harvester enables users to set up one-time or scheduled recurring extractions of data from data sources and to store the parsed data in SQL tables in the Data Repository. Harvested data can then be checked out to be QA/QC'd or it can be used directly by models in the system.

\section{III.1.3 Model integration wizard}

Integrating models typically requires the development of unique software applications to transform each model's input and output formats into formats that can be passed between models. With the Model Integration Wizard, such model-specific data transformation software is not required. Instead, modelers enter sample (or template) 
input and output files and graphically map them to the user-defined model to model boundary data specifications. The Wizard then uses these mappings to parse model output files and store the data associated with the data specification; the Wizard will also apply the mapping to generate model input files by substituting new data into the template input files.

\section{III.1.4 Data repository with pedigree}

The Data Repository is the central storage facility for data that is imported into and produced within the IWRMS, as well as the storage for models integrated into the system. The Data Repository is comprised of a SQL database and acts as the data store for all elements in the system including: data transformations, data specifications, modeling scenarios, registered models, data sets (either from data sources or model run results), and reports. Each element within the system will have a pedigree that uniquely identifies it, its source, and the processes which produced it. This identification is vital to results tracking and reproducibility.

\section{III.1.5 Analysis/visualization tool integrator}

There are many existing data analysis and visualization tools (e.g., ArcGIS, MatLab, and M.S. Excel) that can be used to evaluate and communicate modeling results. Rather than create new ones, the IWRMS has utilities that allow users to port modeling data in flat ASCII text formats to $3^{\text {rd }}$ party applications for analysis and/or visualization.

\section{III.1.6 Study manager}

The Study Manager provides a robust, usable human interface to the integrated modeling capability. Its user interface enables the user to specify modeling scenarios, search previously performed modeling studies, assign tasks, track work status, and provides other functionalities to facilitate interaction with the underlying models. Study Manager also has a Study Report feature that utilizes a customizable XML style sheet to produce a report. Each report summarizes a modeling study that includes the status of all tasks.

\section{III.2 Advantages of IWRMS for modeling systems}

The intent of the IWRMS is to facilitate the integration of models and the managing of data. However, this does not necessarily translate into simplifying a modeling task. Running a model standalone outside of the system will always be less complicated than within the IWRMS framework. Additionally if a model is complex and complicated to run outside the system, it will continue to be so inside the IWRMS. To an individual 
modeler, there will additional overhead in running their model in the IWRMS. The benefit of IWRMS is derived from the ease of integration among models and in the structuring of the processing, documenting, and storage of the results. Details of the primary benefits are presented below:

\section{III.2.1 Data pedigree}

IWRMS uses a concept called the Data Pedigree. Every piece of data associated with a modeling run is stored such that the modeling run can be reproduced identically in future. Data that are collected and pedigreed include: all model input data files; all model files tagged by version; model output files; model connection schemes; and model scenarios.

\section{III.2.2 Configuration control}

Models are registered in the IWRMS such that as a model run is carried out, the system tracks exactly which executable was used. This is particularly useful as modelers frequently "tweak" their modeling codes to add functionality or to fix bugs. In applying this method, there is never uncertainty as to which code created a set of modeling results, allowing for each run to be reproduced in minute detail.

\section{III.2.3 Documentation}

In addition to documenting all data sets and files used in a modeling scenario, the IWRMS requests descriptions for all data entered into the system. The Documentation system provides many opportunities for documenting components; however, it is up the users to provide the necessary detail. Obviously, the better the descriptions, the easier it will be to understand what steps were taken and what outcomes the modeling provides. Documentation might include:

- Details that describe a modeling scenario may be added, such that it will be searchable later.

- Details on model versions can be entered so that it is clear which version of a modeling code was used, and any details of that version.

- Documents can be attached to a model when it is integrated, so that detailed information can be provided on the modeling run itself.

- When a modeling scenario is set up through the Study Manager, documents can be attached to further describe the scenario. For instance, the report that describes and established a modeling scenario, and the final report that resulted from interpreting those modeling results could be attached.

\section{III.2.4 Reproducibility}

IWRMS uses this concept that ties together Data Pedigree, Configuration Control, and Documentation. IWRMS tracks all components necessary to reproduce any model 
runs completed within the system. The genesis of this feature was the need to ensure that details of modeling runs and ancillary data transcend the memories and records of individual staff, including the need to ensure continuity during staff turnover. IWRMS uses these features to enforce robust documentation to simplify complex modeling processes and ensure a structured approach.

\section{III.2.5 Scenario Modeling}

The IWRMS is an ideal environment for modeling various scenarios that examine changing variables and future casting. FRAMES was initially developed for modelers to integrate multiple disparate models, comparing outcomes that are likely to different outcomes. For example, a groundwater modeler might use a particular well-known source term model, however they may be two or more different groundwater transport models in common use. Using the IWRMS, a modeler might run one scenario with the source term model and groundwater model A; then run a second scenario with the same source term model set up using groundwater model B. By documenting the modeling runs the modeler can be assured that the differences in the output results is strictly associated with the groundwater model, and not due to other factors such as changes in source terms. Additionally, the IWRMS allows the user to enter descriptive information such that the differences between two model runs can be recorded.

\section{III.3 IWRMS modifications for Snow Caps to White Caps}

For the purposes of this project, hardware and software modifications were necessary. Hardware was purchased to meet the demands of the modeling activities including the particular operating systems (OS) that correspond to the models used; data storage capacity; processor speed; and RAM. Software modifications were needed to address model specific issues not encountered in the original IWRMS application. The following sections describe the hardware and software changes that were made.

\section{III.3.1 Hardware}

The original IWRMS hardware was purchased in 2005 and was sufficient for King County's modeling needs; however, it was not sufficient for the current application. The following are descriptions of specific deficiencies and how they were addressed:

\section{III.3.2 Operating System}

The IWRMS was developed specifically for a client that only utilized Windows based models. The IWRMS code, however, was written in Java, so that it would be extensible to other operating systems (OS). IWRMS computing resources at the start of this project operate on the Windows OS and are reserved for King County use. For the purposes of 
this project, both models have been run on the Linux OS. FVCOM operates on its own Linux cluster so no new hardware was needed to run it. The existing cluster could be linked to in order to execute model runs. DHSVM had no dedicated hardware; to address this lack, a compute node was purchased, the Linux OS installed and the node dedicated to DHSVM model runs.

\section{III.3.3 Data Storage}

The IWRMS was initially designed with 3 TB of storage, which was sufficient to hold the projected needs of the King County modelers. This capacity is designated for King County use so new data storage needed to be purchased. Initial estimates for FVCOM output were 200 GB per 1 year model run. DHSVM estimates were smaller; however, to be conservative 6 GB of storage in RAID 5 configuration (4.6 TB usable) was purchased.

\section{III.3.4 Processor and RAM}

As noted, the original hardware was purchased in 2005, so in order to optimize performance, the IWRMS server was upgraded to a $2.93 \mathrm{GHz}$ processor with $24 \mathrm{~GB}$ of RAM.

\section{III.3.5 Hardware Upgrades}

Table III - 1. The server upgrades are summarized in the following table:

\begin{tabular}{|l|c|}
\hline \multicolumn{1}{|c|}{ Description } & Quantity \\
\hline DELL - PowerEdge R710 Quad Core 2.66Ghz Rack Server (2U) * & 1 \\
\hline $\begin{array}{l}\text { DELL - CUSTOMIZE - Memory Upgrade NEW PowerEdge R610/R710 to 24GB } \\
\text { RDIMMS 1333Mhz (6x4GB) * }\end{array}$ & 1 \\
\hline $\begin{array}{l}\text { DELL - CUSTOMIZE - Raid - PowerEdge R610/R710 PERC 6/i SAS RAID } \\
\text { Controller (NEW) }\end{array}$ & 1 \\
\hline $\begin{array}{l}\text { DELL - CUSTOMIZE - Optical Drive - PowerEdge R610/710 DVD-RW Upgrade } \\
\text { NEW }\end{array}$ & 1 \\
\hline $\begin{array}{l}\text { DELL - CUSTOMIZE - Hard Drive - Upgrade NEW R710 from 146GB to 1TB 7.5K } \\
\text { Near Line SAS Drive }\end{array}$ & 5 \\
\hline $\begin{array}{l}\text { DELL - CUSTOMIZE - Hard Drive - Additional NEW 1TB 7.5K Near Line SAS } \\
\text { Drive * }\end{array}$ & 1 \\
\hline $\begin{array}{l}\text { DELL - CUSTOMIZE - CPU Upgrade NEW PowerEdge R610/R710 to (2) Six Core } \\
\text { Intel Xeon X5670, 2.93Ghz, 12M Cache Processors * }\end{array}$ \\
\hline
\end{tabular}


Table III - 2. The computer nodes purchased are summarized in the following table:

\begin{tabular}{|l|c|}
\hline \multicolumn{1}{|c|}{ Description } & Quantity \\
\hline DELL - PowerEdge R610 Quad Core 2.66Ghz Rack Server (1U) * & 1 \\
\hline $\begin{array}{l}\text { DELL - CUSTOMIZE - CPU Upgrade NEW PowerEdge R610/R710 to (2) Intel } \\
\text { Xeon X5650, 2.66Ghz, 12M Cache Processors * }\end{array}$ & 1 \\
\hline $\begin{array}{l}\text { DELL - CUSTOMIZE - Hard Drive - Upgrade NEW R610 from 146GB to 300GB } \\
\text { SAS Drive }\end{array}$ & 1 \\
\hline
\end{tabular}

\section{III.3.6 Software}

Software modifications were needed to address Linux compatibility issues, and model issues that were specific to integrating DHSVM and FVCOM, as summarized in the following sections.

\section{III.3.7 Java version upgrade}

It was necessary to upgrade to a newer version of Java in order to stay current with security issues and improvements. In doing so, it was discovered that some of our calls had been depricated and thus some code had to be modified to use more current calls.

\section{III.3.8 DHSVM Post Processing}

FVCOM requires a row count for temporal data in its control file. The IWRMS writes the input file but did not have the functionality to write a line with the row count. A modification was made to include a row count for the DHSVM output data so that it could be captured and written into the FVCOM input data file.

\section{III.3.9 FVCOM '0’ Time Entry}

It was discovered that FVCOM requires a zero time entry in its input file. DHSVM does not output a result for time zero; a modification was made to write in the time zero entry into the FVCOM input file.

\section{III.3.10 Storing Binary Files}

IWRMS was initially designed to store only specific parameters from output files in its data repository. The IWRMS can parse ASCII or NetCDF output files to retrieve specific 'mapped' parameters for storage. FVCOM writes output files in binary format, which the IWRMS cannot parse. For this project, it was decided that the system would store the entire output binary files and that other existing tools could later be used to access the file contents. Modifications were made to enable this storing of binary files through bulk loading the files into the database 


\section{III.3.11 Exporting Model Output Data}

The IWRMS had the functionality to export data; however, this was not used extensively and in testing it was found that some changes were needed. These modifications were made, so that it the system is better able to export data into text formats.

\section{III.3.12 Exporting Binary Files}

IWRMS was not initially designed to work with binary files. A modification was needed to be able to export binary files.

\section{III.4 Process for integrating DHSVM and FVCOM}

The process for integrating DHSVM and FVCOM within the IWRMS followed a standard procedure developed IWRMS. Aside from the software modifications detailed above, no user process changes were needed. Key steps include developing a data dictionary; registering models; modeling scenarios; and running the models. Each steps is described here.

\section{III.4.1 Define Dictionary (DIC)}

In this step, the spatial boundary conditions between the two models were defined. Basically, this is the agreement on which forcing data will be passed dynamically from DHSVM to FVCOM through the system. All other parameters data required by FVCOM is provided through static files registered into the IWRMS system during model registration. The list of variables output by DHSVM and the list of FVCOM input variables were obtained. An initial set of transferable data was developed but it was reduced to just time and volumetric flow rate of water as a proof of concept. The Dictionary Editor was then used to create a Dictionary (DIC) file, which specified the boundary data between DHSVM and FVCOM. An input DIC file was not needed for DHSVM because the forcing dataset was generated independently and registered with the model.

\section{III.4.2 Register models (input and output files)}

The IWRMS employs graphical user interfaces for all processes in the system. The Model Integration Manager (MIM) component was used to step through the process of registering the models into the system. The primary MIM steps are as follows:

- Upload the executable file for the model as well as the input file or files;

- Upload any other prescribed parameter and input files; 
- Enter in information associated with the model description (revision, compiler, etc...);

- Enter command line arguments required by the model at execution;

- Upload a template output file or files;

- Specify an output DIC file;

- Graphically map parameters in output file to parameters in DIC file;

- Specify an input DIC file; and

- Graphically map parameters in the input file to parameters in the DIC file.

Note that the same DIC file is used to map the variables from DHSVM output file as well as to map the input variables into FVCOM input file.

\section{III.4.3 Set Up Modeling Scenarios}

Once a DIC file has been created and the models have been registered into the system, the modeling scenario can be defined with the FRAMES component of the IWRMS. Using the Simulation Editor, icons representing the two models are added to a workspace. The models are then selected for each icon. A line is drawn to indicate the direction of data flow (i.e., from DHSVM to FVCOM).

\section{III.4.4 Running the Models}

The models are executed by clicking on the model icons. Order of model execution is from upstream to downstream following the direction of the arrow connecting the icons. Note that the Simulation Editor resides on the main server, but the models execute on separate computer nodes. In this case, DHSVM runs on the Linux compute node and FVCOM runs on its dedicated cluster. The IWRMS system manages the distributing of model executions and the passing of data to and from the computer nodes and storage and retrieval of data from the data repository.

\section{III.4.5 Quality Assurance/Quality Control}

The models were integrated together using the IWRMS as described above. A quality check was performed to ensure that results from the simulation executed inside and outside of the IWRMS framework were identical. This provided confirmation that the automated processes performed by the IWRMS accurately passed data between the two models. 


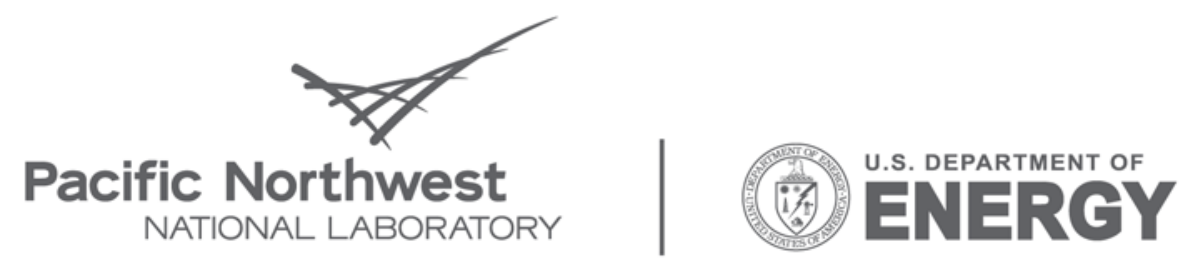

Proudly Operated by Battelle Since 1965

902 Battelle Boulevard

P.O. Box 999

Richland, WA 99352

1-888-375-PNNL (7665)

www.pnl.gov 